UNIVERSIDADE DE SÃO PAULO

FACULDADE DE FILOSOFIA, LETRAS E CIÊNCIAS HUMANAS DEPARTAMENTO DE LETRAS CLÁSSICAS E VERNÁCULAS

PROGRAMA DE PÓS-GRADUAÇÃO EM FILOLOGIA E LÍNGUA PORTUGUESA

CAROLINA FERNANDEZ ACHUTTI

MEMÓRIAS DO OUTRO E SUA SINGULARIDADE: NARRATIVA AUTOBIOGRÁFICA NO ENSINO FUNDAMENTAL - ANOS FINAIS

VERSÃO CORRIGIDA

São Paulo

2018 


\author{
UNIVERSIDADE DE SÃO PAULO \\ FACULDADE DE FILOSOFIA, LETRAS E CIÊNCIAS HUMANAS \\ DEPARTAMENTO DE LETRAS CLÁSSICAS E VERNÁCULAS \\ PROGRAMA DE PÓS-GRADUAÇÃO EM FILOLOGIA E LÍNGUA PORTUGUESA
}

CAROLINA FERNANDEZ ACHUTTI

\title{
MEMÓRIAS DO OUTRO E SUA SINGULARIDADE: NARRATIVA AUTOBIOGRÁFICA NO ENSINO FUNDAMENTAL - ANOS FINAIS
}

VERSÃO CORRIGIDA

Dissertação apresentada ao Programa de Pós-Graduação em Filologia e Língua Portuguesa, do Departamento de Letras Clássicas e Vernáculas da Faculdade de Filosofia, Letras e Ciências Humanas da Universidade de São Paulo, para a obtenção do título de Mestre em Letras.

Área de concentração: Filologia e Língua Portuguesa

Orientadora: Prof. ${ }^{\text {a }}$ Dr. a Maria Inês Batista Campos 
Autorizo a reprodução e divulgação total ou parcial deste trabalho, por qualquer meio convencional ou eletrônico, para fins de estudo e pesquisa, desde que citada a fonte.

Catalogação na Publicação

Serviço de Biblioteca e Documentação

Faculdade de Filosofia, Letras e Ciências Humanas da Universidade de São Paulo

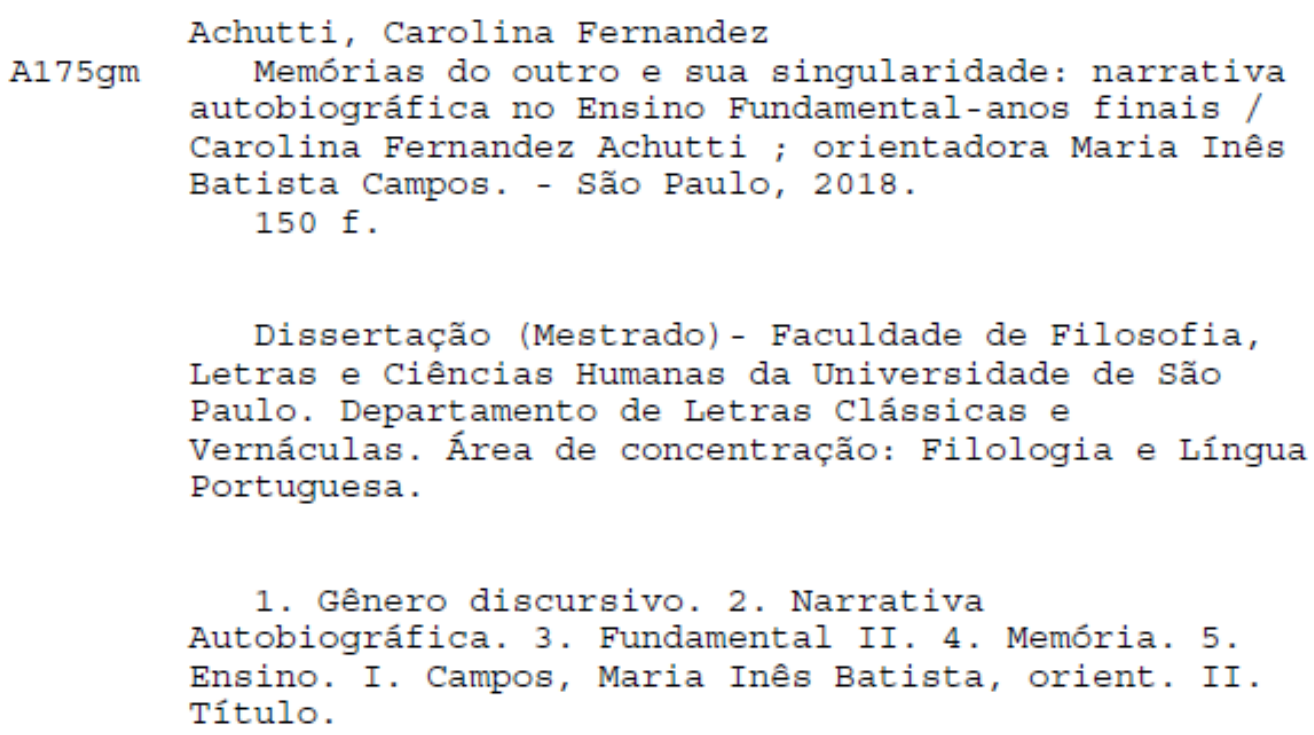


ACHUTTI, Carolina Fernandez. Memórias do outro e sua singularidade: narrativa autobiográfica no Ensino Fundamental - anos finais

Dissertação apresentada ao Programa de Pós-Graduação em Filologia e Língua Portuguesa, do Departamento de Letras Clássicas e Vernáculas da Faculdade de Filosofia, Letras e Ciências Humanas da Universidade de São Paulo, para a obtenção do título de Mestre em Letras.

Aprovada em:

\section{Banca Examinadora}

Prof. ${ }^{\text {a }}$ Dr. ${ }^{\text {a }} \quad$ Maria Inês Batista Campos Instituição: Universidade de São Paulo Julgamento:

Assinatura:

Instituição:

Julgamento:

Assinatura:

Instituição:

Assinatura:

Instituição:

Julgamento:

Assinatura: 


\section{AGRADECIMENTOS}

Aqui e agora escrevo essas palavras com o coração emocionado e na mente ecoa a máxima de Bakhtin, a qual diz que "não há álibi para a existência." Viver no mundo compromete e é uma empreitada perigosa. A caminhada foi dura, mas prazerosa. Exaustiva, mas gratificante. Ter companheiros fez tudo parecer mais fácil. O apoio da minha orientadora, Maria Inês, foi essencial, foi além do teórico; soube ter a delicadeza de dar o espaço para que eu pudesse viver e sentir acontecimentos difíceis durante os dois passados anos. Em muitas reuniões de orientação, foi a minha psicóloga e esteve com os ouvidos atentos para as minhas inseguranças, pronta para ser assertiva o suficiente para me levantar, injetando doses homeopáticas de adrenalina para que tudo acontecesse, além de ajudar com pesquisas que geram resultados que só ela é capaz de achar.

Aos meus pais, que são a minha base, retornei ao meu lar e encontrei conforto. Caminhamos juntos. Minha irmã gêmea, Camila Achutti, minha imagem e semelhança, esteve ali, serviu como um incentivo. Eu a vi perder todos os fins de semana durante a reta final de seu mestrado, isso me fazia seguir muito forte, pois, ao olhar a sua dedicação, obrigava-me a dar sempre mais. Estamos juntas pensando na educação, compartilhamos referenciais e ideais em áreas tão distintas.

Aos amigos e aos colegas do grupo de estudo, agradeço pela paciência de não desistirem de mim, que por vezes me ausentei por conta dos compromissos acadêmicos. Receber amor e carinho é essencial para que a caminhada siga mais serena. Obrigada do fundo da minha alma.

Agradeço ao Sistema Anglo de Ensino, ao Colégio Anglo21 e ao Descomplica por serem ambientes de trabalho tão engrandecedores.

À Universidade de São Paulo, especialmente ao Departamento de Letras Clássicas e Vernáculas da Faculdade de Filosofia, Letras e Ciências Humanas pelo ambiente desafiador.

Por fim, agradeço aos meus alunos, os participantes da pesquisa e os protagonistas da minha vida. Todos que um dia me chamaram de professora fazem parte do que sou. Não há nenhum título que me faça mais feliz. Sou professora com o coração e a alma. 
Não é no silêncio que os homens se fazem, mas na palavra, no trabalho, na açãoreflexão. 


\section{RESUMO}

ACHUTTI, Carolina Fernandez. Título: Memórias do outro e sua singularidade: narrativa autobiográfica no Ensino Fundamental - anos finais. 2018. 150p. Dissertação (Mestrado). Faculdade de Filosofia, Letras e Ciências Humanas, Universidade de São Paulo, São Paulo/SP. Versão corrigida.

A importância das atividades escolares com narrativas autobiográficas é levar os estudantes a um movimento de interiorização, alimentando a imaginação de como contar aos outro sua pequena biografia. Nas autobiografias escolares, a escrita permite aos alunos tornarem-se autores de suas próprias trajetórias, e traçar o processo sócio-histórico em que viveram e vivem. Nesta dissertação, a proposta de escrita autobiográfica com duas turmas do $7^{\circ}$ ano dos anos finais do ensino fundamental mostrou-se relevante devido a três aspectos: a) o envolvimento dos participantes de 12 anos com a criação de um texto pessoal; b) em cada relato da curta vida dos jovens há um processo da comunicação breve alimentando o texto; c) o acompanhamento da leitura do conjunto de textos permite ao leitor uma valorização de objetos, lugares e pessoa trazidos pelos alunos que contam rápidas biografias e constroem a singularidade dos percursos juvenis. Assim, o ensino de produção escrita pode ser potencializado pelo estudo dos gêneros discursivos que se voltam para o eu do aluno. O objetivo central desta dissertação é analisar a singularidade e a memória discursiva de jovens do $7^{\circ}$ ano. Por meio de textos produzidos durante uma sequência didática, busca-se identificar os procedimentos linguístico-discursivos utilizados na estruturação dos textos, verificando as categorias de tempo e espaço empregadas na reorganização da trajetória de vida, a fim de compreender as marcas valorativas que constituem a identidade dos alunos. Desta forma, duas perguntas norteiam este estudo: 1. De que maneira linguístico-discursiva os estudantes reconstroem o tempo e o espaço? 2. Quais elementos memorialísticos emergem das narrativas autobiográficas? Como pressupostos teóricos, o conceito de gênero discursivo, de Mikhail Bakhtin e o Círculo e a noção autobiográfica na perspectiva teórica de Philippe Lejeune e de Leonor Arfuch com a finalidade de aprofundar características do gênero autobiográfico. A partir da análise do corpus organizado com a produção e reelaboração de 42 redações, os resultados indicam a importância do ato de escrever sobre si, o que possibilita ao aluno ampliar seu repertório de visões de mundo, uma vez que se abre uma possibilidade com a subjetividade, ainda de maneira breve por se tratar de jovens autores. Ao se voltarem para as suas vidas, temas singulares que guardam dentro de si se tornam matérias fundamentais para a construção de narrativas sobre perdas e deslocamentos. Essa constante mudança de valores dos jovens do século XXI configura processos identitários.

Palavras-chave: Gêneros discursivos. Narrativa autobiográfica. Ensino. Memória. Fundamental II. 


\begin{abstract}
ACHUTTI, Carolina Fernandez. Title: Memories and singularity: autobiographical narrative in Elementary School. 150p. Dissertation (MA) - Faculdade de Filosofia, Letras e Ciências Humanas. University of São Paulo, São Paulo, 2018. Original version.
\end{abstract}

The importance of school activities with autobiographical narratives is to lead the students to a movement of interiorization, fueling the imagination of how to tell the others their small biography. In school autobiographies, writing allows students to become authors of their own trajectories, and to trace the socio-historical process in which they live and lived. In this dissertation, the proposal of autobiographical writing with two classes of the 7th grade of elementary school proved to be relevant due to three aspects: a) the involvement of the participants of 12 years with the creation of a personal text; b) in each account of the short life of the young there is a process of fleeting communication feeding the text; c) monitoring the reading of the set of texts allows the reader to appreciate the objects, places and person brought by the students that count quick biographies and build the uniqueness of the youth pathways. Thus, the teaching of written production can be enhanced by the study of the discursive genres that turn to the student's self. The main objective of this dissertation is to analyze the singularity and the discursive memory of young people of 7 th grade. Through texts produced during a didactic sequence, the aim is to identify the linguisticdiscursive procedures used in the structuring of texts, verifying the categories of time and space used in the reorganization of the life trajectory, to understand the value marks that constitute the identity of the students. Thus, two questions guide this study: 1. In what linguistic-discursive way do students reconstruct time and space? 2. What memorialistic elements emerge from autobiographical narratives? As theoretical assumptions, the concept of discursive genre, by Mikhail Bakhtin and the Circle and the autobiographical notion in the theoretical perspective of Philippe Lejeune and Leonor Arfuch with the purpose of deepening on characteristics of the autobiographical genre. From the analysis of the organized corpus with the production and reelaboration of 42 essays, the results indicate the importance of the writing act on itself, which allows the student to expand his / her repertoire of world visions, since a possibility opens with subjectivity, even superficially because they are young authors. When they return to their lives, unique themes that they keep inside themselves become fundamental subjects that construct narratives like losses and displacements. This constant change is central to the identities of young people in the 21 st century.

Keywords: Discursive genres. Autobiographical text. Education. Memory. Elementary School. 


\section{CAPÍTULO 1}

EM TORNO DO TEXTO AUTOBIOGRÁFICO

1.1 Autobiografia como gênero do discurso

1.2 O tempo e o espaço na relação eu-para-si

\section{CAPÍTULO 2}

O TEXTO AUTOBIOGRÁFICO NAS AULAS DE LÍNGUA PORTUGUESA 30

2.1 A autobiografia na esfera escolar $\quad 30$

2.2 A literatura e o eu $\quad 38$

2.3 A escrita e a reescrita $\quad 43$

\section{CAPÍTULO 3}

PROPOSTA TEÓRICO-METODOLÓGICA DE ATIVIDADE DE PRODUÇÃO DE TEXTO AUTOBIOGRÁFICO NO 7 ANO 47

3.1 espaço da escrita nas aulas de português em escola particular $\quad \mathbf{4 7}$

3.2 Atividades de escrita autobiográfica no $7^{\circ}$ ano: da leitura à produção $\mathbf{5 2}$

3.3 Etapas da produção escrita em aula $\quad \mathbf{5 7}$

3.4 Organização e desenvolvimento das atividades didáticas $\quad \mathbf{5 8}$

\section{CAPÍTULO 4}

NARRATIVAS AUTOBIOGRÁFICAS DE ALUNOS DE 7ㅇ ANO:

TEMPO DE MUDANÇA

4.1 Em torno do tempo 66

4.2 Em torno do espaço $\quad 71$

4.3 Explorando mudanças e suas memórias $\quad 73$

$\begin{array}{ll}\text { CONSIDERAÇÕES FINAIS } & 89\end{array}$

$\begin{array}{ll}\text { REFERÊNCIAS } & 92\end{array}$

$\begin{array}{ll}\text { ANEXO } & 97\end{array}$ 


\section{INTRODUÇÃ̃O}

\section{Considerações iniciais}

A busca deste trabalho é pelo reconhecimento dos alunos por meio de seu próprio discurso, reconhecer a sua individualidade, tratando-os como indivíduos singulares. Enxerga-se a esfera escolar como um ambiente social e mais, esse espaço como o principal ambiente de socialização do jovem e por isso, a importância em ceder lugar para a sua subjetividade. As narrativas autobiográficas como objeto de estudo valorizam e exploram as dimensões pessoais dos sujeitos, seus sentimentos e trajetórias de vida, e levam à percepção da complexidade das interpretações que os indivíduos pesquisados fazem de suas experiências e ações, sucessos e fracassos e dos problemas que enfrentam.

Este trabalho está inserido no projeto Argumentação, ensino, memória: por uma teoria dialógica da linguagem, liderado pela Professora Doutora Maria Inês Batista Campos. O programa reúne análises linguístico-discursivas de produções escritas, visando às atividades didáticas significativas para o ensino de língua materna em materiais didáticos do Ensino Fundamental II e Médio, sob as lentes filosóficas e epistemológicas dos estudos bakhtinianos.

A proposta é formalizada por meio de narrativas autobiográficas no $7^{\circ}$ ano, e tem o material do Sistema de Ensino Anglo como norte, pois foi a partir do trabalho com tais materiais que se notou a necessidade de produção de narrativas com foco na experiência de expressões subjetivas. Para tratarmos sobre este tema, recorremos ao denso ensaio da fase filosófica de Mikhail Bakhtin, intitulado $O$ autor e a personagem na atividade estética, em que ele diferencia o autor-pessoa e o autorcriador (Bakhtin, 2011) 
o autor reflete a posição volitivo-emocional da personagem e não sua própria posição em face da personagem; (...) o autor cria, mas vê em sua criação apenas no objeto que ele enforma, isto é, vê dessa criação apenas 0 produto em formação e não 0 processo interno psicologicamente determinado (BAKHTIN, 2011, p. 5).

O primeiro elemento a ser pensado é a questão do acabamento do acontecimento que ocorre de forma externa ao texto e deve ser pensado a partir da relação entre vida e arte. Para Bakhtin, a vida não tem acabamento enquanto vida, apenas na arte é possível darmos um desfecho concreto para um acontecimento. Desta forma, demonstra que é a partir do excedente de visão que o autor realiza a conclusão da obra, o autor deve colocar-se à margem de si, vivenciar a si mesmo não no plano em que efetivamente vivenciamos nossa vida; só sob essa condição ele pode completar a si mesmo, até atingir o todo, com valores que a partir da própria vida são transgredientes a ela e the dão acabamento; "ele deve tornar-se outro em relação a si mesmo, olhar para si mesmo com os olhos do outro" (BAKHTIN, p. 13).

O segundo elemento levantado por Bakhtin é a diretriz volitivo-emocional concreta, o sentimento e o desejo de mundo "é abrangido de todos os lados, como em um círculo, pela consciência concludente do autor a respeito dele e do seu mundo" (Idem, p. 11).

O último elemento, porém, não menos importante e que possibilita a reflexão acerca da arquitetônica é o centro axiológico que Bakhtin define como "o todo da personagem e do acontecimento a ela referente, ao qual devem estar subordinados todos os valores éticos e cognitivos" (Idem, p.11). A partir das narrativas produzidas pelos alunos é possível identificar valores éticos e identitários dos educandos.

Autor e personagem são um só na autobiografia, são concomitantes. E a escolha do gênero decorre justamente dessa percepção de que é um gênero em que o "eu" e outro são o mesmo. O "eu" precisa recuar até que tenha uma autopercepção de si, deve colocar-se à margem de si. Em outros termos, deve se tornar um outro de si mesmo: o autor se avalia a partir do olhar alheio para retornar a si mesmo com nova percepção acerca de seu todo estético e axiológico.

A experiência autobiográfica permite ao jovem uma aproximação consigo mesmo, e por isso a escolha desse momento de transição entre a infância e a adolescência, ou seja, o $7^{\circ}$ ano, pois segundo a Lei Federal 8.069/90 do Estatuto da Criança e do Adolescente, Art. 20: "Considera-se criança, para os efeitos desta Lei, a pessoa até doze anos de idade incompletos, e adolescente aquela entre doze e 
dezoito anos de idade" para entendemos quem são esses jovens em uma fase cheia de transformações.

A principal motivação para a realização dessa dissertação é compreender a escrita produzida por estudantes do $7^{\circ}$ ano. Busca-se a escuta (ou no caso, a leitura) do que eles têm a escrever. Durante o processo da pesquisa, o desejo de conhecêlos melhor manteve-se vivo. Saber mais sobre suas vidas e sobre como eles escrevem. O texto autobiográfico é um aprendizado significativo, no qual jovens de 12 anos experimentam olhar para si mesmos, o que traz, em última instância, a possibilidade de que eles se percebam como sujeitos ativos em um período de grande mudança.

A pesquisa nasceu de uma professora que buscava meios de se comunicar com os jovens de uma escola pública paulista. De maneira intuitiva, resolveu se apresentar por meio de uma carta autobiográfica, que na verdade não passava de linhas com gostos e acontecimentos enumerados, mas isso tocou os jovens carentes de atenção. A tal carta obteve mais de cinquenta respostas. Desse evento nasceu a vontade de tornar aquela ideia um projeto de pesquisa.

Compreender o gênero autobiográfico foi a primeira etapa de averiguação. Após o levantamento de estudos brasileiros que envolviam o gênero autobiográfico, a fim de atestar a importância e a relevância desse tipo de estudo com o gênero em questão, iniciou-se o trabalho com a pesquisa na Associação Brasileira de Pesquisa (Auto)Biográfica, um portal que reúne trabalhos e organiza eventos acerca do tema.

Notamos, então, que um amplo número de trabalhos usa as narrativas autobiografias como ferramenta de pesquisa da trajetória do professor e de seu fazer docente ou então, constroem análises de obras literárias autobiográficas. Contudo, crianças e jovens não aparecem como produtores deste gênero, o que de alguma maneira não tem uma justificativa, afinal todos concordam que por meio dessas histórias de vida, pode-se descobrir muito sobre os indivíduos e sobre uma comunidade.

Segundo Antonio Bolívar, professor da Universidade de Granada na Espanha, Doutor em Filosofia e Ciências da Educação, a pesquisa com o uso de narrativas pressupõe uma mudança no que se entende como conhecimento em Ciências Sociais, pois se deve deixar de lado a abordagem que valoriza a objetividade e reforça o distanciamento entre o pesquisador e o sujeito, dando lugar para as narrativas 
pessoais que destacam a subjetividade, ou seja, relevam a singularidade, e essa é exatamente a busca almejada (BOLIVAR, 2002).

A biografia e a autobiografia se instituem cada vez mais como gêneros narrativos capazes de recuperar a vida cotidiana, lidando com questões que a escola muitas vezes deixa de lado de maneira responsável, por isso é um ambiente tão fecundo. Ao tratar do valor biográfico, Bakhtin (2011), afirma que a escrita do "eu" sobre o "eu" é, antes de tudo, um ato de consciência. O exercício autobiográfico usa o recurso da lembrança e da memória, fazendo com que o autor recapitule o espaço e o tempo, e que ele mesmo organize suas questões mais profundas.

Em pequena escala, buscou-se estudiosos da psiquiatria para reforço do valor da atividade com a autobiografia. Pennebaker (1989) afirma que a verbalização de uma vivência autobiográfica, principalmente de momentos traumáticos pode ter efeito benéfico em longo prazo, bem como a retenção dessas informações pode elevar níveis de estresse, e Vandenberg (2004) relata que, ao se falar sobre lembranças autobiográficas emocionalmente negativas, há uma reorganização dos conteúdos relatados, visto que uma estrutura de conectividade é ativada quando uma pessoa revive as emoções, modificando assim o padrão de ativação neural.

\section{Problematização}

A escrita é uma das habilidades exigidas pelo currículo escolar, por isso é interessante o mapeamento de como se dá a sua aprendizagem, para que, de antemão, possa-se construir as bases desta dissertação. Segundo Geraldi (1993), a aprendizagem da escrita é feita por meio da prática, uma vez que ela não é um produto acabado, mas um processo por meio do qual se resolvem os problemas, que vão desde a tomada de decisões acerca daquilo que se quer dizer, à forma como se vai fazer e até com qual finalidade se diz algo. Por essa razão, a escrita requer uma seleção cuidadosa para uma combinação bem-sucedida das expressões linguísticas, para que assim estejam organizadas em unidade compatível com o que se quer expressar.

Não se trata apenas de manejo entre aspectos gramaticais e ortográficos, há muito além disso, contudo, muitos docentes de Língua Portuguesa (LP) desconsideram esses elementos, deixando de lado as funções sociais da escrita, por 
exemplo, e, acredita-se que é, justamente, a falta de materialidade da produção textual em sala de aula que acaba por gerar tanta dificuldade. É o distanciamento entre texto e aluno que torna a escrita na esfera escolar uma atividade dificultosa e problemática. Mesmo depois do advento dos PCNs (Parâmetros Curriculares Nacionais, 1998), ainda hoje, após mais de 20 anos, é comum ver alunos escrevendo textos sem uma função comunicativa/social ou, ainda, livros didáticos ou materiais apostilados fazendo uma abordagem rasa e descontextualizada de textos e de propostas de produção textual. O aluno acaba sem destino, fica sem saber o porquê: Por que ele escreve? Para quem ele escreve? Para que ele escreve? Sobre o que ele escreve? (GERALDI, 1993).

Para que se possa discutir a questão proposta nesta dissertação, tem-se que ter clareza do que é o texto, pois ele é o elemento central no ensino da língua materna, mais especificamente, na prática e no desenvolvimento da habilidade da escrita. Ao considerar o texto como forma de interação, na qual os sujeitos são vistos como construtores sociais, pois interagem trocando experiências e conhecimentos, tem-se uma concepção do que é a escrita, muito diferente da que é observada em muitas escolas, livros didáticos e sistemas de ensino brasileiros. O discurso na escola deve ser visto como o principal lugar de interação, porque é a partir dele que professor e aluno trocam informações. O leitor (professor) e o autor (aluno) do texto têm um papel ativo, visto que dialogam; há uma atitude responsiva ativa.

Tem-se o texto como objeto de uso e não como objeto de ensino. Por vezes, o texto é apenas um "pretexto" para um ensino da gramática. Há um desligamento completo das circunstâncias de produção e de leitura de textos em muitos momentos, o que torna o trabalho com o texto apenas uma tarefa de extração de informações (ROJO; CORDEIRO, 2004, p.9-10).

Para dar conta das diferentes abordagens possíveis para o texto, Geraldi (1993, p. 135) apresenta duas perspectivas metodológicas para o trabalho com a escrita: uma que determina o texto "para a escola", pois o aluno produz uma redação/texto, para o professor ler e atribuir nota, sem demonstrar o seu ponto de vista, e o texto "na escola", responsável pela produção de texto, na qual o aluno está presente como sujeito, atribuindo-Ihe opinião e o professor aparece não apenas como um avaliador mas como um leitor ativo. 
É primordial, para a produção de um texto, como diz Geraldi (1993, p. 137) que "se tenha o que dizer", isto é, o emissor deve possuir um conteúdo para ser desenvolvido; "se tenha uma razão para dizer o que se tem a dizer", ou seja, deve haver uma intenção para se escrever; "se tenha para quem dizer", o texto deve possuir um interlocutor que irá lê-lo. O aluno deve ser visto como um sujeito "que enuncia o que diz e tem consciência absoluta de seu dizer, pois sabe o que diz. Trata-se de um sujeito pronto que, apropriando-se da língua, atualiza-a no seu dizer..." (Idem, 1993, p.19). O domínio da língua consiste, em especial, na aquisição de determinado grau de domínio de escrita e leitura, isto é, que o aluno consiga escrever sem traumas, diferentes tipos de textos e ler produtivamente também textos variados, segundo Possenti (1997, p.40).

É o que hoje determina o nível de letramento que, de acordo com Soares (2002), significa a habilidade de o sujeito saber fazer uso competente dos diferentes tipos de materiais escritos, compreendê-los e extrair informações para poder viver em uma sociedade que valoriza a informação. É a partir dessas bases que a Atividade 1 foi elaborada será apresentada no Capítulo 3. A competência da leitura e da escrita se constrói por meio da prática significativa, contextualizada e efetiva de textos variados. E é essa técnica que se busca com o ensino da autobiografia, principalmente para $\circ 7^{\circ}$ ano, momento no qual julga-se que os alunos estão preparados para lidar com a língua com mais maturidade, mas ainda estão no início desse processo.

A escrita não é um produto escolar, mais sim, um objeto cultural, resultado do esforço coletivo da humanidade, e sendo um objeto cultural, a escrita cumpre diversas funções culturais. Ou seja, a produção da escrita começa antes da escolarização, e na atividade com a autobiografia há potencialmente a confluência do mundo cultural e do histórico do jovem.

A aprendizagem é um fenômeno extremamente complexo, a qual envolve aspectos cognitivos, emocionais, orgânicos, psicossociais e culturais. Ela é resultante do desenvolvimento de aptidões de conhecimentos, bem como da transferência destes para uma nova situação. Conseguir unir tais elementos é um desafio e o que será tratado aqui é justamente o potencial do trabalho com a autobiografia com a ambição de atingir pais, professores e pesquisadores que estão preocupados com a formação dos jovens na leitura e na escrita, e ainda, a possibilidade de conhecer mais sobre quem são esses jovens em idade escolar, que já passaram por todo o Ensino 
Fundamental I, e hoje, após um ano no Fundamental II, já percebem os seus lugares com mais maturidade e clareza, tendo maior capacidade de abstração e tendo noção de categorias básicas de tempo, espaço e pessoa.

Faz-se necessário, ainda, o apontamento de uma fonte de inspiração teórica e científica, e mais, uma inspiração para a docência na educação fundamental, Michele Petit; sua obra Leituras: do espaço íntimo ao espaço público deu rumo ao presente trabalho. No capítulo 2 da obra citada, Construir leitores, encontram-se respostas, pois a grande busca aqui é construir escritores, construir pessoas competentes na língua materna, alunos que não tenham medo da folha em branco, ou até, de um livro recheado de palavras. Petit (2013, p.31) coloca que a leitura pode "ajudar as pessoas a construírem, a descobrirem, a se tornarem um pouco mais autoras de suas vidas, sujeitos de seus destinos", exatamente o potencial que se tem com a produção textual, principalmente na produção de gêneros que aproximem a história de vida, as experiências dos alunos e o ensino escolar.

\section{Perguntas de pesquisa e objetivos}

Tal investigação se justifica por abordar o texto autobiográfico a partir de uma perspectiva linguístico-discursiva, analisando o trabalho com o gênero em questão com jovens em fase de transição para a adolescência, como uma forma de ressignificação do ensino de produção escrita. Os objetivos são: (a) descrever e analisar os textos autobiográficos em relação às categorias linguístico-discursiva de tempo e espaço; (b) discutir a singularidade das narrativas autobiográficas e seus traços identitários, a fim de realocar a discussão da produção escrita no $7^{\circ}$ ano como uma relação de ressignificação da escrita para si e para o outro.

Os jovens em questão fazem parte da classe dominante e não encontram tantas dificuldades de aprendizagem, uma vez que já apresentam certo domínio da escrita por terem acompanhamento escolar de qualidade. O objetivo é trabalhar com a experiência de leitura e a produção de texto final a partir dos documentos oficiais, como nos PCN+ (Parâmetros Curriculares Nacionais, 2002) em que se orienta a leitura para a produção de sentido, pois aprender a ler de modo amplo e em vários níveis é aprender a se comunicar (p.107). 


\section{Organização dos capítulos}

Esta dissertação analisa narrativas autobiográficas de estudantes do $7^{\circ}$ ano, a partir da leitura participativa de excertos literários, explorando, principalmente, a memória da experiência vivida. Para isso, busca-se identificar e relacionar as marcas linguísticas de pessoa, tempo e espaço para a reconstrução dos textos autobiográficos. As imagens que ativam a memória dos estudantes de $7^{\circ}$ ano demonstram características valorativas do grupo.

Há quatro capítulos. O Capítulo 1 reúne o levantamento teórico do que é o texto autobiográfico para a teoria Bakhtiniana a partir do conceito de gêneros do discurso. Em seguida, as categorias de tempo e espaço e, por fim, discute a pessoa que fala.

Na sequência, ao restringir a esfera de produção, trata-se especificamente do contexto escolar, realizando a relação entre leitura e produção textual e, aborda-se escrita e reescrita no contexto da aula de Língua Portuguesa.

No Capítulo 3, tem-se a metodologia, descrevendo a abordagem contida no material didático e o processo de estruturação da proposta didática. Por fim, no Capítulo 4, a análise se organizará em torno das categorias de tempo e espaço e das marcas e valores identitários, para que se construa a análise do material linguístico e a questão memorialística nas narrativas autobiográficas que compõe o corpus. 


\title{
CAPÍTULO 1
}

\section{EM TORNO DO TEXTO AUTOBIOGRÁFICO}

\begin{abstract}
O que ainda devo dizer ao senhor? Parece-me que tudo foi enfatizado da maneira apropriada; por fim, gostaria apenas de aconselhá-lo a passar com serenidade e seriedade pelo período de seu desenvolvimento. Não há meio pior de atrapalhar esse desenvolvimento do que olhar para fora e esperar que venha de fora uma resposta para questões que apenas seu sentimento íntimo talvez possa responder, na hora mais tranqüila.
\end{abstract}

Rilke, 2009

Neste capítulo, a abordagem se dá por meio texto autobiográfico a partir de conceitos teóricos, principalmente do ponto de vista literário, baseando-se no conceito de gênero discursivo de Mikhail Bakhtin, de espaço biográfico de Eleanor Arfuch e de pacto autobiográfico de Philippe Lejeune. Inicialmente, discorrendo sobre a questão de gênero de modo amplo, posteriormente, o enfoque para duas categorias centrais, a de tempo e a de espaço, e, ao final, a questão autoral, que tanto terá valor para o momento de análise.

\section{Autobiografia como gênero do discurso}

Trata-se aqui do texto autobiográfico, apresentando uma revisão bibliográfica e possíveis aproximações entre estudiosos que trataram do gênero em questão. Mikhail Bakhtin, filósofo e pensador russo e estudioso da questão autobiográfica; Além deste, buscou-se dois estudiosos do assunto que, apesar de diferentes, são complementares para o desenvolvimento deste trabalho acadêmico e para uma atividade acessível aos alunos de $7^{\circ}$ anos: Lejeune parece-nos didático, trazendo conceituações definidas; já 
Arfuch, alinha-se aos estudos teóricos sobre o gênero, com grande proximidade junto aos estudos bakhtinianos, tratando também sobre questões da identidade contemporânea. Ambos são referências unânimes sobre o gênero autobiográfico e por isso foram contemplados neste estudo.

Investigar a autobiografia na dimensão narrativa e discursiva, olhando a partir de diferentes abordagens e pensadores, possibilita o acesso aos modos de sentir e viver, o estético e o ético de quem escreve em primeira pessoa de diferentes formas, o que será discutido mais adiante.

Bakhtin não estabelece diferença na abordagem da biografia e da autobiografia, pontuando que "diferença existe, evidentemente, e pode ser grande, mas não se situa no plano da diretriz axiológica básica da consciência" (2011:138). A escrita sobre o "eu" ocupa lugares mentais e faz uso do recurso da lembrança e da memória, ou seja, é como se o autor recapitulasse o espaço e o tempo de uma história, no caso da autobiografia, de sua própria história.

O texto autobiográfico é a "descrição de uma vida" (idem:139), a forma transgrediente imediata em que há uma objetificação estética da trajetória de vida do autor. É a materialidade da coincidência entre o autor e o herói. É a concomitância entre o pessoal "na vida" da pessoa de quem se fala com a pessoa que fala.

A questão central do texto autobiográfico é o valor autobiográfico, o que não só organiza a narração sobre a vida do outro, mas também o vivenciar da própria vida, é a visão e a enunciação da própria vida.

A força organizadora do texto autobiográfico é a consciência, juntamente com o contexto axiológico. Há uma divisão básica dos tipos de consciência autobiográfica:

1. Aventuresco-heroico (p.143): vontade de ser herói, de ter importância no mundo dos outros; a vontade de ser amado; a vontade de superar a fabulação da vida, a diversidade da vida anterior e exterior;

2. Social de costumes (p.147): aqui o centro axiológico são os valores culturais históricos que organizam a forma do herói.

Reconhece-se o tipo social-de-costumes, pois há um centro de valores culturais e históricos, restrito ao âmbito familiar e escolar. Predominam elementos descritos 
que, muitas vezes, são conhecidos através das palavras alheias de pessoas íntimas. Depende-se disso para reconstituir a vida com unidade biográfica axiológica.

Os alunos se tornam heróis da própria vida e só se tornam autores com a "familiarização axiológica estreita e orgânica" (p. 142), pois alcançam a autoobjetivação. É possível considerar a autobiografia não como um mero discurso direto do escritor sobre si mesmo, pronunciado do interior do evento da sua vida, mas como um relato sobre a própria vida. $\mathrm{O}$ escritor precisa se posicionar axiologicamente frente à própria vida, submetendo-a a uma valoração que transcenda os limites do somente vivido. A autobiografia está intimamente amarrada à historicidade do indivíduo, ela se situa na fronteira entre a expressão do "eu" e a do personagem.

Dessa forma, o autor sempre verá a si mesmo como um outro possível, um objeto passível de criação estética. Trata-se de um movimento de desdobramento do "eu" em outro. Fora o nome, a figura do autor nunca coincidirá com a da personagem ou a do narrador. É esse desdobramento e essa coincidência entre universos de valores que tornam a autobiografia um gênero tão único, que fez com que estudiosos se dedicassem ao seu estudo, como os dois escolhidos, Bakhtin e Lejeune.

É essencial destacar que, para Bakhtin, aquilo que o sujeito narra sobre si mesmo não deve ser entendido como uma expressão de um discurso solitário e individual, já que diversas vozes são incorporadas, por isso o autor chama a atenção para a polifonia na construção de memórias.

\begin{abstract}
Tomo conhecimento de uma parte considerável da minha biografia através das palavras alheias das pessoas íntimas e em sua tonalidade emocional: meu nascimento, minha origem, os acontecimentos da vida familiar e nacional na minha tenra infância (tudo o que não podia ser compreendido ou simplesmente percebido por uma criança). Todos esses momentos me são necessários para a reconstituição de um quadro minimamente inteligível e coerente da minha vida e de seu mundo, e eu, narrador de minha vida pela boca das outras personagens, tomo conhecimento de todos aqueles conhecimentos. Sem essas narrações das outros na minha vida não ficaria inteira (BAKHTIN, 2011:141-142).
\end{abstract}

Em uma análise mais profunda pode-se perceber que o "eu" se esconde no outro e nos outros. O movimento narrativo da autobiografia, um olhar do "eu" sobre si mesmo, transporta a noção de autoconsciência para o espaço da representação e abstração; aqui uma análise ainda mais profunda, mais do que o "eu" e o outro coincidirem, na verdade, Bakhtin diz que o ligar desse "si mesmo" não corresponde 
nem ao "eu" nem ao outro, mas à uma imagem, a imagem que o sujeito faz, ou melhor, cria de si - uma identificação, criada em virtude de certo olhar lançado sobre um outro.

Reconhecido como o grande estudioso da autobiografia, Phillipe Lejeune dedicou-se a estudá-la, definindo-a como uma "narrativa retrospectiva em prosa que uma pessoa real faz de sua própria existência, quando focaliza sua história individual, em particular a história de sua personalidade" (LEJEUNE, 2008:14). Segundo o teórico francês, para existir qualquer gênero de literatura íntima (autobiografia, diário, memórias) é necessário haver uma relação de identidade onomástica entre autor (cujo nome está estampado na capa), narrador e a pessoa de quem se fala.

Lejeune reconhece a impossibilidade do estabelecimento de diferenças entre autobiografias e romances autobiográficos a partir de uma análise meramente textual, já que os procedimentos narrativos de uma autobiografia são comumente imitados em textos ficcionais, é precisamente essa identidade do nome entre autor-narradorpersonagem que vai firmar com o leitor o "pacto autobiográfico", "a afirmação, no texto, dessa identidade, remetendo, em última instância, ao nome do autor, escrito na capa do livro" (LEJEUNE, p. 26).

Assim, a autobiografia é "uma narrativa introspectiva em prosa que uma pessoa real faz da própria existência, quando essa pessoa acentua sua vida individual, em particular, a história de sua personalidade" (LEJEUNE, 1975:14).

Segundo ele, uma autobiografia deve apresentar os seguintes elementos "relativamente estáveis":

a) a forma da linguagem deve ser narrativa, em prosa;

b) o assunto tratado diz respeito à vida individual, à história de uma personalidade;

c) deve haver identidade do autor, devendo ser uma pessoa real (e não um personagem ficcional);

d) é preciso que haja coincidência entre a identidade do narrador e um personagem principal;

e) a narrativa deve possuir uma perspectiva retrospectiva, deve falar do passado.

A presença do nome, que é o que confere o status de verdade, é o que conecta personagem e autor. Lejeune (1975) propõe para isso a noção largamente explorada de pacto autobiográfico. Trata-se de uma espécie de contrato entre autor/leitor cujo fiador seria o nome próprio do autor (estampado na capa, por exemplo); e, no caso 
das redações escolares no alto da página, marca indiscutível que associa a obra à pessoa real do autor, a quem se atribui a responsabilidade pela enunciação.

São múltiplas as definições do pacto. Lejeune, como já mencionado, foi apurando o conceito. Por exemplo, a autobiografia foi considerada inicialmente como um discurso literário, sempre em forma de prosa e posteriormente passa a ser tratada em suas variadas formas de manifestação - no campo dos estudos sociológicos, no cinema, nas artes plásticas, a escrita cotidiana de diários e correspondências, na prática de blogs na Internet, etc.

Ao mesmo tempo em que essa ampliação do objeto de estudos demanda outro tipo de abordagem, ela também vai se tornar cada vez mais autobiográfica - como observa Noronha na apresentação do livro O pacto autobiográfico: de Rousseau à Internet, "em um estilo cada vez mais metafórico e subjetivo, assumindo a própria forma de seu objeto" (NORONHA, 2008, p. 10). Assim, a escrita de Lejeune, conforme ele se aprofundou nos estudos desse gênero, torna-se mais subjetiva, pois há o emprego da primeira pessoa no singular; a parcialidade e a relativização das posturas tomadas; a possibilidade de colocações contraditórias; a retomada de textos escritos anteriormente; a relação com o próprio processo de escrita e o apelo ao leitor.

Ao buscar, nos textos de análise, pactos que permitissem uma leitura autobiográfica, Lejeune faz também pactos com seu leitor. Segundo, Pace (2013), de um texto a outro do autor, tem-se o abandono de uma teorização mais formalista e normativa do pacto e de seu funcionamento em textos literários, presente nos primeiros escritos, e uma aproximação de um relato de pesquisa, em que se relativizariam as posturas tomadas anteriormente. $\mathrm{O}$ que abre margem e incentiva o trabalho com a autobiografia nas mais diversas esferas.

\footnotetext{
A autobiografia, em textos mais recente, é colocada como um relato da história da personalidade de seu autor. Nesse sentido, ele se constrói num paradoxo: o autobiógrafo deve executar esse projeto de uma sinceridade impossível, servindo-se de todos os instrumentos habituais da ficção. Ele deve crer que há uma diferença fundamental entre a autobiografia e a ficção, ainda que, na verdade, para dizer a verdade sobre si mesmo, ele empregue todos os procedimentos de seu tempo. (LEJEUNE, 1975:17.)
}

Tem-se aqui, frente a frente, as duas referências, em que Lejeune fala em um projeto de sinceridade impossível e Bakhtin propõe que a consciência se desdobre, tornando-se autorreflexiva e autocrítica: 
O autor de biografia é aquele outro possível, pelo qual somos mais facilmente possuídos na vida, que está conosco quando nos olhamos no espelho, quando sonhamos com a fama, fazemos planos externos para a vida; é o outro possível, que se infiltrou em nossa consciência e frequentemente dirige nossos atos, apreciações e visão de nós mesmos ao lado do nosso eu-para-si; é o outro na consciência (...) (BAKHTIN, 2011:140).

Para Bakhtin, há possibilidade, pois não se trata apenas do "eu", mas do outro, são dois lugares que na autobiografia se aproximam, o "eu" e o outro. Assim, a sinceridade, que Lejeune traz como impossível, Bakhtin fala em o "eu" e o outro, são visões semelhantes, e são análises que diferem em relação a nomenclaturas, mas conseguem descrever esse gênero, tão fascinante, com clareza. E a partir daqui, tratase do tempo e do espaço, pois são os principais elementos organizadores da narrativa autobiográfica.

O empreendimento de Arfuch (2010) trata sobre os desdobramentos de um trio de questões envolvidas nessa esfera de pensamento: a subjetividade, o modo de narrar e a razão dialógica a partir do estudo de autobiografia. De maneira geral, isso é impactante para as Ciências Sociais, e essencial para a discussão das memórias de jovens estudantes.

O espaço biográfico só pode ser diagramado dentro da categoria da narrativa, já que a possibilidade de contar uma vida ou a própria vida, ou seja, a possibilidade de reconstrução mimética do vivido, acontece ao se organizarem os fatos, sentimentos, afetos, numa ordem temporal que é da narrativa obedecendo às regras e limites materiais dela própria. Por si só, esta restrição impede os mitos da autenticidade, ferindo mesmo a concepção de singularidade de uma vida.

A singularidade de cada um está na ordem do indizível. Não há possibilidade de coincidência do vivido com o relato, desde sempre a matéria da experiência está perdida, não se tem mais acesso a ela, uma possibilidade é organizá-la num fluxo narrativo. Também, segundo a autora, em pleno século $X X I$, o espaço biográfico ultrapassa em muito o gênero narrativo canônico, o qual será trabalhado aqui, mas existem muitas outras chances de ter acesso à palavra do "eu" sobre o "eu". Estenderse a novas modalidades de registro, como as entrevistas, os reality shows, os blogs, o que torna a possibilidade de leitura de "uma vida" mais abrangente e fluída, procedendo ao que a crítica argentina aponta como abertura às ressignificações do sujeito, processos de subjetivação plurais e dinâmicos. Ela ainda destaca, que o ressurgimento do interesse pelo biográfico guardaria ainda uma necessidade de 
entendimento de si por estratégias especulares, no caso do leitor, do espectador ou interlocutor.

Arfuch também registra a importância dos conceitos bakhtinianos como contribuição ao o seu trabalho. Ela menciona que se deve considerar o trabalho do filósofo russo como uma "translingüística", já que não se pode entender a língua isoladamente, concordando que qualquer análise linguística deve incluir fatores extralinguísticos, como contexto de fala, a relação do falante com o ouvinte, o momento histórico, etc.

Nesse sentido, Arfuch retoma de Bakhtin a noção das vozes narrativas dentro do relato biográfico. Despede-se, sob essa ótica, o "eu" unívoco e acata-se, em favor de uma razão dialógica, o descobrimento do princípio bakthiniano que punha em questão a unidade da voz narrativa: "Como estabelecer o quem do espaço biográfico? Como aproximar-se desse entrecruzamento das vozes, desses 'eu' que imediatamente se desdobram, não só em um 'tu' senão também em 'outros'?" (ARFUCH, 2002, p. 95). O "eu" do espaço biográfico encontra-se, desta maneira, sujeito a ressignificações constantes por "instâncias do auto-reconhecimento".

O "eu" autobiográfico, segundo Arfuch, é construído na oscilação entre a memória (conceito delicado, já que a memória, por vezes, como no caso da reconstituição da infância, é a memória dos outros e não a própria do indivíduo) e a mimeses, constituindo um jogo entre os aportes contextuais de família, sociedade, cultura, e a reconstituição, recriação ficcional.

Uma das metáforas utilizadas pela autora desenha o espaço biográfico como uma cebola que, de camada em camada, deixa o indivíduo sempre com as mãos vazias ao tentar atingir o núcleo de uma intimidade que escapa aos olhos do mais atento narrador, seja o autobiográfico, o do admirador, do biógrafo ou o do insistente ou do impertinente entrevistador.

Sem deixar de reconhecer a especificidade desse gênero fortemente ancorado na troca intersubjetiva e no compartilhamento de um solo comum de referências, trata-se de uma reflexão que, ao contrário de fortalecer as inclinações narcísicas e individualistas do "eu" inflado de nosso tempo, obriga o leitor a repensar o quadro da subjetividade numa rede de respostas e responsabilidades, como aponta uma das notas do terceiro capítulo sobre $A$ vida como narração, em que Arfuch fala sobre a responsividade, esta palavra própria do léxico de Bakhtin, para quem o enunciado se 
adianta às expectativas e objeções do outro, de modo a responder por antecipação a esse outro. Porém, este responder não é só "dar resposta" no sentido de contestar, preencher um turno vazio, mas também de assumir esse encargo, responder pelo outro: assim, responsividade e responsabilidade (não por acaso têm a mesma raiz) estarão ambas compreendidas. O dialogismo então é também uma ética. (ARFUCH, 2002, p. 96).

Após o panorama das três grandes referências teóricas, inicia-se o processo de delineamento da pesquisa, pensando em questões mais específicas do empreendimento, tratando do tempo e do espaço no próximo item, e a questão autoral ao final.

\subsection{O tempo e o espaço na relação eu-para-si}

A autobiografia pode ser tomada como um acontecimento privilegiado, em que se encontram a vida íntima do indivíduo e sua inscrição numa história social e cultural e tem como ponto de partida a retrospecção. Uma autobiografia é um construto textual sobre vivências experienciadas até o momento de sua narração, fala do ontem. Envolve estratégias autobiográficas desenvolvidas por um narrador, a partir das interrelações entre a memória e a autocompreensão.

As experiências, ao serem contadas, transpõem a vivência real para que se construa o registro da narrativa, para que sejam transformadas em textos. Passam a ser reguladas pelas regras de gênero e convenções que regem esse domínio. Dessa forma, o autor não coincide completamente com o personagem que protagoniza a ação, a começar por não compartilhar com este as condições de espaço e tempo. Assim, destaca-se a disjunção entre o sujeito que narra (narrador) e o foco narrativo, mesmo que na autobiografia se trate de um foco em primeira pessoa, como será visto no próximo item.

A partir da teoria bakhtiniana, para falar de tempo e espaço, Fiorin (2006), esclarece o conceito de cronotopo. A etimologia da palavra cronos é tempo e de topos, espaço, ambos da língua grega. O conceito foi elaborado por Bakhtin para estudar como as categorias de tempo e espaço estão representadas nos textos. Ainda de acordo com esse autor, os cronotopos são uma categoria conteudístico-formal e brotam de uma "cosmovisão", determinando a imagem do homem na literatura, pois 
constituem uma ligação entre o mundo real e o mundo representado, lugares que estão em interação mútua (FIORIN, 2006, p. 133).

O cronotopo de um texto é indissociável da concepção de homem e de mundo que nele está inscrito, pois no cronotopo artístico-literário ocorre a fusão dos indícios espaciais e temporais num todo compreensivo e concreto.

O tempo biográfico é "plenamente real, [já que] todos os seus momentos estão vinculados ao conjunto do processo vital"; o romance biográfico "opera com longos períodos", e, "no fundo desse tempo fundamental do romance biográfico constrói-se a representação de acontecimentos particulares e aventuras em plano grande" (BAKHTIN, 2011, p. 214).

Aqui o tempo se torna visível e o espaço penetra no movimento do tempo, do enredo e da história. Os índices do tempo transparecem no espaço, e o espaço se reveste de sentido e é medido com o tempo. A autobiografia é o lugar em que tempo e espaço se encontram.

Bakhtin introduz esse conceito em sua obra para garantir a ligação intrínseca das relações temporais e espaciais que são artisticamente expressas na literatura. Para nós o que é decisivo é o fato de que expressa a inseparabilidade do espaço e do tempo na narrativa.

Entende-se o conceito de cronotopo e sua complexidade enquanto categoria formalmente constitutiva da análise da literatura, por isso opta-se por manter espaço e tempo, uma nomenclatura mais simplificada, já que lidamos com as autobiografias curtas na esfera escolar para o $7^{\circ}$ ano, assim, lidar com espaço e tempo parece mais acessivel, ainda que se conheça a complexidade que está por trás desse conceito.

Na próxima etapa, será trabalhada pessoa do discurso, a questão autoral que envolve a empreitada autobiográfica. 


\subsection{A pessoa que fala}

No ensaio $O$ autor e a personagem, Bakhtin defende que "o artista nada tem a dizer sobre o processo de sua criação, todo situado no produto criado, restando a ele apenas nos indicar a sua obra; e é de fato, só aí que iremos procurá-lo" (BAKHTIN, 2011, p. 5). Essa afirmação pode ser estendida para outros gêneros discursivos que não somente os literários, pois ela aponta para as marcas pessoais, ou seja, estilísticas, que aquele que escreve costuma deixar em seu texto.

Há confusão entre autor-pessoa e autor-criador, mas deve-se ter clareza de que o primeiro é componente da vida e o segundo é componente da obra, sendo o autor-pessoa o que comumente é conhecido como autor empírico, ou seja, a pessoa de carne e osso que escreve, nesta pesquisa, o aluno que produz sua narrativa; já o autor-criador seria uma função estético-formal engendradora da obra. Sobre isso, Bakhtin assim se pronuncia:

\footnotetext{
O autor-criador nos ajuda a compreender também o autor-pessoa, e já depois suas declarações sobre sua obra ganharão significado elucidativo e complementar. As personagens criadas se desligam do processo que as criou e começam a levar uma vida autônoma no mundo, e de igual maneira o mesmo se dá com o seu real criador-autor (BAKHTIN, 2011, p. 6).
}

O autor-criador é parte inseparável da obra, mas não é o autor real e sim, uma entidade, uma espécie de consciência. Para Bakhtin, o autor, em seu estado criativo, deve se situar na fronteira do mundo que está criando. Neste sentido, o autor-criador é uma posição discursiva e faz um exercício de exotopia, ou seja, de distanciamento em relação ao texto. O princípio da exotopia é "o fato de uma consciência estar fora de outra, de uma consciência ver a outra como um todo acabado, o que ela não pode fazer consigo mesma" (TEZZA, 2001, p. 282). Tal princípio implica um distanciamento do autor-pessoa em relação àquilo que escreve; esse afastamento pode ser maior ou menor, dependendo do gênero discursivo adotado.

Em manifestos e em textos científicos, por exemplo, o autor-criador se aproxima mais do autor-pessoa; já no texto literário o distanciamento costuma ser maior; no caso da autobiografia o autor-pessoa e o autor-criador estão colados, mas precisa existir espaço para que o ato estético se concretize. Neste caso, "o discurso do autor-criador não é a voz direta do escritor, mas um ato de apropriação refratada 
de uma voz social qualquer de modo a ordenar um todo estético" (FARACO, 2005, p. 40).

Em Marxismo e Filosofia da Linguagem, no capítulo 9, em O Discurso de outrem, Volóchinov discute essa questão. O discurso citado é o discurso no discurso, a enunciação na enunciação, mas é, ao mesmo tempo, um discurso sobre o discurso, uma enunciação sobre a enunciação. A incorporação do discurso de outrem ajuda (o narrador) na formulação do próprio posicionamento social, e abre possibilidades para novos posicionamentos, permitindo ao narrador abordar os eventos narrados a partir de diferentes perspectivas. Essa modalidade de utilização do discurso de outrem é a mais próxima do que se entende por citação. É assinalada por marcas linguísticas como aspas, travessões e recursos gráficos. Em O que é o autor? (FOUCAULT, 1969, p. 276). Foucault afirma:

(...) poder-se-ia dizer que há, em uma civilização como a nossa, um certo número de discursos que são providos da função "autor", enquanto que outros são dela desprovidos. Uma carta particular pode ter um signatário, ela não tem autor; um contrato pode ter um fiador, ele não tem autor. Um texto anônimo que se lê na rua em uma parede terá um redator, não terá um autor.

A função autor é, portanto, nota-se que autoria para Foucault não é, como diria Guimarães Rosa, algo trivial, uma linguagem "de em dia de semana”. Ao contrário, para haver autoria é preciso escrever com certa singularidade e, para isso, dentre outras ações, é necessário reagrupar certos textos e relacioná-los entre si, pois "um discurso associado ao nome do autor não é uma palavra cotidiana, indiferente (...) que passa, imediatamente consumível"(idem).

Se para Foucault a função-autor está atrelada à obra, e esta, por sua vez, só existe quando publicada ou reconhecida por um grupo de pessoas, para Bakhtin (1986), a função autor está intimamente associada à assinatura do autor em textos que se inserem em um gênero discursivo específico dentro de uma esfera de circulação também específica.

O gênero, segundo Bakhtin, contém o tema, o modo composicional e o estilo e, ao elaborá-lo, o autor espera ser lido/questionado/interpelado por alguém. Percebese, assim, que cada estudioso oferece uma parcela de contribuição ao assunto aqui discutido. Quanto à questão da autoria, Foucault revela sua preocupação a respeito dela, e sobre isso ele afirma: "a escrita está atualmente ligada ao sacrifício, ao próprio 
sacrifício da vida; apagamento voluntário que não é para ser representado nos livros, pois ele é consumado na própria existência do escritor" (FOUCAULT, 1992).

Possenti defende a tese de que autoria é um conceito que não deve ser aplicado apenas a personalidades, isto é, em determinada relação autor-obra, nem tampouco, concebido como uma particularidade de uma pessoa específica. A autoria, para ele, tem forte relação com estilo, isto é, com aquele "traço pessoal", o que poderíamos chamar de singularidade. O autor sublinha que um texto escolar considerado mal-acabado e raso pode conter, além dos indícios de autoria, estilo.

Ainda segundo Possenti, se os alunos escrevem textos mal-acabados, muito se deve à escola, pois ela é "uma maquinaria destinada a excluir". Para que os estudantes passem a escrever melhor, ele afirma que é preciso "desescolarizar" a escola, reorganizar as atividades segundo critérios de relevância, com prioridade absoluta para as atividades de linguagem significativas, especialmente a leitura e a escrita, com especial destaque para as atividades de escrita, exatamente o objetivo com a presente dissertação. Ele defende que trabalhar a escrita a partir dos textos dos alunos em vez de ensinar regras descontextualizadas que não fazem sentido algum é muito mais produtivo. Aulas nas quais os alunos possam reescrever seus textos, pois, além de fazer mais sentido, promovem a autorreflexão e a construção de uma autoria.

A partir disso, ao conectarmos os conceitos à abordagem que pretendemos dar ao texto autobiográfico, situaremos, no próximo capítulo, as questões teóricas à esfera escolar, espaço onde produziremos as narrativas autobiográficas. 


\section{CAPÍTULO 2}

\section{O TEXTO AUTOBIOGRÁFICO NAS AULAS DE LÍNGUA PORTUGUESA}

O senhor olha para fora, e é isso sobretudo que não devia fazer agora. Ninguém pode aconselhá-lo e ajudá-lo, ninguém. Há apenas um meio. Volte-se para si mesmo.

Rilke, 2009

O texto autobiográfico pode ser estudado sob várias perspectivas. No presente capítulo, traçaremos os caminhos teóricos que embasam a análise. Trataremos desse gênero discursivo na esfera escolar, na aula de português no $7^{\circ}$ ano do Ensino Fundamental nos anos finais.

$\mathrm{Na}$ primeira seção, demonstraremos a relevância da produção escrita com textos autobiográficos; na segunda seção, abordaremos a esfera escolar, pensando no texto autobiográfico em relação ao desenvolvimento do aluno, quanto ao uso de estratégias de construção do texto narrativo como: progressão temática, ponto de vista do narrador textual. A leitura será o caminho para o contato com o gênero. $O$ aluno, por meio da leitura de trechos literários, perceberá aspectos do conteúdo temático e da estrutura composicional. Apresentaremos dez obras literárias possíveis para o trabalho com o gênero no ensino fundamental nos anos finais. 


\subsection{A autobiografia na esfera escolar}

Com a consciência de que todo signo se orienta de acordo com cada esfera da criação ideológica, já que cada campo de criatividade ideológica tem seu próprio modo de orientação para a realidade, tem-se então que a concepção de linguagem bakhtiniana, além de dar conta das coerções das esferas ideológicas, apresenta o signo como um fenômeno material. Isso ocorre porque as significações não estão estabelecidas e acabadas no sistema abstrato da língua, mas são constituídas na interação dos sujeitos, na vida real e cotidiana. Por isso, tratar do gênero autobiográfico na esfera escolar se faz tão necessário, uma vez que é onde acontece a materialização.

A seguinte citação de Bakhtin, fornece-nos alguns elementos para entendimento e argumentação sobre a importância da produção discursiva na esfera escolar:

A procura da própria palavra é, de fato, procura da palavra precisamente não minha, mas de uma palavra maior que eu mesmo; é 0 intento de sair de minhas próprias palavras, por meio das quais não consigo dizer nada de essencial. [...] A procura da própria palavra pelo autor é, basicamente, procura do gênero e do estilo, procura da posição de autor (2011: 385).

Paralelamente ao objetivo de adquirir e manipular conhecimentos, ou seja, estar preparado para responder questões conceituais, a autoria é parte constitutiva da meta de formação básica na escola que se preocupa com a formação integral de seus sujeitos. Ao buscar um ensino significativo, direcionar o aluno para que ele encontre a própria palavra é um desafio.

Apresentar o gênero por meio de trechos de narrativas tem uma materialidade sugestiva, e mostra-se mais produtivo do que uma lista de características e passos para seguir, pois uma produção não se faz no vazio, é preciso recorrer a uma memória discursiva, ou seja, "alguma coisa criada é sempre criada a partir de algo dado (a linguagem, o fenômeno observado da realidade, um sentimento vivenciado, o próprio sujeito falante, o acabado em sua visão do mundo, etc.). Todo o dado se transforma em criado" (BAKHTIN, 2011:326).

A concepção de autoria em Bakhtin implica o caráter heteroglóssico da linguagem - 0 fato de nela se conjugarem vozes sociais, falares e registros de todo tipo (que expressam valores e interpretações do mundo). Trabalhar com esse material 
heterogêneo na escola é essencial para o percurso de construção da autoria. Existe a possibilidade de que defendam que não se ensina e não se aprende a ser autor, mas no presente trabalho não creditamos que é um dom natural ou uma facilidade, trata-se a escrita como um aprendizado específico que não se limita a uma autoria de nível literário ou filosófico, estamos na esfera escolar, onde a construção é possível e viável, pois há uma metodologia capaz de orientar a construção, que é o que se busca compreender quando da elaboração da sequência didática. Há, certamente, etapas e nuances na construção da autoria.

Considerando os gêneros como estratégia de ensino, tendo consciência da dimensão social nas esferas (onde, quem e para quem produz?) e dimensão linguística (composição, organização, estilo) em estreita relação, os textos reais têm muita vida em si; e por mais que sigam normas (estabelecidas nas esferas nas quais se originam), não podem ser amarrados a ponto de perderem suas peculiaridades.

Dada a característica de alteridade dos textos autobiográficos, a compreensão tem um papel essencial nesse processo: aqui a resposta ativa é exigida e requer uma possibilidade de resposta; para construir sentido, deve haver envolvimento no acontecimento discursivo, assim, entende-se o que é a escola. Rojo (2007) define a escola como instituição social que apresenta uma esfera de atividades com funcionamento próprio, além de afirmar que o conteúdo temático da grande maioria dos enunciados escolares se liga ao objeto de ensino elementarizado, objetivado nos discursos do livro e do(a) professor(a), quase nunca centrado no aluno.

Nesse sentido, a autobiografia consegue escapar de um conteúdo temático ligado ao objetivo do ensino elementarizado instaurado, e liga-se a uma nova concepção de ensino de língua escrita e leitura que enxerga a importância na aprendizagem significativa, em que o aluno é o protagonista na construção de seu aprendizado.

O papel das aulas de português é munir os alunos de conhecimentos para que desfrutem com sucesso nas diversas situações de comunicação, Dolz e Schneuwly (2004) colocam o gênero discursivo, justamente como o aparato necessário para o agir nas produções textuais. Bakhtin, afirma que a comunicação verbal seria quase impossível se não existissem os gêneros do discurso. Assim, para refletir sobre o ensino e a aprendizagem da escrita do texto autobiográfico, e refletir sobre o ensino 
de língua materna, é necessário que tenhamos clareza sobre a teoria dos gêneros discursivos.

Diante da árdua tarefa de ensinar a produção escrita, é importante que sejam criado oportunidades para que o aluno escreva sobre seu contexto e sobre fatos que domina. Nesse sentido, o gênero autobiografia na esfera escolar permite uma elaboração textual, partindo da realidade do aluno, em que ele pode contar situações de sua vida, por meio da organização de um conteúdo temático, recorrendo a um estilo e à construção composicional de um gênero.

A forte presença do "eu" na autobiografia remete a Bakhtin (2012), quando apresenta reflexões sobre o ato responsável, pois, ao escrever, o aluno analisa seus atos e assume "responsabilidade" sobre eles ao transmiti-los por meio da escrita. Por isso, a autobiografia é uma forma de reviver, de assumir suas ações, "é um pensamento que age e se refere a si mesmo como único ator responsável" (BAKHTIN, 2012, p. 102). Esse gênero se organiza por meio de uma narrativa centrada no sujeito que a produz, reservada as suas reflexões e experiências particulares e é a expressão de sua autonomia, "visto que a minha atitude é essencial para o mundo" (BAKHTIN, idem, p. 103)

É prazeroso relembrar e narrar acontecimentos envolvendo a singularidade de cada um, a linha cultural particular e a diferenciação dentro de uma organização social. O autor da autobiografia escreve sobre sua vida considerando o conhecimento que tem de si próprio, de acordo com a história que tem na memória que é entrecruzada com muitas outras histórias. É o olhar do autor sobre sua vida e a influência do outro na construção de sua história. Sendo assim, "cada um tem razão no seu próprio lugar, e tem razão não subjetivamente, mas responsavelmente. Do meu lugar único, somente eu-para-mim-mesmo sou eu, enquanto todos os outros são outros para mim" (BAKHTIN, 2012, p. 104). Os momentos narrados pelo autor podem ser comprovados por outras pessoas, por documentos ou provas materiais, mas são relatados sob a interpretação pessoal do autor, sua história está em suas mãos.

Com isso a autobiografia escolar é uma atividade proposta para que o aluno exercite a estruturação de um relato de suas vivências, direcionada para interlocutores reais, ou seja, para a professora de forma mais direta, mas podendo também direcionar para os colegas de sala, de outra escola, familiares ou comunidade. 
Para iniciar o trabalho com o gênero autobiografia, o primeiro momento é que o aluno reconheça que o texto autobiográfico é uma prática social de uso efetivo da língua, com finalidade e construído a partir da intencionalidade do autor de apresentar sua história de vida para interlocutores específicos. O contato com narrativas do gênero contribui para que identifique suas características peculiares e tenha um direcionamento para sua escrita, não para segui-lo fielmente, como diz Geraldi (1997), mas ter um parâmetro de escrita:

Compreender a distância que separa o texto que produzimos de outros textos produzidos por outros só torna a diferença uma forma de silenciamento quando tais textos são vistos como modelos a seguir, e não como resultados de trabalhos penosos de construção que deveriam funcionar para todos nós como horizontes e não como modelares. Repeti-los em nada os lisonjeia. Tê-los em mente pode nos ajudar a julgar a relevância de nossos textos (GERALDI, 1997, p. 165).

O aluno compreenderá os aspectos do gênero por meio da leitura de textos que o representem, "reconhecendo o contexto social, histórico e ideológico que o circunda, conferindo sua esfera de produção, seu conteúdo temático, seu estilo e sua construção composicional" (COSTA-HÜBES, 2014, p. 28) para, posteriormente, planejar sua escrita, averiguando a discursividade que norteará sua produção.

Para Bakhtin, quanto melhor dominamos os gêneros tanto mais livremente os empregamos, tanto mais plena e nitidamente descobrimos neles a nossa individualidade, refletimos de modo mais flexível e sutil a situação singular da comunicação; em suma, realizamos de modo mais acabado o nosso livre projeto de discurso. Portanto, para trabalhar com o gênero autobiografia, por exemplo, na sala de aula, é preciso antes que o aluno tenha acesso a diversos textos desse gênero para, só então iniciarmos um processo de reflexão sobre os elementos que o constituem, e é justamente esse percurso que está descrito no próximo capítulo, no qual a sequência de atividades e as reflexões em torno delas são apresentadas.

Os alunos não terão dificuldades em relatar sobre a sua própria vida, ou seja, relatar aspectos que julgam destacáveis em suas trajetórias, já que o adolescente do século XXI está a todo o momento fazendo isso. São jovens que vivem no meio digital expondo suas vidas nas redes sociais. Os relatos de acontecimentos ocorrem o tempo todo, em forma de postagens de textos, fotos e/ vídeos, no Facebook, no Instagram ou no Snapchat. 
Não nos aprofundaremos nisso, mas as postagens realizadas nas redes sociais não são, obrigatoriamente, escritas autobiográficas, porém, são, em grande medida, relatos de ações, que fazem parte do cotidiano dos adolescentes na atualidade. $A$ partir da percepção de que esses jovens em alguma medida já têm experiência com o relatar, deve-se ter em mente que, para o ensino de autobiografia os alunos antes de se tornarem autores de autobiografias, devem ser leitores do gênero. O leitor de um texto autobiográfico "se envolve no processo: [pois temos trajetória de] alguém pede para ser amado, para ser julgado" (LEJEUNE, 2008, p. 73), e essa será a porta de entrada para o mundo da autobiografia para os jovens sujeitos desta pesquisa, a leitura de textos autobiográficos.

O objetivo é apresentar as características do gênero, em relação ao seu conteúdo temático, composicional e estilístico, mas para que isso se desenvolva, bases conceituais sólidas precisam ser estruturadas. Quando se fala em autobiografia, automaticamente há referência à temática do "eu", e mais, à identidade do autor que também é personagem. Para Lejeune, a identidade do "eu" é assegurada por meio do pacto autobiográfico, e para Arfuch com o valor autobiográfico, mas que adiantamos trata-se de uma espécie de contrato entre autor/leitor, cujo fiador seria o nome próprio do autor.

Trazendo para o universo dessa pesquisa, o pacto é estabelecido entre cada um dos alunos de $7^{\circ}$ ano. Acredita-se que isso também é impactante no processo de ensino e aprendizagem, pois alunos que são adolescentes além de enfrentarem as significações de sua própria vida, firmam um contrato de sinceridade com um destinatário.

A partir de Bakhtin, entende-se que é no processo de recriar a história de vida que o sujeito narrador tem oportunidade de se ressignificar e de ressignificar a sua experiência de vida, trazendo elementos que são relevantes para a sua constituição como um sujeito. De alguma maneira, terão a percepção do quanto o contexto em que estão inseridos interfere em suas vidas, localizando um tempo e um espaço específicos. A autobiografia é um gênero importante para formar sujeitos mais conscientes de seus lugares no mundo e mais conscientes de si. Segundo Ricoeur (1991, p. 30), "dizer si não é dizer eu. O eu se põe ou é deposto. O si está implicado a título reflexivo nas operações cuja a análise precede a volta para ele próprio". 
Voltando para Lejeune (2008), o autor discute quatro aspectos importantes que são constitutivos desse gênero:

(a) a forma da linguagem;

(b) o assunto tratado;

(c) a situação do autor e

(d) a posição do narrador.

Em relação à forma da linguagem, o autor propõe que a autobiografia deve ser composta em prosa (ainda que, posteriormente, tenha revisto esse posicionamento radical, uma vez que a autobiografia poderia vir em forma de poesia, por exemplo, como observado na obra de Helena Kolody, que será abordada a seguir). Mas para a pesquisa, o que interessa é perceber que existem alguns elementos estruturais dos quais os alunos precisam ter clareza, para que aprendam e sejam capazes de produzir uma autobiografia, o que aborda o Capítulo 3, em que veremos aspectos metodológicos para o desenvolvimento do trabalho.

Os alunos, ao produzirem uma narrativa autobiográfica, abordam aspectos da vida íntima, pois ao falarem sobre si mesmos e sobre os eventos que os cercam, será possível entender mais sobre quem são esses alunos. Mas, não é só sobre o "eu" que teremos acesso nos enunciados autobiográficos, mas também sobre o seu lugar social, sobre o seu entorno, alcançando até a compreensão da forma como esse meio o influencia. Busca-se que, a partir da análise de autobiografia, seja possível discutir não só os fatos em si, mas a experiência, os sentimentos que perpassam certos acontecimentos típicos de um jovem de 12 anos. É possível que se alcance um mapa dos processos históricos, econômicos, sociais e culturais nos quais estão envolvidos esses alunos-autores.

Em relação à posição do narrador, volta-se ao conceito de pacto já apresentado anteriormente. Aqui reside a noção de que há uma compreensão pré-existente ao ato de leitura sobre a estrutura composicional do gênero e a sinceridade e veracidade dos fatos ali apresentados. Quem escreve a autobiografia está sendo sincero consigo e com o outro. Além de estar exercendo a sua cidadania, pois escrever é construir a sua própria voz, é firmar um compromisso com um dizer que se completa socialmente, escreve-se para o outro e com o outro. Trata-se de uma reflexão complexa, no texto autobiográfico, "efetivamente, para além do nome próprio, da coincidência "empírica", 
o narrador é outro, diferente daquele que protagonizou o que vai narrar: como se reconhecer nessa história, assumir faltas, se responsabilizar por essa outridade?" (ARFUCH, 2010, p. 54).

Ao fazer o retrospecto da vida, ainda que se trate de poucos anos, há um (re)descobrimento do passado; o sujeito, esse alunos, que estão em um processo de construção de suas identidades que podem ser caracterizadas por "conflito, contestação e uma possível crise" (WOODWARD, 2000, p. 12), têm aqui a oportunidade, de alguma forma, de organizar suas vivências, e até serem donos da escolha e selecionar o que vão mostrar e o que vão esconder. Tratar da questão do narrador em primeira pessoa é a base para discutir a importância do ensino de autobiografia nas aulas de português, como descrito no Capítulo 3.

É uma possibilidade de subjetivação da vida, contudo, pouco individualista, pois segundo Petit (2013) "o mais íntimo tem a ver com o mais universal, e isso modifica a relação com os outros". Moita (1995) considera a pesquisa autobiográfica a metodologia com potencialidades de diálogo entre o individual e o sociocultural, pois "põe em evidência o modo como cada pessoa mobiliza seus conhecimentos, os seus valores, as suas energias, para ir dando forma à sua identidade, num diálogo com os seus contextos" (p. 113), razão pela qual os estudos autobiográficos podem ser entendidos como referentes a vidas inseridas em um sistema em que a pluralidade de expectativas e de memórias é o corolário da existência de uma pluralidade de mundos.

A função social do gênero autobiografia é tornar público algo particular, ou seja, mostrar e divulgar às outras pessoas a história de vida do sujeito que se propôs a escrevê-la (BAKHTIN, 2011). A relevância de uma escrita autobiográfica é dialética, faz sentido para o narrador-personagem e para o seu interlocutor, pois uma comunidade pode vivenciar as experiências vividas por seu autor e, desse modo, ampliar a percepção que tem de um determinado universo cultural. 


\subsection{A literatura e o eu}

Temos clareza de que o leitor autobiográfico, ao produzir sentidos sobre o gênero lido, traz os acontecimentos relatados para a sua própria vida, refletindo sobre ela. Por isso, este estudo visa a ser mediador nessa descoberta da leitura autobiográfica, levando para os alunos possibilidades de familiarização, para que consigam, durante a produção, a autorização para a abordagem desses temas variados. Cada leitura foi avaliada segundo suas paixões e curiosidades, salientado a importância, destacada por Petit (2013, p. 29), de que entre todas as obras, as de hoje e de ontem, alguma dirá algo de particular ao leitor, criando uma atmosfera de intimidade, que percorrerá a sequência de atividades que será tratado no capítulo seguinte.

Petit defende o caráter social da leitura, a importância para a constituição dos sujeitos, e acredita-se aqui que a leitura deve ser o primeiro momento no ensino e no aprendizado de autobiografia:

A leitura pode contribuir, desse modo, para a elaboração de uma identidade que não se baseia no mero antagonismo entre eles e nós, minha etnia contra a sua, meu clã, meu povo ou meu "território" contra o seu. pode ajudar a elaborar uma identidade em que não se está reduzido apenas a laços de pertencimentos, mesmo quando se tem orgulho deles, e levar a construção de uma identidade plural, mais flexível, mais adaptável, aberto ao jogo e ás mudanças (PETIT, 2013: 55).

Houve preocupação com a seleção de textos, pois assim como Petit (p. 43-44) uma vez que o espaço criado pela leitura não é uma ilusão, é um espaço psíquico que é próprio da elaboração das posições dos sujeitos. Os leitores são ativos, nesse caso, a tensão é constante entre o que se lê e o que se vive ou viveu. A autora inclusive chama atenção para o fato de a adolescência ser o período mais sensível nesse aspecto, pois trata-se de uma época "que o mundo exterior é percebido como hostil, excludente, e no qual o jovem se vê às voltas com um mundo interior inquietante". O interesse e a identificação com essas leituras é o que irá munir o aluno de conceitos e percepções teóricas, que o direcionarão no momento da produção escrita.

Assim, segue uma lista com dez obras autobiográficas selecionadas a partir de dois eixos: 
(a) os clássicos;

(b) os contemporâneos.

Nessa fase da pesquisa de títulos autobiográficos, observaram-se autobiografias de pessoas célebres que citavam as mesmas obras, remetendo à célebre obra de Ítalo Calvino, quando ele afirma que: "Estou relendo... " e nunca "Estou lendo... "; Segundo Calvino (2007), isso acontece pelo menos com aquelas pessoas que se consideram grandes leitores. Por isso, foram classificadas como clássicas as obras que sempre apareciam atreladas à autobiografia e contam trajetórias de escritores que fazem parte do cânone literário brasileiro.

Infância, de Graciliano Ramos, publicada em 1945, é uma obra de referência ao se tratar de autobiografias, presente na lista de leituras clássicas do gênero. Apresenta uma leitura exigente devido à linguagem, o que torna a obra complexa para os alunos devido à idade e à maturidade. A seleção de trechos exigiu que a leitura fosse feita de forma compartilhada. No livro, o narrador, em primeira pessoa, conta sua infância no sertão de Pernambuco, recorda a primeira fazenda em que viveu, onde plantava abóbora. O narrador fala sobre as várias mudanças e sobre os irmãos. O menino sofre, apanha muito e é repreendido severamente, sofrendo em casa e na escola. Para estimular a leitura dos alunos, é interessante contextualizar e focar no amadurecimento da criança exposta como protagonista. $\mathrm{O}$ autor expõe a forma com que lidou com a dor e a opressão vivida dentro de casa. Essas discussões abrem possibilidade de tratar de assuntos delicados em suas autobiografias, como o relacionamento com os pais e a agressividade familiar.

Baú de Ossos, do mineiro Pedro Nava, publicada em 1972, traz como subtítulo Memórias I. O narrador conta os acontecimentos vividos por ele e por sua família, parentes, mesmo os mais distantes na primeira parte, denominada Setentrião. $\mathrm{Na}$ segunda, Caminho Novo, fala sobre a família de sua mãe; na terceira, Paraibuna, fala da vida de seu pai e um pouco de sua fase inicial da infância. Na quarta e última parte, Rio Comprido, a narrativa se encerra quando ele tem aproximadamente oito anos e sofre o trauma da morte do pai e a partida da mãe, já no Rio de Janeiro. A leitura é densa e complexa, porém rica. Contudo, para a leitura integral não é adequada aos alunos de $7^{\circ}$ ano, que não apresentam domínio vocabular suficiente para 
compreensão individual dessa obra. No entanto, a seleção de alguns trechos com uma linguagem mais coloquial pode ser uma opção para trabalhá-la em sala.

Duas obras de José Lins do Rego aparecem na categoria dos clássicos pois são mencionadas como autobiográficas, de modo que o material traz seus textos desde o sexto ano. Menino do Engenho, 1932 e Meus Verdes Anos, 1956, são duas obras com a temática da infância por meio de figuras interessantes, que foi o mote para trazê-las como possibilidade para tratar do gênero em questão. Em Menino do Engenho, acredita-se que o que mais pode chamar atenção dos alunos é a figura do avô e os acontecimentos típicos da infância, o que facilmente estabelece uma ligação entre os alunos e a obra.

O narrador é a personagem, Carlinhos, que, aos quatro anos, presencia uma cena terrível, em que seu pai assassina sua mãe com um tiro e vai viver no engenho; acompanhar essa transformação é interessante, pois são muitas descobertas, as quais possam interessar aos alunos.

Em Meus Verdes Anos tem-se a abordagem de temas mais densos, como o preconceito racial e a descoberta da sexualidade, que foram os que chamaram mais atenção dos alunos no momento da escolha. A história diz sobre a criança "largada" dentro da sua própria família, questão de extrema importância para os alunos que, constantemente, verbalizam em sala de aula sobre suas relações familiares.

Essa força estranha: a trajetória de uma autora, de Ana Maria Machado (1996), relata sua história, os caminhos que a levaram a seguir a escrita como profissão. O que mais chama atenção é o amor com que ela fala dos livros, demonstra um real encantamento com as palavras, e um respeito ímpar pelas obras. Portanto, traz uma temática que pode envolver os alunos e ser capaz de despertar neles o gosto pela leitura, percebendo o quanto aventuras literárias são significativas e transformadoras. Não foram incluídos trechos dessa obra na sequência didática, contudo, aparece como uma excelente possibilidade para a leitura compartilhada em aula. A autora é muito conhecida dos alunos devido aos títulos infanto-juvenis, por isso a escolha no eixo dos clássicos.

Entende-se como contemporâneos livros mais recentes, mas, principalmente, que abordam temáticas mais próximas dos alunos, que mantêm um vocabulário mais coloquial e tornam a aproximação com a autobiografia mais espontânea, como é o 
caso de Depois daquela viagem: diário de bordo de uma jovem que aprendeu a viver com Aids, de Valéria Piassa Polizzi (1997) que teve ampla aceitação do público jovem com mais de 300 mil exemplares vendidos e traduzida para vários idiomas como o italiano, alemão e espanhol, sendo trabalhada em diversas escolas, tanto em aulas sobre sexualidade quanto em aulas de leitura. A escolha se deve por se tratar de uma temática essencial para jovens dessa fase, é um livro com a temática do hoje, tratando de um assunto estigmatizado e muitas vezes pouco trabalhado no Ensino Fundamental II. A narrativa conta a autobiografia de Valéria, que narra sua história em primeira pessoa. Por volta dos 16 anos, ela descobre que está com a doença denominada AIDS, isto é, Síndrome da Imunodeficiência Adquirida. Em linguagem coloquial e com muita propriedade, a autora relata suas vivências com amigos e familiares, abordando o despertar da sexualidade e a angústia diante da descoberta da doença. Traz à tona, numa linguagem clara e simples, questões que permitem ao jovem leitor se identificar com a narradora-personagem.

Outro título atual e que desperta grande interesse nos alunos é Eu sou Jack, o estripador: a autobiografia do mais famoso assassino da história, James Carnac, traduzido para o português por Jorge Ritter (2016). Originalmente publicada em inglês (2012), Eu sou Jack, o estripador chegou ao Brasil em 2016. A seleção dessa obra se deve por ser pouco conhecida dos alunos e trazer uma narrativa de um personagem aterrorizante, tema de interesse dos alunos de $7^{\circ}$ ano que, em geral, têm entre 11 e 13 anos. Pensando nas turmas onde o corpus foi coletado, pode-se afirmar que é uma temática pela qual são aficionados, pois eles foram apresentados ao gênero terror no $6^{\circ}$ ano, durante as aulas de leitura e produção textual, momento em que esse tema despertou muito interesse. Assim, mesclar os gêneros aproxima os leitores. Em síntese, a narrativa remonta um caso policial que repercutiu mundialmente, quando em 1888, mulheres foram brutalmente assassinadas em um bairro londrino. O misterioso assassino, que ganhou a alcunha de Jack, o estripador, tornou-se conhecido em todo o mundo e nunca foi identificado ou preso pelos crimes. A polícia de Londres chegou a receber cartas e denúncias anônimas, mas nada foi conclusivo. A obra em questão apresenta um ponto de vista inovador, pois destaca o olhar do assassino com as suas "justificativas", os caminhos que o levaram a se tornar o famoso Jack. A autobiografia ficcional de Jack, o estripador apresenta um novo suspeito, a partir do manuscrito encontrado por volta de 1930 entre os pertences de 
um homem. Narrado em primeira pessoa, Jack inicia sua história pela sua infância, trazendo motivações e algumas descrições sobre os crimes, recheado de detalhes de total precisão. Ainda que não se tenha certeza de que tal fato ocorreu realmente, a hipótese de um texto do verdadeiro Jack é o que intriga os estudantes.

$\mathrm{Na}$ fase de levantamento bibliográfico, o destaque foi com a Sinfonia da Vida, de Helena Kolody (1997), e ao trazê-lo, mesmo sendo um texto poético autobiográfico, abriu-se uma nova possibilidade para abordar o gênero autobiográfico sob um novo aspecto, por isso a necessidade de que uma obra diferenciada, que abrisse novos horizontes estivesse nessa lista. Os poemas são acessíveis aos alunos, e podem servir para trabalhar a questão da subjetividade, aspecto também importante no trabalho com a autobiografia. O início do livro traz um texto em prosa autobiográfico, com uma série de revelações feitas pela própria autora, o que propicia uma espécie de incentivo para a leitura dos poemas que seguem uma ordem cronológica no livro.

Outra obra desse mesmo eixo que trata da (des)construção da ideia ingênua de que a infância é sempre feliz e traz uma série de textos curtos autobiográficos é 0 mito da infância feliz, de Fanny Abramovich (1983). Essa obra apareceu como uma possibilidade para abordar o gênero com os alunos pois o título por si só chama atenção, uma vez que os alunos no $7^{\circ}$ ano tratam dos mitos gregos no módulo 7 da apostila 1 do Sistema Anglo de Ensino.

As narrativas que compõem a obra são enriquecedoras, e o livro reúne autobiografias de diversas pessoas, desde escritores célebres até professores. $\mathrm{Na}$ verdade, na nota introdutória e no prefácio, a organizadora fala que solicitou qualquer tipo de texto, não especificamente autobiografias, contudo grande parte dos 14 textos são autobiográficos. Nos trabalhos já publicados sobre o gênero, a mais citada é a de Bartolomeu Campos Queiroz, que, em primeira pessoa, constrói uma autobiografia sensível, em que narra principalmente a relação com os pais, com a natureza e com Deus. Trata dos dilemas até os dez anos, que é justamente a fase que os alunos desse estudo acabam de encerrar, mas suas memórias ainda moram nessa fase.

Por fim, para completar as cinco obras do eixo do contemporâneo temos Léo, o pardo, de Rinaldo Santos (2006). Aqui o escritor mineiro faz uma espécie de homenagem às pessoas que o ajudaram na sua trajetória de vida, dando espaço para o valor do outro. São lembranças de sucessos e frustrações contadas em primeira pessoa de uma forma singela e franca, com um vocabulário simples e acessível, 
assemelha-se a uma conversa devido à coloquialidade, é uma obra humana por excelência. Este livro foi selecionado pelo programa Literatura para todos do Ministério da Educação, e em 2007 foi distribuído nas escolas da rede pública. É uma narrativa contemporânea que percorre toda a infância e a juventude do autor, inclusive como

estudante da Universidade de São Paulo. É "gente como a gente", não se trata de um escritor de renome que relata sua trajetória, o que aproxima a experiência de leitura da produção que será realizada posteriormente. Léo sonha em ser cineasta, é um sonho ambicioso, ele tem essa dimensão, e a partir daí vai relembrando casos de seus antepassados escravos e fala sobre o preconceito por ser pardo.

No eixo do contemporâneo, abarcaram-se grandes temáticas, as quais levaram os alunos a apreciar a diversidade dos textos. A decisão por esses dois eixos ocorreu para que eles pudessem compreender que entre os escritos de ontem e de hoje, daqui ou de outros lugares, certamente haverá alguns que terão algo a lhes dizer em particular. E fazê-los descobrir a voz singular de diversas pessoas, desde um estudante da periferia paulista até um menino de engenho, e que todos podem oferecer grandes histórias de vida.

\subsection{A escrita e a reescrita}

Bakhtin em Estética da Criação Verbal (2011), comenta que não se pode delimitar a linguagem em atos de fala individuais, muito menos isolá-la em um sistema linguístico. Em outras palavras, a língua não se faz apenas por sistema linguístico (embora esse aspecto faça parte de sua constituição), muito menos pela criação individual, "solitária".

Ao considerar o enunciado produto da interação, Bakhtin e o Círculo (2009) inserem na comunicação verbal a ação dos participantes - os interlocutores -, os quais são constitutivos do próprio enunciado, determinando o "como" e o "porquê" do querer-dizer. Nesse âmbito, o locutor dirige a sua fala para o ouvinte, que não será ouvinte passivo, mas responderá ao outro, que logo lhe dará nova resposta e, assim, os sentidos serão construídos. Tal ação acontece por causa do fenômeno denominado dialogismo, fator, segundo a teoria bakhtiniana, indispensável para a formação da linguagem.

Conforme já dito, a enunciação é de natureza social por ocorrer em meio à interação e apresentar um caráter dialógico. Desse modo, pode-se concluir que o 
dialogismo é constitutivo da linguagem e aparece em qualquer situação. Sobre isso, Bakhtin (2002) pontua que "a orientação dialógica é naturalmente um fenômeno próprio a todo discurso. Trata-se da orientação natural de qualquer discurso vivo" ( $p$. 88). Nesse aspecto, a reescrita, enquanto prática social da linguagem, é um processo dialógico reflexivo, ou seja, um diálogo carregado de compreensão ativa com a percepção do "eu" sobre o outro e o entendimento das construções de sentidos que aparecem nas práticas sociais. Em outras palavras, a reescrita é um momento de reflexão que envolve os discursos de outrem, a fim de compor as ideias próprias ou ainda novos sentidos. Para que os alunos materializassem tal ato, foi definido que trabalhassem em dupla.

Desse modo, verificou-se, também, na reescrita a presença dos construtos teóricos que, segundo Bakhtin e o Círculo, compõem o dialogismo, isto é, a atitude responsiva; a compreensão ativa; a exotopia; os atos estético e ético.

A compreensão ativa e a atitude responsiva ativa estão ligadas à constituição do aluno-autor, o qual se desenvolve na prática reflexiva da reescrita. Nota-se, então, a construção da autoria, conforme Bakhtin, caracterizada pela atitude criadora do aluno, advinda da compreensão ativa. Os atos estético e ético significam a organização das ideias axiológicas em determinado gênero do discurso. Na prática de reescrever, o aluno preocupa-se em organizar as suas apreciações valorativas, tendo em consideração as particularidades do gênero e, ainda, buscará escrever de maneira que o seu destinatário compreenda.

O excedente de visão que o aluno tem sobre a sua própria produção e a produção do colega faz com que ambos compreendam o que é necessário melhorar. A partir disso, ele poderá construir um novo olhar, ou seja, um olhar outro a respeito do próprio texto. Esse movimento só é possível, com uma atividade que dê suporte para os alunos superarem suas dificuldades, trabalhando com suas necessidades. Compreende-se que, desde a primeira versão da produção escrita, o aluno inicia o seu caminho de desenvolvimento para a constituição de um sujeito-autor, de modo que no momento da reescrita o trabalho seja mais reflexivo, pois ali supõe-se que o aluno é consciente e perceptivo do que precisa ser melhorado em seu texto, a partir de sua própria observação ou até de indicações feitas pelo professor ou outros colegas, como demonstrado no Capítulo 3, em que há a explicitação da atividade de reescrita elaborada, em que os próprios alunos foram os revisores dos colegas. 
Para trabalhar com reescrita, é necessário assumir uma concepção de linguagem como um trabalho que acontece na interação social, porque os sujeitos vão se apropriando da linguagem ao se constituírem como locutores, junto aos seus interlocutores; a apropriação da linguagem implica um trabalho do sujeito, o que significa que há um movimento do sujeito e uma recriação da linguagem em cada situação de interação; cada interação é um momento novo de produção linguística, portanto, revisar o texto do colega também é uma produção linguística.

Antes de findar a parte teórica da presente dissertação, faz-se necessário o breve percurso das etapas básicas de uma produção textual, para que assim, as etapas da atividade proposta fiquem mais claras.

A construção de um texto deve ser considerada como uma atividade recursiva, ou seja, trata-se de um processo constituído de etapas que, por não serem estanques, necessitam ser bem definidas e respeitadas para que, ao final, o resultado seja um texto robusto e não um conjunto de frases desprovidas de sentido. Assim, a ação de produção de um texto tem início com o planejamento, momento em que o indivíduo projeta o que será escrito. Para que o aluno consiga cumprir a etapa, é imprescindível que os dados do contexto de produção estejam claros e bem desenvolvidos.

O segundo momento desse processo é a escrita, instante no qual o aluno-autor textualiza o que foi projetado, registra o que foi planejado. Pereira (2010) assinala que, sendo a escrita uma prática social que engloba "todos os parâmetros de ordem social e individual", o indivíduo revela, nesse momento, além dos fatores relacionados às condições de produção que lhes foram oferecidas, os fatores que dizem respeito "ao processamento cognitivo ativado no momento da produção" (idem, p. 176).

A partir dessas etapas que são comuns a qualquer produção escrita, tem-se possibilidades. Para alguns o trabalho se encerra, para outros o momento de revisão que, segundo Antunes (2003, p.56) é o momento de "decidir sobre o que fica, o que sai, o que se reformula" no texto. Vale ressaltar que essa atividade não pode e nem deve ser concebida como a correção do texto, como ação de detectar erros e consertá-los ou anulá-los, visto que tal etapa constitui um instante de reflexão, que pode inclusive ser realizada como um exercício de análise do texto. A concepção de revisão aqui não é tarefa do professor, pois o aluno-autor pode e deve revisar seu próprio texto. Além disso, é possível também que esse exercício reflexivo seja 
realizado em pares ou em grupos, atividade essa que constitui a "revisão coletiva", tipo de revisão adotada para esta atividade.

Finalmente, a reescrita. Etapa compreendida como o instante da reconstrução do texto, tendo em vista as considerações apresentadas ao final da revisão. Essa etapa não é simplesmente escrever o texto novamente ou escrever um novo texto, mas (re)pensar, (re)planejar e (re)textualizar o que está sendo produzido. A realização do trabalho com a produção textual enquanto processo composto por etapas tem sido um dos meios que se revelam eficazes no processo de ensino-aprendizagem da língua, pois possibilita aos indivíduos a reflexão sobre a língua, já que, além de planejar e escrever, eles terão que rever seus textos de maneira crítica, sendo capazes de identificar problemas e buscar estratégias para solucioná-los. 


\section{CAPÍTULO 3}

\section{PROPOSTA TEÓRICO-METODOLÓGICA DE ATIVIDADE DE PRODUÇÃO DE TEXTO AUTOBIOGRÁFICO NO 7ํANO}

Sua carta amável que os acompanha não deixou de me esclarecer
alguma insuficiência que senti ao ler seus versos, sem, no entanto, ser
capaz de designá-la pelo nome.

Rilke, 2009

O presente capítulo trata dos procedimentos teórico-metodológicos das atividades de leitura participativa e de produção textual referentes ao texto autobiográfico para $07^{\circ}$ ano do Ensino Fundamental II. A questão central é o mapeamento da esfera de elaboração e aplicação das atividades. Por fim, trata-se aqui das três etapas da atividade: a leitura, a elaboração e a reelaboração.

\subsection{O espaço da escrita nas aulas de português em escola particular}

No Ensino Fundamental II, a proposta pedagógica do Colégio Anglo21 foca os conteúdos e as áreas de forma global e integrada, a preocupação para que haja o contínuo aprimoramento da leitura, interpretação e produção de textos, da apropriação de conhecimentos que permitam ao aluno desenvolver uma visão crítica acerca do mundo e da sociedade em que está inserido.

Situado no bairro Alto da Boa Vista, atende à classe média alta da zona sul da 
cidade de São Paulo. O prédio pertencia ao tradicional Colégio Doze de Outubro, que tem mais de 50 anos de história. O edifício foi idealizado por João Batista Vilanova Artigas em 1962, tendo sido tombado como patrimônio artístico da cidade de São Paulo. As características da edificação são típicas da obra desse renomado arquiteto, a larga escala de concreto aparente e amplos espaços internos.

Em 2016, o Colégio Anglo21 teve seu primeiro ano letivo sob a gestão do Sistema Anglo de Ensino. São mais de 800 escolas associadas, em torno de 400 mil alunos, e é a primeira escola própria do Sistema. O quadro de funcionários e professores foi quase que integralmente renovado com a nova gestão, o que causou impacto na comunidade, que vivenciou uma mudança brusca e completa dentro dos mesmos corredores da escola antiga. Novos tempos e novas vivências se instalaram entre as grandes paredes de concreto.

Os alunos são convocados a trocar, discutir, refletir e desenvolver posturas responsáveis, solidárias e participativas, pois se tem convicção de que a função primordial da escola é desenvolver as capacidades comunicacionais. A grande busca é encontrar sentido e relação entre o estudado teoricamente e a vida real.

A disciplina Língua Portuguesa conta com três frentes: Leitura, Estudo da Língua e Produção Textual. O material apostilado para o Ensino Fundamental II segue um padrão, são 4 cadernos com 50 capítulos, em média. A apostila do $7^{\circ}$ ano, elaborada por Ricardo Silva Leite, Leita Rensi e Marisa Sodero Cardoso, reúne 48 capítulos. 


\section{Figura 1: Capa e folha de rosto}

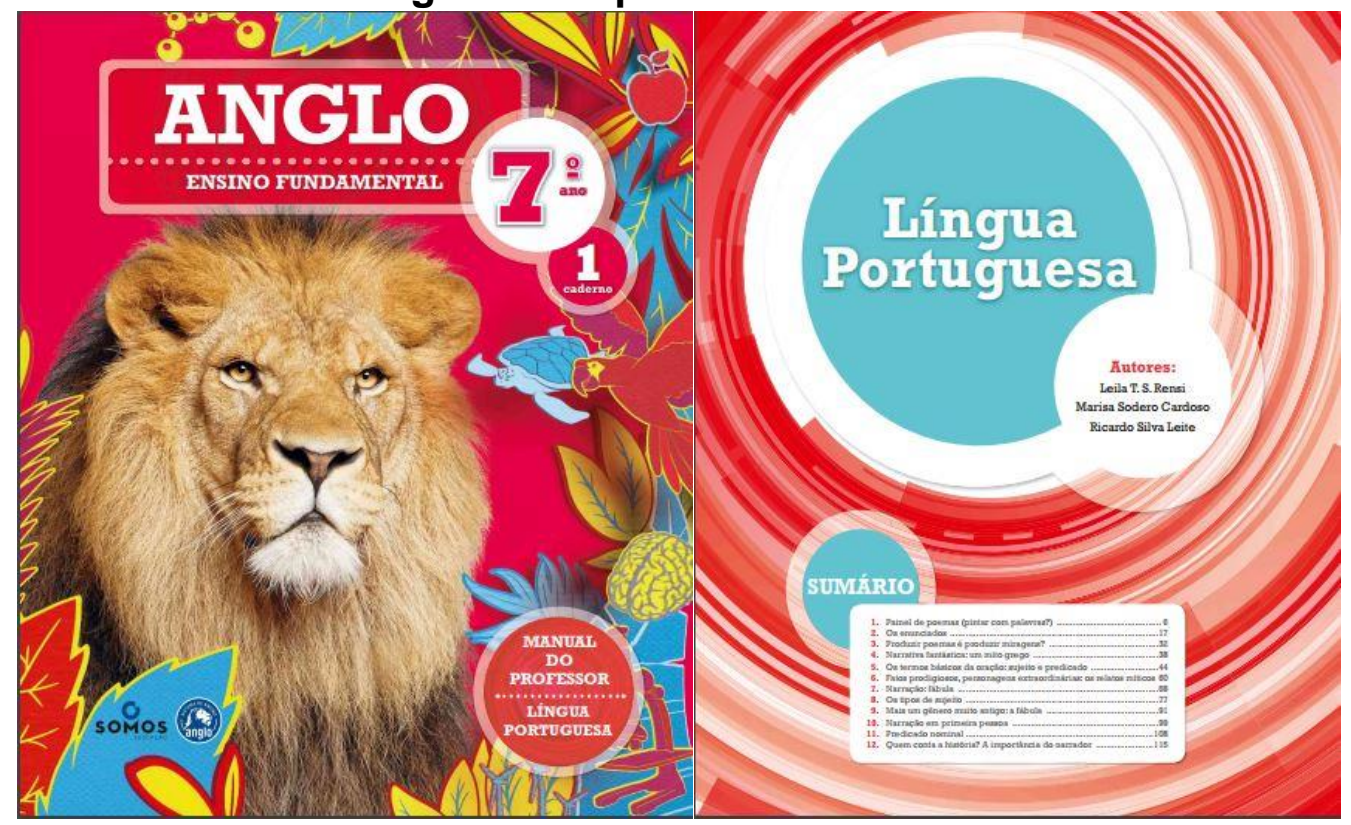

Fonte: Caderno 1 do material do $7^{0}$ ano - Língua Portuguesa.

No capítulo 10: Narração em 1a pessoa, a proposta de leitura se constrói em torno de um fragmento do autor modernista José Lins do Rego. O material de leitura traz um trecho de Menino do Engenho, de José Lins do Rego e é aqui que se encontra a chave para o trabalho com a autobiografia. Não há menção direta entre a identificação do autor e do narrador da obra no caderno do aluno, o capítulo tem Histórias da Velha Totonha, da obra do paraibano que está reproduzido quase que na íntegra no material, como se pode observar abaixo: 


\section{Figura 2: Histórias da velha Totonha}

Você sabia?
20 de março é o Dia Intemacional do Contador de Históras. Fssa comemo-
raçao teve origem na Suécia, na década de 1990 .

\section{LEITURA}

O fragmento de Menino de engenbo reproduzido a seguir descreve uma velha contadora de histórias - a velha Toxonha, ou Toxônia - do estado da Paraiba, no Nordeste.

Faça uma primeira beitura, silenciosa e muito atenta, mas sem internupçao.

Em seguida, releia o texto, agora observando detalhes, avançando lentamente e, quando necessírio, recuando para estabelecer relaçóes com passagens jă lidas, ou interrompendo a leitura para consultar o vocabulário Sublinhe trechos que julgar importantes ou interessantes; anote dúvidas que surjam na compreensåo do texto. Após a leitura, participe da conversa sobre o texto, que será dirigida pelo professor.

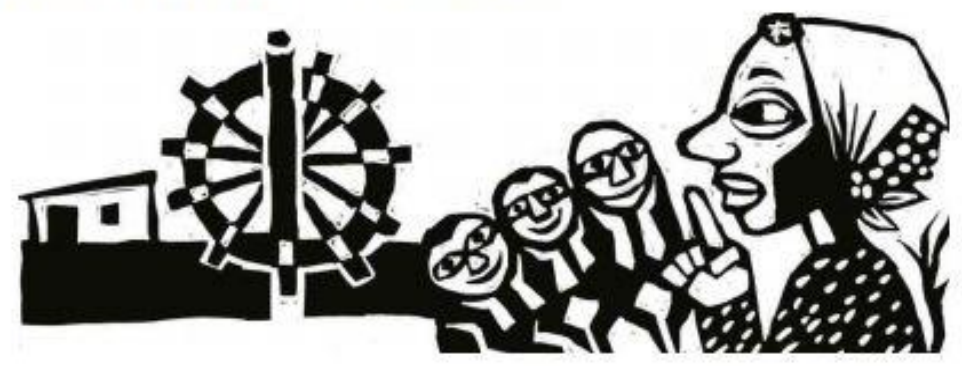

Histórias da velha Totonha

A velha Totonha de quando em vez batia no engenho. E era um acontecimento para a meninada. Ela vivia de contar bistorias de Triticoso. Pequenina e toda léguas a pé, de engenho a engenho, como uma ediçào viva das Mil $e$ uma noites. Que talento ela possuía para contar as suas histórias, com um jeito admirável de falar em nome de todas as personagens. Sem nem um dente na boca, e com uma voz que dava todos os tons às palavras.

As suas histónias para mim valiam tudo. Ela também sabia escolher o seu au. ditório Não gostava de contar para o primo Silvino, porque ele se punha a tagarelar no meio das narrativas. Eu ficava calado, quieto, diante dela. Para este seu ouvinte a velha Totonha nāo conhecia cansaço. Repetia, contava mais uma, entrava por uma perna de pinto e saja por uma perna de pato, sempre com aquele seu sorriso de avó de gravura de livros de história. E as suas lendas eram suas, ninguém sabia contar como ela. Havia uma nota pessoal nas modulaçèes de sua voz e uma expressão de humanidade nos reis e nas rainhas dos seus contos. O seu Pequeno Polegar era diferente. A sua av́ que engordava os meninos para comer era mais cruel que a das histórias que outros contavam.

Histórias is Thanctoo Grecialo Fernandes

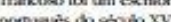
Derante un enono de pesc

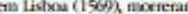
gu milher, does filhose un nex. Para distrair-se of su sectimerno, comesou majiados gerilmeree nus

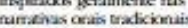
Seu troo Connos e hisainas de prexeifoe ceratupb (157) comolese populas, send muio bla ane o stoub

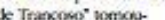
de Trancoso" worick-

popeliar oral, de hissurias lansissicis, ou de histioric du caroctinta. Engelladoc encarquilhado, 


\section{Figura 3: Histórias da velha Totonha - continuação}

A velha Totonha era uma grande artista para dramatizar. Ela subia e descia ao sublime sem forçar as situações, como a coisa mais natural deste mundo. Tinha uma memóna de prad pro. Recitava contos inteiros em versos, intercalando de vez em quando pedaços de prosa, como notas explicativas. Havia a história de um homem condenado à morte. Os sinos já dibrrivani para o desgraçado que caminhava para a forca. Era acusado por crime de morte. Todos os tud os estavam contra ele. E quando o cortejo passava pela porta da casa de sua mulher em lágrimas, um seu filho que mamava tirou a boca do peito, e começou a falar em versos, e descobriu tudo, salvando o pai que ia morrer inocente. Os versos que esse menino recitava, a velha Totonha declamava com uma expressâo de dor de arrepiar. As lágrimas vinham-me aos olhos com aquele lamento fanhoso de menino de peito a cantar.

Havia sempre rei e rainha, nos seus contos, e forca e adivinhações. E muito da vida, com as suas maldades e as suas grandezas, a gente encontrava naqueles heróis e naqueles intrigantes, que eram sempre castigados com mortes horriveis. O que fazia a velha Totonha mais curiosa era a cor loca que ela punha nos seus descritivos. Quando ela queria pintar um reino era como se estivesse falando dum engenho fabuloso. Os nos e as florestas por onde andavam os seus personagens se pareciam muito com o Paraiba e a Mata do Rolo. O seu Bsiba-Azul era um senhor de engenho de Pernambuco.

A história da madrasta que enterrara uma menina era a sua obra-prima. O pai saíra para uma viagem comprida, deixando a filha, que ele amava mais do que tudo, com a sua segunda mulher. Quando partiu, encheu a mulher de recomendaçōes para que tivesse todos os cuidados com a filha. Era uma menina de cabelos louros, linda como uma princesa. A madrasta, porém, não queria bem a ela, com os ciúmes do amor do seu marido pela menina. Pegou entăo a judiar com a bichinha. Era ela quem ia de pote na cabeça buscar água no rio, quem tratava dos porcos, quem varria a casa. Nem tinha mais tempo de brincar com as suas bonecas. Parecia uma criada, com os cabelos maltratados e a roupa suja. Lá um dia a madrasta mandou que ela ficasse debaixo de um pé de figueira, com uma vara na mào espantando os sabiás das frutas. E a menina ficava o dia inteiro tangeed os passarinhos com fome. As rolas lavandeiras, aquelas que lavam as roupas de Nosso Senhor, vinham conversar com ela, contavam-lhe histórias do céu. Mas um dia ela se pós a olhar para o mundo bonito, para o céu azul e a alegria toda do canto dos pássaros. Na sombra da figueira, com aquele mormaço do meio-dia, adormeceu sonhando com o pai que andava longe e com os brinquedos que trania. E os sabiás pinm irim os figos da figueira. Era o que a madrasta queria. Pegou a menina, deu-lhe uma surra de matar, e a enterrou, ainda viva, na beira do rio. De volta o pai chorou como um desgraçado, com a noticia da morte da filha. A madrasta contou que a menina adoecera desde que ele botara os pés fora de casa:

- Nāo houve remédio para a pobrezinha.

Uma manhã, porém, o capinero do engenho saiu para cortar capim para os cavalos. Uma couceira bem verde crescia do meio do capinzal. Ele meteu a serra. Ouviu então de dentro da terra uma voz muito de longe. Pensou que fosse engano de suas ouças, e meteu outra vez a serra. Af uma voz doida, como a de uma alma sofrendo, levantou-se numa cantiga:

Capineiro de meu pai,

nä̀ me corte os meus cabelos.

Minha mäe me penteou,

minha madrasta me enterrou,

pelos figos da figueira

que o passarinho picou.

O capineiro assombrado correu para chamar o senhor de engenho. E voltaram com a enxada, e cavaram a terra. A menina estava verde como uma folha de mato.

Fonte: Caderno 1 do material do $7^{\circ}$ ano - Língua Portuguesa. 
Figura 4: Biografia de José Lins do Rego

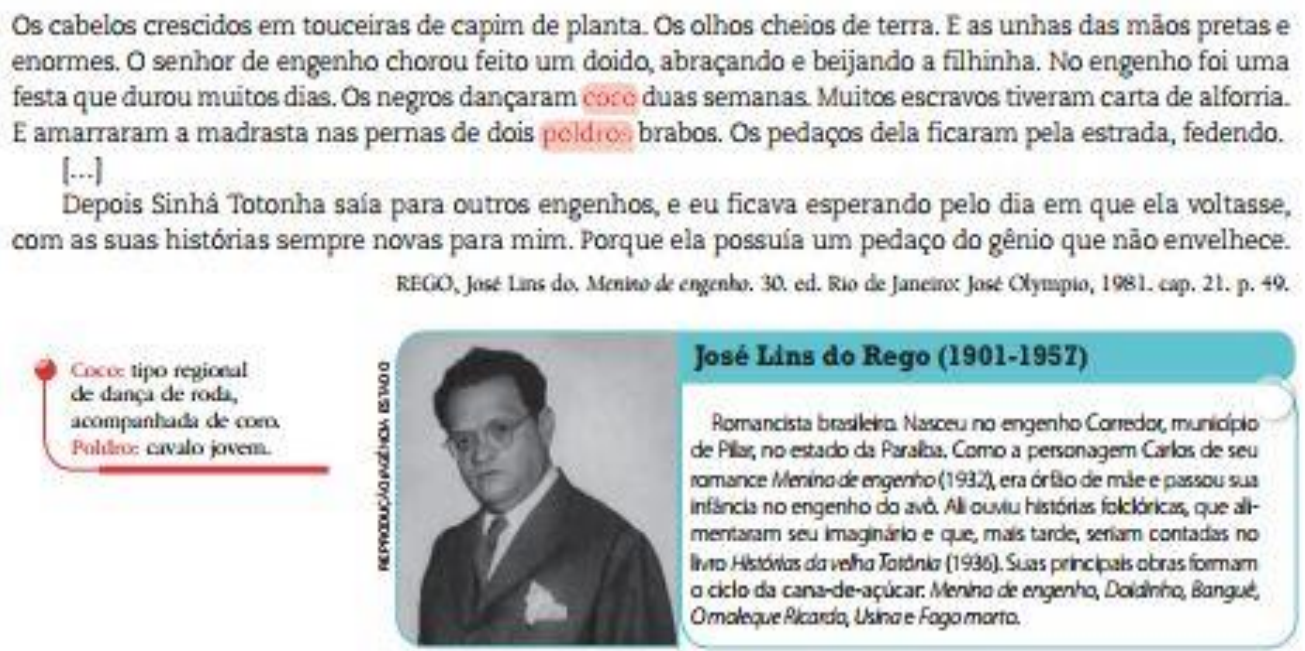

Fonte: Caderno 1 do material do $7^{\circ}$ ano - Língua Portuguesa.

A pequena biografia no quadro após o texto insinua uma aproximação entre o autor e a personagem Carlos no seguinte trecho: "Como a personagem Carlos de seu romance Menino de Engenho (1932), era órfão [José Lins do rego] de mãe e passou sua infância no engenho da avó." No Manual do Professor, há uma sugestão para que se comente a relação entre a história de vida de José Lins do Rego e Carlinhos, classificando o romance como autobiográfico.

A atividade proposta, que será descrita no próximo capítulo, leva em consideração a sugestão do material de leitura e aprofunda o trabalho com a autobiografia nas aulas de produção de texto. 


\subsection{Atividades de escrita autobiográfica no $7^{\circ}$ ano: da leitura à produção}

\section{Quadro 1: A escrita sobre o eu}

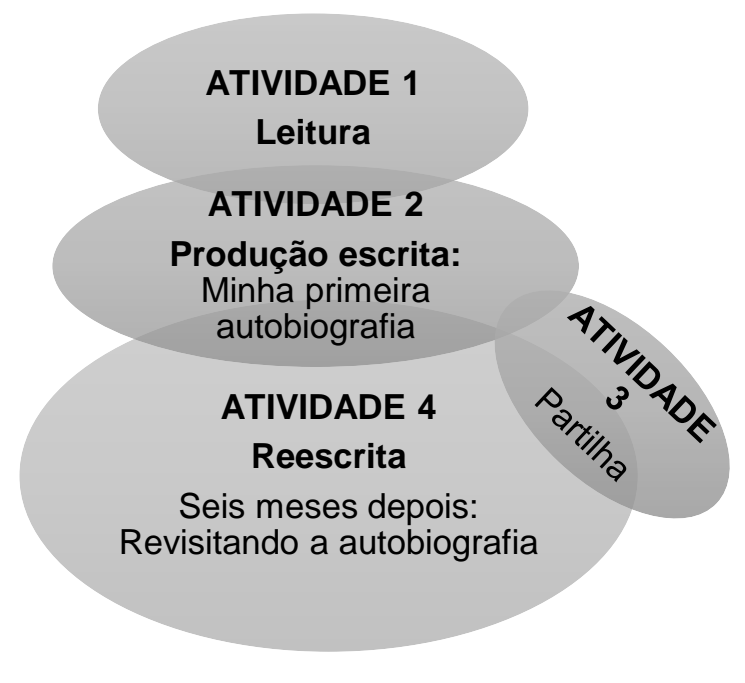

Fonte: Elaboração feita pela autora.

A organização das atividades em círculos materializa a não linearidade das atividades, ou seja, elas se interconectam em uma instância concreta de ação que é vivenciada de maneira a levar os conteúdos para a etapa seguinte. É clareza de que o texto se constrói e se reconstrói na leitura, e a discussão permite ao estudante ser autor de suas memórias.

A partir da leitura, da compreensão e da reflexão sobre os textos oferecidos, os alunos localizam as características do gênero e assim, sem uma teorização artificial fixam o conteúdo e são capazes de desenvolver os próprios textos. Ao assumir que o leitor contribui ativamente para a construção dos significados, deve-se permitir aos alunos várias interpretações. Naturalmente, o grau de envolvimento do leitor na construção do sentido depende bastante da espécie de texto que é lido. Sendo assim, não se deve negar ao aluno o direito de construir a interpretação dos textos, impondo uma única leitura.

A produção de sentido durante as atividades de leitura depende, em grande parte, do material escolhido para isso, já que os textos são variados e atendem aos 
interesses dos alunos, sendo mais fácil de garantir um maior envolvimento destes com a leitura. Por isso, dedicou-se tempo na seleção dos textos literários das atividades.

Os critérios de seleção das obras foram apresentados no item 2.2 que tratou do percurso de escolha dos títulos autobiográficos, inicialmente dez obras, para que alcançássemos uma atividade enxuta mas densa, escolhemos trabalhar com excertos quatro obras selecionadas, obedecendo quatro fatores, que julgamos relevantes para a fase dos alunos em questão: sexualidade na adolescência; estilo coloquial; narrativa de suspense e referência.

\section{(A) Sexualidade na adolescência}

Depois daquela viagem (1997) de Valéria Piassa Polizzi, aborda o tema da sexualidade na adolescência, o que é também uma questão presente no cotidiano dos alunos. Essa obra autoriza a discussão do assunto em aula. Em linguagem coloquial, quase como um diário, Valéria, uma menina paulistana nascida na década de oitenta, trata de um assunto sério, a sua contaminação aos 16 anos pelo vírus da AIDS; fala do medo e da insegurança com os exames e o tratamento, além da relação com a família e com os amigos, os quais, durante pelo menos dois anos, não souberam da condição de Valéria. Dois trechos foram selecionados para a leitura compartilhada, o primeiro sobre o contato inicial com o "cara" com quem teve a relação desprotegida e foi contaminada e, o segundo, sobre o momento da descoberta da doença.

No Natal de 1986 eu tinha quinze anos e estava fazendo uma viagem de navio para a Argentina com meu pai e minha irmã, que é três anos mais nova do que eu. O navio era lindíssimo, cheio de salas, bares, restaurantes, cassino, piscina e show todas as noites. $O$ ambiente era estritamente familiar, muitas vovós, crianças, pais e mães, todo mundo passando o Natal junto, na maior calmaria. Piscina pela manhã, um jantar de gala à noite $e$, durante a tarde, uma volta pelas dependências do navio. E foi numa dessas, um belo dia, que eu vi um cara tropeçando. No auge dos meus quinze aninhos, não pude resistir e dei uma risadinha.

POLIZZI, Valéria Piassa. Depois daquela viagem. São Paulo: Ática, 1997, p.9.

\section{\#}

Pronto. Não precisava dizer mais nada. Eu estava com AIDS. Aquele médico deve ter feito um teste sem meu consentimento e pior, deve ter ligado para o meu pai para dar o resultado. Que sacanagem, ele não tinha esse direito! Não consegui dizer uma palavra e também não me atrevi a olhar para o meu pai. Ficamos os dois em silêncio, olhando pela janela do carro. Eu pensando no susto que ele devia ter levado, ele pensando sabe Deus o quê. 
POLIZZI, Valéria Piassa. Depois daquela viagem. São Paulo: Ática, 1997, p.27.

\section{(B) Estilo coloquial}

Rinaldo Santos Teixeira em Léo, o pardo (2006) fala da cor de sua pele, a cor parda, como o título sugere. Seus pais tinham baixa escolaridade. Numa cidade pouco conhecida, Santana do Jacaré, no interior de Minas Gerais, Léo vive os primeiros anos da sua infância, suas primeiras brincadeiras e começa a descobrir o mundo.

Dois trechos foram escolhidos, um que trata do seu trabalho sob uma perspectiva bem-humorada e uma passagem sobre a descrença da mãe em relação às suas vontades e sonhos.

Trata-se de uma linguagem mais informal e cotidiana, com expressões coloquiais e uma sintaxe simples, o autor prende a atenção do leitor que tem uma leitura fluida do texto. Tal tipo de texto é interessante para que os alunos se sintam mais próximos da norma culta, em um tom mais leve e espontâneo, uma vez que foi proposto aqui um exercício de produção textual, o manejo da língua materna deve ser mais espontâneo e livre, por isso apresentar um bom texto que é acessível, que constrói uma autobiografia de forma mais coloquial é essencial.

Dia desses, lembrei dos sonhos que tinha quando trabalhava com meu irmão, o Claudinei, na granja São Francisco, em Campo Belo, Minas Gerais. O dia todo cortando frangos: coxas, sobrecoxas, cabeças e pés de frango, e entrando naquela geladeira não sei quantos graus abaixo de zero, depois de comer uns pães de queijo, murchinhos, oferecidos pela Dona Celeste. De noite, eu deitava e sabia que estava pegando no sono quando os frangos, pelados, vinham dançar na minha cabeça, batendo as asinhas, rebolando.

TEIXEIRA, Rinaldo Santos. Léo, o pardo. Brasília: Literatura para todos, 2006, p.13.

\#

Então, tivemos alegrias e tristezas, mas aos dezesseis anos eu cheguei pra minha mãe e disse que queria muito morrer. E ela me olhou de modo seco. Minha mãe é realmente estranha, por exemplo, ela nunca chora, eu nunca vi a Dona Preta chorar. A tristeza dela se transforma em manchas roxas pelo corpo. Pra gente ela sempre aconselhava, "não chora tanto, menino, que lágrima é uma coisa que seca, quando a alma mais precisar dela, aí não desce mais". E nesse dia, eu tinha dezesseis anos e ela me disse: "se a vida não tem e nem te dá um propósito, então inventa, escolhe uma coisa que você gosta e briga por ela. Você gosta de livros por que então não vai ser professor?" Mas daí eu disse: "cinema", e ela respondeu: "que que tem o cinema?" E eu falei de novo, "eu vou fazer cinema". Ela ajeitou a fita métrica no pescoço, riscou o tecido de acordo com o molde que vinha fazendo e com firmeza passou a tesoura. "De filho de preto que eu já tive notícia que fez cinema foi só minha prima, que quando mudou pra 
São Paulo foi figurante do filme Ticotico no Fubá". E eu repeti: "cinema, vou fazer cinema". E por causa disso eu fiquei vivo. Se eu consegui, depois vocês vão ficar sabendo.

TEIXEIRA, Rinaldo Santos. Léo, o pardo. Brasília: Literatura para todos, 2006, p.24.

\section{(C) Narrativa de suspense}

O tema do suspense é unânime com os alunos dessa faixa etária, entre $11 \mathrm{e}$ 14 anos. Na elaboração da atividade, foram selecionados textos e levado em conta gostos específicos dos alunos, como já haviam ocorrido com a história do Jack, o estripador; trazê-lo novamente para a discussão do texto autobiográfico seduz de uma maneira positiva, pois de maneira direta "escutam" a voz desse personagem da história que tanto demonstraram interesse. Em Eu sou Jack, o estripador: a autobiografia do mais famoso assassino da história (2016), de James Carnac, o assassino aborda a sua infância até a sua morte, e contém informações que nunca foram divulgadas.

O primeiro fragmento escolhido fala sobre a infância e a escola, gerando uma proximidade entre alunos e personagem. $O$ segundo excerto fala sobre o sadismo do assassino que gostava de cortar carne humana.

Posso tocar apenas de passagem esses anos primordiais, pois a memória deles é intermitente, e os incidentes triviais que sou capaz de lembrar pouco me interessam. Vou pular o período dos meus primeiros anos escolares no que deve ter sido, creio eu, uma escola da igreja ou na casa de uma professora, e tentar descrever minha primeira escola de garoto para a qual fui enviado com aproximadamente doze anos.

CARNAC, James. Eu sou Jack, o estripador: a autobiografia do mais famoso assassino da história, tradução de Jorge Ritter. São Paulo: Seoman, 2016, p.33.

\#

Acho que foi o fascínio em relação a facas que consolidou minha decisão de adotar a profissão do meu pai. Eu não tinha desejo algum de tratar caxumba ou sarampos, tampouco, admitirei, qualquer desejo de aliviar o sofrimento humano. Mas eu queria dissecar. Eu queria cortar carne, não a carne cozida, mas a carne humana. Quão demoníaco isso deve parecer[...].

CARNAC, James. Eu sou Jack, o estripador: a autobiografia do mais famoso assassino da história, tradução de Jorge Ritter. São Paulo: Seoman, 2016, p.93.

\section{(D) Referência}

José Lins do Rego em Meus Verdes Anos elabora com primor a narrativa autobiográfica de Carlos, e torna-se referência, pela excelente composição. Um autor 
regionalista, deixa marcas fortes da sua terra de origem no texto, paraibano de Engenho Corredor, nascido em 1901, retrata com detalhes as relações familiares e o desabrochar da sexualidade, por exemplo. Nos três trechos selecionados, escolhe enfatizar a sua contraditória relação com a avó, por quem não nutria amor e as experiências conturbadas com a tia e com os meninos da região.

[...] é preciso confessar: não gostava de minha avó. Aversão gratuita, pois ela nunca levantou a mão contra mim. E me sentia mal a seu lado. Era uma figura sombria, guardava preferências absurdas, não era amada pelas negras da cozinha. O vício do rapé dava-lhe uma cor esquisita ao nariz. E como não enxergava bem, ficava sentada o dia todo numa cadeira de balanço a dormitar [...].

REGO, José Lins. Meus Verdes Anos. Rio de Janeiro: José Olympio, [1956] 9 ed., 2011, p.22.

\#

[...] Sempre de manhã a minha tia me acordava para tomar leite ao pé da vaca. Nas manhãs de sol o curral dos animais de manjedoura se enchia de trabalho. Os moleques curavam as bicheiras, lavavam os bezerros novos e o mestre Amâncio tirava leite. Se chovia, tudo se transformava em lama que atolava até as canelas. Vinham meninos das redondezas atrás do leite que o meu avô dava aos pobres. Esguichava na cuia branca o leite das turinas. Ainda não havia aparecido as febres no gado. Tudo era são. Vacas que davam cuias e cuias de leite. Conhecíamos todas pelos nomes: Mocinha, Malhada, Estrela Nova, Cotovia [...].

REGO, José Lins. Meus Verdes Anos. Rio de Janeiro: José Olympio, [1956] 9 ed., 2011, p.33.

\#

[...] Uma vez mandaram dizer a tia Naninha que eu ficava para jantar. $E$ ela não permitiu. E foi áspera quando eu cheguei. Só imaginar a cara do marido chegando na mesa com as suas histórias fazia-me infeliz. Caí no pranto com a reprimenda da tia. E ela, que nunca me batia a sério, veio furiosa em cima de mim, de chinela, como se eu fosse Virgínia. Deixou-me o corpo marcado [...].

REGO, José Lins. Meus Verdes Anos. Rio de Janeiro: José Olympio, [1956] 9 ed., 2011, p.130.

O processo de leitura teve como um percurso de desenvolvimentos; o primeiro passo foi a tomada de consciência de que se trata de um processo interno e precisa ser ensinado/aprendido. Os alunos precisam assistir a um processo de leitura que lhes possibilite ver estratégias de compreensão do texto em ação em uma situação significativa e funcional.

Realizou-se comentários de antecipação do tema a partir de elementos paratextuais, como título, subtítulo, do exame de imagens, entre outros, e por isso, as 
capas dos livros e as referências bibliográficas foram os primeiros elementos trabalhados para cada autor. Além disso, já faz parte da atividade de leitura, o levantamento do conhecimento prévio sobre o assunto como pontuado acima.

Durante a atividade, foram proferidos comentários que ajudassem a localizar a ideia central, além da formulação de hipóteses a respeito da sequência do enredo. Por fim, o trabalho após a leitura segue em direção à construção da síntese semântica do texto, além da troca de impressões a respeito do que foi lido, tanto em relação ao conteúdo quanto à forma.

A finalização da atividade direcionou o olhar dos alunos para as marcações pronominais e temporais, características do tipo textual trabalhado e sistematizou as principais características do gênero.

\subsection{Etapas da produção escrita em aula}

Planejou-se que, durante a leitura, as obras e os seus autores fossem apresentados, ainda que de forma rápida, tentando contextualizar o enredo dos quais os trechos selecionados foram retirados. Trazer a vida dos autores e do enredo, bem como questões sobre a circulação das obras oferece materialidade à situação comunicativa que estão investigando. Definiram-se duas fases de leitura: a coletiva e a silenciosa, para que, posteriormente, acontecesse a discussão. O objetivo da atividade de leitura foi fazê-los sentir que a necessidade do relato constitui nossa natureza, bem como a curiosidade sobre a vida do outro. É na apreciação da variedade de textos que se torna possível a identificação. O texto, de maneira silenciosa, vai liberar algo que o leitor tem dentro de si. E o leitor, muitas vezes, encontra ali energia para sair do contexto em que estava preso, para se diferenciar, para se libertar dos estereótipos.

A discussão levou em conta questões estruturais do gênero e, principalmente, sobre o conteúdo. Após a finalização da Atividade 1, de leitura, programou-se a Atividade 2, de produção escrita, em que os alunos receberam uma folha para produzirem as próprias autobiografias. A orientação definida era para que elaborassem um rascunho antes de utilizarem o espaço destinado à versão final.

A Atividade 3, a ser realizada após seis meses, consistia na reelaboração das narrativas. A refação dos textos autobiográficos torna possível o mapeamento das 
mudanças corridas no semestre, em relação ao amadurecimento desses jovens em diferentes aspectos, tanto textuais quanto vivenciais.

\subsection{Organização e desenvolvimento das atividades didáticas}

Os alunos responderam a um questionário para compreensão do lugar social dos estudantes. As respostas obtidas estão dispostas a seguir:

\section{Tabela 1: Idade}

\begin{tabular}{|c|c|}
\hline Idade & №. de alunos \\
\hline 11 & 24 \\
\hline 12 & 25 \\
\hline 13 & 4 \\
\hline
\end{tabular}

Fonte: Elaboração feita pela autora.

Tabela 2: Nacionalidade

\begin{tabular}{|c|c|}
\hline Nacionalidade & №. de alunos \\
\hline brasileira & 51 \\
\hline italiana & 1 \\
\hline peruana & 1 \\
\hline
\end{tabular}

Fonte: Elaboração feita pela autora.

Tabela 3: Escolaridade dos pais

\begin{tabular}{|c|c|c|}
\hline Escolaridade & Pai & Mãe \\
\hline ensino médio & 6 & 5 \\
\hline ensino superior & 41 & 36 \\
\hline outro & 6 & 12 \\
\hline
\end{tabular}

Fonte: Elaboração feita pela autora.

Nas etapas de leitura (Atividade 1) e da produção escrita (Atividade 2), utilizaram-se 4 aulas de 50 minutos cada. As atividades aconteceram em 2 dias, em aulas duplas com 5 minutos de intervalo. A aplicação aconteceu entre os dias 6 e 9 de fevereiro de 2017.

$\mathrm{Na}$ apresentação da proposta da pesquisa, os alunos demonstraram empolgação como o gênero e com o fato da produção fazer parte de um estudo, 
ficaram curiosos em relação a como isso seria encaminhado. Após 20 minutos de conversa, iniciou-se o preenchimento do questionário, que foi apresentado como forma científica de coletar dados. Em cerca de 18 minutos, todos os questionários estavam preenchidos. Nos últimos 10 minutos da primeira aula, começou-se a Atividade 1 de leitura com a contextualização das obras e a observação das capas, fazendo a leitura dos elementos não verbais, observando as cores e as imagens.

A leitura coletiva da questão inicial da atividade: Você gosta de ouvir histórias de vida? Quando você escuta essas histórias? despertou interesse e muitos quiseram comentar, foram 20 minutos nessa discussão, sobre o quanto era divertido escutar história, principalmente histórias que aconteceram "de verdade", como os próprios alunos mencionaram. Relataram que os pais e os avós, falam sobre os momentos do tempo em que tinham a idade deles. Muitos mencionaram o momento que estão dentro do carro como um momento de compartilhar histórias de vida. Iniciou-se assim a leitura dos trechos e, posteriormente, a leitura dos excertos das duas primeiras obras até o sinal sonoro entre aulas.

$\mathrm{Na}$ aula seguinte, retomou-se a leitura dos trechos do quarto autor. Após a leitura, fez-se uma breve explanação gramatical e discutiram-se sobre as impressões dos alunos, tanto em relação à linguagem, quanto em relação à estrutura textual. $A$ seguir, houve a distribuição da Atividade 2, de produção escrita, e as instruções iniciais, o que gerou uma breve discussão sobre o número de linhas e como selecionar os fatos narrados.

Grande parte dos alunos demonstrou angústia justamente com o número reduzido de linhas, uma vez que deveriam contar a história de uma vida inteira, contudo, a orientação foi a de que eles buscassem o que tivessem de mais constitutivo e marcante em suas vidas, levando em conta lugares e pessoas, para que tivessem um critério de escolha e um direcionamento na reflexão. Na quarta aula da sequência, iniciou-se a produção, o silêncio durou cerca de 35 minutos. Todos demonstraram envolvimento com a atividade. Grande parte não conseguiu produzir a versão final em sala, levando para a casa como tarefa. A seguir, fotos das turmas tiradas pela autora, no momento da produção escrita. 
Figura 5: Registro do $7^{\circ}$ ano no momento da Atividade 2 - Produção escrita

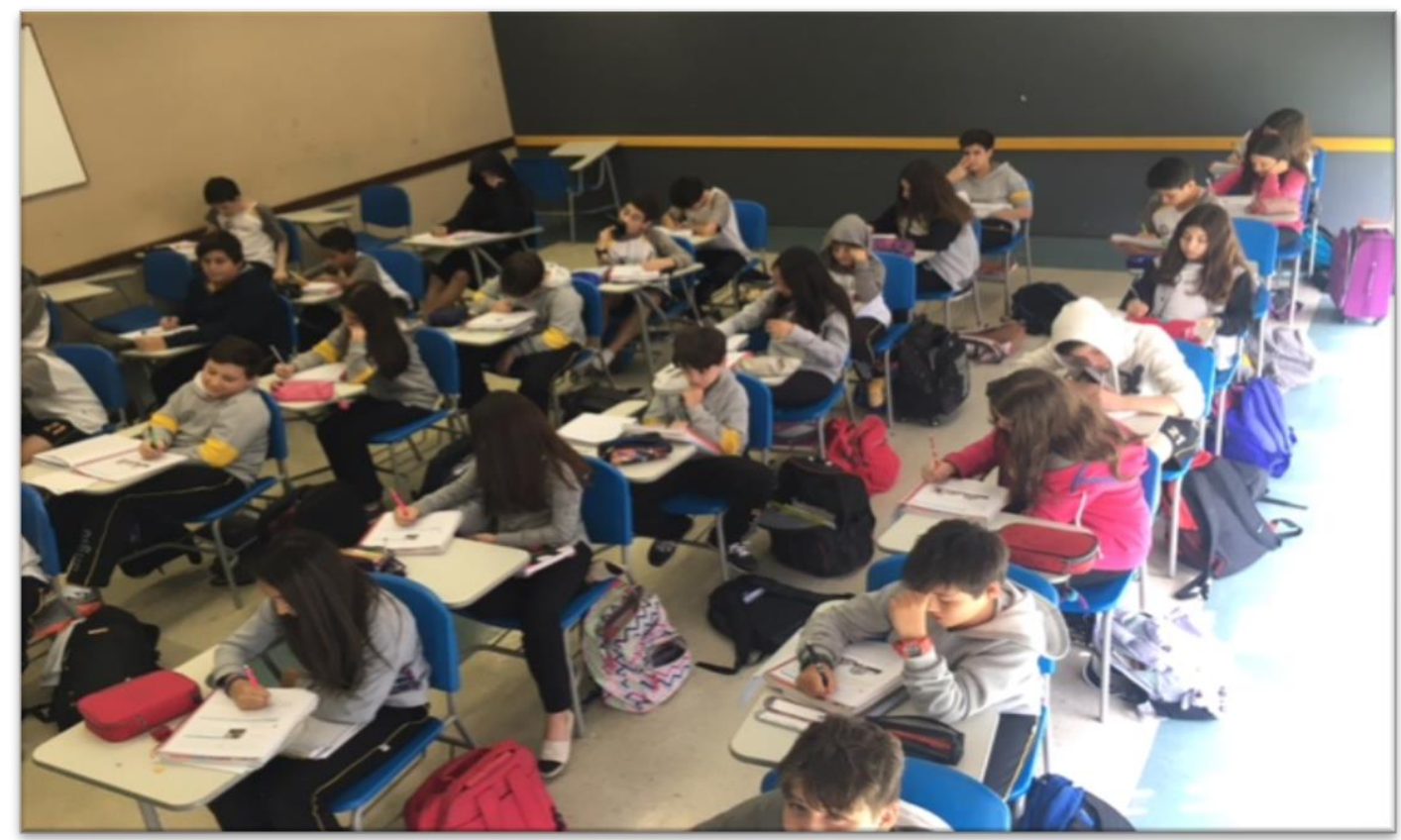

Fonte: Elaboração feita pela autora.

Figura 6: Registro do 7ํ B no momento da Atividade 2 - Produção escrita

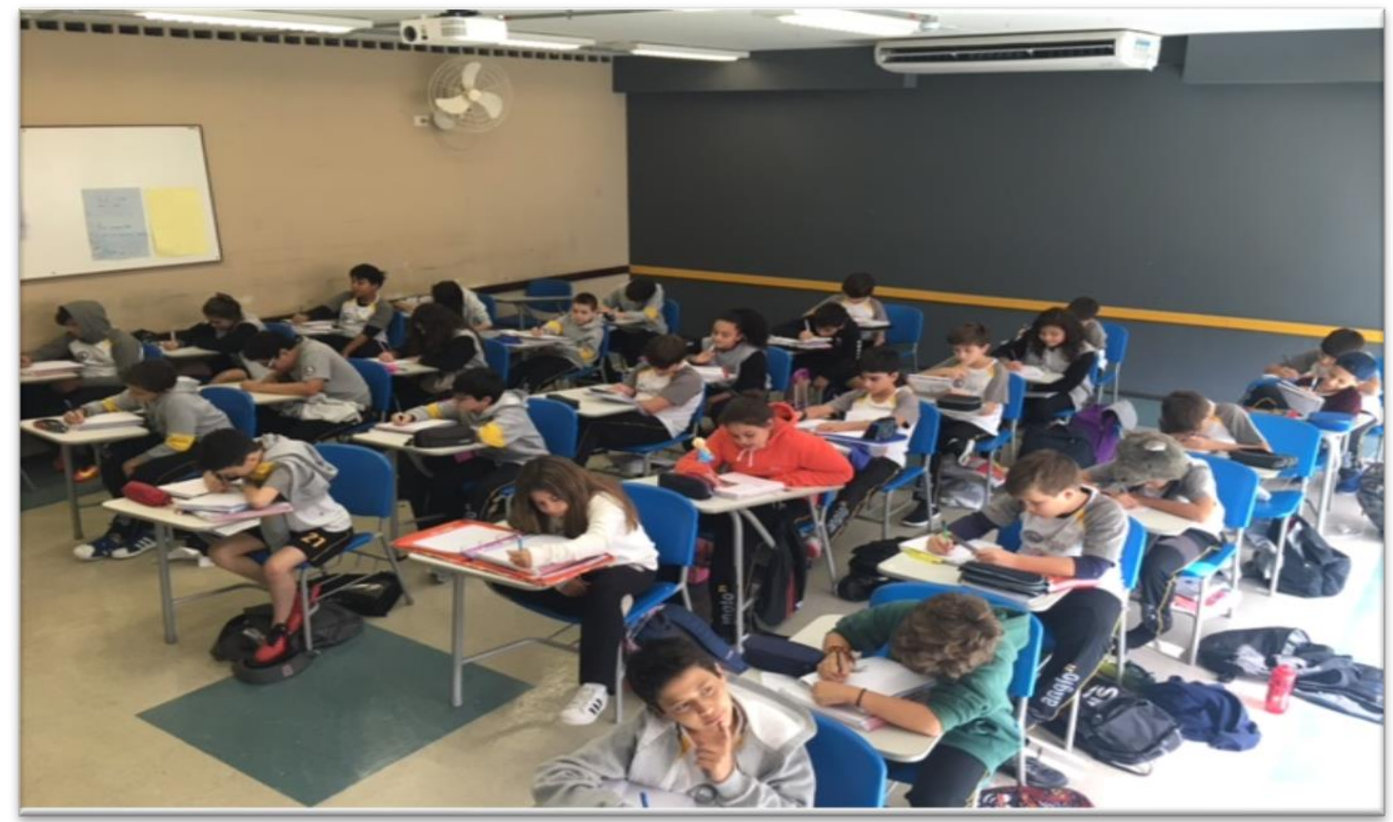

Fonte: Elaboração feita pela autora. 
Para o fechamento das atividades, julgou-se necessário que houvesse um momento de conversa sobre a experiência com o gênero autobiográfico, principalmente sobre o processo de produção na aula seguinte, quando muitos entregaram as versões finais da primeira versão de seus textos. Nas duas turmas tivemos depoimentos que demonstraram o envolvimento dos alunos com a questão autobiográfica:

T: "senti a emoção de ser EU mesmo";

F: "coloquei minha vó... porque assim as pessoas vão saber dela, né:.:, ela fica viva assim";

D: "eu chorei um pouco";

G: "não gostei, senti vergonha de quem vai ler";

L: "Eu também não gosto muito da minha vó, igual o José, falei disso na minha história".

A Atividade 3 de reescrita, que aconteceu nos dias 25 e 26 de setembro de 2017, em ambas as turmas, iniciou-se a partir da retomada de conceitos; o trabalho foi idealizado em duplas, para que em pares semelhantes buscassem melhorias no texto. Para que houvesse certo direcionamento, os alunos tiveram duas perguntas como guia, uma em relação ao conteúdo temático e outra em relação à estrutura textual: (a) Quais aspectos mais chamaram a sua atenção na história de vida do seu parceiro? Por quê? O que mais você gostaria de saber? (b) Quais aspectos narrativos chamaram mais a sua atenção? O texto apresenta uma estrutura clara? Justifique suas respostas. Então, após cerca de 20 minutos de diálogo, os alunos partiram para a reescrita com as sugestões dos colegas.

A conversa inicial retomou as leituras em um momento espontâneo, e os alunos lembraram com mais detalhes da autobiografia de James Carnac, o Jack estripador. Comentaram-se características do gênero a partir do enunciado da atividade reproduzida a seguir: 


\section{Figura 7: Atividade de reescrita}

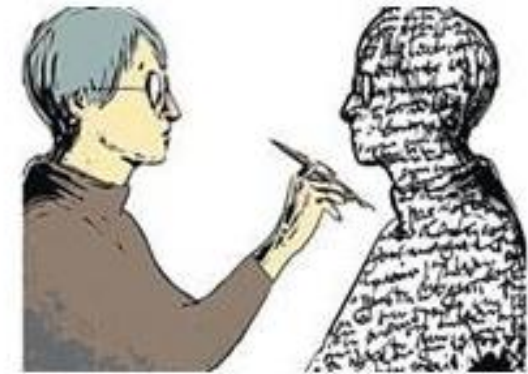

Esta atividade está organizada em duas etapas:

\author{
Você ge recorda da atividade que \\ fizemos sobre autobiografias no primeiro \\ semestre? As leituras e a sua produção? \\ A autobiografía é um texto escrito pelo \\ próprio autor, que não precisa seguir uma \\ estrutura e a sua finalidade é contar a sua \\ própria vida tendo como interlocutor o público \\ em geral Geralmente, na autobiografia, o autor \\ traz dados pessoais, ou seja, verídicos e os \\ verbos são empregados no passado.
}

Etapa 1

Reina-se com seu colega para que cada um possa se tornar leitor critico do texto do outro. Nesga releitura, observe se o autor considerou a presença de um interlocutor e realizou a seleção de dados importantes da vida pessoal. O que mais vocé gostaria de saber sobre a trajetória de seu amigo? Ajude-o a construir a melhor autobiografia possivel.

Etapa 3

Em seguida, façam as alterações que julgarem necessárias reescrevendo os próprios textos e passem a limpo.

Fonte: Elaboração feita pela autora.

A Atividade 3 consistiu na troca dos textos para possibilitar um olhar crítico necessário para a refação, os alunos passaram por muitas transformações na fase inicial da puberdade e isso, possivelmente, refle em questões estilísticas e na seleção dos fatos. É interessante como eles mesmos se surpreendem com suas palavras. Não houve muitas interferências para que os alunos pudessem de fato ter a liberdade para opinarem sobre os textos alheios e alterarem os próprios sem ruído. Optamos por não realizar a correção dos textos, tornando os próprios alunos revisores dos textos dos colegas.

Os alunos foram organizados em duplas e receberam os respectivos textos, e incentivados a fazer leituras silenciosas e escreverem as sugestões para os colegas. Dos 55 alunos que produziram as autobiografias e participaram das Atividades 1 e 2, 42 participaram da reescrita.

Abaixo segue o quadro de identificação dos textos. Como referência às produções textuais, enumerou-se cada um dos textos de maneira aleatória, não 
havendo distinção em relação a nenhum fator específico; a priori, optou-se assim para uma leitura isenta de valoração em relação à ordenação.

A partir das 42 produções escritas, constituiu-se três núcleos temáticos, os quais serão explicitados a seguir no Capítulo 4, na abordagem da análise.

\section{Quadro 2: Identificação das produções escritas}

\begin{tabular}{|c|c|}
\hline Identificação & \\
\hline $\begin{array}{c}\text { Produção } \\
\text { escrita }\end{array}$ & Título da produção escrita \\
\hline PE1 & Sem título \\
\hline PE2 & Minha auto-biografia \\
\hline PE3 & A batida \\
\hline PE4 & Sem título \\
\hline PE5 & Sem título \\
\hline PE6 & Sem título \\
\hline PE7 & Biografia \\
\hline PE8 & As loucuras das mudanças \\
\hline PE9 & Sem título \\
\hline PE10 & Sem título \\
\hline PE11 & Sem título \\
\hline PE12 & Sem título \\
\hline PE13 & Sem título \\
\hline PE14 & Uma vida de loucuras \\
\hline PE15 & Sem título \\
\hline PE16 & Minha autobiografia \\
\hline PE17 & A primeira vez que eu surfei \\
\hline PE18 & Sem título \\
\hline PE19 & Sem título \\
\hline PE20 & Sem título \\
\hline PE21 & Sem título \\
\hline PE22 & Sem título \\
\hline PE23 & Minha 1a mudança \\
\hline PE24 & Sem título \\
\hline PE25 & Minha vida \\
\hline PE26 & Sem título \\
\hline PE27 & Minha vida como viajante \\
\hline PE28 & Minhas férias \\
\hline PE29 & 5 coisas da minha vida \\
\hline PE30 & Sem título \\
\hline PE31 & Sem título \\
\hline PE32 & O Pior Intercâmbrio \\
\hline PE33 & Sem título \\
\hline PE34 & Sem título \\
\hline PE35 & Sem título \\
\hline PE36 & Desventuras em série \\
\hline PE37 & Sem título \\
\hline PE38 & Minha auto biografia \\
\hline PE39 & Sem título \\
\hline PE40 & Sem título \\
\hline PE41 & Enzo Murbach Belmonte da Silveira \\
\hline PE42 & Sem título \\
\hline
\end{tabular}

Fonte: Elaboração feita pela autora 


\section{Capítulo 4}

\section{NARRATIVAS AUTOBIOGRÁFICAS DE ALUNOS DE 7ํㅗㅇ ANO: TEMPO DE MUDANÇAS}

A análise de narrativas autobiográficas produzidas pelos estudantes do $7^{\circ}$ ano organizou-se em torno de núcleos temáticos a partir das 42 produções escritas. Para encontrar uma unidade, ou seja, a intimidade das memórias dos jovens alunos, partiuse de uma análise quantitativa e, posteriormente, buscou-se abranger qualitativamente valores presentes nos textos. Optamos por usar apenas as iniciais para que a identidade dos alunos fosse preservada. $\mathrm{Na}$ atividade autobiográfica, os estudantes se tornam narradores de suas próprias histórias. Nas aulas, as questões pessoais aparecem de modo superficial nas relações do cotidiano, não é recorrente o trabalho sobre suas trajetórias de vida e familiar. $O$ assunto não é diretamente abordado nos apostilados que eles têm acesso. O estudante é o porta-voz do autorindivíduo-escritor (Charaudeau, 2016, p. 195).

O capítulo está organizado em três seções: nas duas primeiras, busca-se responder ao questionamento: De que maneira linguístico-discursiva os estudantes reconstroem o tempo e o espaço? Na última seção, volta-se à pergunta: Quais elementos memorialísticos emergem das narrativas autobiográficas?

Foram construídos três núcleos temáticos a partir das 42 produções reescritas dos alunos: 


\section{(a) perdas e infortúnios}

Trata, principalmente, da morte de entes queridos e familiares doentes, além de processos de transformação problemáticos, acidentes e acontecimentos ruins;

\section{(b) viagens e deslocamentos}

Reúne trechos narrativos sobre lugares visitados e viagens longas, com frequência mencionam as mudanças de escola e de moradia, o que representa grandes deslocamentos na vida dos estudantes;

\section{(c) conquistas pessoais e alegrias}

Traz narrativas de momentos felizes, vivências das quais os alunos sentem orgulho.

O corpus é composto por textos de diferentes conteúdos, apesar de serem todos compatíveis com o gênero autobiográfico, em relação à estrutura narrativa temos diferentes níveis, alguns apresentam mais elementos narrativos do que outros, mas todos têm em si a essência narrativa, como demonstrado a seguir.

Quanto aos aspectos linguístico-discursivos em relação às marcas de tempo e de espaço, os alunos se situam no aqui e no agora de suas narrativas. Decidiu-se não incluir pessoa como um item do capítulo de análise, uma vez que há pouca produtividade, já que por se tratar da autobiografia tem-se a prerrogativa do texto em 1 a pessoa do singular, ao que 41 alunos obedeceram de forma categórica.

Na produção escrita, que tem como título o nome do autor, E. M. B. S. (PE 41), este constrói a narrativa em terceira pessoa.

Por volta de 2000. Um homem chamado M. A. S,, também conhecido como o melhor pai do mundo diziam seus dois filhos, ele se casou com a mulher mais linda do mundo, ela chamava M. M. B., ela era mãe dos dois filhos do M.. O primeiro filho se chamava E., ele era um garoto super lindo, inteligente, ciclista, e dirigia todo final de semana a saveiro (transmissão manual) de seu avô que morava em Rio Claro (SP). Os anos foram passando e passando e cada dia E. crescia mais, muitos duvidavam até que davam fermento para ele. Em 2011 o 
irmão dele nasceu em São Paulo (SP), e como todo final de história eles viveram felizes para sempre.

Ao analisar o texto, nota-se o tom elogioso para descrever a personagem em terceira pessoa, o que cria um efeito de humor, como no trecho "o primeiro filho se chamava E., ele era um garoto super lindo, inteligente, ciclista, e dirigia todo final de semana a saveiro (transmissão manual) de seu avô". Há conexão direta entre o narrador e a personagem. E. fala de si em terceira pessoa, assim, protege-se do autoelogio, o que possivelmente não foi realizado de maneira consciente, mas ainda assim, demonstra astúcia e certa consciência linguística. $O$ aluno emprega adjetivos como "lindo", "inteligente" para atribuir qualidades a ele mesmo, um autoelogio. Ele deixa de mencionar as qualidades do irmão, simplesmente citando o seu nascimento.

A ressalva em relação a categoria de pessoa é essencial para que a linguagem se torne discurso. Passa-se assim, a análise das categorias de tempo e espaço. Segundo Fiorin (2016, p.36), "o aqui é o espaço do eu e o presente é o tempo em que coincidem o momento do evento descrito e o ato de enunciação que o descreve", portanto, propõem-se desvendar quais são os percursos dos alunos para construir suas narrativas em relação ao aqui e ao agora.

\subsection{Em torno do tempo}

$\mathrm{O}$ ato de construir um texto autobiográfico torna-se pertinente ao considerar que essa construção é tomada pelas subjetivações em que o sujeito toma consciência de si para fazer seleção dos fatos que irá narrar. Por se tratar de um texto curto, em torno 30 linhas para recontar suas histórias, os alunos acabam selecionando algumas informações familiares, data e local de nascimento, idade e acontecimentos vividos nos 12, 13 anos de vida. Tal seleção é marcada por uma temporalidade específica que depende do contexto em que o narrador ocupa, já que o tempo é o agora. Contudo, confluem na narrativa alguns elementos emocionais, tratados na análise da subjetividade na seção 4.3 .

Em relação às marcas linguístico-discursivas, o advérbio "agora" marca o momento da escrita, o tempo presente, fixando a linha cronológica dos alunos. Por se tratar da narrativa autobiográfica de jovens estudantes, a ocorrência predominante é o pretérito como tempo verbal. A anterioridade do acontecimento em relação ao 
discurso obriga que os jovens evoquem suas memórias, lembranças reais, fatos vividos ou elementos recolhidos de outrem, por exemplo, de quando eram recémnascidos.

A maioria dos alunos (69\% - 29 alunos) iniciam as produções escritas (doravante PE) pela data de nascimento completa, ou seja, data, mês e ano. Essa marca indica clareza da estrutura, pois estão escrevendo em um gênero que recupera memórias, é o momento em que passam a existir, ou seja, o fato mais longínquo que conhecem sobre si mesmos.

Todos os alunos encadeiam a sequência narrativa de maneira linear. Segundo Charaudeau, o encadeamento das narrativas em questão corresponde ao tipo sucessão: "as sequências sucedem-se de maneira linear e consecutiva, cada uma constituindo o motivo que engendra a seguinte" (2016, p.170). No texto dos alunos, no entanto, não são consecutivos.

\section{Quadro 3: Textos iniciados pela data de nascimento}

\begin{tabular}{|c|c|}
\hline Identificação & Data de nascimento \\
\hline PE1 & Meu nome A. e eu nasci em 2005 no dia 31 de Março \\
\hline PE3 & Meu nome é R. R. K. I. nasci dia 07/05/17 \\
\hline PE4 & Bom obviamente tudo começou quando eu nasci, no dia 27 de Abril de 2005 \\
\hline PE7 & Meu nome é G., eu naci em 2004, tenho 13 anos, e naci dia 25/02/2004. \\
\hline PE8 & Eu sou G., tenho 12 anos e nasci em São Paulo dia 13/12/2004. \\
\hline PE9 & $\begin{array}{l}\text { Meu nome é A. A. C. A. L. e tenho } 12 \text { anos, mais tenho muito pra contar. Tudo começou quando eu nascí dia um de } \\
\text { Julho de } 2005\end{array}$ \\
\hline PE11 & Oi meu nome é A. J. J. Nasci em Fortaleza-CE em 16/03/2005. \\
\hline PE12 & $\begin{array}{l}\text { Minha vida começou no dia dia } 30 \text { de novembro de 2004, 23:56 da noite, de horário de verão. } \\
\text { É, eu praticamente nasci em dois dias. }\end{array}$ \\
\hline PE13 & Bom, nasci no dia 19 de fevereiro de 2005. \\
\hline PE14 & $\begin{array}{l}\text { Olá, meu nome é B. e tenho } 12 \text { anos de idade. Hoje contarei um pouquinho dos momentos mais marcantes da } \\
\text { minha vida. Nasci em São Paulo, Brasil em } 2004 \text { no dia } 1 \text { de dezembro. }\end{array}$ \\
\hline PE16 & Meu nome é M. E., nasci no dia 9 de janeiro de 2005 \\
\hline PE18 & Meu nome é W. P. T. nasci no dia 22/02/2005. \\
\hline PE21 & Meu nome e E. F. M. naci em Sao Paulo no dia 15/04/2005 \\
\hline PE24 & Meu nome é G. tenho 12 anos e nasci no dia 13/01/05 \\
\hline PE25 & Eu nasci dia 20 de março de 2005 \\
\hline PE28 & Oi, meu nome é I. P. M., tenho 12 anos e nasci no dia 14/01/2017 \\
\hline PE29 & Meu nome é J. L. C. A., tenho 13 anos e nasci no dia 10/12/2003. \\
\hline PE30 & Nasci dia 31.07.2005 \\
\hline PE31 & No dia 09/08/2017, eu Laura nasci \\
\hline PE33 & Meu nome é L. T. L. tenho 12 anos e nasci dia 13 de dezembro de 2004. \\
\hline PE35 & Olá meu nome é V. E. A. e eu tenho 12 anos. Nasci dia 25 de agosto de 2004. \\
\hline PE36 & Eu sou L., nascí no dia 24/11/2004 \\
\hline PE37 & Bom, meu nome é L. M. D., nasci dia 28/07/2003 \\
\hline PE38 & Eu sou o F., tenho 12 anos e nasci em 21/09/05 \\
\hline PE39 & $\begin{array}{l}\text { Minha vida tem altos e baixos, mas eu amo. Falando da minha vida vou contar ela mais profundamente. Eu nasci } \\
\text { no dia } 16 / 12 / 2004\end{array}$ \\
\hline PE40 & Nasci no dia 04/11/2004 \\
\hline PE42 & Meu nome é M., e tenho 12 anos e nasci no dia 25/02/2005 \\
\hline
\end{tabular}


Fonte: Elaborado pela autora.

A partir da data de nascimentos, o relato dos acontecimentos é posterior se pensarmos no tempo crônico, como explica Fiorin (2016; p.126), ao citar a diferenciação entre tempo crônico e tempo linguístico. O agora é a marca temporal central do eu, que narra em relação ao seu aqui e agora no momento da enunciação, ou seja, em nosso caso, no instante em que produzem as narrativas.

Ainda que iniciem com a data de nascimento marcando o momento de suas linhas do tempo, sabem que devem construir o texto em relação ao presente, tratamse de memórias, por isso usam o passado, o pretérito perfeito, pontual e acabado. Narram acontecimentos curtos e encerrados, falam de viagens, mudanças, acidentes, perdas, etc. Os alunos têm consciência de que devem selecionar os eventos mais marcantes, como bem exemplifica a PE 10 , que tem como título as " 5 coisas da minha vida."

Meu nome é J. L. C. A., tenho 13 anos e nasci no dia 10/12/2003. Minha mãe se chama C., meu pai F. e meu irmão L.. Um acidente que aconteceu comigo foi que, um dia eu estava no meu sítio e era umas 10 horas da manhã, meu primo estava me balançando em uma rede e eu cai. Sofri traumatismo craniano e sangramento. E uma coisa muito boa que aconteceu na minha vida foi que eu ganhei um irmão e outra coisa boa foi que eu ganhei uma cachorrinha que tem 3 anos e 3 meses. O meu maior sonho é morar fora do Brasil e conhecer a California. Bom, eu acho que já falei bastante coisa, então eu acabo por aqui.

Fonte: PE 10.

A aluna recupera sua data de nascimento e elenca os familiares mais próximos, mencionando nomes e parentesco, para depois narrar cinco casos: um acidente, o nascimento do irmão, a cachorrinha, o sonho de morar fora e a vontade de conhecer a Califórnia. Há dois tipos de enunciado, de estado inicialmente, ou seja, uma sequência descritiva: "Meu nome é J. L. C. A., tenho 13 anos e nasci no dia 10/12/2003. Minha mãe se chama C., meu pai F. e meu irmão L.", e posteriormente de ação, em que J. narra um acidente marcante. Ela conta sobre a cachorrinha e encerra a narrativa com um sonho. Por fim, sente necessidade de produzir um período para garantir o fechamento de sua narrativa: "Bom, eu acho que já falei bastante coisa, então eu acabo por aqui." 
$\mathrm{Na}$ progressão textual das produções escritas, nota-se o uso recorrente e preponderante de quando, tanto com conjunção quanto como advérbio, e do advérbio depois.

\begin{abstract}
Meu nome é M. E., nasci no dia 9 de janeiro de 2005, no hospital Marina as 17:13 da tarde, nesse estava um sol que meu deus do céu. $\mathrm{E}$ a maioria das pessoas da minha família são paulistas.

Um dos meus fatos mais marcantes foi quando eu vim para o Anglo 21 porque o ensino é muito bom e os meus amigos são maravilhosos e o ensino era muito diferente da minha antiga escola.

$\mathrm{O}$ outro fato foi quando eu viajei para o Beach Park, com uns amigos e eu não fiquei tão sozinha na viagem e foi a melhor viagem da minha vida, eles era muito, muito legais comigo

$\mathrm{O}$ outro fato foi quando o meu primeiro cachorro morreu, ele era da raça rottweiler, eu fiquei muito triste porque ele era o meu melhor amigo, ele me ouvia, em protegia, brincava comigo.

Ele morreu envenenado, meu avô ele tinha uma teía (onde guardava seus utencílios) nesse lugar, tinha muito rato e o meu vô passou o veneno e o meu cachorro lambeu o veneno e depois de algumas horas ele morreu. Mas agora eu sei que ele está em um lugar bem melhor."

Fonte: PE 16.
\end{abstract}

A PE 16 "Minha autobiografia", de M. E., é um bom exemplo do uso dos advérbios e das conjunções. A progressão é repetitiva e construída com a mesma expressão. Foi quando organiza os eventos, não cronologicamente, mas encerra o anterior e inicia uma nova passagem.

M. E. inicia sua narrativa com um trecho descritivo: "Meu nome é M. E., nasci no dia 9 de janeiro de 2005, no hospital Marina as 17:13 da tarde, nesse estava um sol que meu deus do céu. E a maioria das pessoas da minha família são paulistas." Trazendo inclusive dados interessantes como a presença do sol, o que certamente é parte do discurso dos familiares mais próximos. A partir de então, ela inicia o trecho de ação, narrando três acontecimentos, os dois primeiros são menos detalhados, a mudança de escola e a viagem para o Beach Park.

O episódio da morte do primeiro cachorro ganha destaque ao ter um detalhamento maior e encerrar a narrativa. A aluna faz o fechamento daquela com uma mensagem otimista, utiliza o agora para conectar o tempo linguístico com o cronológico, o que de alguma forma quebra o tom triste do último acontecimento detalhadamente narrado.

O uso do depois é recorrente em quase todos os textos; o advérbio depois serve para organizar cronologicamente os eventos sem a necessidade de uma 
marcação específica, delineando apenas a sucessão dos acontecimentos. Na PE 17 "A primeira vez que eu surfei”, de R., isso fica ainda mais explícito:

Meu nome é R. S. e eu vou contar a primeira vez que eu surfei foi quando eu tinha 10 anos, eu estava viajando para a praia, quando $o$ meu parou, e comprou uma prancha para mim e depois me disse para eu tentar pegar uma onda sozinho, mas eu não consegui.

Logo depois ele me empurrou quando a onda estava atrás de mim, praticamente em cima, assim a onda me levou até a areia. Depois eu pedi para ele me empurrar denovo e denovo assim, depois de um bom tempo eu aprendi a pegar onda.

Em fim, uma hora de viagem depois eu voltei para a minha casa e guardei a minha prancha atrás do guarda-roupa e fui comer fora.

Fonte: PE 17.

R. escolhe um acontecimento e ocupa as linhas de sua autobiografia com o detalhamento desse grande momento, que deve ter sido muito marcante, uma vez que ocupa toda a narrativa, que inclusive não conta com um trecho descritivo de apresentação, ou mesmo um fechamento.

Os alunos do $7^{\circ}$ ano têm um estilo simples, de modo que há repetições de palavras. O uso do "depois" como organizador cronológico marca a relação de posterioridade sem uma datação ou temporalidade específica, forma mais conhecida entre os alunos.

As datas são os referenciais escolhidos, assim como anos e a idade, ou seja, bons organizadores temporais, além da referência com a idade. Em PE 25 "Minha vida", de H., a organização cronológica está indicada nos anos em cada novo trecho narrativo:

Eu nasci dia 20 de março de 2005, eu não tive complicações ao nascer e meu primeiro macacão foi do Corinthians.

Minha família é composta por minha irmã, meu pai, minha mãe, minha avó e meus tios.

Eu fui pela a primeira vez a escola com 1 ano, no Colégio Mágico do Oz e continuei na mesma escola até os 10 anos.

Em 2012 foi um dos melhores anos da minha vida, pois fui para o Chile e realizei meu sonho de ver neve, e também o Corinthians foi bicampeão mundial.

No ano de 2014 eu realizei o meu desejo de ver a seleção brasileira jogar, e foi contra a Croácia na abertura da Copa do Mundo.

Em 2016 me mudei de escola e fui para o colégio Anglo 21 e adorei a nova escola, pois tenho ótimos professores como a Carol, a Mônica e o Marcio. E também grandes amigos como o B., I., P., R. e AC.."

Fonte: PE 25. 
O trecho inicial é descritivo, em que todos os acontecimentos narrados estão datados. O autor escolhe falar sobre a viagem para o Chile e o sucesso do time, em seguida fala de um desejo realizado. Por fim, recupera um acontecimento mais recente que é a mudança de escola e escolhe fechar a narrativa com a enumeração dos grandes amigos, demonstrando grande apreço pela amizade.

Na PE 14 "Uma vida de loucuras", o referencial se dá a partir da idade. O texto é construído de maneira cronológica a partir do amadurecimento do estudante, o que rememora os fatos, do mais longínquo para o mais recente:

Olá, meu nome é B. e tenho 12 anos de idade. Hoje contarei um pouquinho dos momentos mais marcantes da minha vida.

Nasci em São Paulo, Brasil em 2004 no dia 1 de dezembro. Aos meus 5 anos eu fui no meu primeiro jogo de futebol. Palmeiras contra Bragantino, foi super divertido pois fui com meu pai, irmão e vô, ganhamos e passamos na televisão.

Nos meus 9 anos, dei uma entrevista para globo pela mancha verde, por eu ser muito pequeno e ja tocar como adultos

Aos meus 11 anos coisas felizes e preocupantes aconteceram, desfilei a minha primeira vez em uma passarela do samba. $O$ evento sempre e televisionado e o mais legal, após o desfile, senti uma dor forte de madrugada na barriga, resolvi ir no hospital para ver o que havia ocorrido, fiz exame de sangue, raio $\mathrm{x}$, tomografia para descobrir que estava com apendicite. No mesmo dia em que iria fazer a cirurgia, seria a apuração dos desfiles, quando voltei da cirurgia, ainda dormindo, ouvi minha mãe falar "mancha verde campeã" o que me deixou feliz pois eu estava la, na bateria.

Nesse ano, 2016, beijei minha primeira vez, que acabou sendo marcante para mim. Viagei para os Estados Unidos, tomei advertência pela primeira vez, peguei recuperação pela primeira vez, aproveitei, ou seja, melhor ano da minha vida.

Fonte: PE 14.

Em negrito estão os referenciais temporais utilizados por B., que usa a sua idade como base temporal, evitando datação numérica, ele o faz de maneira cronológica, começando com sua data de nascimento e evoluindo para 5, 9 e 11 anos, até desembocar nos fatos mais recentes do ano retrasado, 2016. B. escolhe iniciar a sua narrativa autobiográfica direcionando ao leitor um "olá" e de alguma forma apresentando o que será desenvolvido ali, afinal uma autobiografia curta é uma narrativa de momentos marcantes do passado.

Em suma, a questão do tempo é posta como central nas narrativas, os alunos entendem a necessidade de marcar os acontecimentos e fixá-los de alguma maneira 
em uma linha temporal. A seguir, tem-se as questões espacial, analisando de qual maneira são situados os acontecimentos.

\title{
4.2. Em torno do espaço
}

A categoria do espaço é demarcada por lugares físicos nomeados, a concretude do espaço é um dado predominante para os alunos em questão. Os advérbios de lugar e os pronomes vêm associados sempre aos espaços físicos a que fazem referência. Claramente os alunos têm consciência do espaço enunciativo, o aqui que ocupam, o que faz com que as referências sejam construídas corretamente, ainda que de maneira muito simples, mas a principal marcação de espaço acontece com nomes próprios.

Para visualização da questão, há como exemplo o texto PE 27 "A minha vida como viajante":

\begin{abstract}
Meu nome é F. nasci em São Paulo tenho 12 anos, com 3 anos comecei a estudar no humbolt fiquei minha vida inteira lá. Depois eu tive que mudar de escola. Eu fui para o anlgo. Eu ja viajei para varios lugares uma delas foi a mais legal. Foi quando eu fui para Nova york, lá é muito legal é bem diferente, eu adorei. Aí eu peguei um avião e fui para Orlando eu conheci minha prima com alguns meses e adorei ela, ela é muito fofinha. Em seguida fui para uma casa alugada, meus tios ja estavam lá foi muito legal a gente ia na piscina e fazia varia coisas legais lá.
\end{abstract}

Fonte: PE 27.

O advérbio lá, que é uma referência ao não-aqui, no texto se refere a outra escola, que não é a atual, e a Nova York e Orlando, que não são o Brasil, que é o seu país de origem, de moradia, o lugar de onde fala.

Em muitos casos, a data de nascimento vem acompanhada do local de nascimento, alguns o fazem de maneira menos específica, marcando apenas cidade ou estado, e outros mencionam inclusive o nome do hospital, trazendo mais uma vez o máximo da concretude possível, afinal o nome do hospital é o dado mais específico para nomear o espaço físico do nascimento. Tal dado se mostra relevante para aparecer nas primeiras linhas da narrativa, pois marca o lugar de origem. A tabela abaixo reúne as 15 produções escritas em que o local de nascimento vem explicitado juntamente com a data, o que representa $35,7 \%$ dos textos em relação ao total. 
Quadro 4: PEs com dados iniciais de data de nascimento e local

\begin{tabular}{|c|l|}
\hline Identificação & \multicolumn{1}{|c|}{ Data e local } \\
\hline PE1 & Meu nome A. e eu nasci em 2005 no dia 31 de Março em São Paulo \\
\hline PE3 & Meu nome é R. R. K. I. nasci dia 07/05/17 em São Paulo \\
\hline PE8 & Eu sou G., tenho 12 anos e nasci em São Paulo dia 13/12/2004. \\
\hline PE11 & Oi meu nome é A. J. J. Nasci em Fortaleza-CE em 16/03/2005. \\
\hline PE14 & $\begin{array}{l}\text { Olá, meu nome é B. e tenho } 12 \text { anos de idade. Hoje contarei um pouquinho dos momentos mais } \\
\text { marcantes da minha vida.Nasci em São Paulo, Brasil em 2004 no dia 1 de dezembro. }\end{array}$ \\
\hline PE16 & Meu nome é M. E., nasci no dia 9 de janeiro de 2005, no hospital Marina as 17:13 da tarde \\
\hline PE18 & Meu nome é W. P. T. nasci no dia 22/02/2005. Eu tenho 12 anos e nasci em São Paulo mesmo \\
\hline PE21 & Meu nome e E. F. M. naci em Sao Paulo no dia 15/04/2005 \\
\hline PE28 & Oi, meu nome é I. P. M., tenho 12 anos e nasci no dia 14/01/2017 em São Paulo no hospital São luis. \\
\hline PE30 & Nasci dia 31.07.2005 no hospital Albert Einstein \\
\hline PE31 & No dia 09/08/2017, eu L. nasci no hospital Albert Einstein \\
\hline PE36 & Eu sou L., nascí no dia 24/11/2004 em Brasília \\
\hline PE38 & Eu sou o F., tenho 12 anos e nasci em 21/09/05 em Maringa/Parana. \\
\hline PE40 & Nasci no dia 04/11/2004 em São Paulo \\
\hline PE42 & $\begin{array}{l}\text { Meu nome é M., e tenho 12 anos e nasci no dia 25/02/2005, uma brincadeira que eu faço é o natal de } \\
\text { fevereiro, bom eu nasci em Belo Horizonte em Minas Gerais }\end{array}$ \\
\hline
\end{tabular}

Fonte: Elaboração feita pela autora.

Após tratar de aspectos linguísticos e suas marcas de tempo e espaço, agora a análise busca os dados subjetivos, partindo para o trabalho qualitativo. O estudo continua com base nos dados linguísticos, buscando quem são os alunos do $7^{\circ}$ ano.

\subsection{Explorando mudanças e suas memórias}

O presente item parte de uma análise qualitativa, intencionando um recolhimento de dados relevantes para conhecer os alunos em questão, e para não falar em padrões identitários, o termo usado será: padrões valorativos, ou seja, os acontecimentos mais valiosos para os 42 alunos das turmas de $7^{\circ}$ ano do Colégio Anglo21. Espera-se com isso que ao analisar as memórias individuais, a memória coletiva de jovens brasileiros de classe média alta da rede particular seja alcançada. Isto é, o que é importante para eles? De que natureza são os acontecimentos narrados? Em maioria, são fatos felizes ou tristes? Questionamentos abrangentes e investigativos que levaram aos três núcleos temáticos já mencionados.

Primeiro, é importante apresentar a concepção de narrativa utilizada. Narrar é enunciar uma experiência particular refletida sobre a qual se constrói um sentido, o qual recebe um significado. Buscar na memória aquilo que deve ser dito e o que deve ser silenciado. Queiroz (1981), uma grande pesquisadora das ciências sociais, que 
trabalhou com narrativas autobiográficas, define narração como "o relato do narrador sobre a sua existência através do tempo, tentando reconstruir os acontecimentos que vivenciou e transmitir a experiência que adquiriu" (idem, p. 19).

Com base em Charaudeau, "a narrativa é uma totalidade e o narrativo é um de seus componentes", ou seja, a narrativa descreve ao mesmo tempo ações e qualificações, isto é, "utiliza os modos de discurso que são o Narrativo e o Descritivo" (2016, p. 156).

O Descritivo se apresenta como imutável, necessitando apenas ser reconhecido, ser mostrado. O Narrativo, ao contrário, constrói um desenrolar de uma sucessão de ações que influenciam outras e são encadeadas.

Delory-Momberger expõem que a autobiográfica instala "uma hermenêutica da "história de vida, isto é, um sistema de interpretação e de construção que situa, une e faz significar os acontecimentos da vida como elementos organizados no interior de um todo" (2008, p.56-57). Portanto, a partir da leitura do corpus, visando a organização, definiu-se os acontecimentos relatados nos três núcleos temáticos: (a) viagens e deslocamentos; (b) perdas e infortúnios e (c) conquistas pessoais e alegrias. O quadro a seguir mostra a quantidade de sequências narrativas nos textos:

\section{Quadro 5: Quantidade de sequências narrativas}

\begin{tabular}{|c|c|c|}
\hline Qtd. de acontecimento relatados & Produção escrita & $\%$ \\
\hline Um & $3,5,6,17,19,20,22,23,26,28,32,34,38$ e 41. & $33 \%$ \\
\hline Dois & $9,21,24,27,29$ e 39. & $14 \%$ \\
\hline Três & $2,7,8,10,16,18,33$ e 37. & $19 \%$ \\
\hline Quatro ou mais & $1,4,11,12,13,14,15,25,30,31,35,36,40$ e 42. & $33 \%$ \\
\hline
\end{tabular}

Fonte: Elaboração feita pela autora.

Muitos alunos escolhem um acontecimento, o que demonstra o quanto 0 número pré-estabelecido de linhas pode limitar o aluno, que acaba por escolher narrar apenas um fato, sem necessariamente reconhecer que o gênero autobiográfico se constrói a partir de um inventário de acontecimentos marcantes.

Por ser uma narrativa curta, quando os alunos decidem narrar apenas um evento, colocam como o acontecimento mais forte em sua memória, seja ele por ser muito marcante ou por ser muito recente. Ao observar as narrativas com acontecimentos únicos, conseguiu-se, com mais rigor, dados sobre traços identitários, 
ou seja, o que os alunos consideram mais importante em suas vidas, a ponto de escolherem tal fato como um único acontecimento para relatarem em uma proposta de autobiografia.

Pode-se observar na PE 3 "A batida", de R., a narração de um acidente na véspera de uma viagem importante, inclusive dando ênfase para o acontecimento no título, apresentando o episódio como o único momento de sua narrativa autobiográfica.

\begin{abstract}
Meu nome é R. R. K. I. nasci dia 07/05/17 em São Paulo. Em 20/3 na vespera da viagem para o EUA, no colégio eu e os meus amigos estavamos jogando 4040. Quando derrepente o meu tenis escorregou e eu bati a cabeça na mesa de moisaco, depois na cadeira de metal e por utimo raspei a cabeça no chão, depois de 5 min os munitores Vieram e me levaram para a infermaria, a infermera disse que Tinha que ir para o hospital dar ponto, ao chegar lá a monitora ligo para minha mãe para ver se já podia começar a fazer os pontos, ela disse que sim. Foram 5 pontos, depois de 2 dias foi para a California, Texas e Orlando e por utimo São Paulo e não podia deixar de fora da minha autobiografia.
\end{abstract}

Fonte: PE 3.

R. como os outros abre a narrativa com um trecho descritivo, explicitando a data e o local de nascimento. De maneira direta, parte para a empreitada de narrar o dia 20 de março, data fatídica da batida. Trata-se de uma narrativa detalhada, trazendo minúcias, o desenvolvimento recupera os elementos de maneira linear. Ricardo não narra a viagem, menciona o destino até retornar para o seu aqui, que é São Paulo, fechando a sequência narrativa.

O fechamento da narrativa se dá com uma observação para legitimar a escolha do episódio pois "Não podia deixar de fora da minha autobiografia". Seguindo o modelo de Charaudeau (2016, p.168-167), em relação ao princípio da intencionalidade, pode-se organizar a sequência narrativa de R. da seguinte maneira:

Abertura: "Em 20/3 na vespera da viagem para o EUA, no colégio eu e os meus amigos estavamos jogando 4040..."

Falta: "Quando derrepente meu tenis escorregou e eu bati a cabeça na mesa de moisaco, depois na cadeira de metal e por utimo raspei a cabeça no chão..." 
Busca: "Tinha que ir para o hospital dar ponto, ao chegar lá a monitora ligo para minha mãe para ver se já podia começar a fazer os pontos, ela disse que sim. Foram 5 pontos..."

Resultado: Êxito: depois de 2 dias foi para a California, Texas e Orlando e por utimo São Paulo.

De maneira sintética, o texto autobiográfico se organiza em torno de um acontecimento singular e consegue construir um encadeamento mais detalhado do que as narrativas que enumeram muitos episódios diferentes.

PE 5, "Sem título", conta sobre a viagem da estudante para Campos do Jordão. A PE 6, "Sem título", narra o dia mais feliz da vida de L., quando viajou para o maior parque aquático da América Latina, como ele mesmo menciona, o Beach Park. A PE 17, de R., "A primeira vez que eu surfei" conta, como já menciona o título, aos dez anos, a sua primeira experiência com o surf. A PE 19, "Sem título", de V., fala sobre o acidente sofrido durante a viagem para Fortaleza.

PE 20, de A., "Sem título" narra a primeira viagem para os Estados Unidos, caracterizada como "bem marcante". A PE 22, de F., "Sem título", escolhe como acontecimento único um acidente doméstico enquanto brincava com o irmão, inclusive mencionando que ficou 1 mês no hospital por causa disso, dando valor ao acontecimento que inclusive deixou uma cicatriz que é visível até os dias de hoje.

A PE 23, "Minha $1^{\circ}$ mudança", de G., como já indicado no título a primeira e única troca de escola, o que é decisivo na rotina de um jovem em idade escolar. PE 26, "Sem título", de I., narra, detalhadamente, a primeira viagem aos EUA. PE 28, "Minhas férias", constrói a narrativa a partir da última viagem da família para o Guarujá no Ano novo. A PE 32, "O pior intercâmbio pra mim", de C., relata a partir dos seus sentimentos a ausência da irmã que viajou para o intercâmbio. A PE 34, "Sem título", fala sobre a mudança de Estado, saindo da capital do Rio de Janeiro e vindo para a capital paulista. A PE 38, "Sem título", fala sobre a viagem mais marcante na vida de Ítalo, quando conheceu Portugal. Por fim, a PE 41, de E. M. conta em $3^{3}$ pessoa, como já mencionado, o romance dos pais e o nascimento dos filhos.

A partir da natureza dos acontecimentos escolhidos como únicos e marcantes, a presença das viagens quase que na totalidade, ainda que, por exemplo, na PE $3, \mathrm{R}$. 
conte sobre a batida, ele o faz e coloca o evento como marcante pois ocorreu às vésperas de uma viagem importante para a família.

As PE 23, PE 22 e PE 32 são as únicas que não mencionam viagens ou mudanças, ainda que a PE 23 fale de uma mudança escolar, o seu foco durante a narração é construir um panorama emocional do acontecimento, assim como a PE 22 que trata de uma mudança de cidade. Em PE 32, o relato do sofrimento vivido com a separação durante a viagem da irmã.

As viagens e os deslocamento, juntamente com as perdas e os infortúnios são os aspectos mais marcantes para um adolescente. São os traços constitutivos da personalidade deles, que percebem as viagens como aventuras. E os acontecimentos ruins são narrados como se de alguma forma tais fatos representassem a força de terem superado esses acontecimentos.

Os alunos escolhem narrar apenas um acontecimento e o fazem de maneira menos condensada, e por isso o ritmo narrativo é mais lento. A seguir, os alunos que decidem enumerar episódios de suas vidam, narram cada um deles de maneira condensada, muitos inclusive com apenas uma frase, além de produzirem elipses, saltando temporalmente e não narrando esses intervalos.

A categorização dos textos com mais de um acontecimento narrado, exemplificados nas PEs 1 e 2 :

\begin{abstract}
Meu nome é A. e eu nasci em 2005 no dia 31 de Março em São Paulo, depois de 2 anos meu irmão R. nasceu no dia 10 de Fevereiro. Quando completei meus 5 anos comecei a fazer futsal e parei de fazer futsal no $5^{\circ}$ ano. $E$ também viajei para Gramado que fica no Rio Grande do Sul e fui no trem chamado Maria Fumaça com minha família, minha tia e minha avó e eu me diverti muito.Comecei a fazer natação aos meus 6 anos, depois de algum tempo já sabia os 4 modos e então eu parei de fazer natação.Aos meus 8 anos eu fui de carro para o hotel Tutti Resort e nesse hotel tinha um parque aquático enorme. Todos os 7 dias que fiquei por lá fiquei indo só parque aquatico e também acabei ficando com assadura, mas em compensação me diverti muito.E atualmente eu estudo no colegio Anglo 21."
\end{abstract}

Fonte: PE 1.

O texto foi categorizado no núcleo $(\mathrm{A})$ das viagens e deslocamentos e no núcleo (C) de conquistas pessoais e alegrias, pois no texto foram narradas duas viagens, uma para Gramado e outra para o Tutti Resort, além da citação das aulas de futsal e da natação, na qual após "algum tempo" o autor já dominava os 4 modos, ou seja, uma conquista da qual se orgulha. 
A PE 2, "MINHA AUTO-BIOGRAFIA", de T., foi classificada nos três eixos temáticos:

Em 2004 nasceu uma lenda (eu), T. R. P. eu sou filho de A. e da S. e tenho uma irmã T. eu tenho 13 e ela tem 10.Logo aos 4 anos meu avô faleceu, eu gostava muito dele.Mais como toda vida tem bons momentos a minha tambem tem como: quando eu mudei de escola e os meus amigos da escola antiga choraram porque eu e o $\mathrm{P}$. iriamos sair e quando eu cheguei na nova escola, me acolheram bem, tambem quando fui para os "EUA" em Orlando que lá eu fui nos parques e no meu primeiro jogo de basquete foi muito legal.

Fonte: PE 2.

O núcleo (A) quando narra a viagem para os EUA (Orlando), o eixo (B) quando menciona a morte do avô e o quanto gostava dele, registrando tal perda e, por fim, o eixo (C) quando fala da mudança da escola de forma positiva, marcando a acolhida dos novos colegas como foi recebido e a satisfação em acompanhar o primeiro jogo de basquete.

No quadro abaixo, seguem os núcleos temáticos:

Quadro 6: Divisão em núcleos temáticos

\begin{tabular}{|c|c|}
\hline Núcleos temáticos & Produções escritas \\
\hline Viagens e deslocamentos & $1,2,3,4,5,6,7,8,10,11,13,14,15,16,18,19,20,23$, \\
$\mathbf{7 6 \%}$ & $25,26,27,28,30,31,33,34,35,36,37,38,40,42$ \\
& $\mathbf{3 2}$ acontecimentos relatados \\
\hline Perdas e infortúnios & $2,3,9,10,11,12,13,14,16,18,19,22,23,24,29$, \\
$\mathbf{6 4 \%}$ & $30,31,32,33,34,35,36,37,39,40,42$ \\
& $\mathbf{2 6}$ acontecimentos relatados \\
\hline Conquistas pessoais e & $1,2,4,9,11,12,13,14,15,16,17,21,24,25,27,29,33$, \\
$36,39,40,41,42$ \\
alegrias & $\mathbf{2 2}$ acontecimentos relatados \\
\hline $\mathbf{5 2 \%}$ & \\
\hline
\end{tabular}

Fonte: Elaboração feita pela autora.

No primeiro e mais frequente eixo ( $A$ - viagens e deslocamentos) tem-se a marcação dos espaços frequentados, visitados ou adorados pelos alunos que, por serem de classe média alta em geral, têm a possibilidade de viajarem durante as férias escolares, o que na comunidade em que vivem representa algo valoroso. Tais jovens 
têm a oportunidade de conhecerem lugares que fazem parte do imaginário do brasileiro, que são representados como lugares mágicos como a Disney, a viagem citada por muitos como o destino inesquecível de suas vidas. $O$ trecho a seguir da PE 30, "Sem título", de Juliana, é exemplar nesse aspecto:

[...] A melhor viagem da minha vida foi em 2013 que fui para a Disney, porque lá e a onde os sonhos se realizam né? Eu amei quando eu vi a Tinker Bell porque eu era viciada nela. Então foi uma experiência muito boa e inesquecível.[...]

Fonte: PE 30.

"A" Disney parece ser o lugar valorizado para os alunos, como aparece em dez textos (PEs 2, 3, 10, 11, 26, 27, 30, 33, 36 e 37), mencionando a cidade americana de Orlando, onde fica o parque Disney Word. A valorização que os alunos fazem dos Estados Unidos demonstra que o "sonho americano" é um dado presente na cultura da elite brasileira, e os jovens reproduzem os valores culturais dos pais. Em $31 \%$ das narrativas, há referência positiva aos Estados Unidos, um exemplo está na PE 35:

Olá meu nome é V. E. A. e eu tenho 12 anos. Nasci dia 25 de agosto de 2004. Minha mãe e meu pai falam pra mim que esse dia é o dia do soldado, porque na segunda guerra mundial os Estados Unidos e outros paises soltaram alguns reféns na França. Bom voltando pra mim eu gosto muito de futebol e futebol americano. Eu perdi meu avo por parte de mãe aos 3 anos. Pra falar a verdade eu não lembro muito dele. Mas tirando meu avô todos os outros meus avós estão vivos. Eu já viajei pra fora do Brasil. ja fui pra Argentina, Paraguai Panama e Estados Unidos. Fui duas vezes pros Estados Unidos, e eu gostei muito. Fui pro Beto Carrero em 2017. É muito legal, é como se um parque da Disney no Brasil e eu achei genial! Quando crescer quero ser diplomata e morar no Canada Vancouver não nasci em São Paulo e sim em americana. Na verdade nasci em Campinas e fui morar em Americana.

Fonte: PE 35.

No texto, o dia do aniversário recebe uma valoração ainda mais positiva por ser o dia do soldado nos Estados Unidos, o gosto pelo futebol americano e a comparação elogiosa entre o parque Beto Carreiro e o Disney World são indícios da identidade dos jovens da classe média alta brasileira que nutrem um olhar prestigioso para os EUA.

A importância das viagens e dos deslocamentos, acredita-se, ficou suficientemente marcada quando tratamos das narrativas com um único acontecimento relatado, em que preponderantemente tratavam de viagens. 
Nos outros núcleos temáticos, falar de si torna-se uma tarefa mais complexa, pois envolve um processo de rememorar e reviver acontecimentos que fizeram parte da vida do sujeito. A fala deste que narra pode vir repleta de aspectos voltados para a emoção e hesitações, como mencionado na parte teórica do presente trabalho. Os núcleos (B) perdas e infortúnios e (C) conquistas pessoais e alegrias, em extremidades absolutamente opostas trazem à tona sentimentos fortes para os jovens, o que revela muito sobre a questão identitária do aluno de Ensino Fundamental Il de classe média alta.

Michele Petit (2013) defende a ideia de que, por meio da leitura, a interioridade do ser humano é modificada, permitindo ao leitor - sobretudo aquele que vive em espaços de crise - que recupere um sentimento de continuidade. Pode-se dizer que "para além desses contextos dramáticos, a leitura como o jogo, é uma maneira de se reafirmar, dia após dia" (p. 91).

A escrita é a potência máxima disso, a partir da leitura se constrói a produção de texto de forma natural e espontânea, fazendo com que a dupla leitura/escrita seja o suporte de discurso de si mesmo, a literatura faz com que o leitor que vive numa situação adversa possa ver o mundo de outra maneira, sobretudo em razão de sua capacidade de fornecer representações simbólicas, necessárias, segundo a autora, à existência humana:

\footnotetext{
Não importa o meio onde vivemos e a cultura que nos viu nascer, precisamos de mediações, de representações, de figurações simbólicas para sair do caos, seja ele exterior ou interior. O que está em nós precisa primeiro procurar uma expressão exterior, e por vias indiretas, para que possamos nos instalar em nós mesmos" (PETIT: 2013, p. 115).
}

Mais da metade dos textos pontuam acontecimentos como mortes e perdas, e fica claro que é uma forma de registrar algo problemático que foi vivido, narrando um trauma, como a PE 36, de L., intitulada "Desventuras em série", o que marca a força dos acontecimentos negativos:

Eu sou L., nascí no dia 24/11/2004 em Brasília, morei lá até meus 5 anos e me mudei para o Rio de Janeiro. Dia 17/04/11 meu tio faleceu, ele estava com cancêr, mas agora ele está em um lugar melhor assim como minha tia. No ano de 2013 fui ao México, conheci um pouco da cultura e as piscinas de lá são enormes.Em 2014 próximo a meu aniversário nos fomos a Disney, nos fomos para Orlando e visitamos vários parques lá, que foi uma experiência e tanto.Em 2014, mesmo 
ano de Orlando me mudei para SP e fiz muitos amigos.Em 2015, o meu tio morreu de cancêr, e foi bem difícil de superar.Em 2016 fui pra Angra dos Reis, em RJ nós achamos um celular no chão, no Reivellón em RJ e nós esperamos alguém ligar para pegar o celular e de volta ele nos deu uma viagem para Angra dos Reis. $\mathrm{Na}$ ida o lugar era lindo bonito e você tinha que pegar uma balça, só que na volta pegamos muita chuva e a balça quase virou.

Fonte: PE 36.

O título faz referência a uma série de treze livros escrita por Lemony Snicket, pseudônimo do autor americano Daniel Handler. A obra trata das aventuras de três crianças que após a morte de seus pais em um incêndio se veem sozinhas. Existem adaptações para o cinema e, recentemente, uma série produzida pela Netflix, o que demonstra que o aluno tem esse repertório em seu horizonte.

Luan inicia a sua narrativa com um expediente descritivo, mencionando sua data de nascimento e os lugares onde morou. A sequência é construída cronologicamente, encadeando os acontecimentos de forma sucessiva. A abertura é realizada com os acontecimentos mais longínquos que são narrados, como a morte do tio em 2011, a viagem ao México em 2013, a viagem para Orlando (EUA) e a mudança para São Paulo em 2014, a morte também por câncer de outro tio em 2015, e por fim, os infortúnios vividos em 2016 quando foi para Angra dos Reis, que é o expediente narrativo mais desenvolvido.

\section{Abertura: "Em 2016 fui pra Angra dos Reis, em RJ”.}

Falta: "nós achamos um celular no chão, no Reivellón em RJ".

Busca: "nós esperamos alguém ligar para pegar o celular e de volta"..

Resultado: Êxito: "ele nos deu uma viagem para Angra dos Reis. Na ida o lugar era lindo bonito e você tinha que pegar uma balça, só que na volta pegamos muita chuva e a balça quase virou".

Não se pode afirmar que L. menciona apenas acontecimentos negativos, uma vez que menciona também viagens. Nota-se que as duas mortes vêm com um registro desse processo de entendimento: "mas agora ele está em um lugar melhor assim como minha tia" e "e foi bem difícil de superar". 
Quando ele afirma que foi difícil superar a perda, trata-se de um processo de aceitação pessoal, é importante marcar a dificuldade de perder alguém. Petit cita André Green, "Somos uma espécie dominada pelo relato [...] nossa espécie parece estar atada à necessidade de uma regurgitação linguística de sua experiência" (2013, p.77), trazer a possibilidade da produção textual em que está autorizada a verbalização de momentos críticos para a escola é algo potente.

Outro exemplo disso, é a PE 32, da C., "O pior intercâmbio para mim", em que ela escolhe como acontecimento único a ser narrado o seu sofrimento com o intercâmbio da irmã.

\begin{abstract}
Oie, meu nome é C., tenho 12 anos, hoje vim contar uma história que aconteceu comigo.No meio de 2016, minha irmã mais velha de 16 anos na época, foi fazer intercâmbio. Parece algo simples ficar longe do irmão que sempre está brigando com você, mas não é tão simples assim.Minha irmã faz parte da minha vida, então quando ela foi, no começo foi normal, mas depois de um mês, comecei a ficar chateada, contava os dias para ela voltar, ligava toda hora, mandava várias mensagens.Depois de 3 meses comecei a ficar muito triste, não dormia, não queria sair da cama, tudo pra mim estava errado e estranho.O tempo previsto de intercâmbio era de 1 ano, mas no $4^{\circ}$ mês minha irmã ligou dizendo que iria voltar e que estava com saudades, meu coração começou a bater mais forte, comecei a sentir que tudo voltaria a ser perfeito como antes.Minha irmã chegou e tudo ficou melhor e divertido de novo.Por causa do intercâmbio, todos achavam que minha irmã voltaria mais madura, mas ela continua parecendo uma criança quando faz bobagem comigo. Eu amo minha irmã, mesmo ela me tirando do sério ás vezes.
\end{abstract}

Fonte: PE 32.

Abertura: "No meio de 2016, minha irmã mais velha de 16 anos na época, foi fazer intercâmbio...".

Falta: "Depois de 3 meses comecei a ficar muito triste, não dormia, não queria sair da cama, tudo pra mim estava errado e estranho...". 
Busca: "no $4^{\circ}$ mês minha irmã ligou dizendo que iria voltar...".

Resultado: Êxito: Minha irmã chegou e tudo ficou melhor e divertido de novo. Por causa do intercâmbio, todos achavam que minha irmã voltaria mais madura, mas ela continua parecendo uma criança quando faz bobagem comigo".

Ela organiza esse sentimento dentro de si, é como se ao relatar, algo fosse amenizado dentro de si. Ela faz afirmações sobre transformações vividas e emoções. Segundo Petit (2013, p.110), buscam-se palavras para dominar os medos, e responder perguntas que atormentam. Parece-nos clara a função reparadora da escrita, principalmente por meio do texto autobiográfico.

Em PE 12, "Sem título", A. narra três acontecimentos tristes:

Minha vida começou no dia 30 de novembro de 2004, as 23:56 da noite, de horário de verão. É, eu praticamente nasci em dois dias.

Eu infelizmente nasci com 8 meses, por isso, nasci com um pulmão incompleto. Após 10 dias na UTI, o sofrimento acabou.

Os anos passaram cheios de alegria.

$2011 \ldots$

Um dos anos mais felizes.

Meu irmão, Arthur nasceu dia 23/06/11. Na hora que peguei ele colo, melhor sensação.

O dia mais feliz da minha vida.

2012 ...

Meu avô Manuel, de 80 anos, sofreu um infarto. Dia muito triste. $2014 \ldots$

Agora, minha avó. Ela tinha um câncer de pulmão nu. 4. Já não tinha mais cura. Então, desligaram os aparelhos, e ela se foi.... É isso.

André abre a narrativa com a narração do nascimento, a datação e posteriormente o fato de ter quase nascido em dois dias, na sequência vê a necessidade de marcar a dificuldade ao nascer, o que os familiares devem ter relatado para ele, parece que a intenção é demonstrar sua força, afinal, foi um desafio nascer e estar vivo. Depois de anos "cheios de alegria" que sofrem uma elipse, ele finaliza a narrativa com duas grandes perdas, a do avô em 2012, e a da avó em 2014. O avô parece ter sido uma perda repentina, que inclusive é marcada com um "Dia muito triste". A perda da avó parece menos surpreendente por ser um câncer grave, inclusive detalhando o número dele, ao não ter mais cura o processo natural foi a sua ida.

Ao comunicar uma perda, os alunos procuram uma forma de amenizar a situação, justificando o acontecimento, o que possivelmente, é a reprodução do discurso do adulto para acalmar o jovem em um momento de perda. 
PE 16, "Minha autobiografia", de M. E., tal elemento é absolutamente visível:"[...]e depois de algumas horas ele morreu. Mas agora eu sei que ele está em um lugar bem melhor."

Os infortúnios registrados são variados, podemos citar como exemplo a PE 30 "Sem título", em que Juliana inicia sua narrativa com uma questão muito pessoal e complicada, apesar de ter como desfecho algo positivo.

[...] Não parece e porque eu sou muito baixa é isso me atrapalha muito, mas sempre tive muito apoio da minha família, e principalmente da minha irmã. Então eu e a minha família decidimos que eu ia começar a fazer tratamento de crescimento. Foi a melhor decisão da minha vida. $\mathrm{E}$ isso me ajudou a ter mais responsabilidade porque preciso aplicar 0 remedio todos os dias.

Fonte: PE 30.

Registrar o fato parece ser importante para demonstrar a sua força, algo constitutivo de sua personalidade, apesar de ser algo muito ruim, que a atrapalha tanto, ela recebe apoio da família e consegue ver o quanto aprendeu.

Sobre o núcleo $(\mathrm{C})$ das conquistas e das alegrias, percebe-se que os meninos têm grande apreço pelo futebol e as meninas pelos cães de estimação. Por exemplo, nas PEs 21 e 9:

Meu nome e Enzo Ferreira Murgolo naci em Sao Paulo no dia 15/04/2005 e torço pelo time do estado, eu antigamente não gostava de futebol eu acho que virei sãopaulino por causa do meu pai já que toda família eram torcedor fanatico ian em todos os jogo no MOROMBI ou assistiam pela TV, sendo hoje que sou socio do clube ao lado do estadio, onde vou praticamente em todos os jogos com meus amigos. Hoje em dia eu adoro jogar futebol e tambem acompanhar todas as noticia dele e jogo todo os dias na escola ou no clube.[...]

Fonte: PE 21.

Enzo descreve a sua relação com o futebol, trazendo com alegria o fato de ter desenvolvido o gosto pelo futebol, o que fez com que estivesse mais inserido na família que já era torcedora fanática.

[...] Agora para não ficar só na tristeza vou contar uma coisa feliz. Uma coisa que pra mim é muito legal mas pra algumas pessoas nem tanto , foi quando eu fui para o final da Sul-Americana em um campeonato de futebol. O São Paulo foi jogar com os Tigres e venceu por WO pois eles foram antes de acabar o jogo, e toda a galera ficou feliz e é isso. Então depois disso teve mais alegria, mais não da pra contar aquí pois ia ficar um texto muito longo então é assim que acaba a minha autobiografia.[...]

Fonte: PE 9. 
$\mathrm{Na}$ PE 9, A. reconhece que nem todas as pessoas gostam tanto de futebol, mas que para ele foi uma alegria estar na final de um campeonato de futebol. Já para os textos das meninas, percebe-se uma constante sobre os animais de estimação, um bom exemplo é a PE 24, de G.:

\begin{abstract}
Meu nome é G. tenho 12 anos e nasci no dia 13/01/05, moro com minha mãe, pai irmã e tenho um cachorro. Minha mãe se chama L. ela tem 46 anos, meu pai se chama A. ele tem 47 , minha irmã se chama G. ela tem 15 anos e por ultimo o meu cachorro se chama Floquinho ele tem 1 ano e 5 meses.[...] A melhor coisa que aconteceu comigo foi quando eu ganhei ganhei o meu cachorro. O meu sonho é conhecer o elenco de "The Vampire Diares"
\end{abstract}

Fonte: PE 24.

Na maioria das narrativas autobiográficas, há várias abordagens temáticas, 0 que indica que a vida é composta de momentos, alegres e tristes, como na PE 2, "Minha auto-biografia", em que Thiago relata o falecimento do avó e em seguida enumera bons acontecimentos:

Logo aos 4 anos meu avô faleceu, eu gostava muito dele.Mais como toda vida tem bons momentos a minha tambem tem como: quando eu mudei de escola e os meus amigos da escola antiga choraram porque eu e o Portella iriamos sair e quando eu cheguei na nova escola, me acolheram bem, tambem quando fui para os "EUA" em Orlando que lá eu fui nos parques e no meu primeiro jogo de basquete foi muito legal.

Fonte: PE 2.

A percepção sobre a vida ainda é ingênua, já que são jovens que em média têm 12 anos, estão entendendo o turbulento período de entrada na adolescência e o que é a vida, contudo, 29 textos narram acontecimentos de diferentes núcleos temáticos, representando $69 \%$ dos jovens, ou seja, eles percebem que a vida tem acontecimentos felizes e planejados, como momentos repentinos e difíceis.

A atividade mostrou-se frutífera pois todos os alunos conseguiram construir textos sobre si mesmos em primeira pessoa, apesar da hipótese de se tratar de temas como a sexualidade, percebe-se que essa questão ainda é discreta, ou não se sentiram à vontade para tratar sobre isso, devido aos índices muito discretos, apenas a PE 16, de B., registra o primeiro beijo, por exemplo.

As relações parentais ou de amizade complicadas também foram colocadas como temáticas possíveis. Nota-se que as famílias são citadas, ainda que sem muito detalhamento, pais, irmãos, avós e tios aparecem como elementos descritivos, pouco se desenvolve sobre os relacionamentos, apenas dois casos. A PE 5, de L., "Sem 
título", que traz: "Eu tenho duas irmas K. de 2 anos e a L. de 16 anos. A K. é muito legal ela brinca comigo, come comigo, me acompanha pra ir no banheiro e fica comigo. Já a L. neinha dá bola.", ou seja, registra a falta que sente da atenção da irmã, tendo um contato mais próximo apenas com a irmã mais nova.

Outro registro acontece na PE 23, de G., "Minha 1ํㅡㄹ mudança", em que há o registro de um caso de bullying:

Infelizmente eu perdi o contato com elas e por um bom tempo ficamos sem falar.

Uma delas fez bullying comigo e com a minha irmã quando eu estava no $6^{\circ}$ e ela no 4 .

A outra amizade que eu fiz, eu não falo mais, mas gostaria de falar.

Fonte: 23.

Os alunos utilizaram o espaço narrativo proposto para falar sobre as viagens, os acontecimentos negativos e suas vitórias, o que de alguma forma estava sugerido nos textos apresentados nas aulas de leitura. Conclui-se que a atividade serviu como base estrutural, ou seja, em relação ao modelo de organização e estrutura composicional, muito mais do que como sugestão temática. A hipótese aqui é que por se tratar de textos adultos, os alunos apesar de acharem interessante não compartilham de vivências tão profundas.

Retoma-se a definição de narrativa a partir de uma abordagem psicológica para a finalização desta dissertação. O conceito de narrativa não é simples e vem ganhando diferentes acepções conforme se adotam diferentes paradigmas e molduras teóricas nas várias disciplinas que a investigam. Do ponto de vista linguístico, acredita-se já ter aqui exposto o suficiente, mas analisando melhor, a abordagem psicológica da narrativa foram surgindo.

Para Maria da Conceição Moita, a pesquisa autobiográfica tem uma metodologia com potencialidades de diálogo entre o individual e o sociocultural, pois "põe em evidência o modo como cada pessoa mobiliza seus conhecimentos, os seus valores, as suas energias, para ir dando forma à sua identidade, num diálogo com os seus contextos" (in Nóvoa,1995, p.113). Tem-se a visão que o pensamento e o texto narrativo apresentam características que permitem aos seres humanos lidar com a heterogeneidade, com os dilemas e com questões íntimas.

A ação de relatar é importante quanto o relato em si, quanto ao conteúdo ou a sua complexidade. $O$ contexto da ação discursiva e do trabalho com as palavras e 
gestos torna-se fundamental para entender a autocompreensão e a produção de sentido sobre o mundo que operam nas narrativas autobiográficas, mesmo sendo de jovens em fase de amadurecimento.

Atribuir sentido à própria vida mediante narração é justamente criar discursivamente essa realidade, reivindicando certa imagem de si e provocando um conjunto de efeitos sobre si mesmo e sobre os outros com quem se convive. Como dizem Brandão e Germando: "Quem eu digo ser orienta a minha ação e é capaz de orientar a ação alheia”.

Por fim, uma citação de Nóvoa (2001):

\begin{abstract}
é preciso reconhecer que mesmo os mais impenitentes críticos do gesto (auto)biográfico a ele se consagraram uma ou outra vez. Tudo se decide na consciência do acto. No seu equilíbrio e sensatez [...]. Não se trata de uma mera descrição ou arrumação de factos, mas de um esforço de construção (e de reconstrução) dos itinerários passados. É uma história que nós contamos a nós mesmos e aos outros. O que se diz é tão importante como o que fica por dizer. O como se diz revela uma escolha, sem inocências, do que se quer falar e do que se quer calar (p.7-8).
\end{abstract}

A (re)construção do passado é seletiva, realizada a partir da presente, pois é este que aponta o que é importante e o que não é, não se trata de descrição, mas de interpretação. Catroga (2001), em artigo intitulado Memória e História, também aborda a memória como sendo uma construção seletiva do sujeito, eis que, na visão do autor, com a qual concorda-se aqui, a memória é, mais que um mero registro, pois esta objetiva-se "numa narrativa coerente que, em, retrospectiva, domestica o aleatório, o casual, os efeitos perversos do real passado quando este foi presente, actuando como se, no caminho, não existissem buracos negros deixados pelo esquecimento" (p. 46).

Para Bosi, "na maior parte das vezes, lembrar não é reviver, mas repensar, com imagens e ideias de hoje, as experiências do passado", ou seja, "A lembrança é uma imagem construída pelos materiais que estão agora à nossa disposição no conjunto de representações que povoam nossa consciência atual" (1994, p. 55).

Os jovens têm o que dizer e querem ser ouvidos, professores, pais e familiares devem dar ouvidos ao que eles têm a dizer. É importante para que cresçam donos de seus discursos e para que percebam que todas as experiências são significativas, seja na escola ou no ambiente doméstico. 


\title{
CONSIDERAÇÕES FINAIS
}

Como últimas palavras, o principal trecho da obra de Rainer Maria Rilker, em Cartas a um jovem poeta, que serviu como inspiração tanto na fase de idealização quanto na execução, e, inclusive apareceu nas epígrafes dos capítulos:

\begin{abstract}
E se, desse ato de se voltar para dentro de si, desse aprofundamento em seu próprio mundo, resumido em versos, o senhor não pensará em perguntar a alguém se são bons versos. [...] Uma obra de arte é boa quando surge de uma necessidade. É no modo como ela se origina que se encontra seu valor, não há nenhum outro critério. Por isso, prezado senhor, eu não saberia dar nenhum conselho senão este: voltar-se para si mesmo e sondar as profundezas de onde vem a sua vida; nessa fonte o senhor encontrará a resposta para a questão de saber se precisa criar. Aceite-a como ela for, sem interpretá-la. Talvez ela revele que o senhor é chamado a ser um artista. Nesse caso, aceite sua sorte e a suporte, com seu peso e sua grandeza, sem perguntar nunca pela recompensa que poderia vir de fora. Pois o criador tem de ser um mundo para si mesmo e encontrar tudo em si mesmo e na natureza, da qual se aproximou (RILKE, 2009, p. 26).
\end{abstract}

A partir das palavras de Rilke, que aconselha o jovem poeta a se voltar para si mesmo e sondar as profundezas de onde vem a sua vida, pois ali terá contato com o que de fato precisa saber e o que é criar. Portanto, essa é a força da autobiografia para os jovens, o envolvimento com a língua materna e com suas trajetórias de vida. O jovem realiza no ato de escrever e amplia seu repertório de visão de mundo, e tem contato com o subjetivo, ainda que de maneira simplista por se tratarem de autores de cerca de 12 anos, mas olham para o íntimo, para questões singulares que guardam dentro de si.

Por essa mesma razão, situam-se na coletividade, ou seja, percebem-se como grupo e têm a possibilidade de entender o mundo e o mais importante, a si mesmos, sob um novo prisma.

É o movimento de interiorização que mais importa, mais do que qualquer outro produto, aqui no caso, um texto verbal. Lejeune, citando Stuart Hall, afirma que "a identidade vem sendo cada vez mais definida social, historicamente ou mesmo 'narrativamente', e não necessariamente a partir de seu referencial biológico ou de território" (LEJEUNE, 2008, p. 46). O que parece ser algo muito grande e importante para as nações, fazendo com que preconceitos cada vez mais sejam desconstruídos e desenvolvendo o sócio e o emocional, os jovens que passam pela experiência 
autobiográfica, estes que olham para si, percebem que existem muitos elementos que os constituem, as experiências vividas os transformaram durante a vida.

Sem encerramento de tal reflexão, voltando-se para os textos analisados, temse a percepção de que diante dos textos pode-se apontar muitas tendências e característica típicas dos estudantes de $7^{\circ}$ ano, e porque não dizer de tendências de jovens no século XXI.

Enxerga-se, antes de mais nada, a importância da atividade na medida que proporciona uma experiência de reflexão rica aos alunos que se mostraram competentes na escrita e na organização de suas memórias. Demonstrando que valorizam suas famílias e sofrem com a perda de entes queridos, principalmente os avós, e que escrever sobre isso tem uma função reparadora, fazendo com que, de alguma forma, tragam para o papel tais situações, reavaliando-as.

As viagens e os lugares que visitam tornam-se experiências muito significativas, dignas de estarem pontuadas em uma narrativa curta. Assim, quando as perguntas iniciais da pesquisa retornam à mente, tem-se que elas foram respondidas.

Conseguiu-se explicitar em que medida o texto autobiográfico é relevante para o ensino de produção escrita, bem como trazer reflexões sobre como os alunos escrevem as suas memórias, em relação ao tempo, ao espaço e à pessoa, e por fim, pontuar quais são alguns dos valores identitários dos estudantes do Ensino Fundamental II.

Em suma, a presente dissertação trata da pesquisa autobiográfica com destaque para as narrativas como um de seus instrumentos de coleta de informações, bem como a memória como elemento-chave para a formação da identidade. Inclusive, é a memória do narrador (reconstrutiva da significação de suas vivências) e o olhar interpretativo que se conectam e se complementam para melhor compreensão de dimensões da realidade pesquisada, a realidade do aluno de $7^{\circ}$ ano em uma escola particular da zona sul de São Paulo, tanto na perspectiva pessoal/social do narrador, como na perspectiva contextual da qual essa individualidade é produto/produtora.

Além disso, assim como Petit (2013) diz que a "leitura pode ser, em qualquer idade, um recurso privilegiado para elaborar ou manter um espaço próprio, um espaço íntimo, privado", um "teto todo seu", citando Virginia Woolf, enxerga-se a escrita biográfica como a maneira mais eficaz de acessar um território tão pessoal sem deixar 
de ajudar na elaboração da individualidade dos jovens que entra para a fase da adolescência.

Finalmente, não se acredita que o trabalho com a autobiografia acaba em si, mas sim que é uma porta aberta de acesso a outras ressonâncias que despertam diversas associações, emoções, outros pensamentos, que podem transformar a relação entre o aluno e a escrita, por meio da leitura e da produção textual do texto autobiográfico. 


\section{REFERÊNCIAS}

AMORIM, M. Cronotopo e exotopia. In: BRAIT, B. (Org.). Bakhtin: outros conceitos chave. São Paulo: Contexto, 2006.

ANTUNES, I. Aula de português: encontro e interação. São Paulo: Parábola Editorial, 2003 (Série Aula; 1).

ARFUCH, Leonor. $O$ espaço biográfico: dilemas da subjetividade contemporânea. Tradução de Paloma Vidal. Rio de Janeiro: EdUERJ, 2010.

BAKHTIN, M. Estética da criação verbal. Tradução de Paulo Bezerra São Paulo: Martins Fontes, 2011.

- Para uma filosofia do ato responsável. Tradução aos cuidados de Valdemir Miotello e Carlos Alberto Faraco. 2. ed. São Carlos: Pedro e João, 2012.

. Questões de Literatura e Estética (A Teoria do Romance). São Paulo: Editora da HUCITEC, 2002.

BARROS, Mariana Luz Pessoa. A arquitetura das memórias: Um estudo do tempo no discurso autobiográfico. Universidade de São Paulo. São Paulo, 2006.

BEZERRA, Maria Auxiliadora. Ensino de língua portuguesa e contextos teóricometodológicos. In: DIONISIO, A. P.; MACHADO, A. R.; BEZERRA, M. A. (Org.). Gêneros textuais \& ensino. 2.ed. Rio de Janeiro: Lucerna, 2002. p. 37-46.

BOLÍVAR, A. (2002). ¿De nobis ipsis silemus? Epistemología de la investigación biográfico-narrativa. Revista Electrónica de Investigación Educativa (REDIE), vol. 4 (1). Disponível em: < http://www.scielo.org.mx/scielo.php?pid=S160740412002000100003\&script=sci_abstract>. Acesso em: ago. 2017.

BOSI, Ecléa. Memória e Sociedade: lembranças de velhos. São Paulo: Companhia das Letras, 1994.

Ateliê Editorial, 2003.

O Tempo Vivo da Memória: Ensaios de Psicologia Social. São Paulo:

BRAIT, B. (Org.). Bakhtin e o Círculo. São Paulo: Contexto, 2009.

BRANDÃO, Thaís Oliveira; GERMANDO, Idilva Maria Pires. Experiência, memória e sofrimento em narrativas autobiográficas de mulheres. Psicol. Soc. vol.21 no.1 Florianópolis Jan./Apr. 2009. Disponível em: $<$ http://www.scielo.br/scielo.php?script=sci arttext\&pid=S010271822009000100002>. Acesso em: mar. 2018. 
BRASIL. Estatuto da criança e do adolescente: Lei federal no 8069, de 13 de julho de 1990. Rio de Janeiro: Imprensa Oficial, 2002.

BRITTO, L. P. L. Fugindo da norma. São Paulo. Átomo, 1991.

BRUNER, J. A cultura da educação. Tradução de Marcos Domingues. Porto Alegre: Artmed, 2001.

CALVINO, I. Por que ler os clássicos? São Paulo: Companhia das Letras, 2007.

CAMPOS, M. I. A questão da arquitetônica em Bakhtin: um olhar para materiais didáticos de língua portuguesa. 2012. Disponível em: $<$ http://revistas.usp.br/flp/article/viewFile/59913/63022>. Acesso em: ago. 2017

CATROGA, F. Memória e História. In: PESAVENTO, S. J. (Org.). Fronteiras do Milênio. Porto Alegre: Editora da Universidade/ UFRGS, 2001.

CHARAUDEAU, P.; MAINGUENEAU, M. Dicionário de análise do discurso. São Paulo: Contexto, 2004

2016.

Linguagem e discurso: modos de organização. São Paulo: Contexto,

COSTA-HÜBES, T. C. Os gêneros discursivos como instrumentos para o ensino de Língua Portuguesa: perscrutando o método sociológico Bakhtiniano como ancoragem para um encaminhamento didático-pedagógico. In: NASCIMENTO, E. L. do; ROJO, H. R. (Orgs.). Gêneros de Texto/Discurso e os desafios da contemporaneidade: São Paulo: Pontes Editora, 2014.

DELORY-MOMBERGER, Christine. Biografia e educação: figuras do indivíduoprojeto. Tradução de Maria da Conceição Passeggi, João Gomes da Silva Neto, Luiz Passeggi. Natal, RN: EDUFRN; São Paulo: Paulus, 2008.

DOLZ, J.; SCHNEUWLY, B. Gêneros orais e escritos na escola. Tradução e Organização de Roxane Rojo e Glaís Sales Cordeiro. Campinas: Mercado de Letras, 2004.

ESTEBAN, M. P. S. Pesquisa qualitativa em Educação: fundamentos e tradições. Porto Alegre: AMGH, 2010.

FARACO, C. A. Português: língua e cultura. $3^{a}$ série. Ensino Médio. Manual do Professor. Curitiba: Base Editorial, 2005.

. Aspectos do pensamento estético de Bakhtin e seus pares. Letras de Hoje, Porto Alegre, v. 46, n. 1, p. 21-26, jan./mar. 2011.

FERRAROTI. F. Sobre a autonomia do método biográfico. In: NÓVOA, António;

FERREIRO, Emília. Reflexão sobre alfabetização. 24. ed. São Paulo: Cortez, 2001. 
FINGER, M. (Org..). O método (auto) biográfico e a formação. Natal, RN:

FIORIN, José Luiz. As astúcias da enunciação. São Paulo, Ática, 1996 [Ed. Contexto. 2016].

. Introdução ao pensamento de Bakhtin. São Paulo: Ática, 2006.

FLEURY, Sêneca Renato. Livro didático. Revista Brasileira de Estudos Pedagógicos, vol. XXXV, n. 82, abr./jun. 1961, p. 174-177. Disponível em: <http:// www.publicacoes.inep.gov.br/arquivos/\%7B6DD53B3D-E90B-48E3-87FA9E13288093E7\%7D_no﹎82_V._35.pdf>. Acesso em: abr. 2018.

FOUCAULT, Michel. A escrita de si. In: O que é um autor? Lisboa: Passagens. 1992. pp. 129-160. Disponível em: http://eps.otics.org/material/entrada-outrasofertas/livros/a-escrita-de-si-michel-foucault>. Acesso em mar. 2018.

FREITAS, M. T. A. Vygotsky e Bakhtin - psicologia e educação: um intertexto. São Paulo/Juiz de Fora: Ática/EDUFJF, 1994.

GERALDI, João Wanderley. Portos de passagem. 2. ed. São Paulo: Martins Fontes, 1993.

. O texto na sala de aula. São Paulo: Ática, 1997.

GRILLO, Sheilla. Gêneros primários e gêneros secundário no círculo de Bakhtin: implicações para a divulgação científica. Revista de Linguística Alfa. V52n1, 2008. Disponível em: <http://piwik.seer.fclar.unesp.br/alfa/article/view/1467/1172>. Acesso em: abr. 2018

$\mathrm{KOCH}$, Ingedore Villaça. O texto e a construção de sentidos. 9. ed. São Paulo: Contexto, 2007.

LEJEUNE, p. Le Pacte Autobiographique. Paris, Seuil, 1975.p.13-45.

. L'autobiographie en France. 2. ed. Paris: Armand Colin, [1971] 1998a. In: PACE, Ana Maria. Lendo e escrevendo sobre o pacto autobiográfico de Philippe Lejeune. Dissertação de mestrado. Universidade de São Paulo, 2012.

O pacto autobiográfico: de Rousseau à Internet. Tradução de Jovita Maria Gerheim Noronha, Maria Inês Coimbra Guedes. Belo Horizonte: Editora da UFMG, 2008.

MENESES, U. T. B. A história, cativa da memória? para um mapeamento da memória no campo das Ciências Sociais. Revista do Instituto de Estudos Brasileiros, São Paulo, n. 34, 1992.

MEURER, J. L. Gêneros Textuais na Análise Crítica de Fairclough. In: MEURER, J.L.; BONINI, A.; MOTTA-ROTH, D. (Orgs.). Gêneros: teorias, métodos e debates. São Paulo: Parábola Editorial, 2005. 
MITIDIERI, André Luis. Da produtividade dialógica no espaço biográfico. Bakhtiniana, Rev. Estud. Discurso [online]. 2013, vol.8, n.1, pp.140-156. ISSN 2176-4573. Disponível em: http://dx.doi.org/10.1590/S217645732013000100009>. Acesso em: fev. 2018.

MOITA, M. C. Percursos de Formação e de Trans-Formação. lu NÓVOA, A Vidas de Professores. Porto: Porto Editora, 1995.

MORSON, Gary Saul; EMERSON, Caryl. Mikhail Bakhtin: criação de uma prosaística. Tradução de Antonio de Pádua Danesi. São Paulo: Edusp, 2008.

NÓVOA, A Prefácio. lu: ABRAHÃO, M.H.M.B. (Org.). História e Histórias de Vida destacados educadores fazem a história da educação rio-grandense. Porto Alegre: EDIPUCRS, 2001. In: Memória, narrativas e pesquisa autobiográfica, de Maria Helena Menna Barreto Abrahão.

PINHEIRO, O. de G. Entrevista: uma prática discursiva. In M. J. Spink (Org.) Práticas discursivas e produção de sentidos no cotidiano: aproximações teóricas e metodológicas (pp.183 -214). São Paulo: Cortez, 1999.

PENNEBAKER J. Confession, inhibition, and disease. In L Berkowitz. Advances in experimental social psychology. New York, Academic Press, 1989 p. 211-244.

PEREIRA, R. C. M. Práticas de escrita e reescrita na sala de aula: desafios para alunos e professores. In: (Org.). Ações de linguagem: da formação continuada à sala de aula. João Pessoa: Editora Universitária UFPB, 2010. p.172195.

PETIT, Michele. Leituras: do espaço intimo ao espaço público. Tradução de Celina Olga de Souza. São Paulo, editora 34, 2013.

POSSENTI, S. Por que (não) ensinar gramática na escola. Campinas, SP: ALB: Marcado das Letras, 1997.

QUEIROZ, Maria Isaura Pereira de. Variações sobre a técnica de gravador no registro da informação viva. Cadernos do CERU, São Paulo, n. 16, p. 107-115, nov. 1981.

RICOEUR, P. O si-mesmo como um outro. Tradução de Lucy Moreira Cesar. Campinas: Papirus, 1991.

A memória, a história e o esquecimento. Campinas: Unicamp, 2010.

RILKE, Rainer Maria. Cartas a um jovem poeta. Tradução de Pedro Süssekind. Porto Alegre: L\&PM, 2009. 
ROJO. R.H.R. Gêneros do discurso no círculo de Bakhtin-ferramentas para a análise transdiciplinar de enunciados em dispositivos e práticas didáticas. UNICAMP, 2007. Disponível em: $<$ http://s3.amazonaws.com/academia.edu.documents/11735524/117.pdf?AWSAcces sKeyld=AKIAJ56TQJRTWSMTNPEA\&Expires $=1484151964 \&$ Signature $=7$ A6lqm6uB KaM9cbg5D0Y8meHJv0\%3D\&responsecontentdisposition=inline\%3B\%20filename\% 3DGENEROS DO DISCURSO NO CIRCULO DE BAKHTI.pdf>. Acesso em: mar. 2018.

ROJO, R. H. R. (Org.); BATISTA, A. A. G. (Org.). Livro Didático de Língua Portuguesa, Letramento e Cultura da Escrita. 1. ed. Campinas: Mercado de Letras, v. 1 , p. $320,2003$.

ROJO, Roxane; CORDEIRO, Glaís Saler. Apresentação: gêneros orais e escritos como objetos de ensino: modo de pensar, modo de fazer. In: SCHNEUWLY, B.; DOLZ, J. Gêneros orais e escritos na escola. Campinas: Mercado de Letras, p.7-18, 2004.

SHNEUWLY, B. Gêneros e tipos de discurso: considerações psicológicas e ontogenéticas. In: DOLZ, J.; SCHNEUWLY, B.; e colaboradores. Gêneros orais e escritos na escola. Tradução e organização de Roxane Rojo e Glaís Sales Cordeiro. Campinas, SP: Mercado de Letras, 2004.

SOARES, Magda. Linguagem e escala: uma perspectiva social. 17 col. São Paulo: Ática, 2002.

TEZZA, Cristóvão. Entre a prosa e a poesia: Bakhtin e o formalismo russo. Rio de Janeiro, Rocco, 2003.

VANDENBERG, L. Relatar emoções transforma as emoções relatadas? Um questionamento do paradigma de Pennebaker com implocações para a prevenção do transtorno do estresse pós-traumático. Ver Bras. De Ter. Comp. Cogn, 2004; 6 (1), 39-48.

VYGOTSKY, L. A formação social da mente. São Paulo: Martins Fontes, 1991.

WOODWARD, K. Identidade e diferença: uma introdução teórica e conceitual. In: SILVA, T. T. da; HAL, S.; WOODWARD, K. Identidade e diferença: a perspectiva dos estudos culturais. Petrópolis: Vozes, p. 07-72, 2000. 


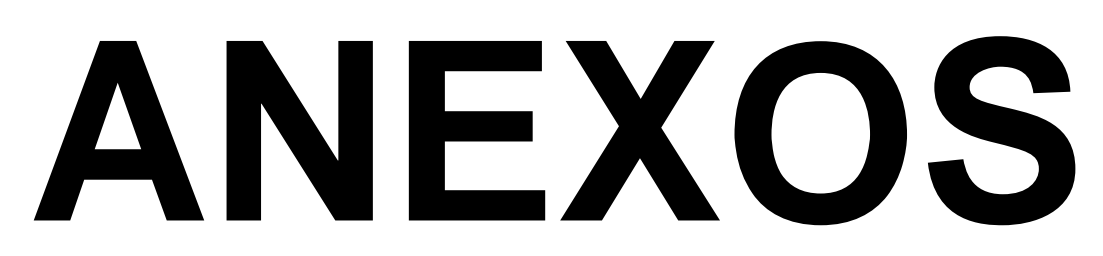

- Questionário

- Atividade de leitura (Atividade 1)

- Atividade de reescrita (Atividade 3)

- Produções Escritas 


\title{
QUESTIONÁRIO
}

\author{
UNIVERSIDADE DE SÃO PAULO \\ FACULDADE DE FILOSOFIA, LETRAS E CIÊNCIAS HUMANAS \\ DEPARTAMENTO DE LETRAS CLÁSSICAS E VERNÁCULAS \\ PROGRAMA DE PÓS-GRADUAÇÃO EM FILOLOGIA E LÍNGUA PORTUGUESA
}

Questionário desenvolvido por Carolina Fernandez Achutti, mestranda do Programa de Pós-Graduação em Filologia e Língua Portuguesa, para composição do corpus para a dissertação de mestrado $O$ ensino de autobiografia fundamental II: uma sequência didática, período de 2016-2018, sob a orientação da Prof. ${ }^{a}$ Dr. ${ }^{-}$Maria Inês Batista Campos.

\section{Colégio Anglo21}

Rua Comendador Elias Zarzur, 301, Alto da Boa Vista, São Paulo

Diretor: Harley Sato

\section{DADOS PESSOAIS DOS ALUNOS DO 7으은}

Nome:

Turma:

Idade:

Nacionalidade:

Bairro em que reside:

Escolaridade da Família

Pai:

Mãe:

Ensino fundamental II

Ensino médio

Ensino superior

Outros

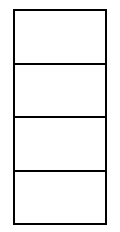

Ensino fundamental completo Ensino médio completo Ensino superior completo Outros

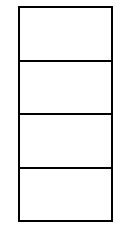

Quando você ouviu alguém Ihe contar uma história pela primeira vez? Conte como foi essa experiência. (5 LINHAS) 


\section{ATIVIDADE 1}

\section{Atividade de Leitura}

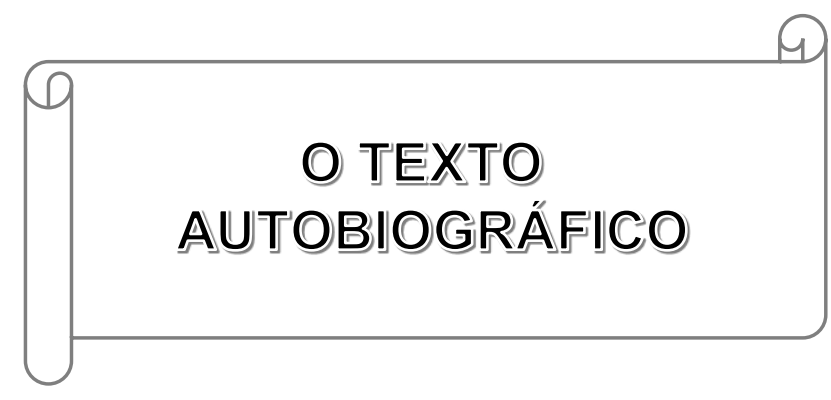

- Você gosta de ouvir histórias de vida?

- Quando você escuta essas histórias? Vamos conhecer a vida de quatro autores: Valéria Polizzi

Rinaldo Teixeira

James Carnac

José Lins do Rego

Valéria era uma jovem de 16 anos de idade que namorava um rapaz bem mais velho, de 25 anos, há dois anos. Sem muitas informações sobre as doenças sexualmente manteve relações sem preservativo e depois de algum tempo, descobre que está com AIDS.

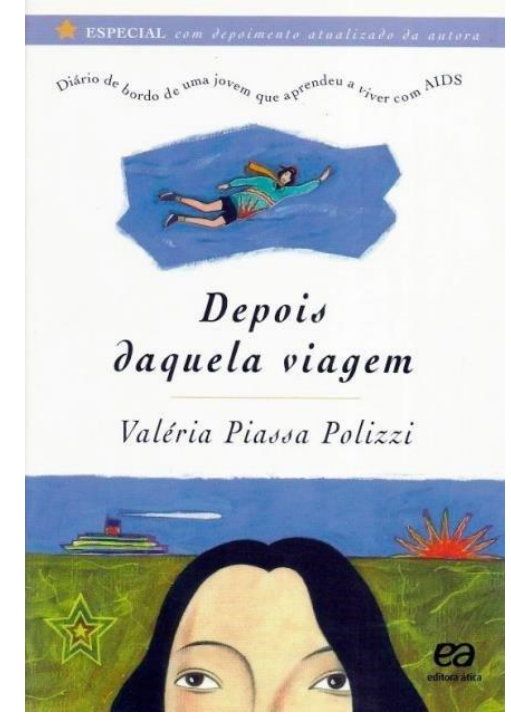

No Natal de 1986 eu tinha quinze anos e estava fazendo uma viagem de navio para a Argentina com meu pai e minha irmã, que é três anos mais nova do que eu. O navio era lindíssimo, cheio de salas, bares, restaurantes, cassino, piscina e show todas as noites. $O$ ambiente era estritamente familiar, muitas vovós, crianças, pais e mães, todo mundo passando o Natal junto, na maior calmaria. Piscina pela manhã, um jantar de gala à noite e, durante a tarde, uma volta pelas dependências do navio. E foi numa dessas, um belo dia, que eu vi um cara tropeçando. No auge dos meus quinze aninhos, não pude resistir e dei uma risadinha." (POLIZZI, Valéria Piassa. Depois daquela viagem, São Paulo: Ática, 1997, p.9)

Pronto. Não precisava dizer mais nada. Eu estava com AIDS. Aquele médico deve ter feito um teste sem meu consentimento e pior, deve ter ligado para o meu pai para dar o resultado. Que sacanagem, ele não tinha esse direito! Não consegui dizer uma palavra e também não me atrevi a olhar para o meu pai. Ficamos os dois em silêncio, olhando pela janela do carro. Eu pensando no susto que ele devia ter levado, ele pensando sabe Deus o quê." (POLIZZI, Valéria Piassa. Depois daquela viagem, São Paulo: Ática, 1997, p.27) 


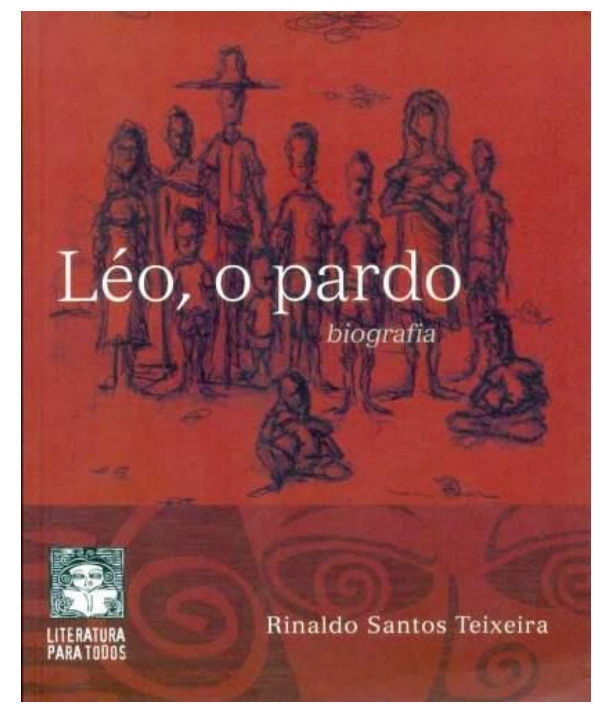

Rinaldo narra suas lembranças de sucessos e frustrações. Desde sua infância até a fase adulta. Trazendo algumas questões que marcaram a sua vida, como o preconceito por ser pardo e desfavorecido economicamente.

Dia desses, lembrei dos sonhos que tinha quando trabalhava com meu irmão, o Claudinei, na granja São Francisco, em Campo Belo, Minas Gerais. O dia todo cortando frangos: coxas, sobrecoxas, cabeças e pés de frango, e entrando naquela geladeira não sei quantos graus abaixo de zero, depois de comer uns pães de queijo, murchinhos, oferecidos pela Dona Celeste. De noite, eu deitava e sabia que estava pegando no sono quando os frangos, pelados, vinham dançar na minha cabeça, batendo as asinhas, rebolando. (TEIXEIRA, Rinaldo Santos. Léo, o pardo, Brasília: Literatura para todos,2006: p.13)

Então, tivemos alegrias e tristezas, mas aos dezesseis anos eu cheguei pra minha mãe e disse que queria muito morrer. E ela me olhou de modo seco. Minha mãe é realmente estranha, por exemplo, ela nunca chora, eu nunca vi a Dona Preta chorar. A tristeza dela se transforma em manchas roxas pelo corpo. Pra gente ela sempre aconselhava, "não chora tanto, menino, que lágrima é uma coisa que seca, quando a alma mais precisar dela, aí não desce mais". E nesse dia, eu tinha dezesseis anos e ela me disse: "se a vida não tem e nem te dá um propósito, então inventa, escolhe uma coisa que você gosta e briga por ela. Você gosta de livros por que então não vai ser professor?" Mas daí eu disse: "cinema", e ela respondeu: "que que tem o cinema?" E eu falei de novo, "eu vou fazer cinema". Ela ajeitou a fita métrica no pescoço, riscou o tecido de acordo com o molde que vinha fazendo e com firmeza passou a tesoura. "De filho de preto que eu já tive notícia que fez cinema foi só minha prima, que quando mudou pra São Paulo foi figurante do filme Ticotico no Fubá". E eu repeti: "cinema, vou fazer cinema”. E por causa disso eu fiquei vivo. Se eu consegui, depois vocês vão ficar sabendo. (TEIXEIRA, Rinaldo Santos. Léo, o pardo, Brasília: Literatura para todos,2006: p.24) 


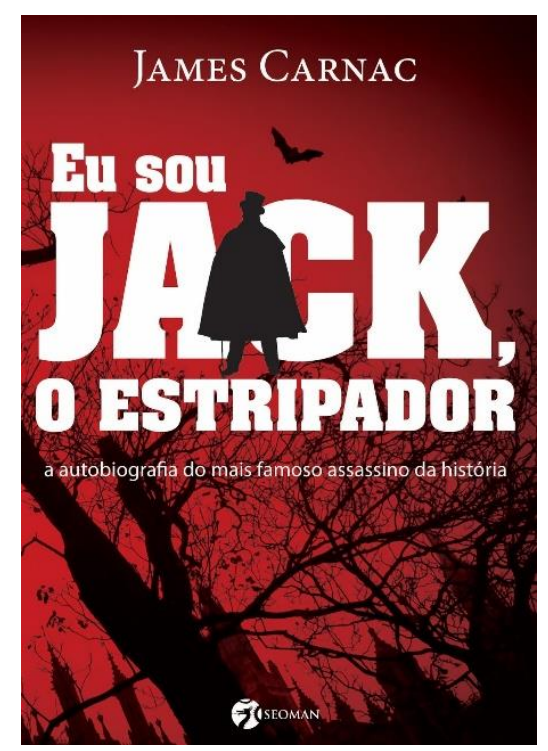

Em 1888, em Whitechapel, Londres, mulheres foram brutalmente assassinadas. O misterioso assassino, que ganhou a alcunha de Jack, o estripador, tornou-se mundialmente conhecido e nunca foi identificado ou preso pelos crimes. Contudo, por volta de 1930 entre os pertences de um homem, um texto autobiográfico é encontrado. Em primeira pessoa, Jack narra sua trajetória desde a infância, trazendo motivações e algumas descrições sobre os crimes.

Posso tocar apenas de passagem esses anos primordiais, pois a memória deles é intermitente, e os incidentes triviais que sou capaz de lembrar pouco me interessam. Vou pular o período dos meus primeiros anos escolares no que deve ter sido, creio eu, uma escola da igreja ou na casa de uma professora, e tentar descrever minha primeira escola de garoto para a qual fui enviado com aproximadamente doze anos. (CARNAC, James. Eu sou Jack, o estripador: a autobiografia do mais famoso assassino da história, tradução de Jorge Ritter, São Paulo: Seoman,2016: p.3)

Acho que foi o fascínio em relação a facas que consolidou minha decisão de adotar a profissão do meu pai. Eu não tinha desejo algum de tratar caxumba ou sarampos, tampouco, admitirei, qualquer desejo de aliviar o sofrimento humano. Mas eu queria dissecar. Eu queria cortar carne, não a carne cozida, mas a carne humana. Quão demoníaco isso deve parecer[...]. (CARNAC, James. Eu sou Jack, o estripador: a autobiografia do mais famoso assassino da história, tradução de Jorge Ritter, São Paulo: Seoman,2016: p.93) 


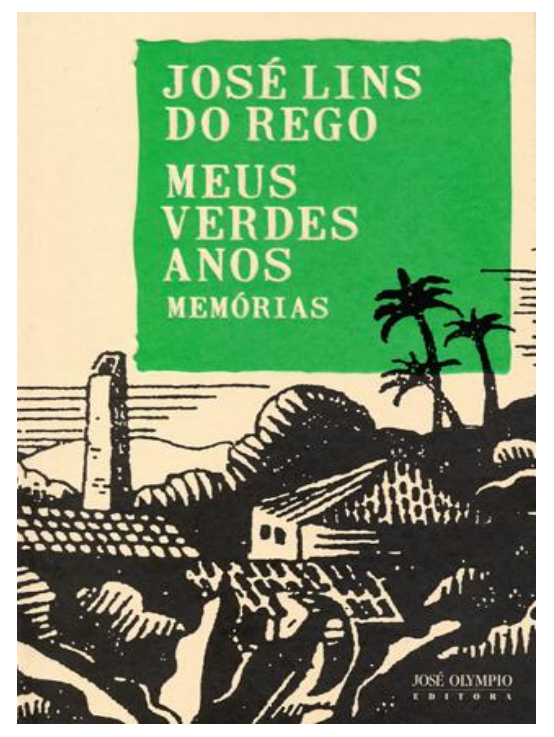

José Lins do Rego narra suas primeiras lembranças, fala de sua sofrida infância no engenho do avô, abordando temas como divisão de classes, preconceito racial e, até, sobre a descoberta da sexualidade.

[...]é preciso confessar: não gostava de minha avó. Aversão gratuita, pois ela nunca levantou a mão contra mim. E me sentia mal a seu lado. Era uma figura sombria, guardava preferências absurdas, não era amada pelas negras da cozinha. O vício do rapé dava-Ihe uma cor esquisita ao nariz. E como não enxergava bem, ficava sentada o dia todo numa cadeira de balanço a dormitar. (REGO, José Lins. Meus Verdes Anos, Rio de Janeiro, José Olympio, [1956] gaed, 2011:p.22)

Sempre de manhã a minha tia me acordava para tomar leite ao pé da vaca. Nas manhãs de sol o curral dos animais de manjedoura se enchia de trabalho. Os moleques curavam as bicheiras, lavavam os bezerros novos e o mestre Amâncio tirava leite. Se chovia, tudo se transformava em lama que atolava até as canelas. Vinham meninos das redondezas atrás do leite que o meu avô dava aos pobres. Esguichava na cuia branca o leite das turinas. Ainda não havia aparecido as febres no gado. Tudo era são. Vacas que davam cuias e cuias de leite. Conhecíamos todas pelos nomes: Mocinha, Malhada, Estrela Nova, Cotovia. (REGO, José Lins. Meus Verdes Anos, Rio de Janeiro, José Olympio, [1956] gaed, 2011: p.33)

Uma vez mandaram dizer a tia Naninha que eu ficava para jantar. E ela não permitiu. E foi áspera quando eu cheguei. Só imaginar a cara do marido chegando na mesa com as suas histórias fazia-me infeliz. Caí no pranto com a reprimenda da tia. E ela, que nunca me batia a sério, veio furiosa em cima de mim, de chinela, como se eu fosse Virgínia. Deixou-me o corpo marcado. (REGO, José Lins. Meus Verdes Anos, Rio de Janeiro, José Olympio, [1956]

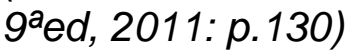


Observe nos trechos lidos, como a $1^{\underline{a}}$ pessoa marca o ponto de vista do narrador, isto é, como se apresenta o subjetivo.

Note como aparecem os pronomes pessoais do caso reto e do caso oblíquo.

Vamos recordar?

Pronomes:

\begin{tabular}{|c|c|c|c|}
\hline Número & Pessoa & $\begin{array}{c}\text { Pronome pessoal do } \\
\text { caso reto }\end{array}$ & $\begin{array}{c}\text { Pronomes pessoais do } \\
\text { caso oblíquo }\end{array}$ \\
\hline Singular & Primeira & $\mathrm{Eu}$ & $\mathrm{Me}, \mathrm{mim}$, comigo \\
\hline
\end{tabular}

Marcas de temporalidade:

Advérbios: hoje, amanhã, depois, ainda, de repente, etc.

Conjunções: enquanto isso, depois disso, logo que, assim que, etc.

Preposições: até, após, desde, etc.

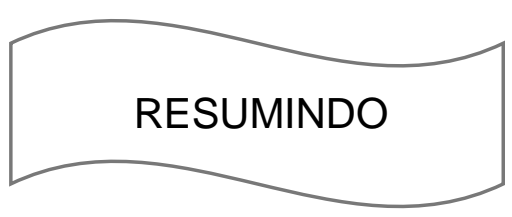

Então, uma autobiografia deve apresentar:

a) a forma da linguagem narrativa, em prosa;

b) o assunto tratado diz respeito à vida individual;

c) a identidade do autor, devendo ser uma pessoa real (e não um personagem ficcional);

d) coincidência entre a identidade do narrador e a do personagem principal;

e) deve possuir uma perspectiva retrospectiva, deve falar do passado. 


\title{
Atividade 3
}

\section{Atividade de reescrita}

\author{
UNIVERSIDADE DE SÃO PAULO \\ Programa de Pós-Graduação em Filologia e Língua Portuguesa \\ OUTUBRO DE 2017
}

\begin{abstract}
Atividade escolar proposta pela professora Carolina Fernandez Achutti como parte de sua dissertação de mestrado no PPG Filologia e Língua Portuguesa.
\end{abstract}

NOME:

TURMA:

NOME DO LEITOR:

DATA:

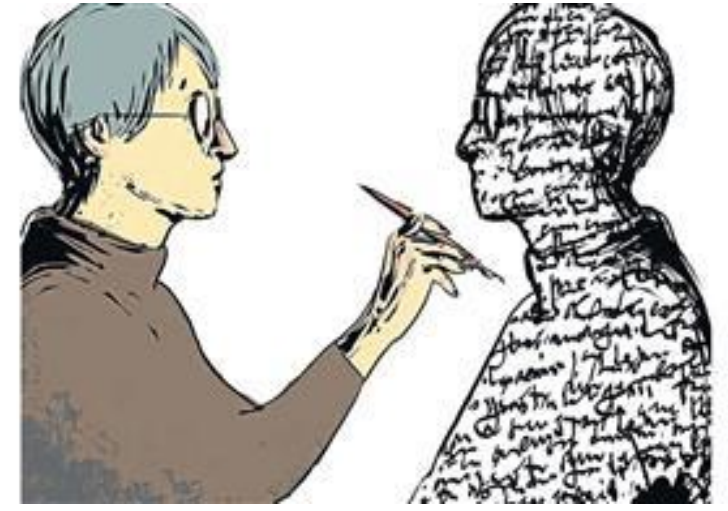

Você se recorda da atividade que fizemos sobre autobiografias no primeiro semestre? As leituras e a sua produção?

A autobiografia é um texto escrito pelo próprio autor, que não precisa seguir uma estrutura e a sua finalidade é contar a sua própria vida tendo como interlocutor o público em geral. Geralmente, na autobiografia, o autor traz dados pessoais, ou seja, verídicos e os verbos são empregados no passado.

Esta atividade está organizada em duas etapas:

\section{Etapa 1}

Reúna-se com seu colega para que cada um possa se tornar leitor crítico do texto do outro. Nessa releitura, observe se o autor considerou a presença de um interlocutor e realizou a seleção de dados importantes da vida pessoal. O que mais você gostaria de saber sobre a trajetória de seu amigo? Ajude-o a construir a melhor autobiografia possível.

\section{Etapa 3}

Em seguida, façam as alterações que julgarem necessárias reescrevendo os próprios textos e passem a limpo. 
Texto 1

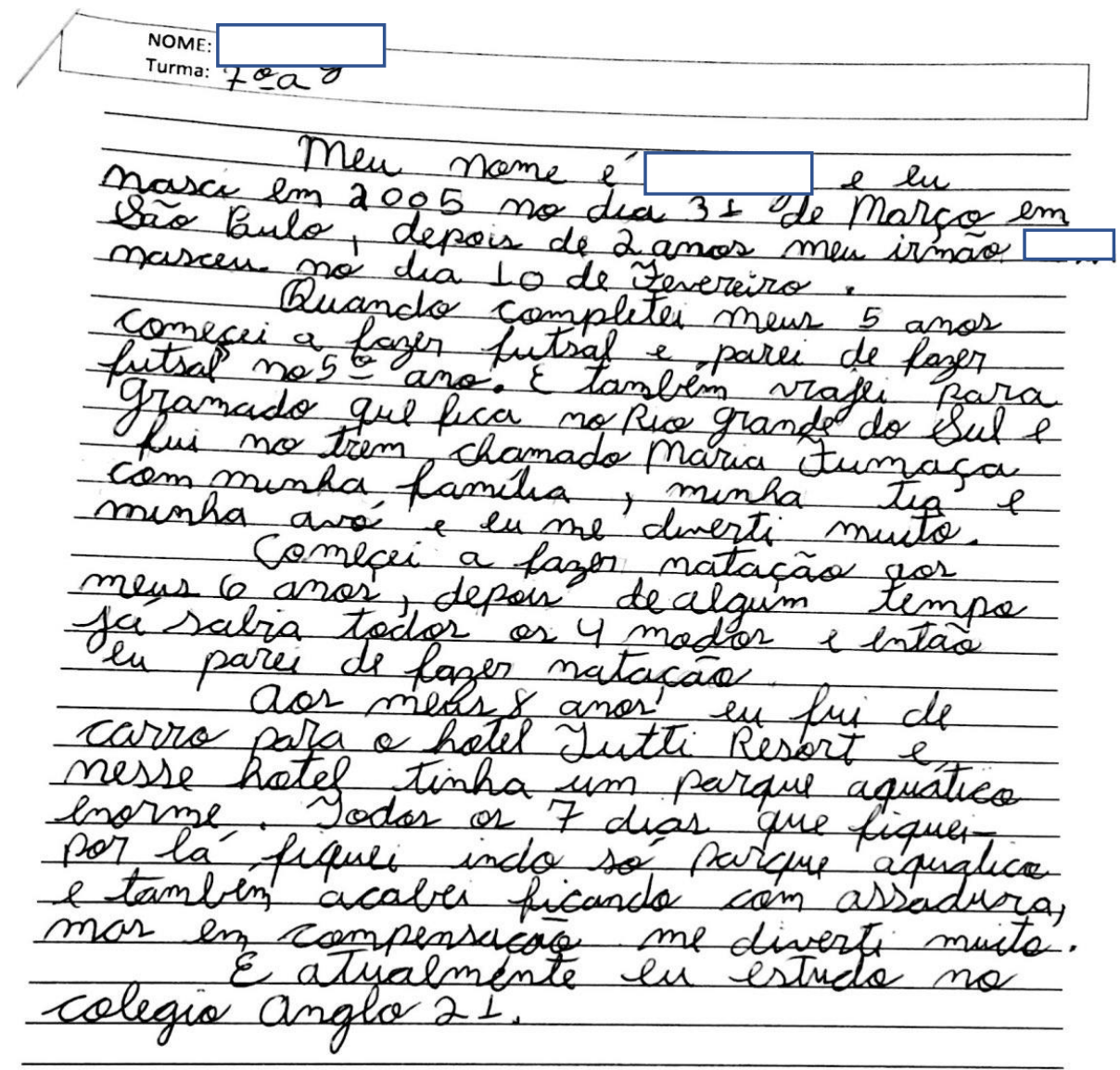

Meu nome é A. e eu nasci em 2005 no dia 31 de Março em São Paulo, depois de 2 anos meu irmão R. nasceu no dia 10 de Fevereiro.

Quando completei meus 5 anos comecei a fazer futsal e parei de fazer futsal no $5^{\circ}$ ano. E também viajei para Gramado que fica no Rio Grande do Sul e fui no trem chamado Maria Fumaça com minha família, minha tia e minha avó e eu me diverti muito.

Comecei a fazer natação aos meus 6 anos, depois de algum tempo já sabia os 4 modos e então eu parei de fazer natação.

Aos meus 8 anos eu fui de carro para o hotel Tutti Resort e nesse hotel tinha um parque aquático enorme. Todos os 7 dias que fiquei por lá fiquei indo só parque aquatico e também acabei ficando com assadura, mas em compensação me diverti muito.

E atualmente eu estudo no colegio Anglo 21. 
Texto 2

MINHA AUTO-BIOGRAFIA

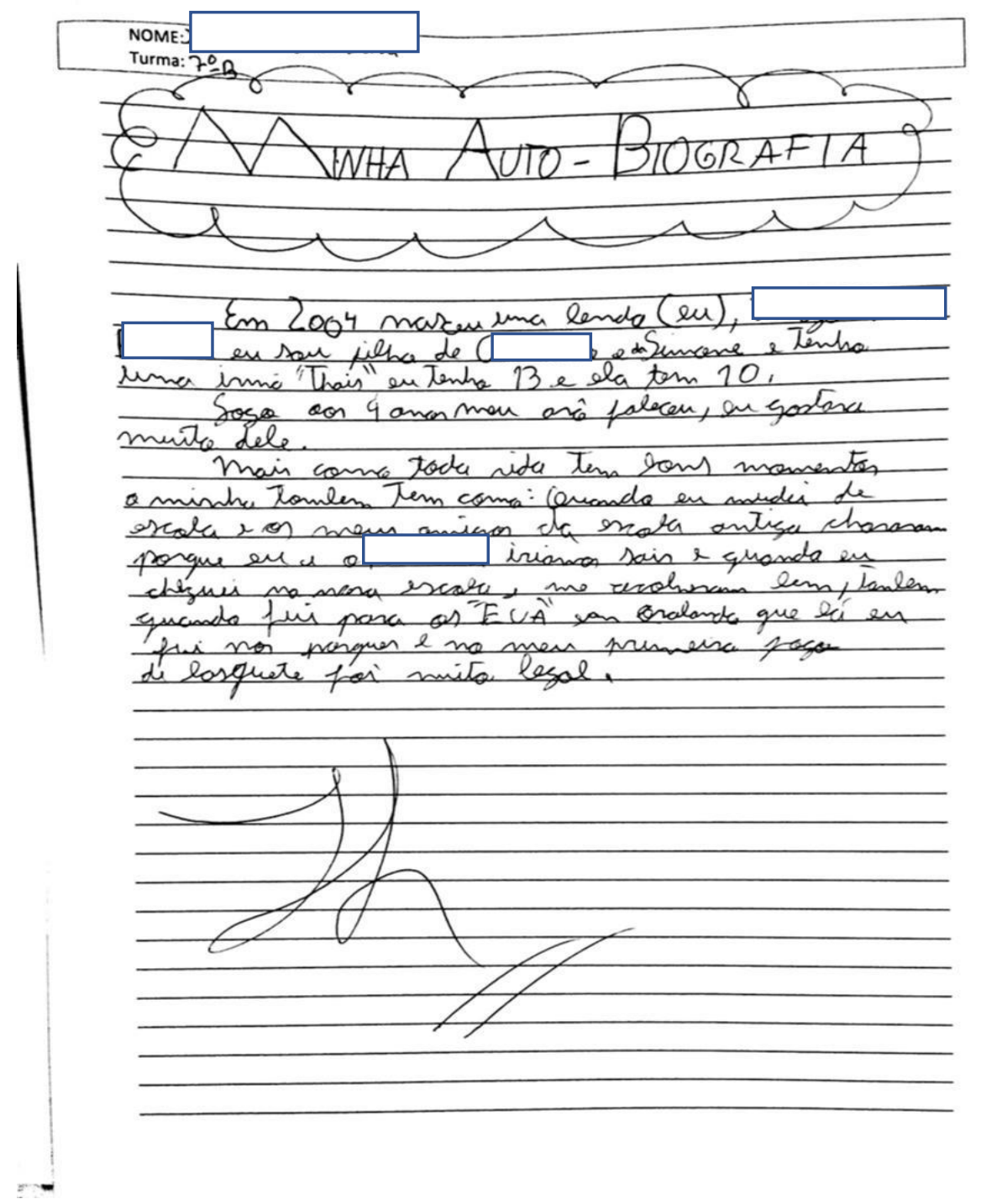

Em 2004 nasceu uma lenda (eu), T. R. P. eu sou filho de A. e da S. e tenho uma irmã "T." eu tenho 13 e ela tem 10.

Logo aos 4 anos meu avô faleceu, eu gostava muito dele.

Mais como toda vida tem bons momentos a minha tambem tem como: quando eu mudei de escola e os meus amigos da escola antiga choraram porque eu e o P. iriamos sair e quando eu cheguei na nova escola, me acolheram bem, tambem quando fui para os "EUA" em Orlando que lá eu fui nos parques e no meu primeiro jogo de basquete foi muito legal.

$\mathrm{TH}$ 
Texto 3

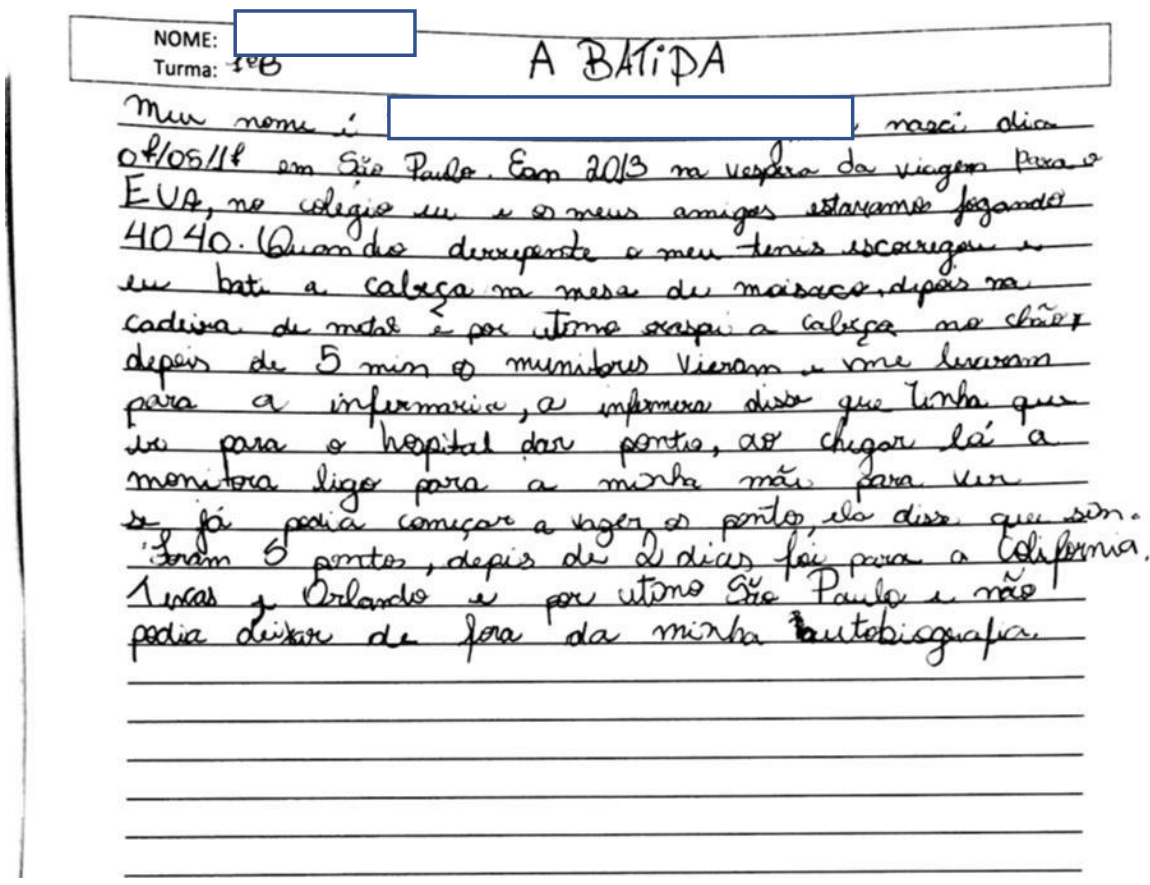

\section{A BATIDA}

Meu nome é R. R. K. Ignacio nasci dia 07/05/17 em São Paulo. Em 20/3 na vespera da viagem para o EUA, no colégio eu e os meus amigos estavamos jogando 4040. Quando derrepente o meu tenis escorregou e eu bati a cabeça na mesa de moisaco, depois na cadeira de metal e por utimo raspei a cabeça no chão, depois de 5 min os munitores Vieram e me levaram para a infermaria, a infermera disse que Tinha que ir para o hospital dar ponto, ao chegar lá a monitora ligo para minha mãe para ver se já podia começar a fazer os pontos, ela disse que sim.

Foram 5 pontos, depois de 2 dias foi para a California, Texas e Orlando e por utimo São Paulo e não podia deixar de fora da minha autobiografia. 
Texto 4

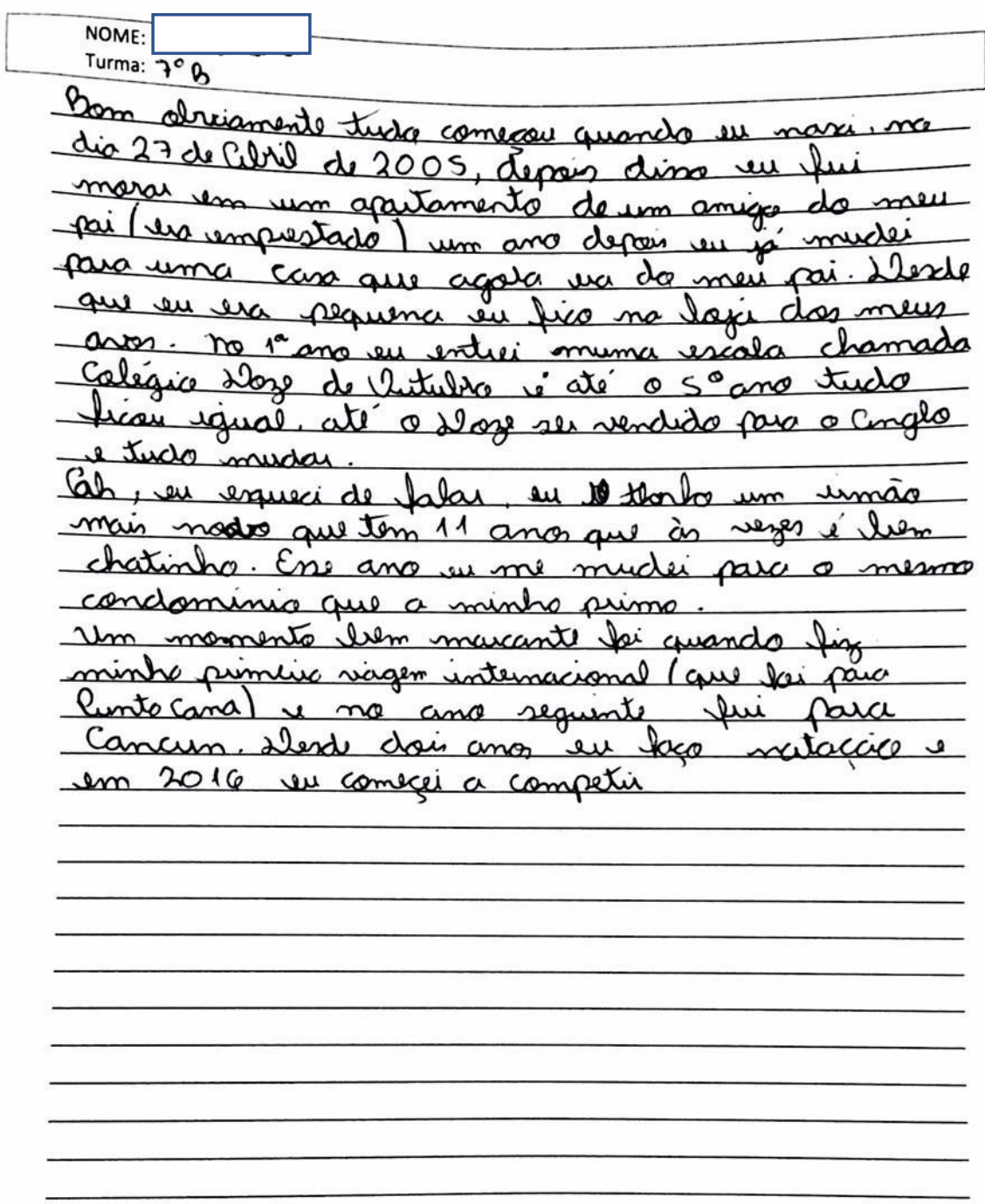

Bom obviamente tudo começou quando eu nasci, no dia 27 de Abril de 2005, depois disso eu fui morar em um apartamento de um amigo do meu pai (era emprestado) um ano depois eu já mudei para uma casa que agora era do meu pai. Desde que eu era pequena eu fico na loja dos meus avos. No $1^{\circ}$ ano eu entrei numa escola chamada Colégio Doze de Outubro e até o $5^{\circ}$ ano tudo fivou igual, até o Dozer ser vendido para o Anglo e tudo mudar.

Ah, eu esqueci de falar, eu tenho um irmão mais novo que tem 11 anos que às vezes é bem chatinho. Esse ano eu me mudei para o mesmo condominio que a minha prima.

Um momento bem marcante foi quando fiz minha primeira viagem internacional (que foi para Punta Cana) e no ano seguinte fui para Cancun. Desde dois anos eu faço natação e em 2016 eu comecei a competir 
Texto 5

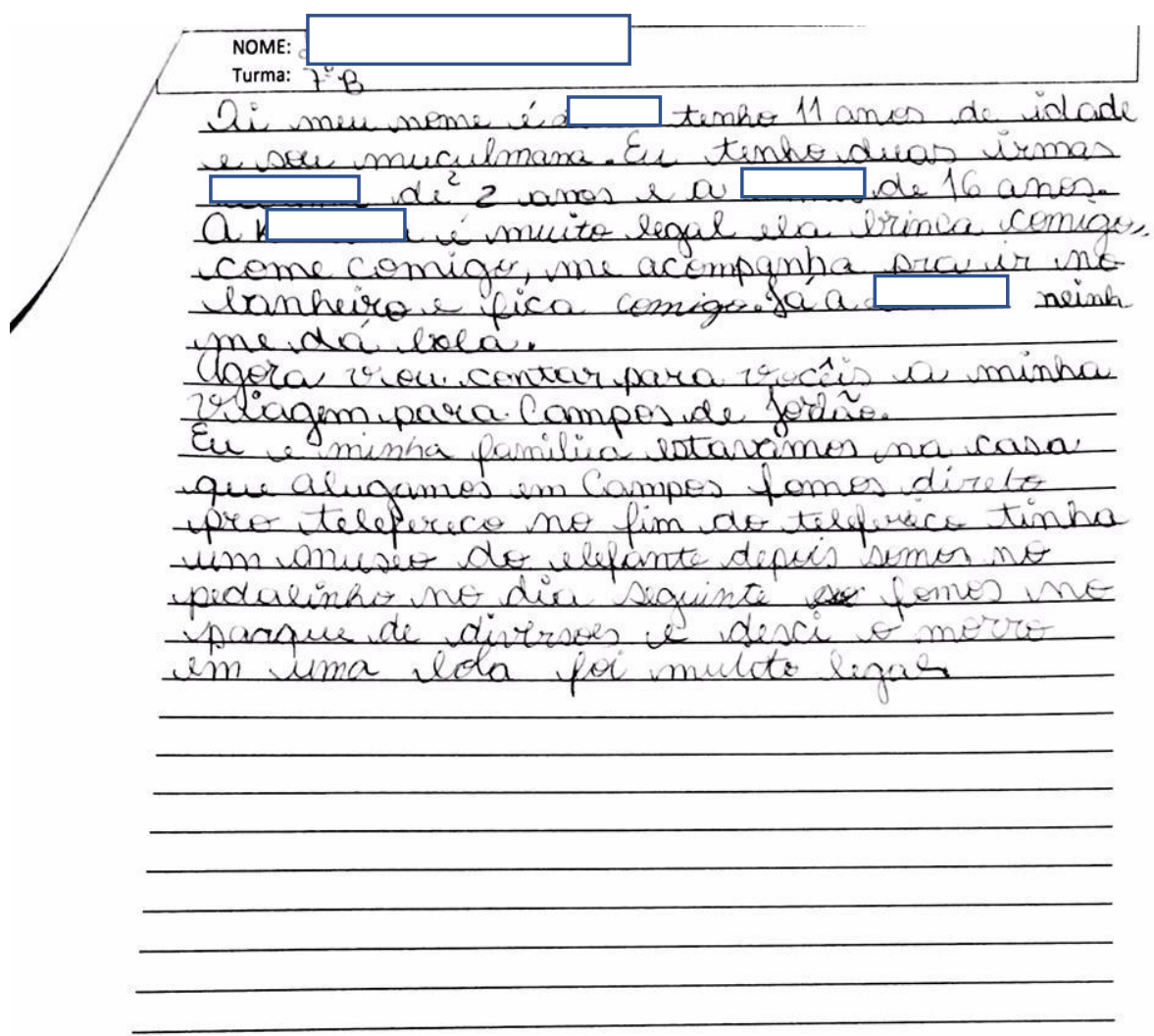

Oi meu nome é $L$ tenho 11 anos de idade e sou muçulmana. Eu tenho duas irmas $\mathrm{K}$. de 2 anos e a L. de 16 anos. A K. é muito legal ela brinca comigo, come comigo, me acompanha pra ir no banheiro e fica comigo. Já a L. neinha dá bola.

Agora vou contar para vocêis a minha viagem para Campos de Jordão.

Eu e minha familia estavamos na casa que alugamos em Campos fomos direto pro teleferico no fim do teleferico tinha um anuseo do elefante depois somos no pedalinho no dia seguinte fomos no parque de diversoes e desci o morro em uma bola foi muito legal 
Texto 6

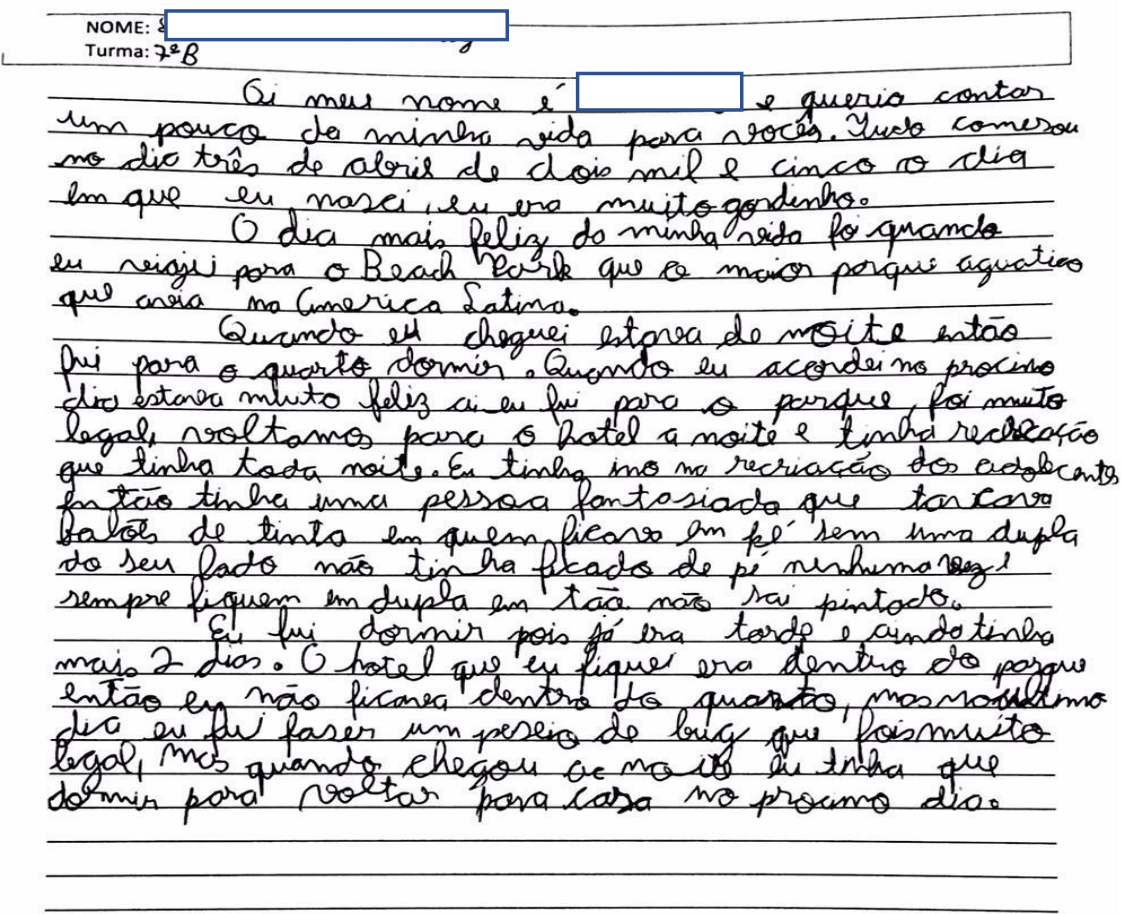

Oi meu nome é L. e queria contar um pouco da minha vida para vocês. Tudo comesou no dia três de abril de dois mil e cinco o dia em que eu nasci, eu era muito gordinho.

O dia mais feliz da minha vida foi quando eu viajei para o Beach Park que o maior parque aquatico que avia na America Latina.

Quando eu cheguei estava de noite então fui para o quarto dormir. Quando eu acordei no procimo dia estava muito feliz ai fui para o parque, foi muito legal, voltamos para o hotel a noite e tinha recreação que tinha toda noite. Eu tinha isso na recriação dos adolecentes então tinha uma pessoa fantasiada que tacava balões de tinta em que ficava em pé sem uma dupla do seu lado não tinha ficado de pé nenhuma vez e sempre fiquem em dupla em tão não sai pintado.

Eu fui dormir pois já era tarde e ainda tinha mais 2 dias. O hotel que eu fiquei era dentro do parque então eu não ficava dentro do quarto, mas no ultimo dia eu fui faser um paseio de bug que fois muito legal, mas quando chegou de noite eu tinha que dormir para voltar para casa no procimo dia. 
Texto 7

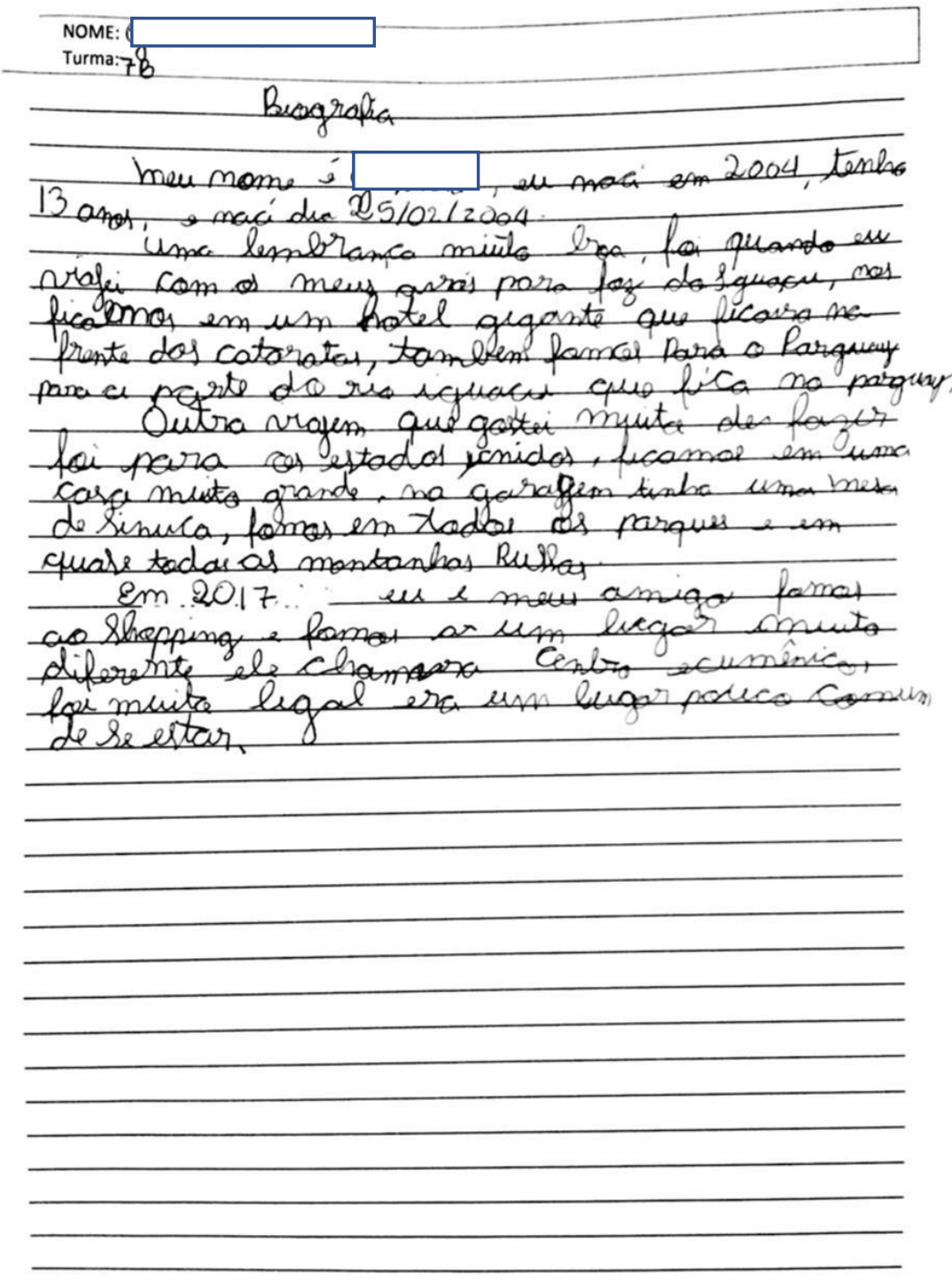

Meu nome é G. , eu naci em 2004, tenho 13 anos, e naci dia 25/02/2004.

Uma lembrança muito boa, foi quando eu viajei com os meus avós para foz do Iguaçu, nos ficamos em um hotel gigante que ficava na frente das cataratas, tambem fomos para o Paraguay para a parte do rio iguaçu que fica no paraguay,

Outra viagem que gostei muito de fazer foi para os estados unidos, ficamos em uma casa muito grande, na garagem tinha uma mesa de sinuca, fomos em todos os parques e em quase todas as montanhas Russas.

Em 2017 eu e meu amigo fomos ao shopping e fomos a um lugar muito diferente ele chamava Centro ecumênico, foi muito legal era um lugar pouco comum de se estar. 
Texto 8

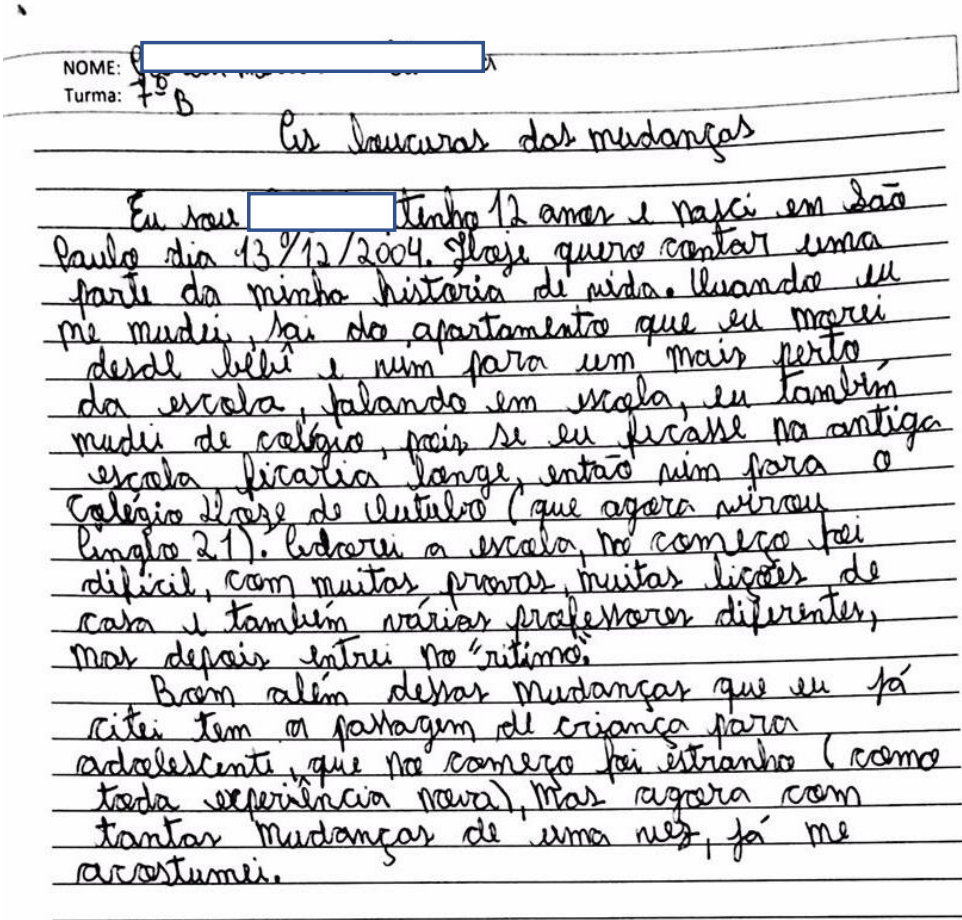

As loucuras das mudanças

Eu sou G., tenho 12 anos e nasci em São Paulo dia 13/12/2004. Hoje quero contar uma parte da minha história de vida. Quando eu me mudei, sai do apartamento que eu morei desde bebê e vim para um mais perto da escola, falando em escola, eu também mudei de colégio, pois se eu ficasse na antiga escola, ficaria longe, então vim para o Colégio Doze de Outubro (que agora virou Anglo 21). Adorei a escola, no começo foi difícil, com muitas provas, muitas lições de casa e também vários professores diferentes, mas depois entrei no "ritimo".

Bom além dessas mudanças que eu já citei tem a passagem de criança para adolescente, que no começo foi estranho (como toda experiência nova), mas agora com tantas mudanças de uma vez, já me acostumei. 
Texto 9

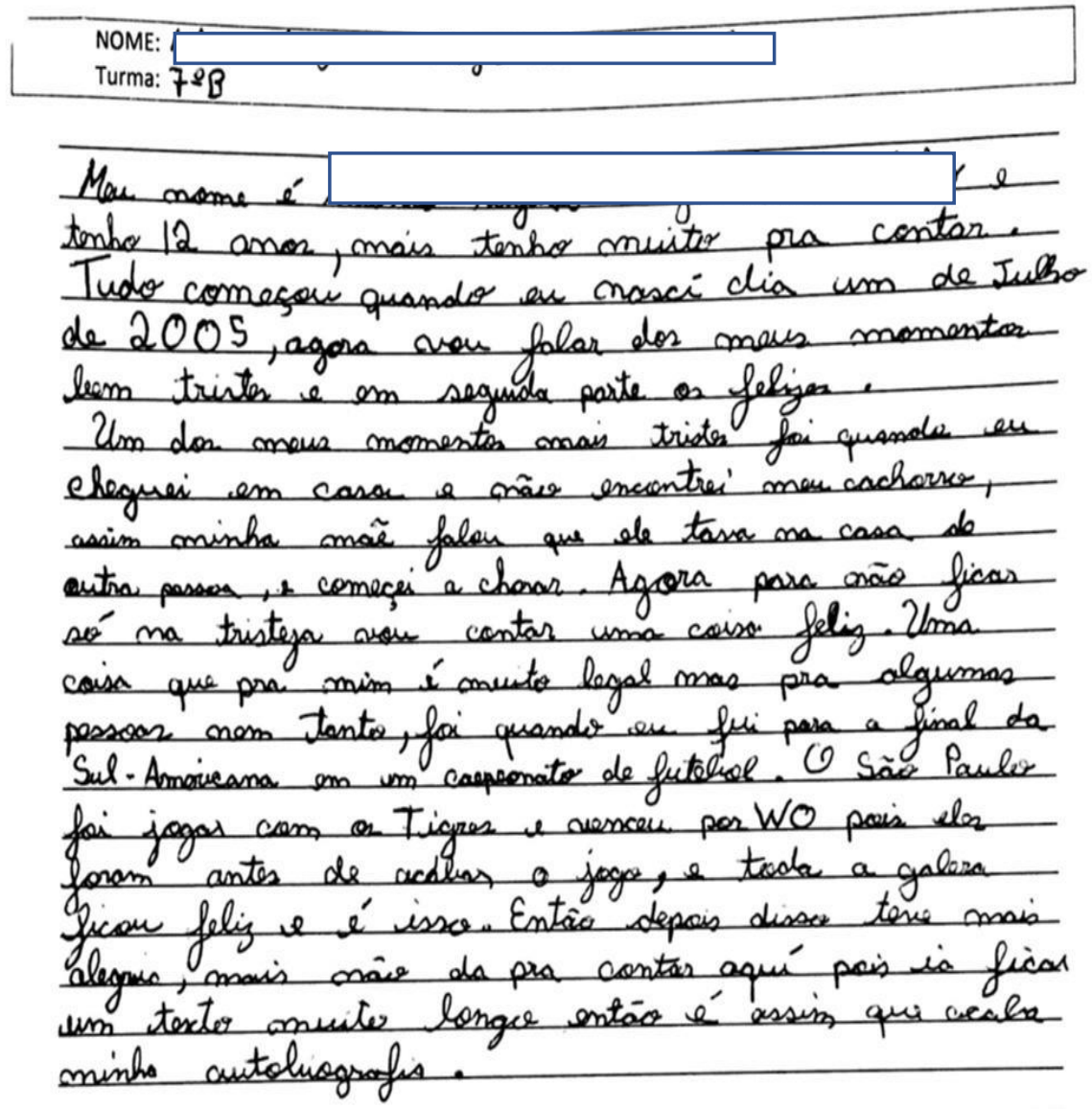

Meu nome é A. A. C. A. L. e tenho 12 anos, mais tenho muito pra contar.

Tudo começou quando eu nascí dia um de Julho de 2005, agora vou falar dos meus momentos bem tristes e em segunda parte os felizes.

Um dos meus momentos mais tristes foi quando eu cheguei em casa e não encontrei meu cachorro, assim minha mãe falou que ele tava na casa de outra pessoa, e começei a chorar. Agora para não ficar só na tristeza vou contar uma coisa feliz. Uma coisa que pra mim é muito legal mas pra algumas pessoas nem tanto , foi quando eu fui para o final da Sul-Americana em um campeonato de futebol. O São Paulo foi jogar com os Tigres e venceu por WO pois eles foram antes de acabar o jogo, e toda a galera ficou feliz e é isso. Então depois disso teve mais alegria, mais não da pra contar aquí pois ia ficar um texto muito longo então é assim que acaba a minha autobiografia. 
Texto 10

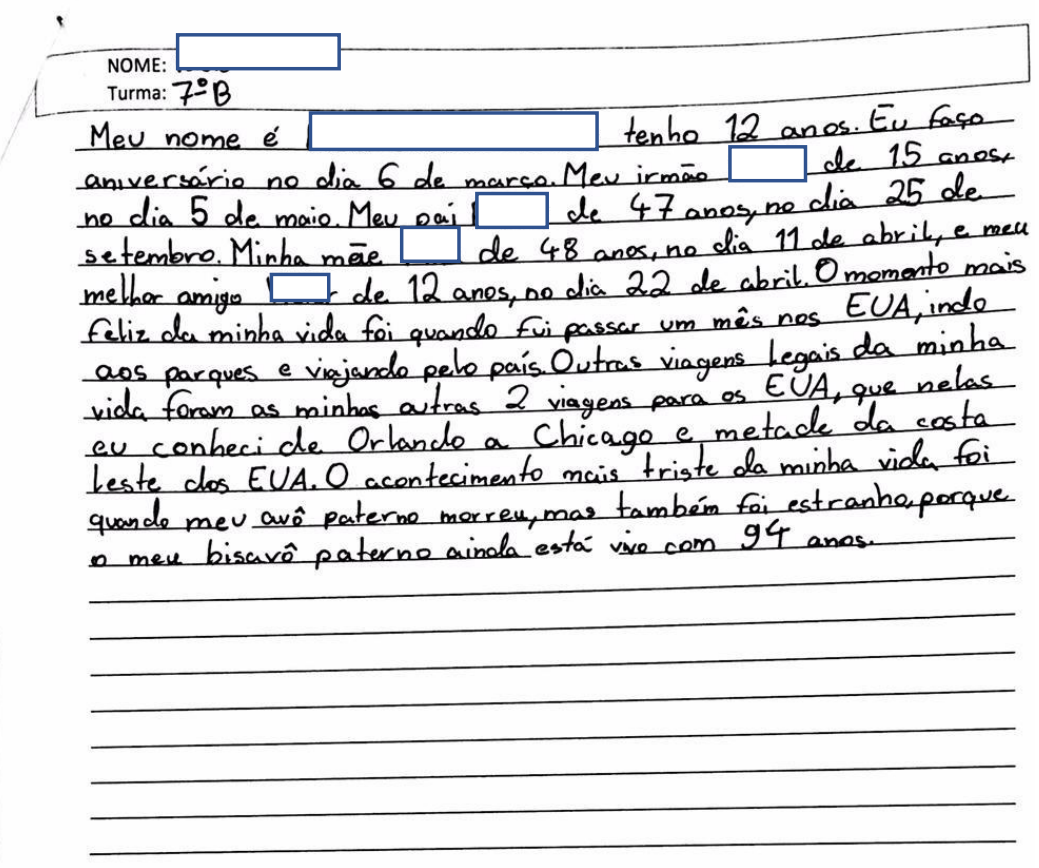

Meu nome é F. R. X. tenho 12 anos. Eu faço aniversário no dia 6 de março. Meu irmão P. de 15 anos, no dia 5 de maio. Meu pai P. de 47 anos, no dia 25 de setembro. Minha mãe M. de 48 anos, no dia 11 de abril, e meu melhor amigo V. de 12 anos, no dia 22 de abril. O momento mais feliz da minha vida foi quando eu fui passar um mês nos EUA, indo aos parques e viajando pelo país. Outras viagens legais da minha vida foram as minhas outras 2 viagens para os EUA, que nelas eu conheci de Orlando a Chicago e metade da costa Leste dos EUA. $\mathrm{O}$ acontecimento mais triste da minha vida foi quando meu avô paterno morreu, mas também foi estranho, porque o meu bisavô paterno ainda está vivo com 94 anos. 


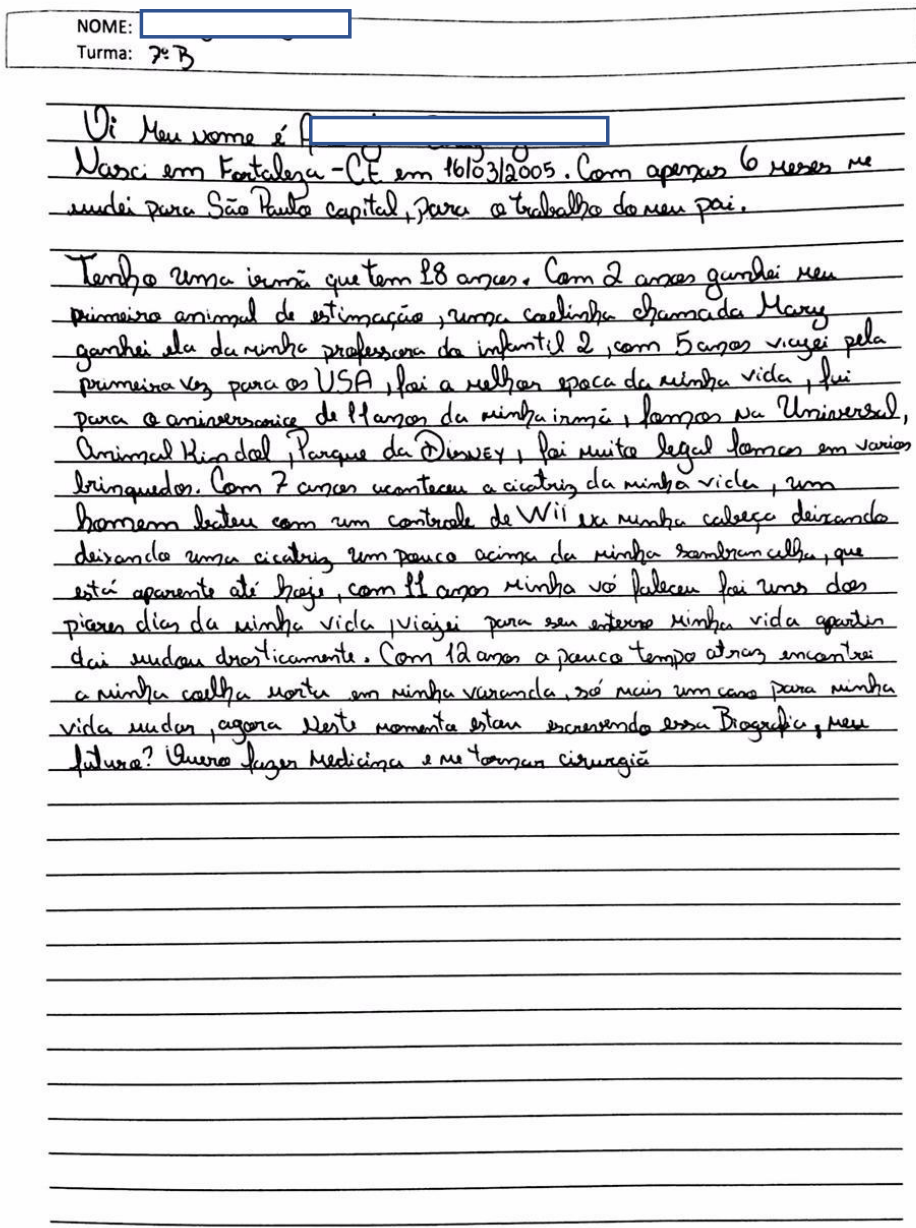

Oi Meu nome é A. J. B. J..

Nasci em Fortaleza-CE em 16/03/2005. Com apenas 6 meses me mudei para São Paulo capital, para o trabalho do meu pai.

Tenho uma irmã que tem 18 anos. Com 2 anos ganhei meu primeiro animal de estimação, uma caelinha chamada Mary ganhei ela da minha professora do infantil 2, com 5 anos viajei pela primeira vez para os USA, foi a melhor epoca da minha vida, fui para o aniversario de 11 anos da minha irmã, fomos na Universal, Animal Kindol, Parque da Disney, foi muito legal fomos em varios brinquedos. Com 7 anos aconteceu a cicatriz da minha vida, um homem bateu com o controle de WII na minha cabeça deixando uma cicatriz um pouco acima da minha sombrancelha, que está aparente até hoje, com 11 anos minha vó faleceu foi uns dos piores dias da minha vida, viajei para seu enterro minha vida apartir dai mudou drasticamente. Com 12 anos a pouco tempo atraz encontrei a minha coelha morta em minha varanda, só mais um caso para minha vida mudar, agora Neste momento estou escrevendo essa Biografia, meu futuro? Quero fazer Medicina e me tornar cirurgiã 
Texto 12

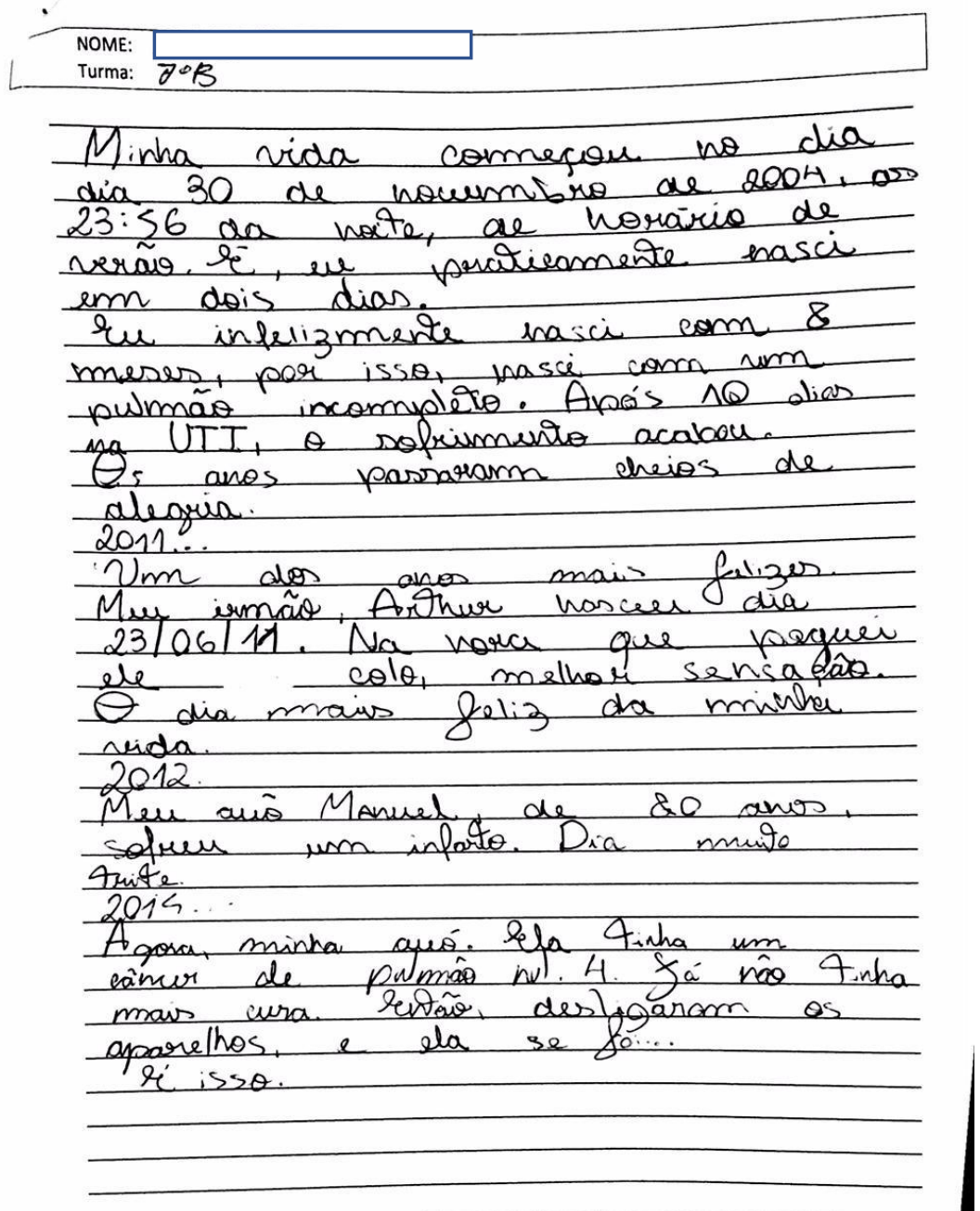

Minha vida começou no dia dia 30 de novembro de 2004, as 23:56 da noite, de horário de verão. É, eu praticamente nasci em dois dias.

Eu infelizmente nasci com 8 meses, por isso, nasci com um pulmão incompleto. Após 10 dias na UTI, o sofrimento acabou.

Os anos passaram cheios de alegria.

$2011 \ldots$

Um dos anos mais felizes.

Meu irmão, Arthur nasceu dia 23/06/11. Na hora que peguei ele colo, melhor sensação.

O dia mais feliz da minha vida.

2012.

Meu avô Manuel, de 80 anos, sofreu um infarto. Dia muito triste.

2014...

Agora, minha avó. Ela tinha um câncer de pulmão nu. 4. Já não tinha mais cura. Então, desligaram os aparelhos, e ela se foi....

É isso. 
Texto 13

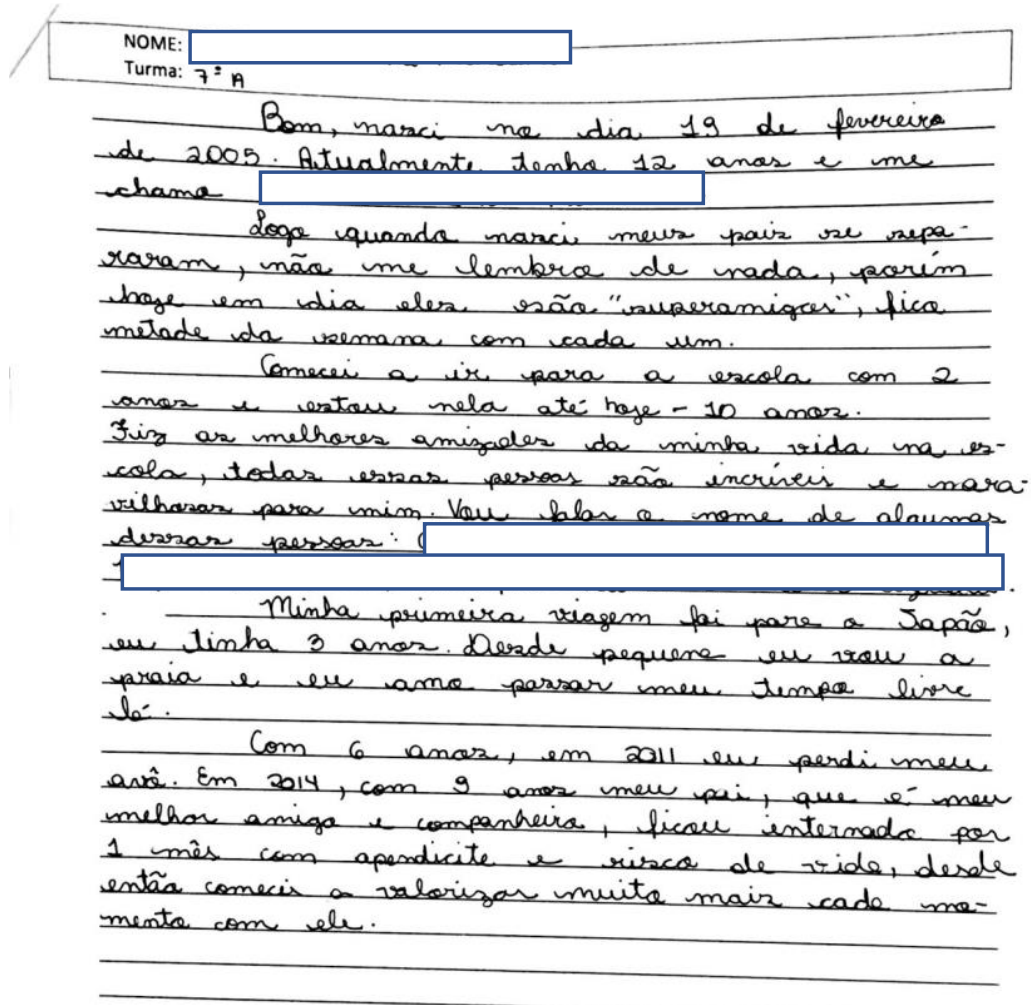

Bom, nasci no dia 19 de fevereiro de 2005. Atualmente tenho 12 anos e me chamo A. C. A. M.

Logo quando nasci meus pais se separaram, não me lembro de nada, porém hoje em dia eles são "superamigos", fico metade da semana com cada um.

Comecei a ir para a escola com 2 anos e estou nela até hoje - 10 anos.

Fiz as melhores amizades da minha vida na escola, todas essas pessoas são incríveis e maravilhosas para mim. Vou falar o nome de algumas dessas pessoas: G. L., B. G., R. S., H. K. e L. A.

Minha primeira viagem foi para o Japão, eu tinha 3 anos. Desde pequena eu vou a praia e amo passar meu tempo livre lá.

Com 6 anos, em 2011 eu perdi meu avô. Em 2014, com nove anos emu pai, que é meu melhor amigo e companheiro, ficou internado por 1 mês com apendicite e risco de vida, desde então comecei a valorizar mais cada momento com ele. 
Texto 14

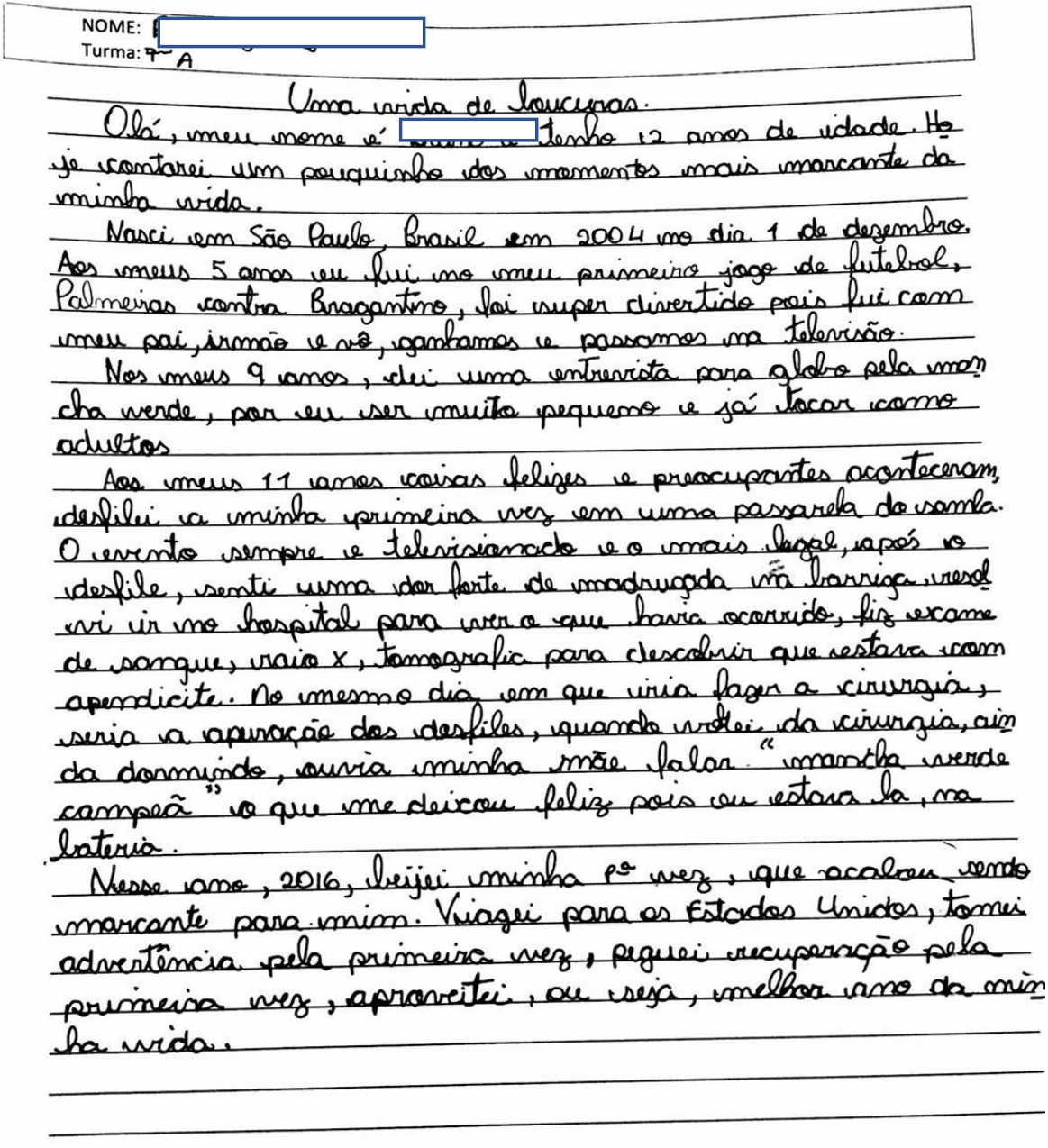

Uma vida de loucuras.

Olá, meu nome é B. e tenho 12 anos de idade. Hoje contarei um pouquinho dos momentos mais marcantes da minha vida.

Nasci em São Paulo, Brasil em 2004 no dia 1 de dezembro. Aos meus 5 anos eu fui no meu primeiro jogo de futebol. Palmeiras contra Bragantino, foi super divertido pois fui com meu pai, irmão e vô, ganhamos e passamos na televisão.

Nos meus 9 anos, dei uma entrevista para globo pela mancha verde, por eu ser muito pequeno e jpa tocar como adultos

Aos meus 11 anos coisas felizes e preocupantes aconteceram, desfilei a minha primeira vez em uma passarela do samba.O evento sempre e televisionado e o mais legal, após o desfile, senti uma dor forte de madrugada na barriga, resolvi ir no hospital para ver o que havia ocorrido, fiz exame de sangue, raio $x$, tomografia para descobrir que estava com apendicite. No mesmo dia em que iria fazer a cirurgia, seria a apuração dos desfiles, quando voltei da cirurgia, ainda dormindo, ouvi minha mãe falar "mancha verde campeã" o que me deixou feliz pois eu estava la, na bateria. 
Nesse ano, 2016, beijei minha primeira vez, que acabou sendo marcante para mim. Viagei para os Estados Unidos, tomei advertência pela primeira vez, peguei recuperação pela primeira vez, aproveitei, ou seja, melhor ano da minha vida. 
Texto 15

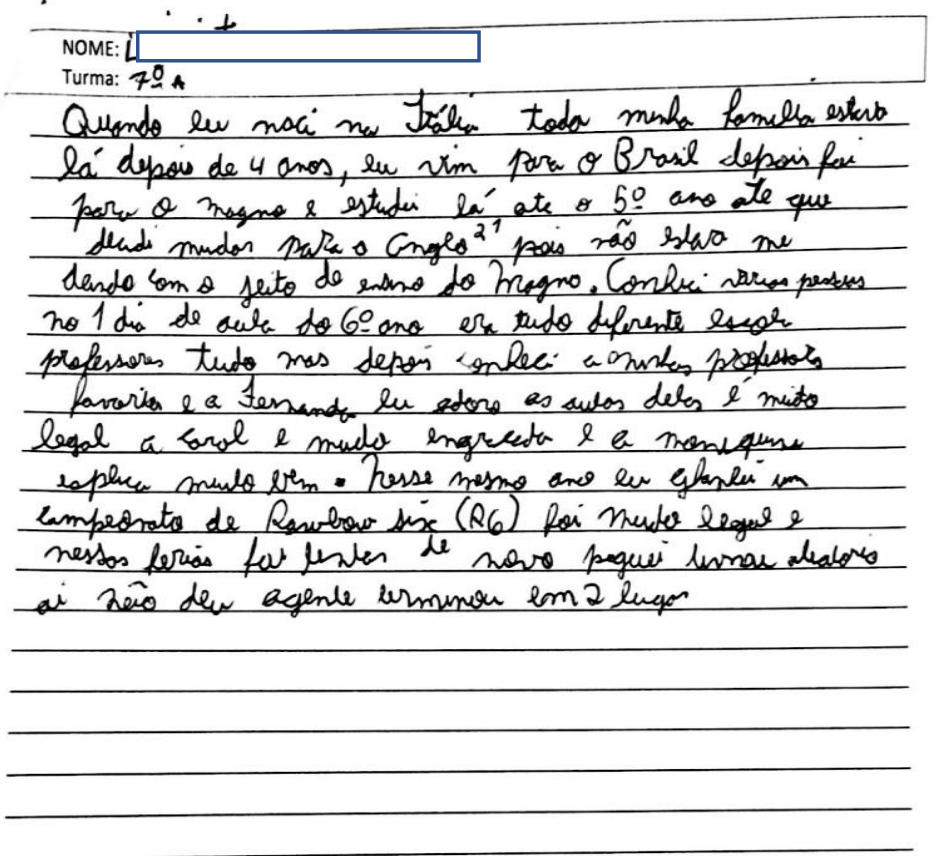

Quando eu naci na Itália toda minha familia estava lá depois de 4 anos, eu vim para o Brasil depois foi para o Magno e estudei lá ate $05^{\circ}$ ano ate que decidi mudar para o Anglo ${ }^{21}$ pois não estava me dando com o jeito de ensino do Magno. Conheci varias pessoas no 1 dia de aula do $6^{\circ}$ ano era tudo diferente escola professores tudo mas depois conheci a minha professora favorita e a Fernanda eu adoro as aulas delas é muito legal a carol e muito engraçada e a monique esplica muito bem. Nesse mesmo ano eu ganhei um campeonato de Raibow six (R6) foi muito legal e nessas ferias foi tentar de novo peguei $[X]$ aleatorio ai não deu agente terminou em 2 lugar 
Texto 16

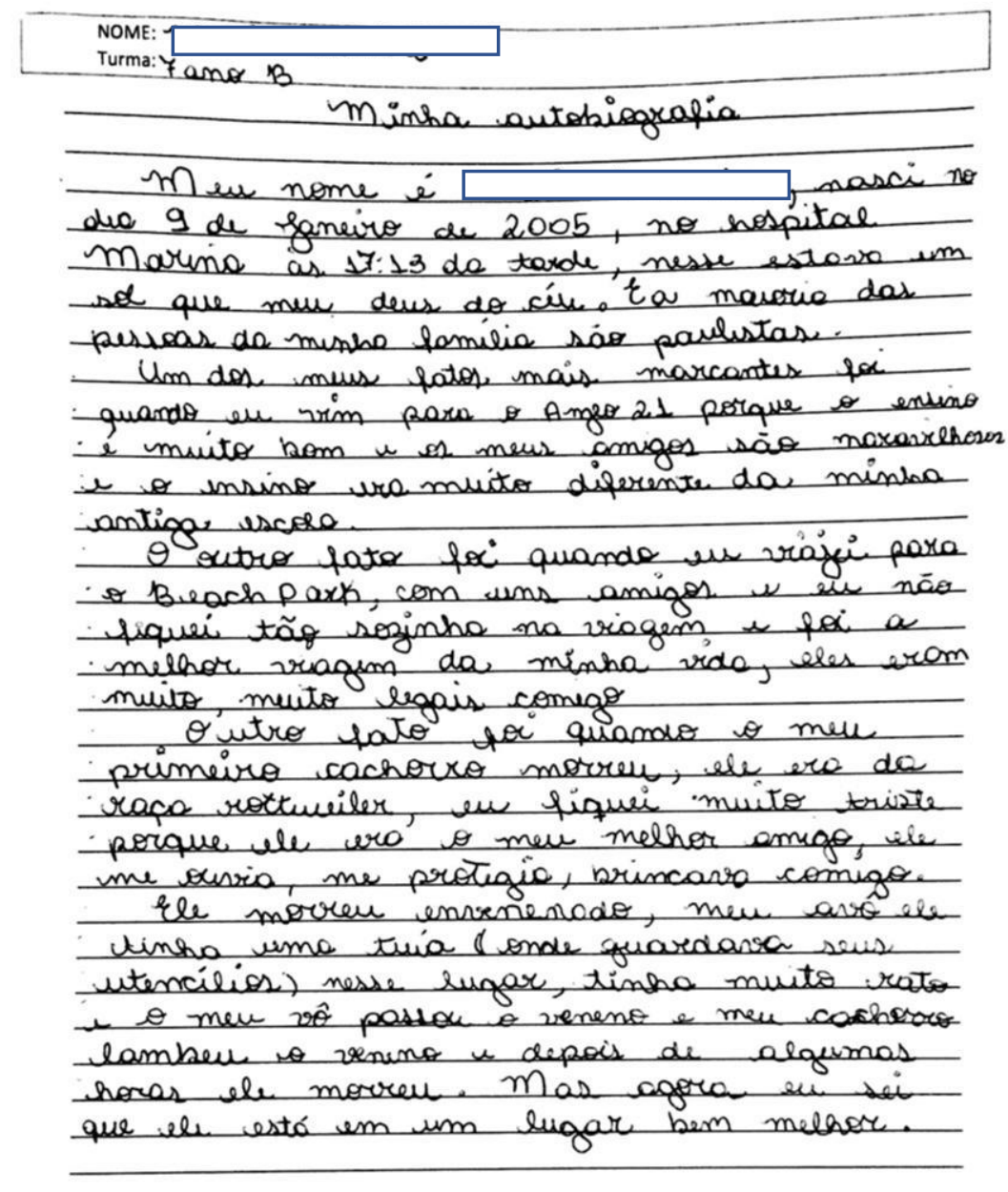

Minha autobiografia

Meu nome é M. E., nasci no dia 9 de janeiro de 2005, no hospital Marina as 17:13 da tarde, nesse estava um sol que meu deus do céu. E a maioria das pessoas da minha família são paulistas.

Um dos meus fatos mais marcantes foi quando eu vim para o Anglo 21 porque o ensino é muito bom e os meus amigos são maravilhosos e o ensino era muito diferente da minha antiga escola.

O outro fato foi quando eu viajei para o Beach Park, com uns amigos e eu não fiquei tão sozinha na viagem e foi a melhor viagem da minha vida, eles era muito, muito legais comigo

O outro fato foi quando o meu primeiro cachorro morreu, ele era da raça rottweiler, eu fiquei muito triste porque ele era o meu melhor amigo, ele me ouvia, em protegia, brincava comigo.

Ele morreu envenenado, meu avô ele tinha uma teía (onde guardava seus utencílios) nesse lugar, tinha muito rato e o meu vô passou o veneno e o meu cachorro lambeu o veneno e depois de algumas horas ele morreu. Mas agora eu sei que ele está em um lugar bem melhor. 
Texto 17

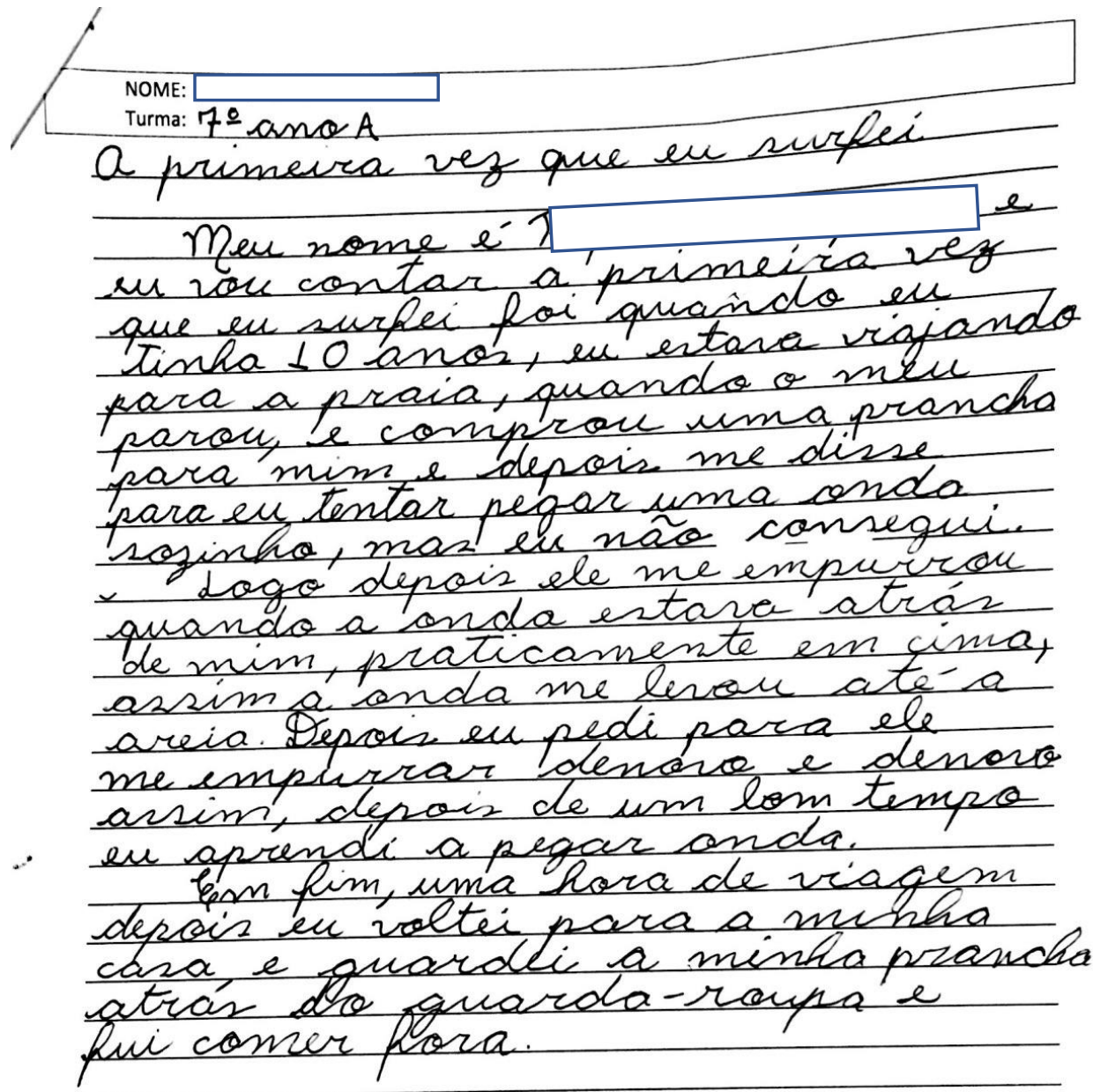

A primeira vez que eu surfei

Meu nome é R. S. e eu vou contar a primeira vez que eu surfei foi quando eu tinha 10 anos, eu estava viajando para a praia, quando o meu parou, e comprou uma prancha para mim e depois me disse para eu tentar pegar uma onda sozinho, mas eu não consegui.

Logo depois ele me empurrou quando a onda estava atrás de mim, praticamente em cima, assim a onda me levou até a areia. Depois eu pedi para ele me empurrar denovo e denovo assim, depois de um bom tempo eu aprendi a pegar onda.

Em fim, uma hora de viagem depois eu voltei para a minha casa e guardei a minha prancha atrás do guarda-roupa e fui comer fora. 
Texto 18

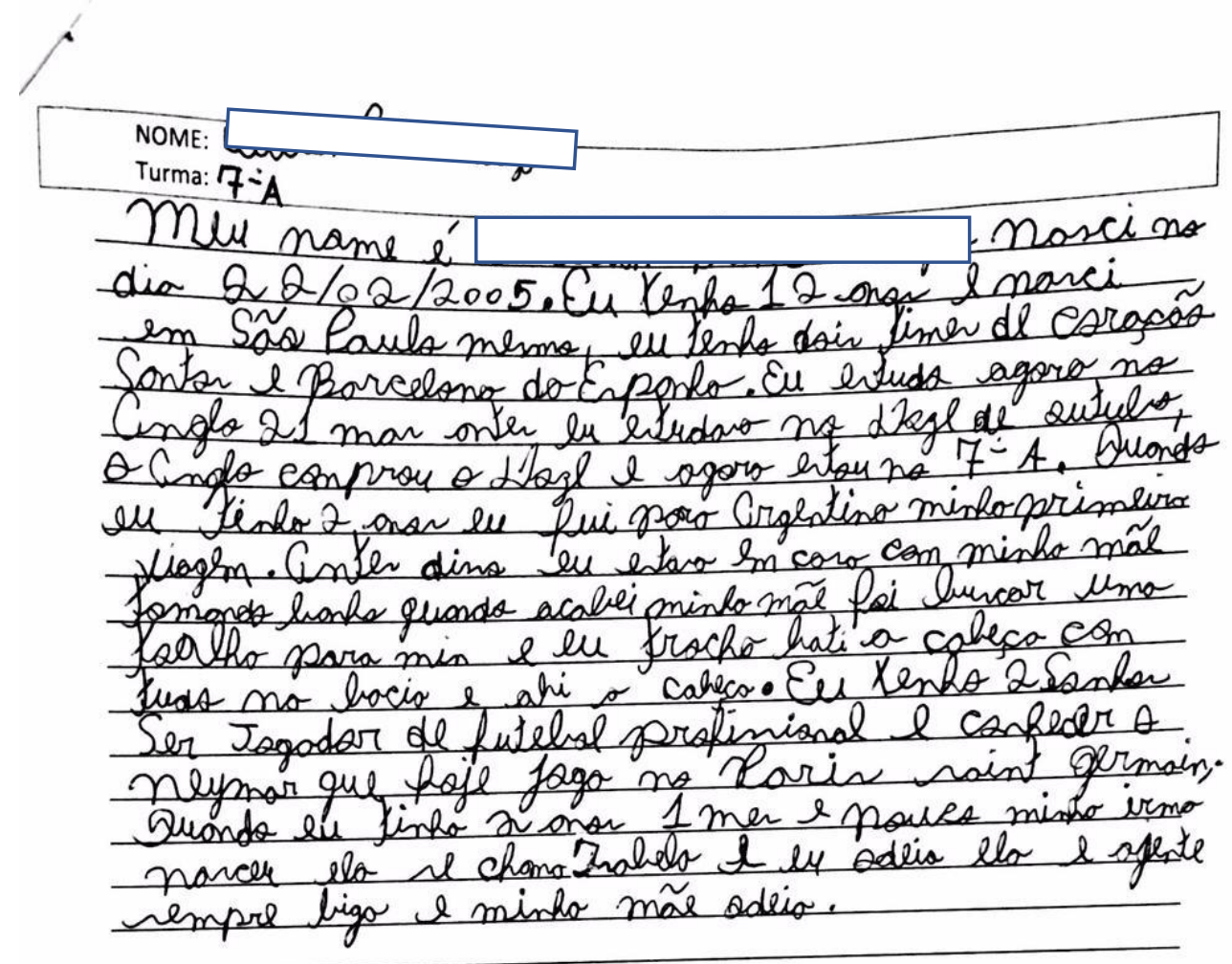

Meu nome é W. P. T. nasci no dia 22/02/2005. Eu tenho 12 anos e nasci em São Paulo mesmo, eu tenho dois times de coração Santos e Barcelona da Espanha. Eu estudo agora no Anglo 21 mas antes eu estudava no Doze de outubro, o Anglo comprou o Doze a agora estou na $7^{\circ} \mathrm{A}$. Quando eu tinha 2 anos eu fui para Argentina minha primeira viagem. Antes disso eu estava em casa com minha mãe tomando banho quando acabei minha mãe foi buscar uma toalha para mim e eu XIS bati a cabeça com tudo na bacia e abri a cabeça. Eu tenho 2 sonhos Ser Jogador de futebol profissional e conhecer o Neymar que hoje joga no Paris saint Germain;

Quando eu tinha 2 anos 1 XIS e pouco minha irma nasceu ela se chama Isabela e eu odeio ela e a gente sempre briga e minha mãe odeia. 
Texto 19

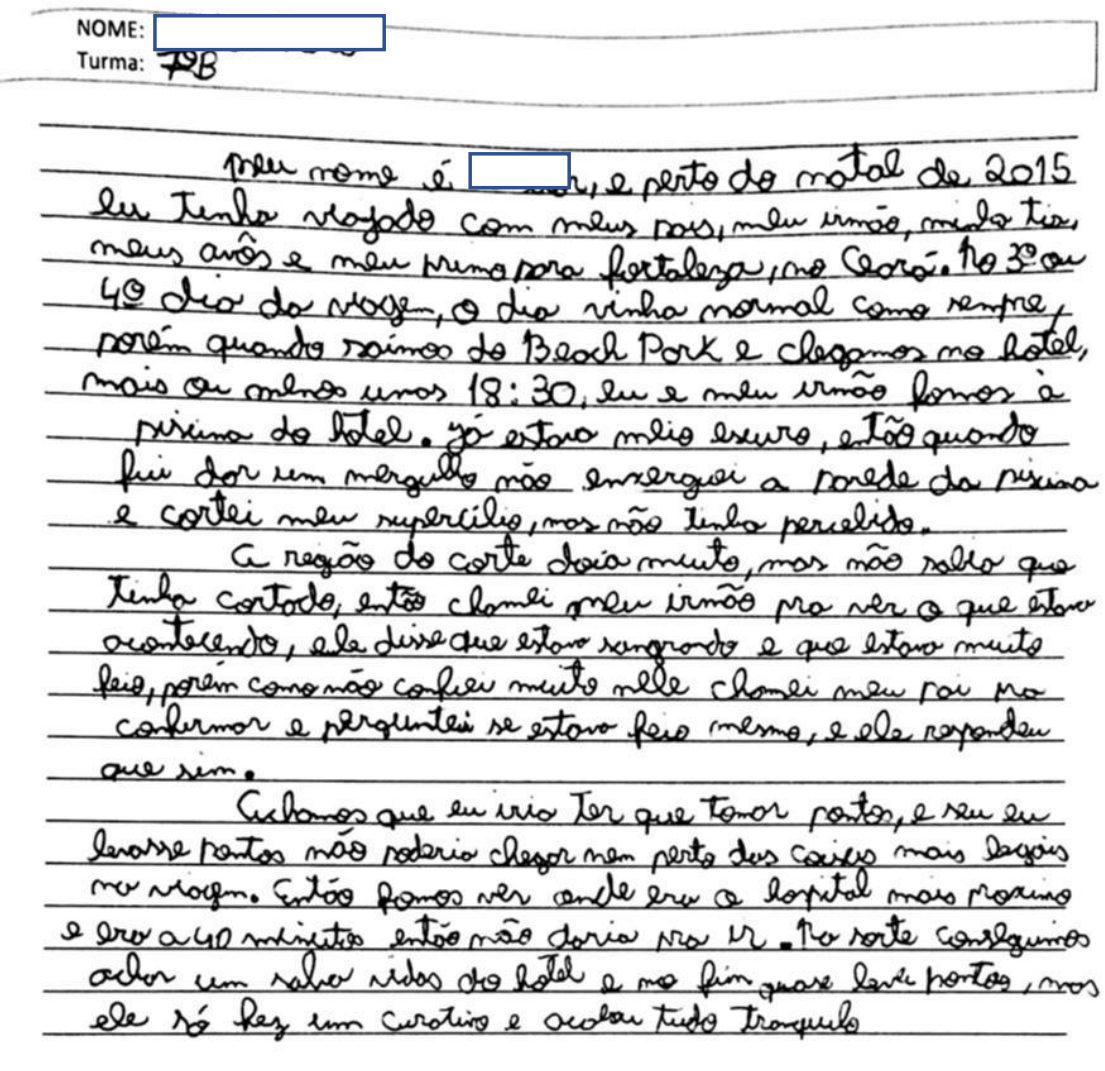

Meu nome é V., e perto do Natal de 2015 eu tinha viajado com meus pais, meu irmão, minha tia, meus avôs e minha prima para fortaleza, no Ceará. No 3o ou 4ํㅜㄴ dia da viagem, o dia vinha normal como sempre, porém quando saímos do Beach Park e chegamos no Hotel, mais ou menos uma 18:30, eu e meu irmão fomos à piscina do hotel. Já estava meio escuro, então quando fui dar um mergulho não enxerguei a parede da piscina e cortei meu supercílio, mas não tinha percebido.

A região do corte doia muito, mas não sabia que tinha cortado, então chamei meu irmão pra ver o que estava acontecendo, ele disse que estava sangrando e estava muito feio, porém como não confiei muito nele chamei meu pai pra confirmar e perguntei se estava feio mesmo, e ele respondeu que sim.

Achamos que eu iria ter que tomar pontos, e se eu levasse pontos não poderia chegar nem perto das coisas mais legais na viagem. Então fomos ver onde era o hospital mais proximo e era a 40 minutos então não daria pra ir. Na sorte conseguimos achar um salva vidas do hotel e no fim quase levei pontos, mas ele só fem um curativo e acabou tudo tranquilo 
Texto 20

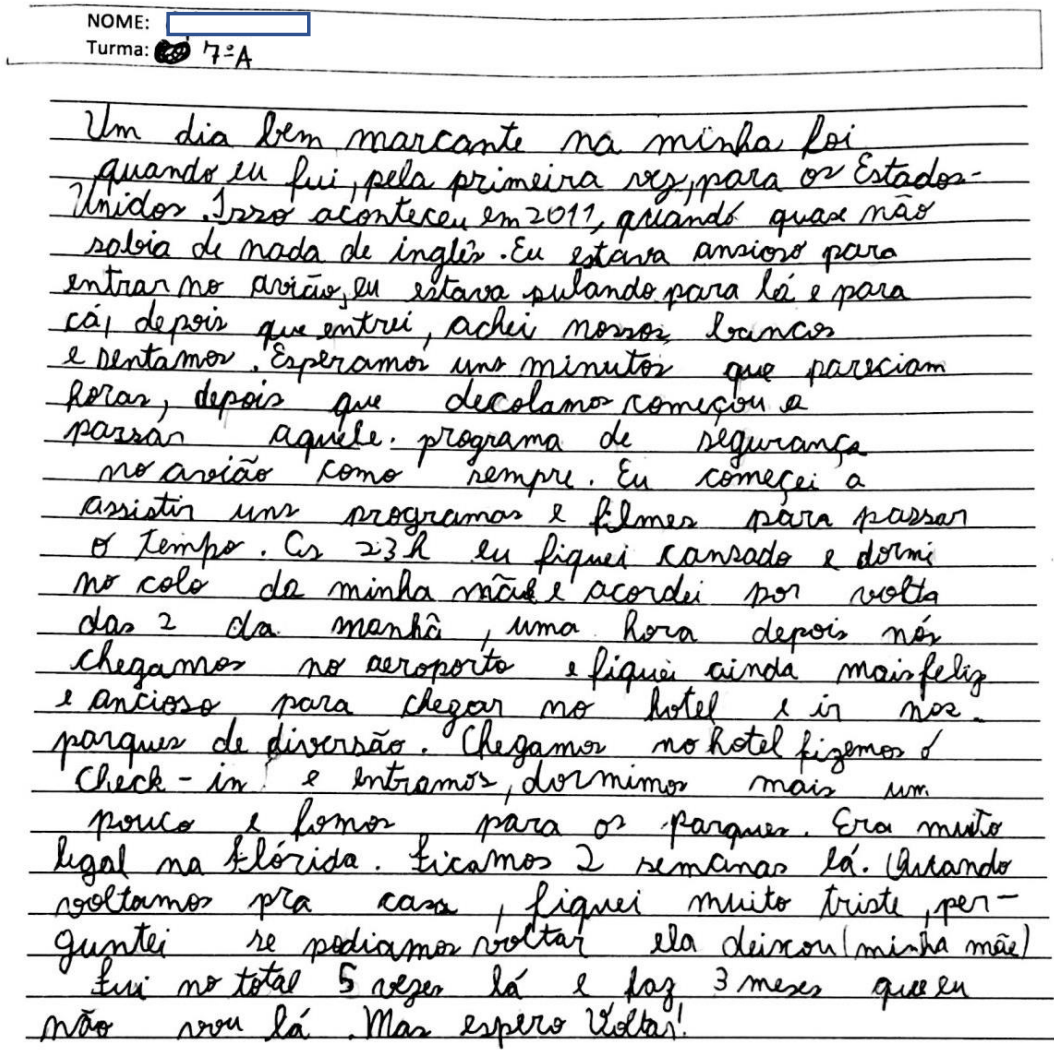

Um dia bem marcante na minha vida foi quando eu fui, pela primeira vez, para os Estados-Unidos. Isso aconteceu em 2011, quando quase não sabia nada de inglês. Eu estava ansioso para entrar no avião,eu estava pulando para lá e para cá, depois que entrei, achei nossos bancos e sentamos. Esperamos uns minutos que pareciam horas, depois que decolamos começou a passar aquele programa de segurança no avião como sempre. Eu comecei a assistir uns programas e filmes para passar o tempo. As $23 \mathrm{~h}$ eu fiquei cansado e dormi no colo da minha mãe e acordei por volta das 2 da manhã, uma hora depois nós chegamos no aeroporto e fiquei ainda mais feliz e ancioso para chegar no hotel e ir nos parques de diversão. Chegamos no hotel fizemos o Check-in e entramos, dormimos mais um pouco e fomos para os parques. Era muito legal na Flórida. Ficamos 2 semanas lá. Quando voltamos pra casa, fiquei muito triste, perguntei se podiamos voltar ela deixou (minha mãe)

Fui no total 5 vezes lá e faz 3 meses que eu não vou lá. Mas espero voltar! 
Texto 21

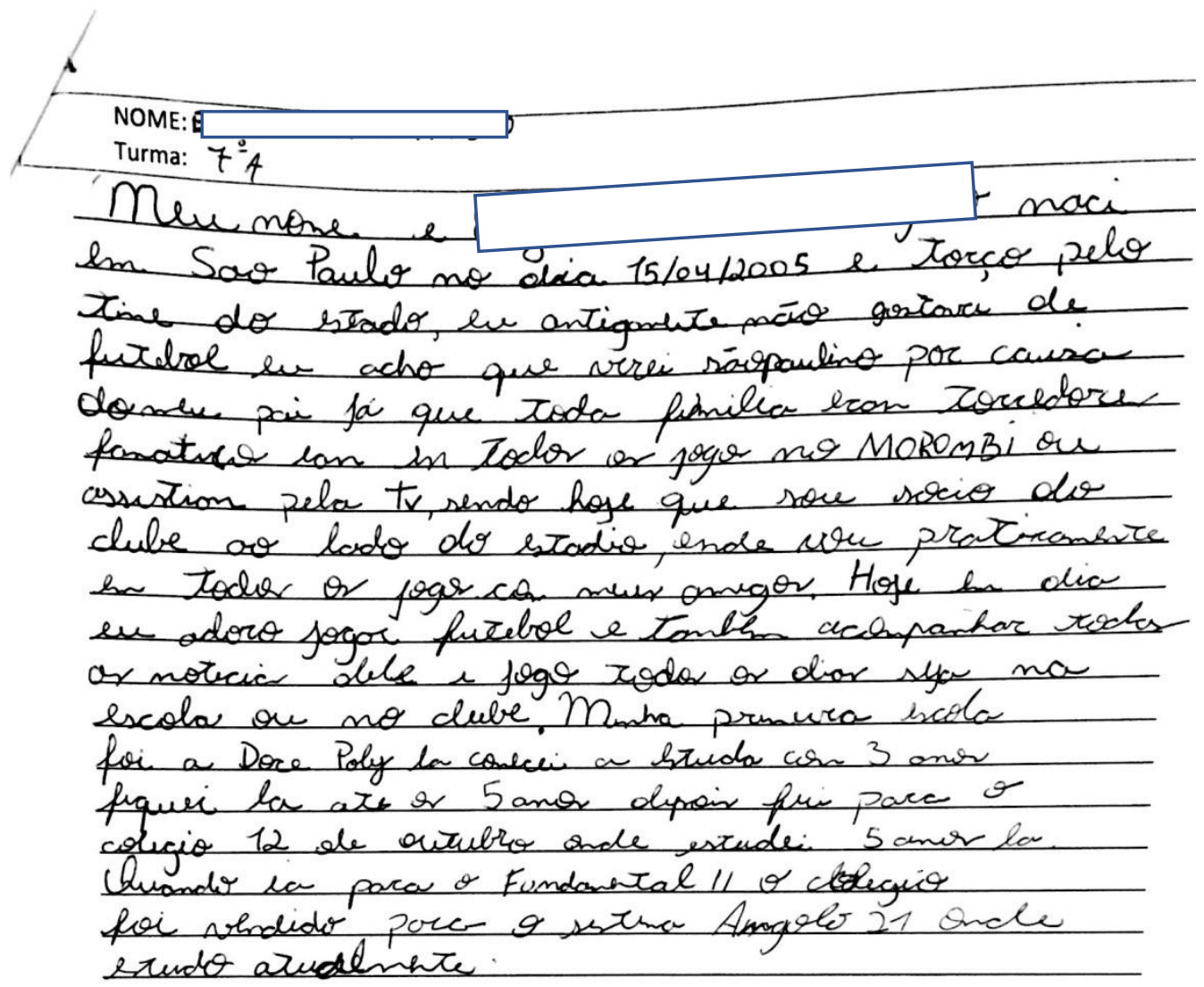

Meu nome e E. F. M. naci em Sao Paulo no dia 15/04/2005 e torço pelo time do estado, eu antigamente não gostava de futebol eu acho que virei sãopaulino por causa do meu pai já que toda família eran torcedor fanatico ian em todos os jogo no MOROMBI ou assistiam pela TV, sendo hoje que sou socio do clube ao lado do estadio, onde vou praticamente em todos os jogos ca meus amigos. Hoje em dia eu adoro jogar futebol e tambem acompanhar todas as noticia dele e jogo todo os dias na escola ou no clube. Minha primeira escola foi a Doce Poly la comecei a estudar com 3 anos fiquei la ate os 5 depois fui para o colegio 12 de outubro onde estudei 5 anos la.

Quando ia para o Fundamental II o colegio foi vendido para o sistema Anglo 21 onde estudo atualmente. 
Texto 22

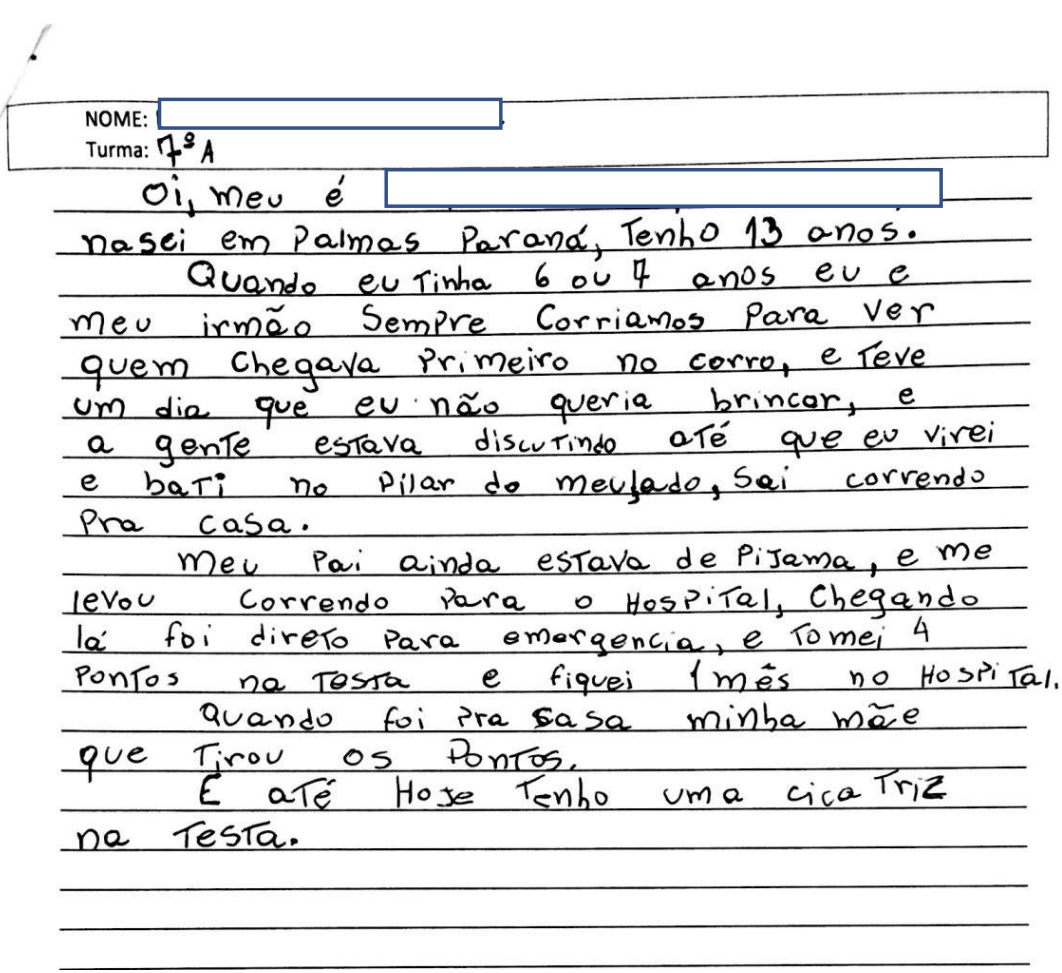

Oi, meu é F. M. Z., nasci em Palmas Paraná, tenho 13 anos.

Quando eu tinha 6 ou 7 anos eu e meu irmão sempre corriamos para ver quem chegava primeiro no carro, e teve um dia que eu não queria brincar, e a gente estava discutindo até que eu virei e bati no pilar do meu lado, sai correndo pra casa.

Meu pai ainda estava de pijama, e me levou correndo para o hospital, chegando lá foi direto para emergencia, e tomei 4 pontos na testa e fiquei 1 mês no hospital.

Quando foi pra casa minha mãe que tirou os pontos.

E até hoje tenho uma cicatriz na testa. 
Texto 23

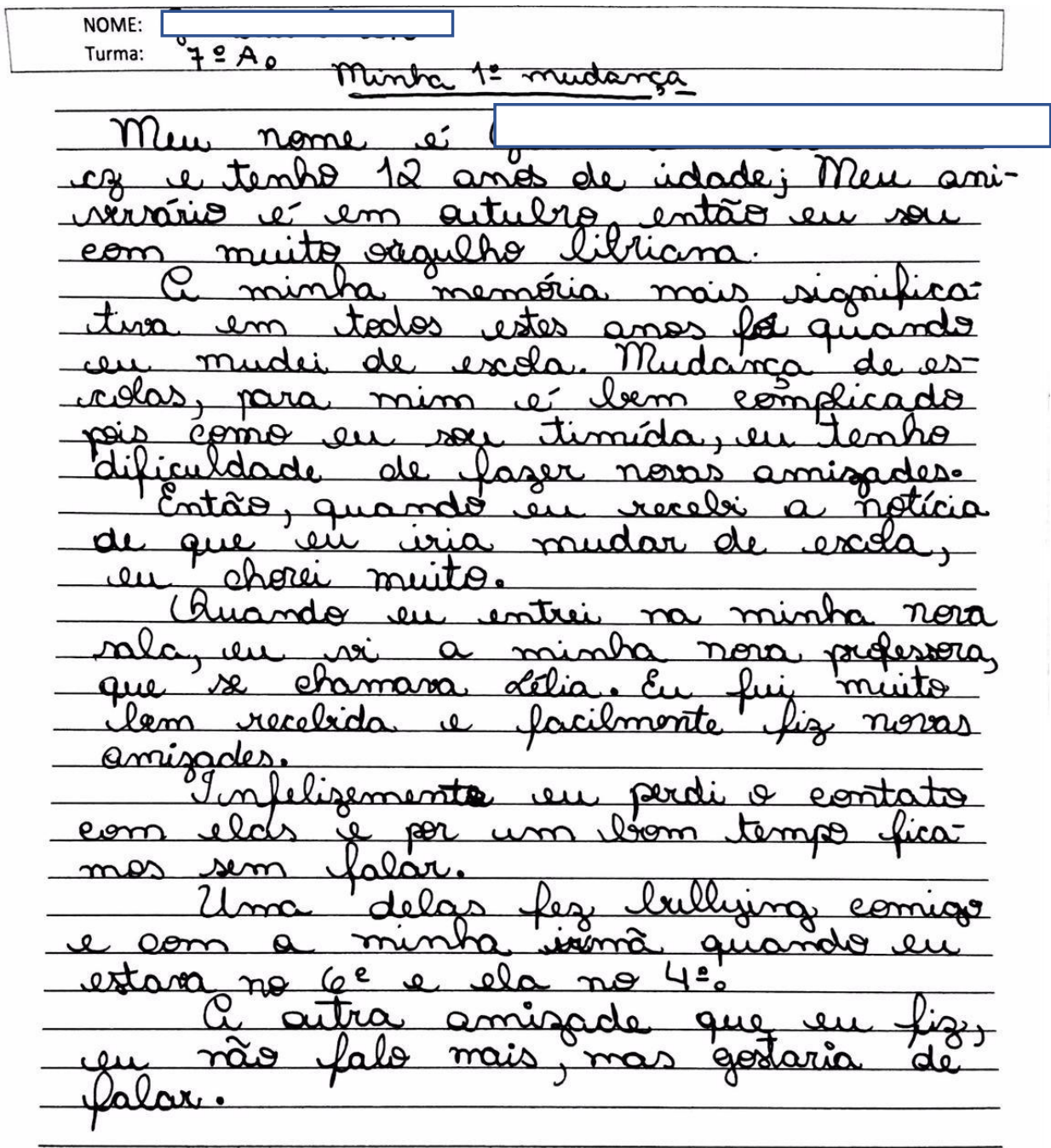

Minha 1ํmudança

Meu nome é G. T. W. e tenho 12 anos de idade; Meu aniversário é em outubro então eu sou com muito orgulho libriana.

A minha memória mais significativa em todos estes anos foi quando eu mudei de escola. Mudança de escolas, para mim é bem complicado pois como eu sou tímida, eu tenho dificuldade de fazer novas amizades.

Então, quando eu recebi a notícia de que eu iria mudar de escola, chorei muito.

Quando eu entrei na minha nova sala, eu vi a minha nova professora, que se chamava Lélia. Eu fui muito bem recebida e facilmente fiz novas amizades.

Infelizmente eu perdi o contato com elas e por um bom tempo ficamos sem falar.

Uma delas fez bullying comigo e com a minha irmã quando eu estava no $6^{\circ}$ e ela no $4^{\circ}$.

A outra amizade que eu fiz, eu não falo mais, mas gostaria de falar. 


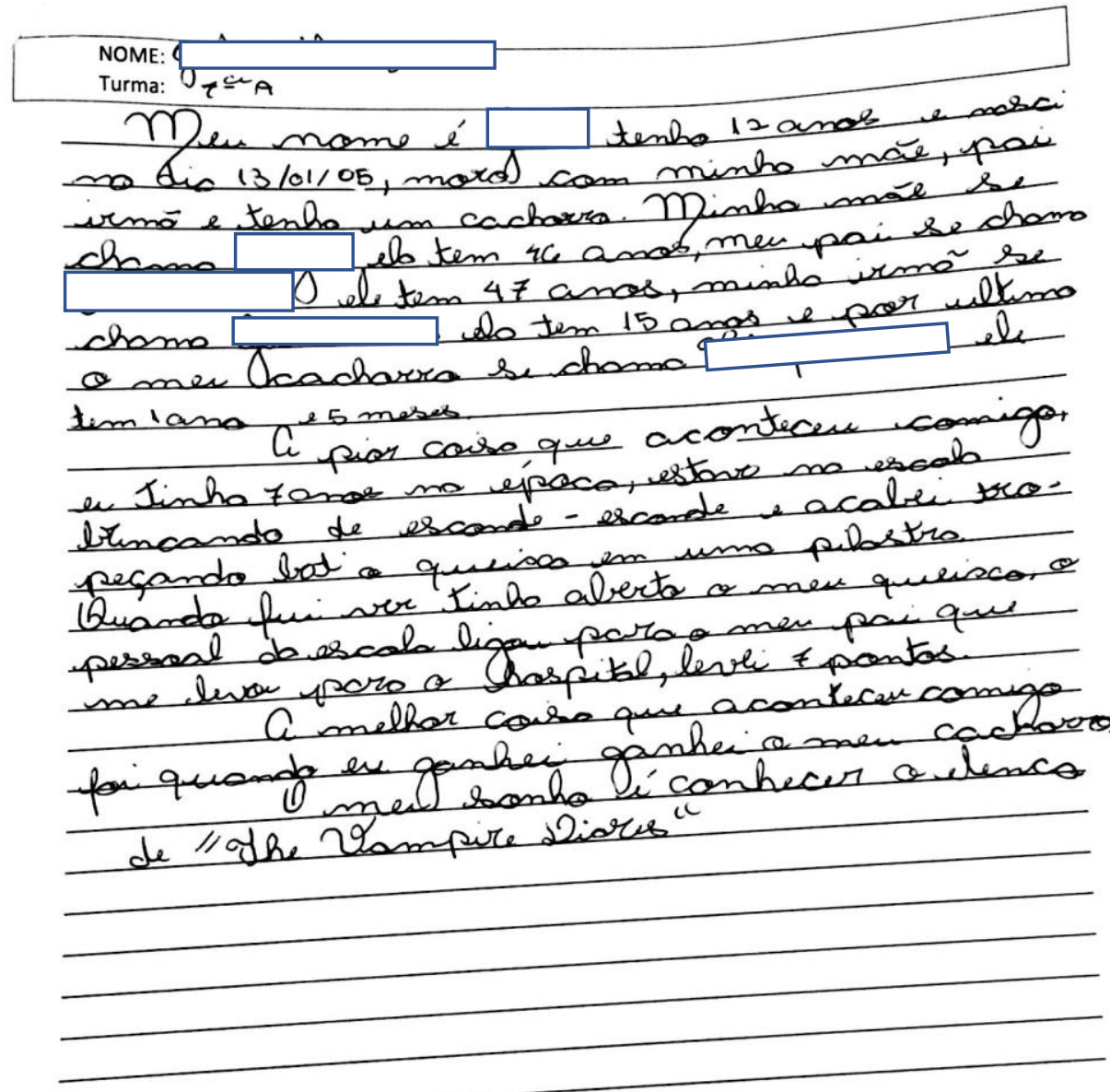

Meu nome é G. tenho 12 anos e nasci no dia 13/01/05, moro com minha mãe, pai irmã e tenho um cachorro. Minha mãe se chama L. ela tem 46 anos, meu pai se chama A. ele tem 47 , minha irmã se chama $G$. ela tem 15 anos e por ultimo o meu cachorro se chama F. ele tem 1 ano e 5 meses.

A pior coisa que aconteceu comigo, eu tinha 7 anos na época, estava na escola brincando de esconde-esconde e acabei tropeçando bati o queixo em uma pilastra.

Quando fui ver tinha aberto o meu queixo, o pessoal da escola ligou para o meu pai que me levou para o hospital, levei 7 pontos.

A melhor coisa que aconteceu comigo foi quando eu ganhei ganhei o meu cachorro.

O meu sonho é conhecer o elenco de "The Vampire Diares" 
Texto 25

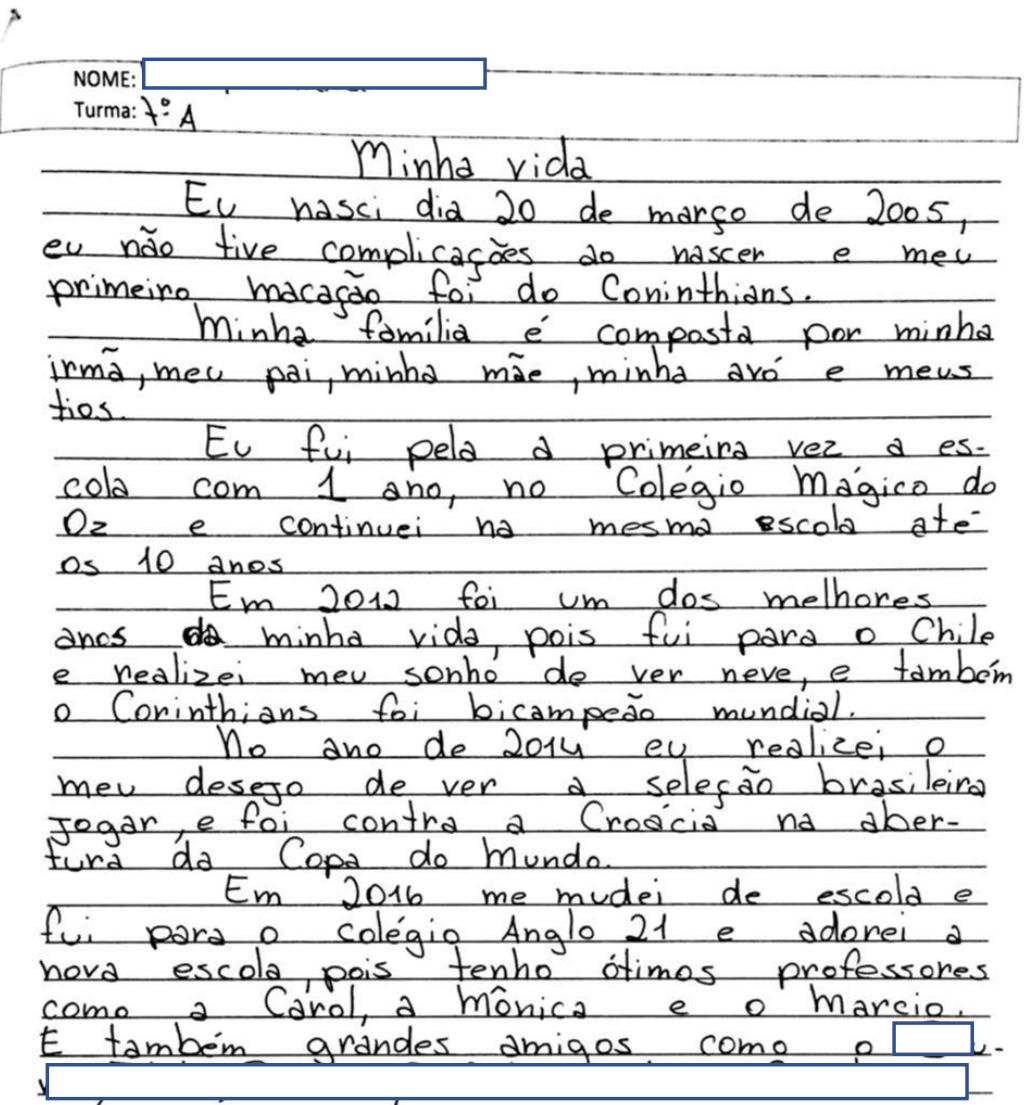

Minha vida

Eu nasci dia 20 de março de 2005, eu não tive complicações ao nascer e meu primeiro macação foi do Corinthians.

Minha família é composta por minha irmã, meu pai, minha mãe, minha avó e meus tios.

Eu fui pela a primeira vez a escola com 1 ano, no Colégio Mágico do Oz e continuei na mesma escola até os 10 anos.

Em 2012 foi um dos melhores anos da minha vida, pois fui para o Chile e realizei meu sonho de ver neve, e também o Corinthians foi bicampeão mundial.

No ano de 2014 eu realizei o meu desejo de ver a seleção brasileira jogar, e foi contra a Croácia na abertura da Copa do Mundo.

Em 2016 me mudei de escola e fui para o colégio Anglo 21 e adorei a nova escola, pois tenho ótimos professores como a Carol, a Mônica e o Marcio. E também grandes amigos como o B., I., P., R. e A. C. 
Texto 26

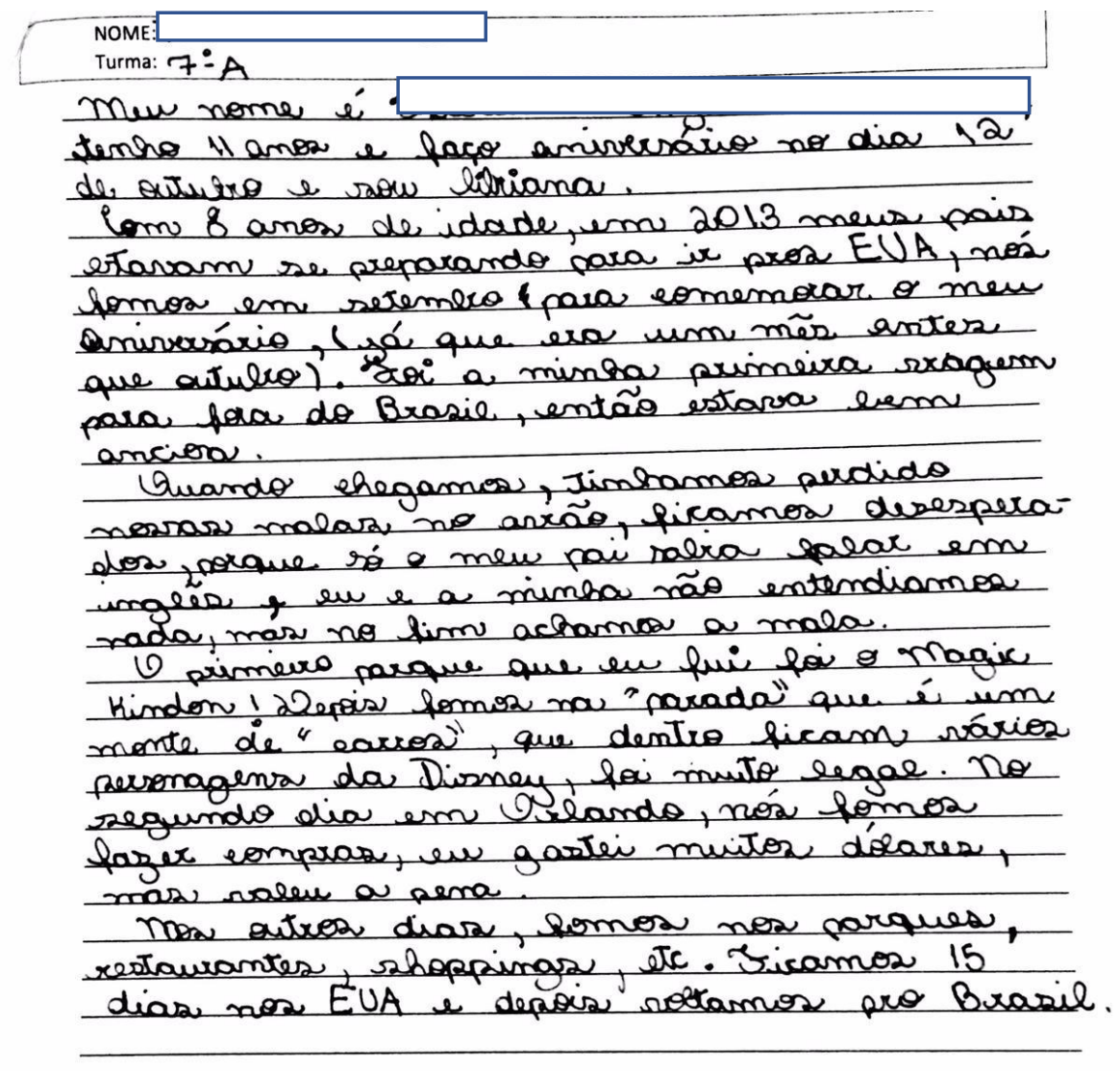

Meu nome é I. M. de A. , tenho 11 anos e faço aniversário no dia 12 de outubro e sou libriana.

Com 8 anos de idade, em 2013, meus pais estavam se preparando para ir pros EUA, nós fomos em setembro para comemorar o meu aniversário, (já que era um mês antes que outubro). Foi a minha primeira viagem para fora do Brasil, então estava bem anciosa.

Quando chegamos, tinhamos perdido nossas malas no avião, ficamos desesperados, porque só o meu pai sabia falar em inglês e eu e a minha não antendiamos nada, mas no fim achamos a mala.

O primeiro parque que eu fui foi o Magic Kindon! Depois fomos na "parada" que é um monte de "carros", que dentro ficam vários personagens da Disney, foi muito legal. No segundo dia em Orlando, nós fomos fazer compras, eu gastei muitos dólares, mas valeu a pena.

Nos outros dias, fosmos nos parques, restaurantes, shoppings, etc. Ficamos 15 dias nos EUA e depois voltamos pro Brasil. 
Texto 27

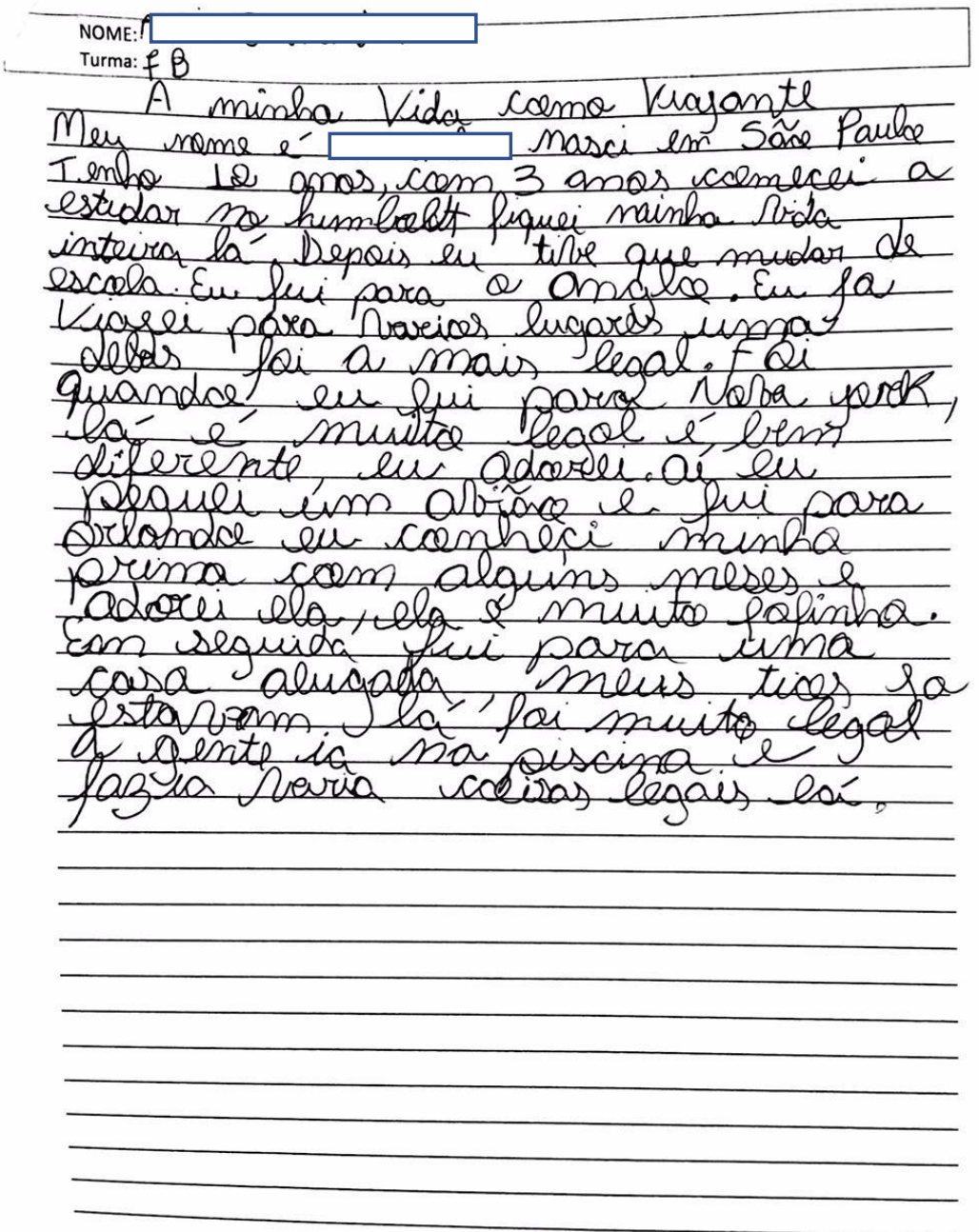

A minha vida como viajante

Meu nome é F. nasci em São Paulo tenho 12 anos, com 3 anos comecei a estudar no humbolt fiquei minha vida inteira lá. Depois eu tive que mudar de escola. Eu fui para o anlgo. Eu ja viajei para varios lugares uma delas foi a mais legal. Foi quando eu fui para Nova york, lá é muito legal é bem diferente, eu adorei. Aí eu peguei um avião e fui para Orlando eu conheci minha prima com alguns meses e adorei ela, ela é muito fofinha.

Em seguida fui para uma casa alugada, meus tios ja estavam lá foi muito legal a gente ia na piscina e fazia varia coisas legais lá. 
Texto 28

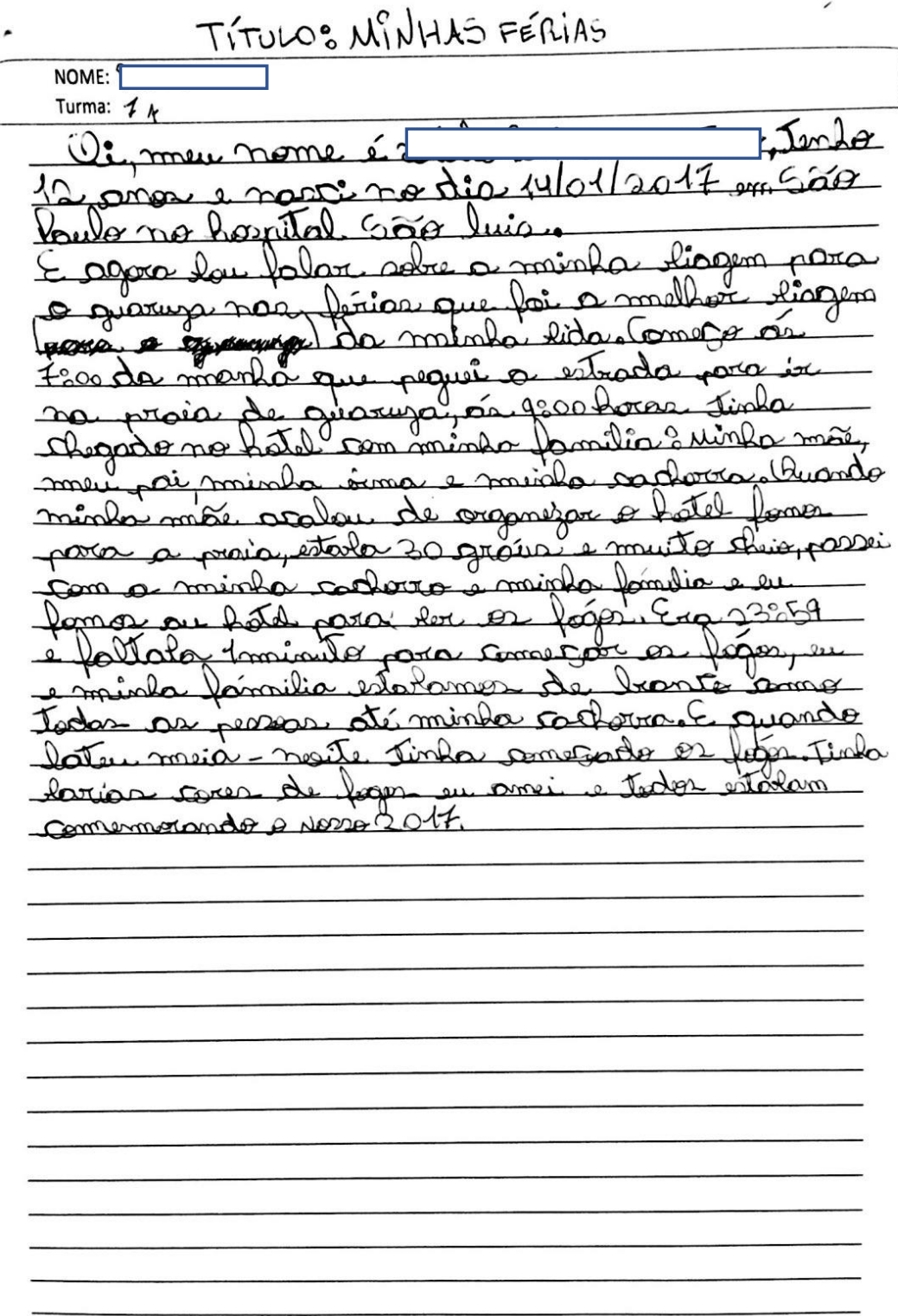

Oi, meu nome é I. P. M., tenho 12 anos e nasci no dia 14/01/2017 em São Paulo no hospital São luis.

E agora eu vou falar sobre a minha viagem para o guaruja nas férias que foi a melhor viagem da minha vida. Começo ás 7:00 da manha que peguei a estrada para ir na praia de guaruja, ás 9:00 horas tinha chegado no hotel com minha familia: minha mãe, meu pai, minha irma e minha cachorra. Quando minha mãe acabou de organizar o hotel fomos para a praia, estava 30 gráus e muito cheio, passei com a minha cachorra e com a minha família e eu fomos ao hotel para ver os fógos. Era 23:59 e faltava 1 minuto para começar os fógos, eu e minha fámilia estavamos de branco como todas as pessoas até minha cachorra. E quando bateu meia-noite tinha começado os fógos. Tinha varias cores de fogos eu amei e todos estavam comemorando o nosso 2017. 
Texto 29

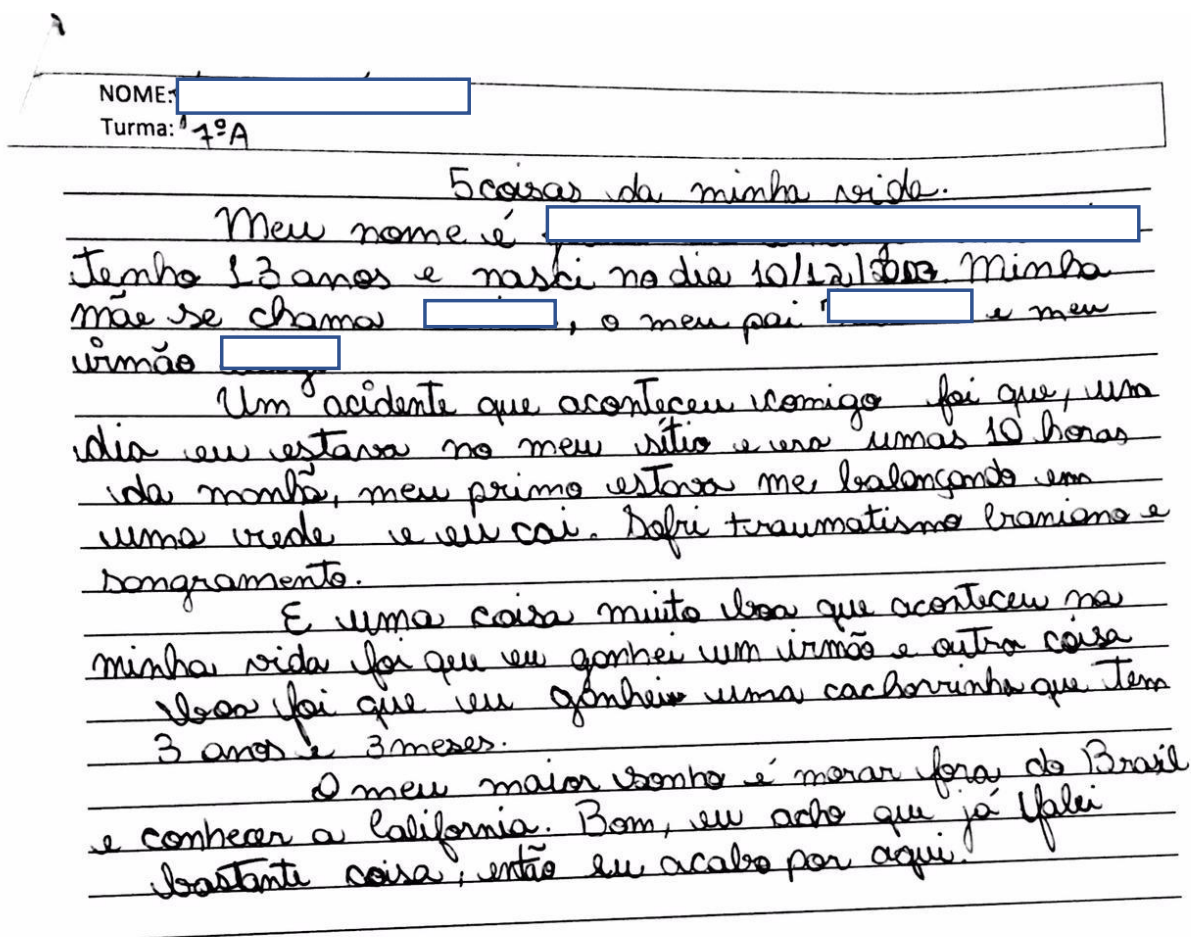

5 coisas da minha vida.

Meu nome é J. L. C. A., tenho 13 anos e nasci no dia 10/12/2003. Minha mãe se chama C., meu pai F. e meu irmão L.

Um acidente que aconteceu comigo foi que, um dia eu estava no meu sítio e era umas 10 horas da manhã, meu primo estava me balançando em uma rede e eu cai. Sofri traumatismo craniano e sangramento.

E uma coisa muito boa que aconteceu na minha vida foi que eu ganhei um irmão e outra coisa boa foi que eu ganhei uma cachorrinha que tem 3 anos e 3 meses.

O meu maior sonho é morar fora do Brasil e conhecer a California. Bom, eu acho que já falei bastante coisa, então eu acabo por aqui. 
Texto 30

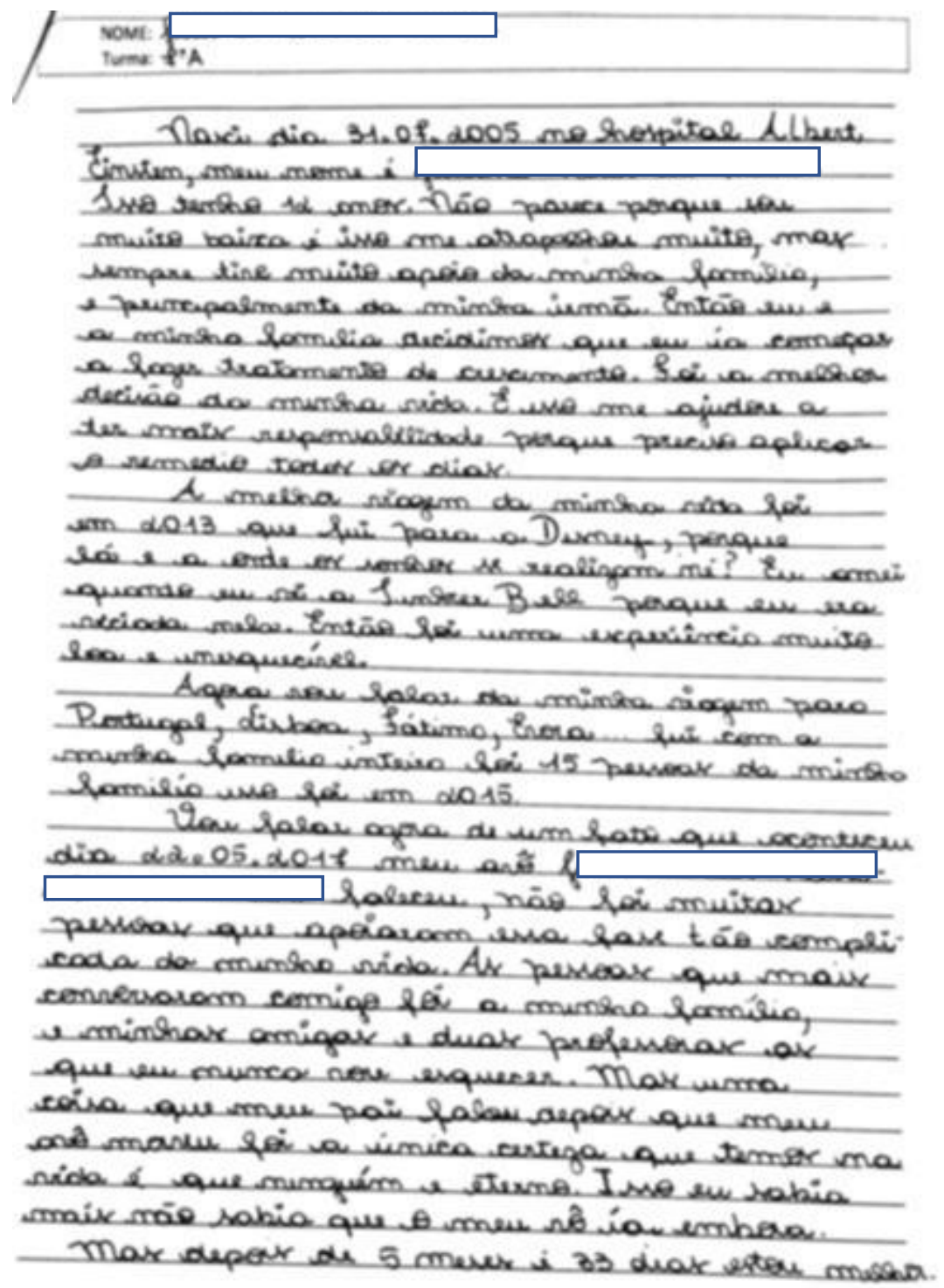

Nasci dia 32.07.2005 no hospital Albert Einstein, meu nome é J. N. de M. Isso tenho 12 anos. Não parece e porque eu sou muito baixa é isso me atrapalha muito, mas sempre tive muito apoio da minha família, e principalmente da minha irmã. Então eu e a minha família decidimos que eu ia começar a fazer tratamento de crescimento. Foi a melhor decisão da minha vida. $E$ isso me ajudou a ter mais responsabilidade porque preciso aplicar o remedio todos os dias.

A melhor viagem da minha vida foi em 2013 que fui para a Disney, porque lá e a onde os sonhos se realizam né? Eu amei quando eu vi a Tinker Bell porque eu era viciada nela. Então foi uma experiência muito boa e inesquecível.

Agora vou falar da minha viagem para Portugal, Lisboa, Fátima, Evora... fui com a minha família inteira foi 15 pessoas da minha família isso foi em 2015.

Vou falar agora de um fato que aconteceu dia 22.05.2017 meu avô J. C. P. de M. faleceu, não foi muitas pessoas que apoiaram essa fase tão complicada da minha vida. As pessoas que mais conversaram comigo foi a minha família, e 
minhas amigas e duas professoras as que eu nunca vou esquecer. Mas uma coisa que meu pai falou depois que meu avô morreu foi a única certeza que temos na vida é que ninguém e eterno. Isso eu sabia mais não sabia que o meu avô ia embora.

Mas depois de 5 meses é 33 dias estou melhor. 
Texto 31

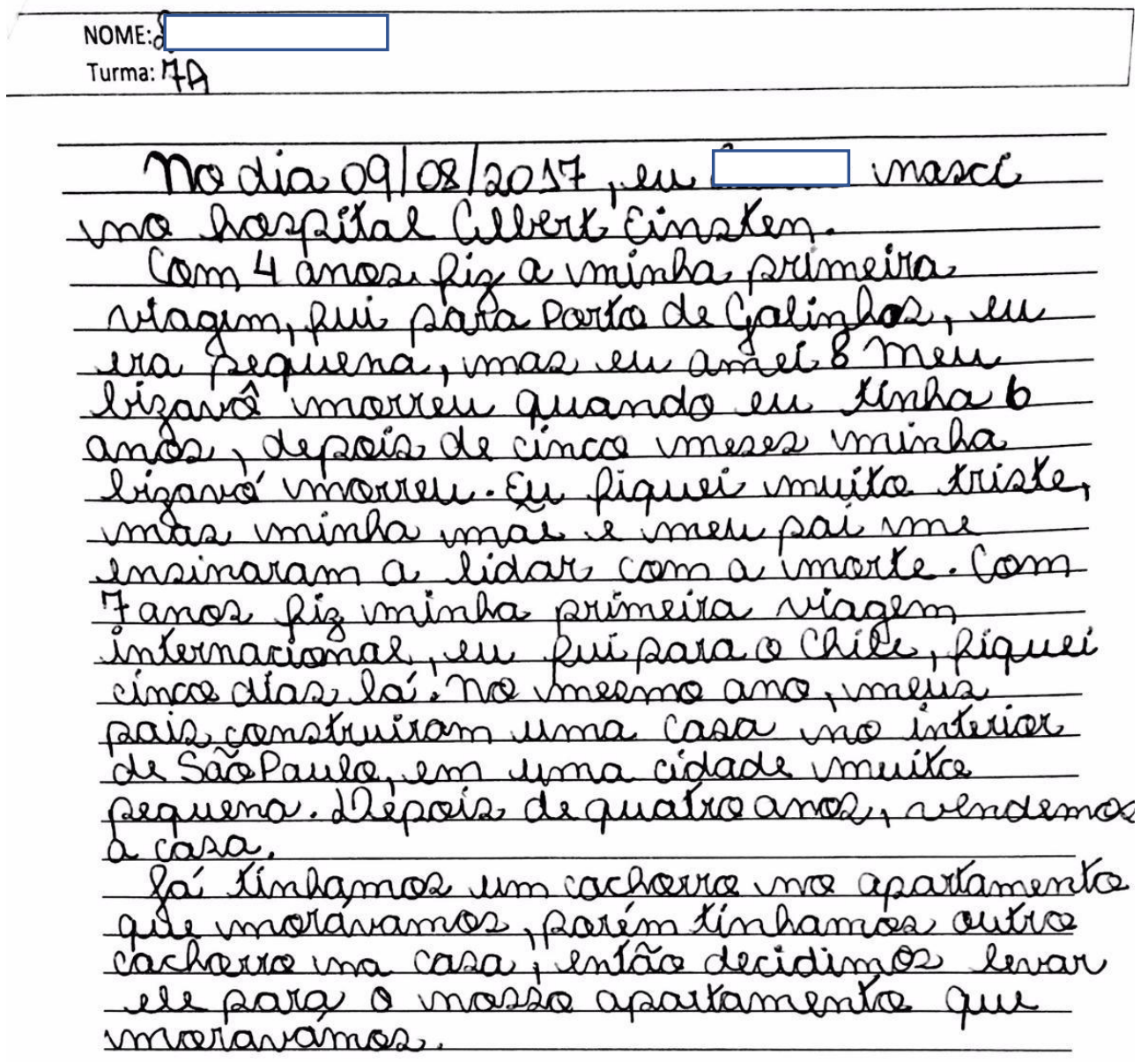

No dia 09/08/2017, eu L.. nasci no hospital Albert Einstein.

Com 4 anos eu fiz a minha primeira viagem, fui para Porto de Galinhas, eu era pequena, mas eu amei. Meu bisavô morreu quando eu tinha 6 anos, depois de cinco meses minha bisavó morreu. Eu fiquei muito triste, mas minha mãe e meu pai me ensinaram a lidar com a morte. Com 7 anos fiz minha primeira viagem internacional, eu fui para o Chile, fiquei cinco dias lá. No mesmo ano, meus pais construiram uma casa no interior de São Paulo, em uma cidade muito pequena. Depois de quatro anos vendemos a casa.

Ja tinhamos um cachorro no apartamento que moravamos, porém tinhamos outro cachorro na casa, então decidimos levar ele para o nosso apartamento que morávamos. 
Texto 32

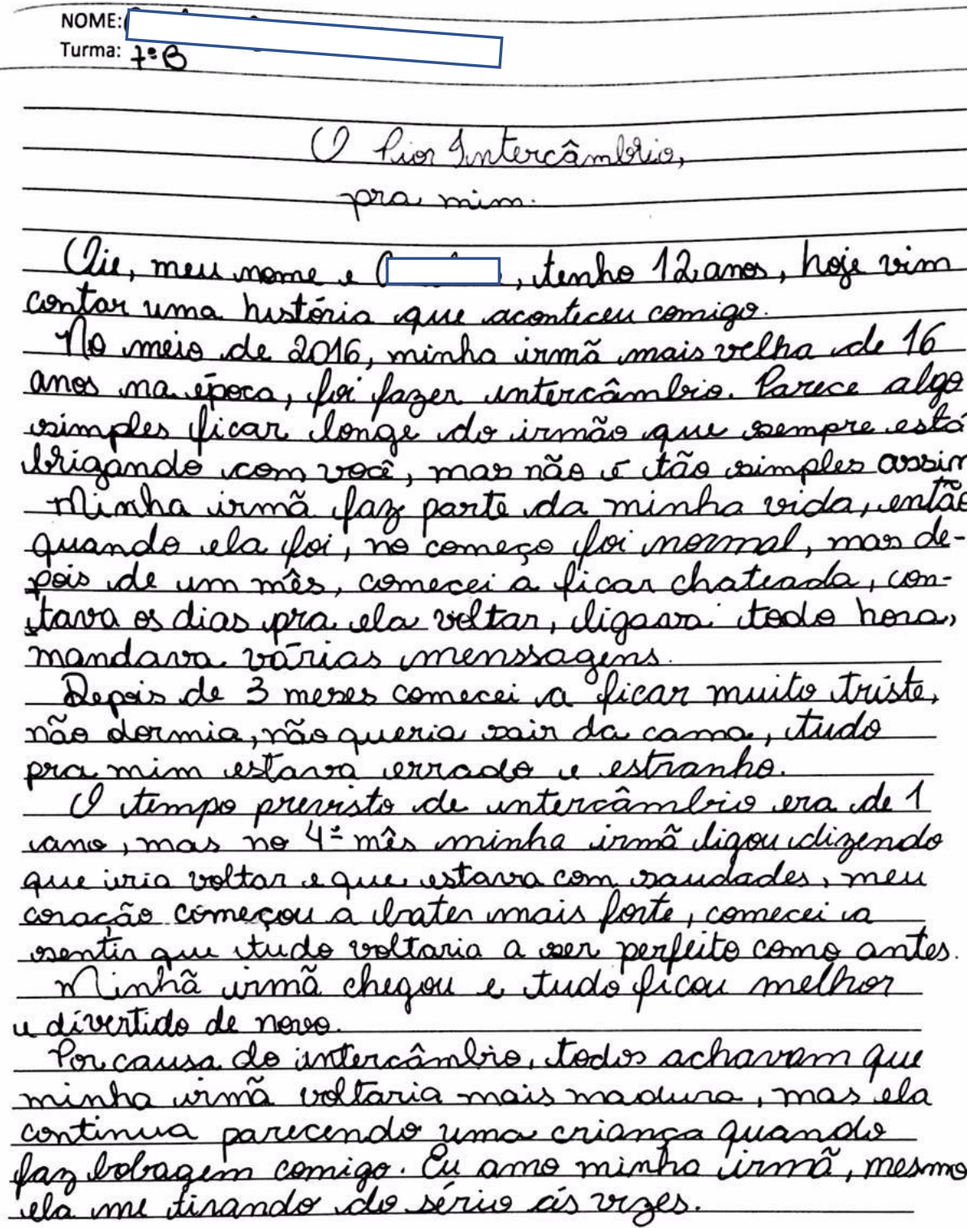

O Pior Intercâmbrio,

pra mim.

Oie, meu nome é C., tenho 12 anos, hoje vim contar uma história que aconteceu comigo.

No meio de 2016, minha irmã mais velha de 16 anos na época, foi fazer intercâmbio. Parece algo simples ficar longe do irmão que sempre está brigando com você, mas não é tão simples assim. 
Minha irmã faz parte da minha vida, então quando ela foi, no começo foi normal, mas depois de um mês, comecei a ficar chateada, contava os dias para ela voltar, ligava toda hora, mandava várias mensagens.

Depois de 3 meses comecei a ficar muito triste, não dormia, não queria sair da cama, tudo pra mim estava errado e estranho.

O tempo previsto de intercâmbio era de 1 ano, mas no $4^{\circ}$ mês minha irmã ligou dizendo que iria voltar e que estava com saudades, meu coração começou a bater mais forte, comecei a sentir que tudo voltaria a ser perfeito como antes.

Minha irmã chegou e tudo ficou melhor e divertido de novo.

Por causa do intercâmbio, todos achavam que minha irmã voltaria mais madura, mas ela continua parecendo uma criança quando faz bobagem comigo. Eu amo minha irmã, mesmo ela me tirando do sério ás vezes. 


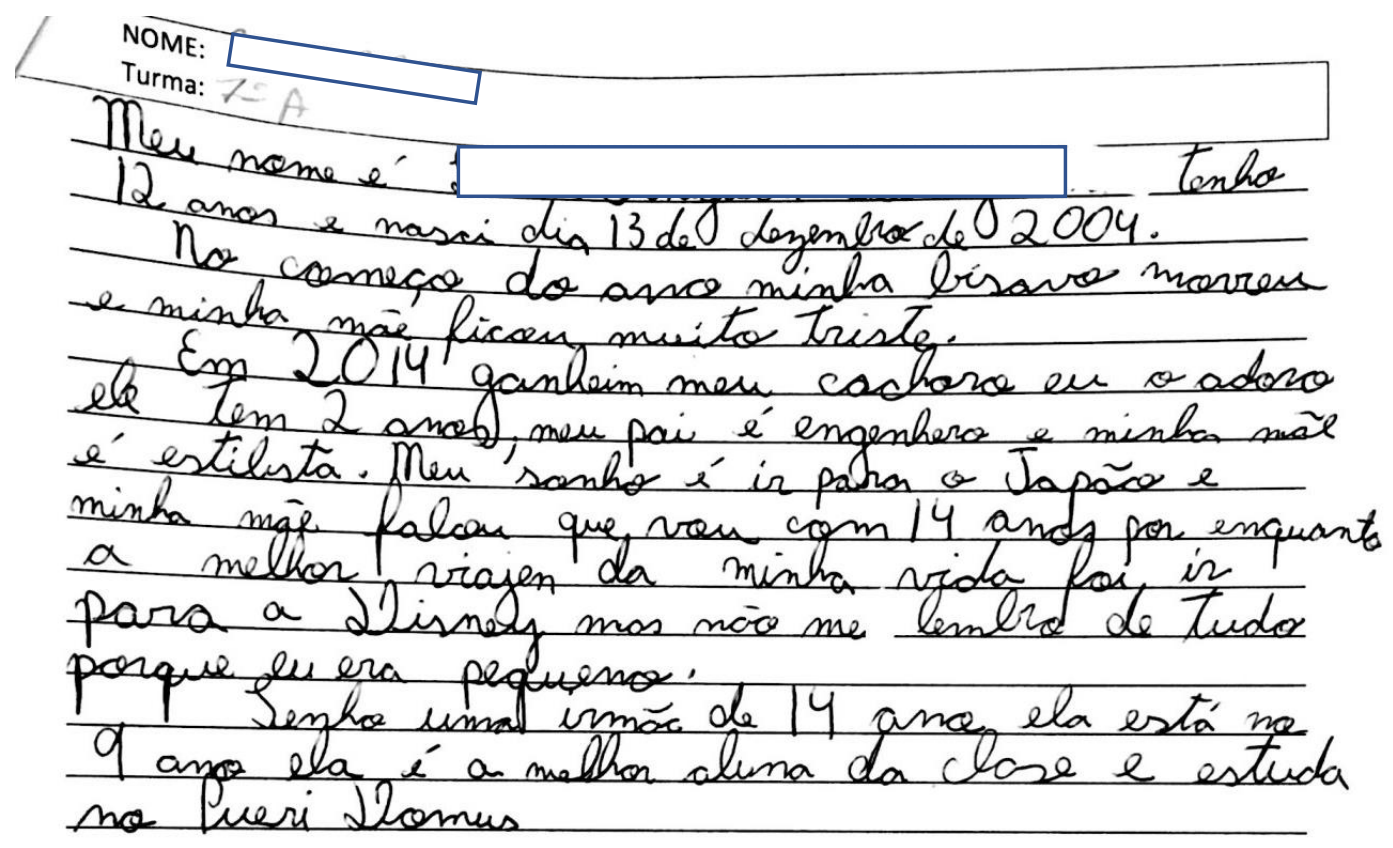

Meu nome é L. T. L. tenho 12 anos e nasci dia 13 de dezembro de 2004.

No começo do ano minha bisavo morreu e minha mãe ficou muito triste.

Em 2014 ganhei meu cachorro eu o adoro ele tem 2 anos, meu pai é engenhero e minha mãe é estilista. Meu sonho é ir para o Japão e minha mãe falou que vou com 14 anos por enquanto a melhor viajem da minha vida foi ir para a Disney mas não me lembro de tudo porque eu era pequeno.

Tenho uma irmã de 14 anos ela está no 9 ano ela é a melhor aluna da clase e estuda no Pueri Domus 


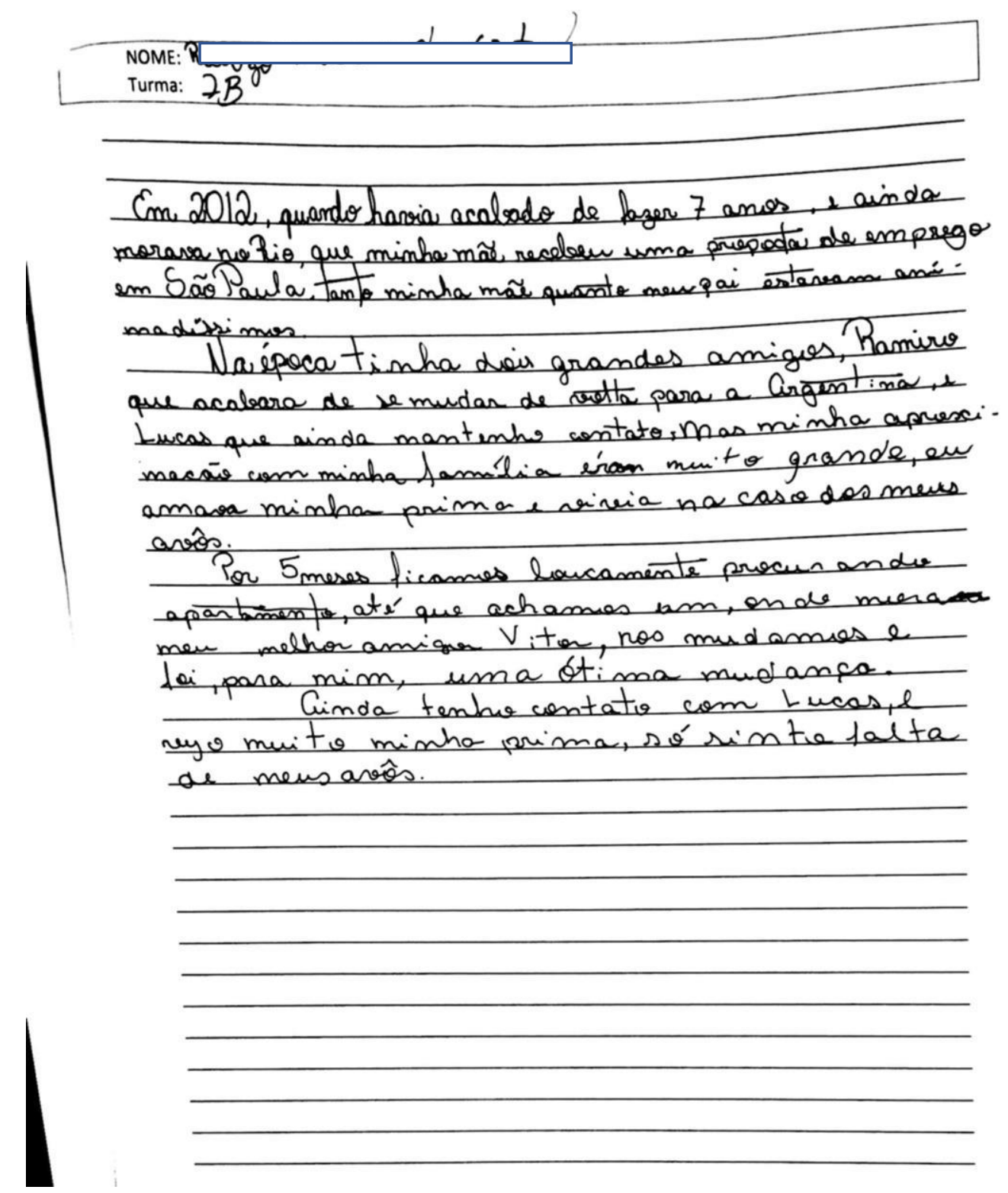

Em 2012, quando havia acabado de fazer 7 anos, e ainda morava no Rio, que minha mãe recebeu uma proposta de emprego em São Paulo. Tanto minha mãe quanto meu pai estavam anímadíssimos.

$\mathrm{Na}$ época tinha dois grandes amigos, Ramiro que acabava de se mudar de volta para a Argentina, e Lucas que ainda mantenho contato. Mas minha aproximacão com minha família éra muito grande, eu amava minha prima e vivia na casa dos meus avôs.

Por 5 meses ficamos loucamente procurando apartamento, até que achamos um, onde mora meu melhor amigo Vitor, nos mudamos e foi, para mim, uma ótima mudança.

Ainda tenho contato com Lucas, e vejo muito minha prima, só sinto falta de meus avôs. 
Texto 35

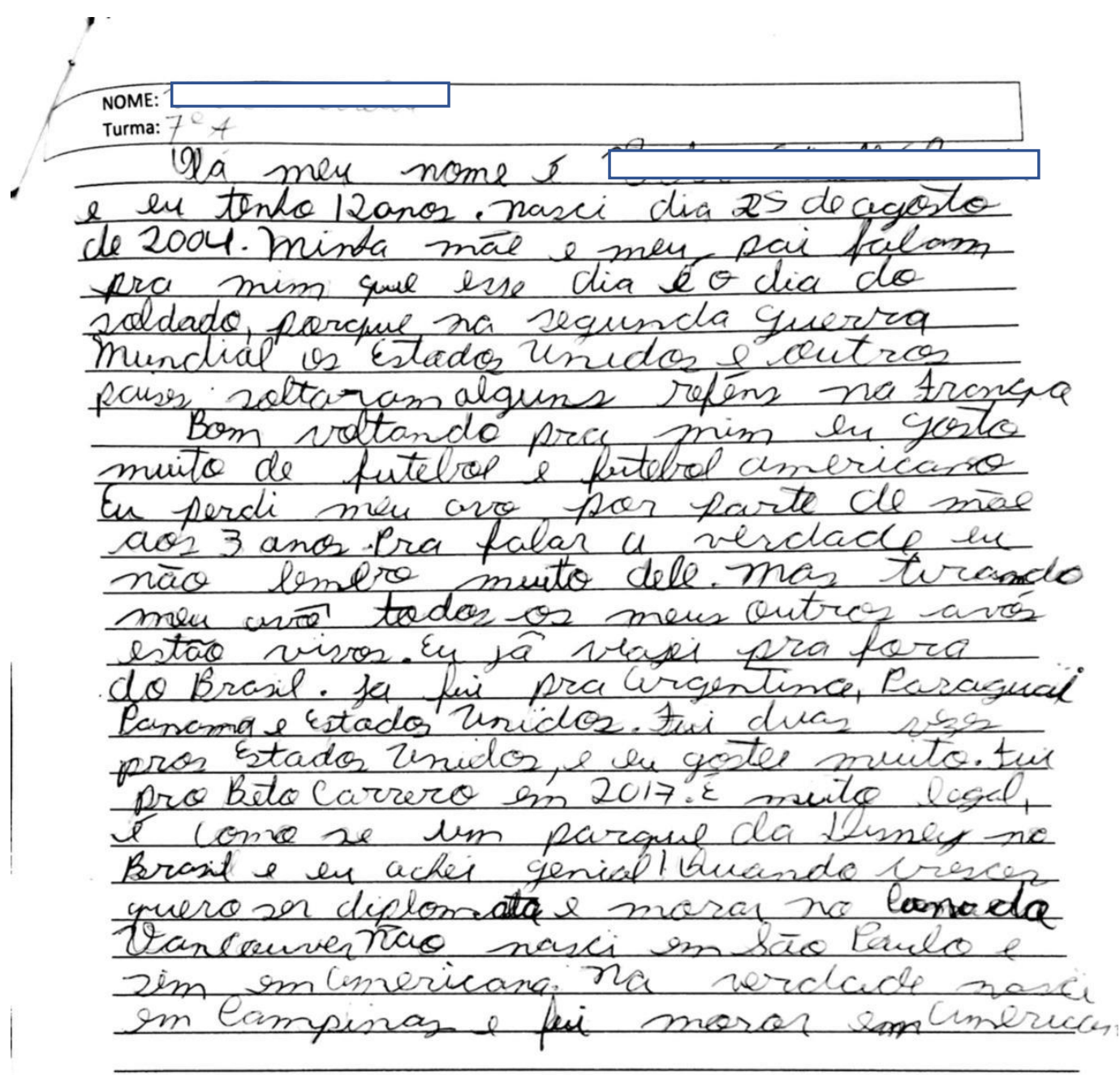

Olá meu nome é V. E. A. e eu tenho 12 anos. Nasci dia 25 de agosto de 2004. Minha mãe e meu pai falam pra mim que esse dia é o dia do soldado, porque na segunda guerra mundial os Estados Unidos e outros paises soltaram alguns reféns na França

Bom voltando pra mim eu gosto muito de futebol e futebol amaericano

Eu perdi meu avo por parte de mãe aos 3 anos. Pra falar a verdade eu não lembro muito dele. Mas tirando meu avô todos os outros meus avós estão vivos. Eu já viajei pra fora do Brasil. ja fui pra Argentina, Paraguai Panama e Estados Unidos. Fui duas vezes pros Estados Unidos, e eu gostei muito. Fui pro Beto Carrero em 2017. É muito legal, é como se um parque da Disney no Brasil e eu achei genial! Quando crescer quero ser diplomata e morar no Canada Vancouver não nasci em São Paulo e sim em americana. Na verdade nasci em Campinas e fui morar em Americana. 
Texto 36

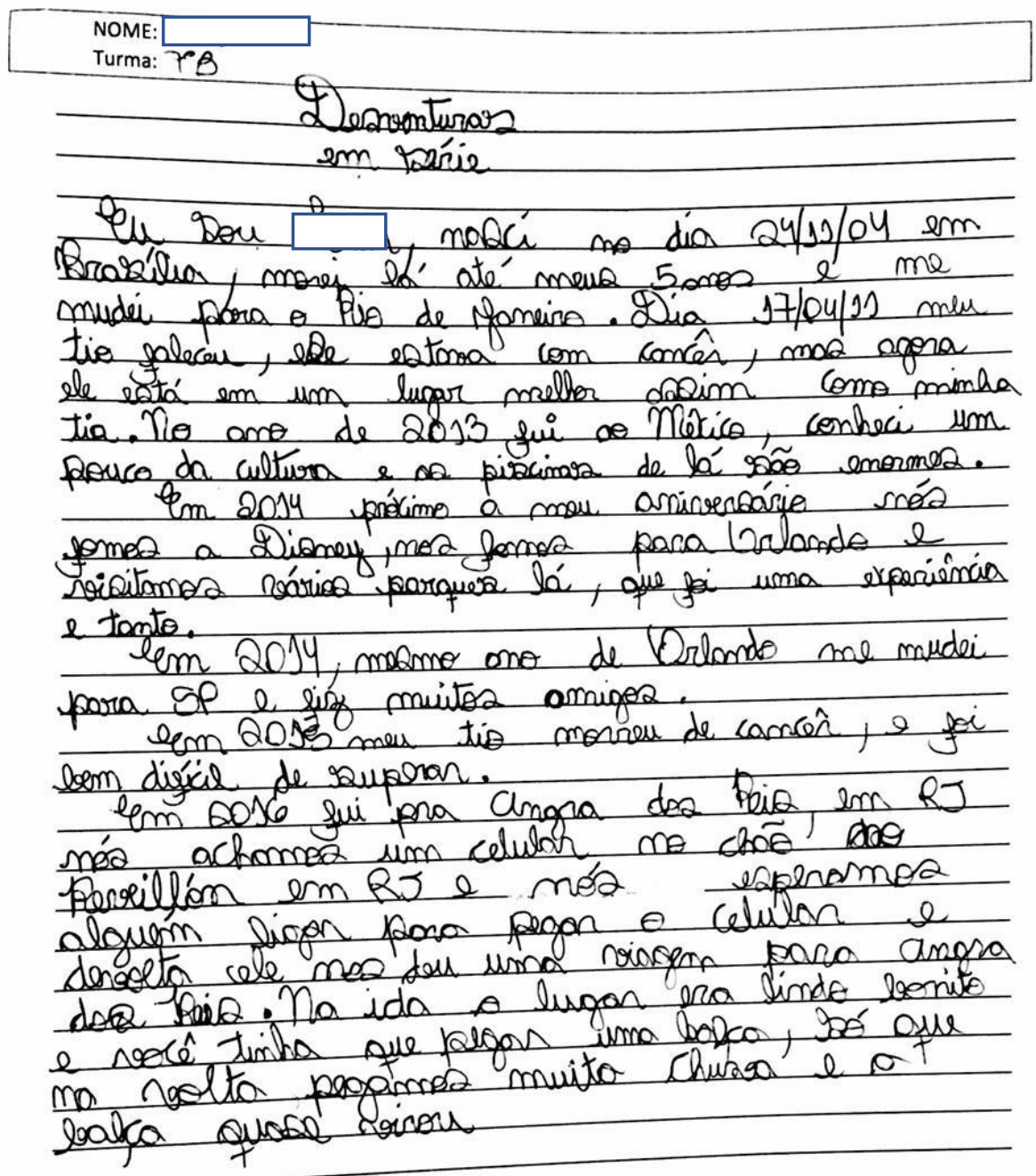

Desventuras em série

Eu sou L., nascí no dia 24/11/2004 em Brasília, morei lá até meus 5 anos e me mudei para o Rio de Janeiro. Dia 17/04/11 meu tio faleceu, ele estava com cancêr, mas agora ele está em um lugar melhor assim como minha tia. No ano de 2013 fui ao México, conheci um pouco da cultura e as piscinas de lá são enormes.

Em 2014 próximo a meu aniversário nos fomos a Disney, nos fomos para Orlando e visitamos vários parques lá, que foi uma experiência e tanto.

Em 2014, mesmo ano de Orlando me mudei para SP e fiz muitos amigos.

Em 2015, o meu tio morreu de cancêr, e foi bem difícil de superar.

Em 2016 fui pra Angra dos Reis, em RJ nós achamos um celular no chão, no Reivellón em RJ e nós esperamos alguém ligar para pegar o celular e de volta ele nos deu uma viagem para Angra dos Reis. Na ida o lugar era lindo bonito e você tinha que pegar uma balça, só que na volta pegamos muita chuva e a balça quase virou. 
Texto 37

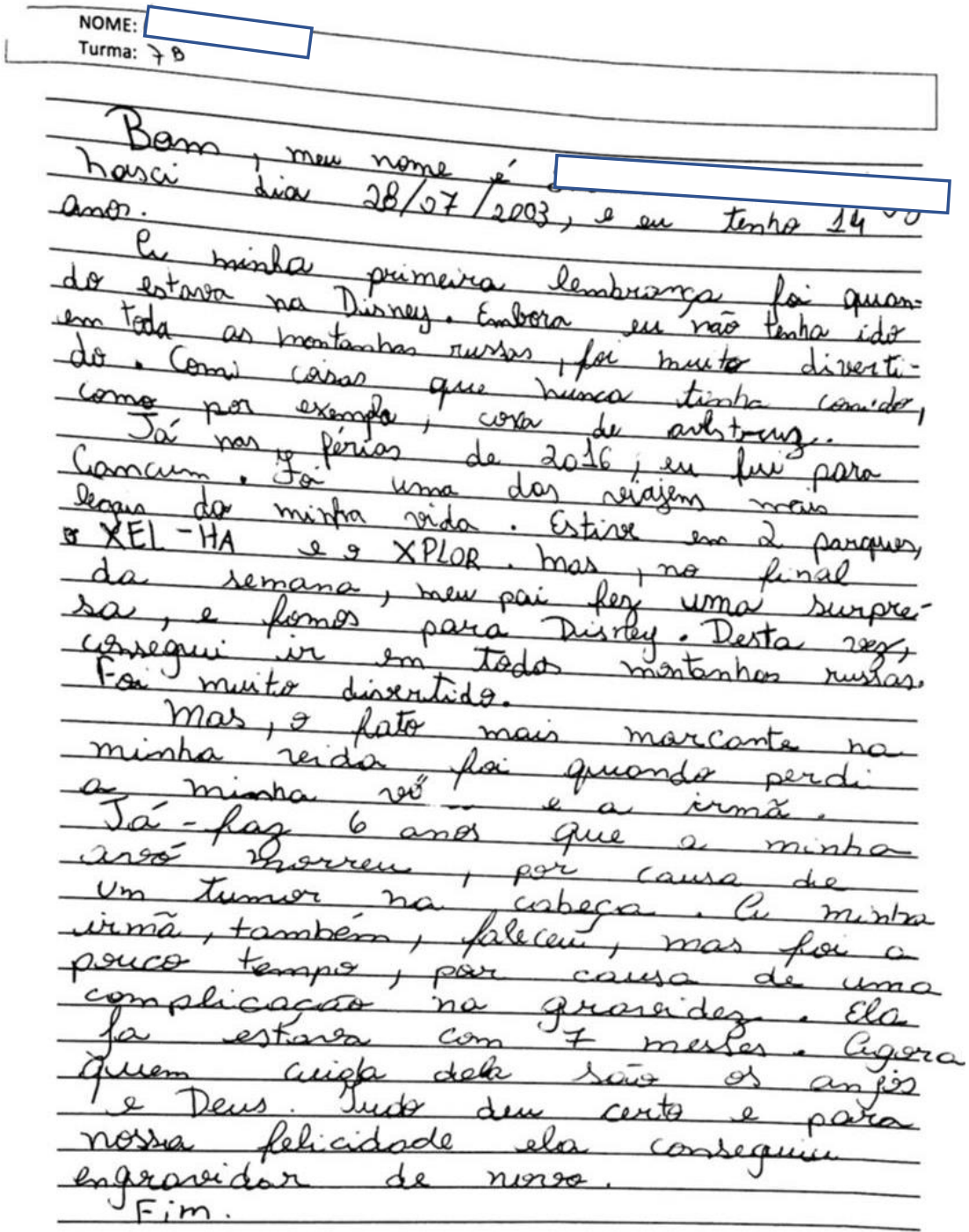

Bom, meu nome é L. M. D., nasci dia 28/07/2003, e eu tenho 14 anos.

A minha primeira lembrança foi quando estava na Disney. Embora e não tenha ido em todas as montanhas russas, foi muito divertido. Comi coisas que nunca tinha comido, como por exemplo, casca de avestruz.

Já nas férias de 2016, eu fui para Cancun. Foi uma das viajens mais legais da minha vida. Estive em 2 parques, o XEL-HA e o XPLOR. mas, no final da semana, meu pai fez uma surpresa, e fomos para Disney. Desta vez, consegui ir todas as montanhas russas.

Foi muito divertido.

mas, o fato mais marcante na minha vida foi quando perdi a minha vó e a irmã. 
Texto 38

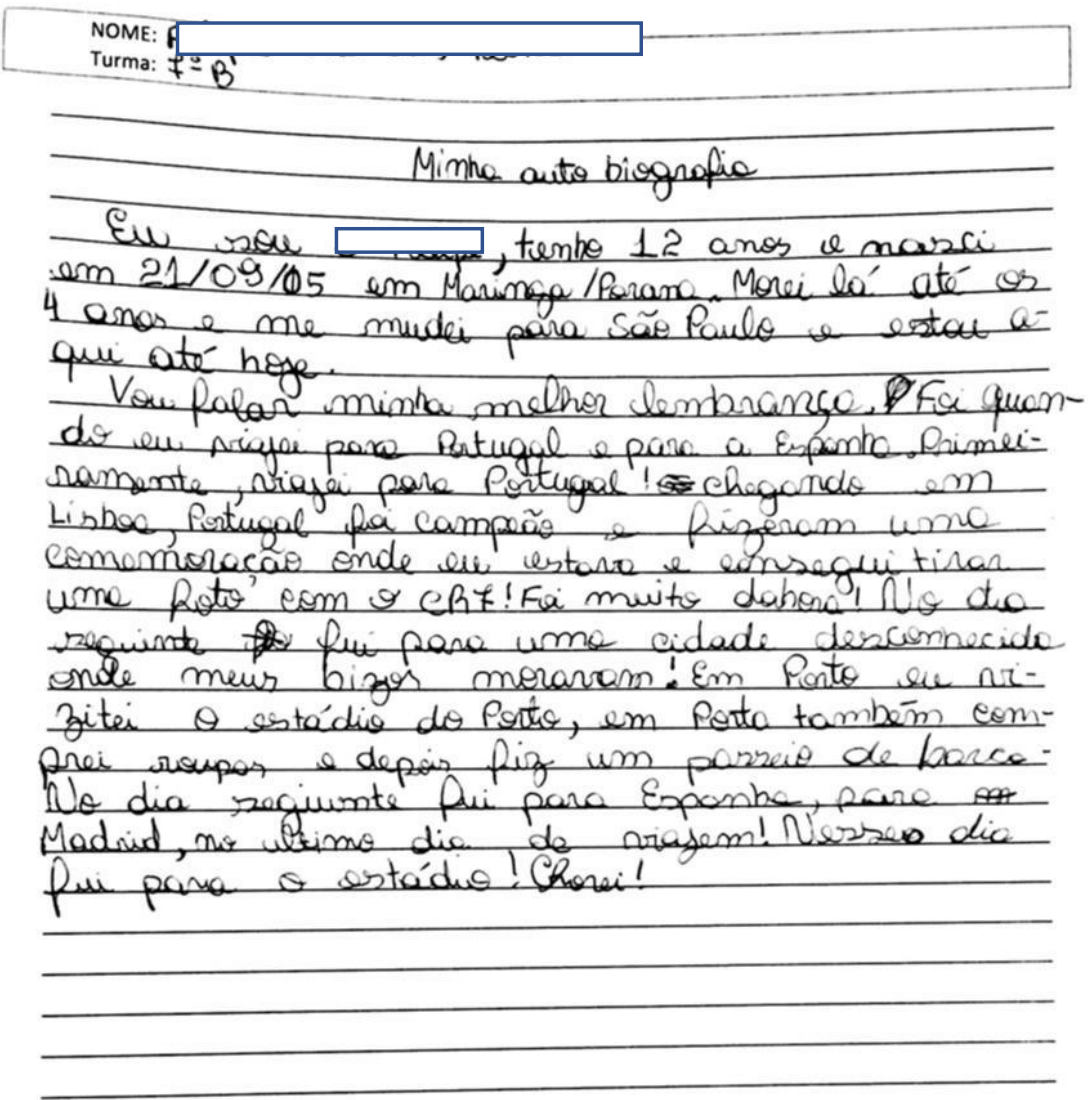

Minha auto biografia

Eu sou o F., tenho 12 anos e nasci em 21/09/05 em Maringa/Parana. Morei lá até os 4 anos e me mudei para São Paulo e estou aqui até hoje.

Vou falar minha melhor lembrança. Foi quando eu viajei para Portugal e para a Espanha. Primeiramente, viajei para Portugal! chegando em Lisboa, Portugal foi campeão e fizeram uma comemoração onde eu estava e consegui tirar uma foto com o CR7! Foi muito dahora! No dia seguinte fui para uma cidade desconhecida onde meus bizos moravam! Em Porto eu vizitei o estádio do Porto, em Porto também comprei roupas e depois fiz um passeio de barco.

No dia seguinte fui para Espanha, para Madrid, no ultimo dia da viajem! Nesse dia fui para o estádio! Chorei! 


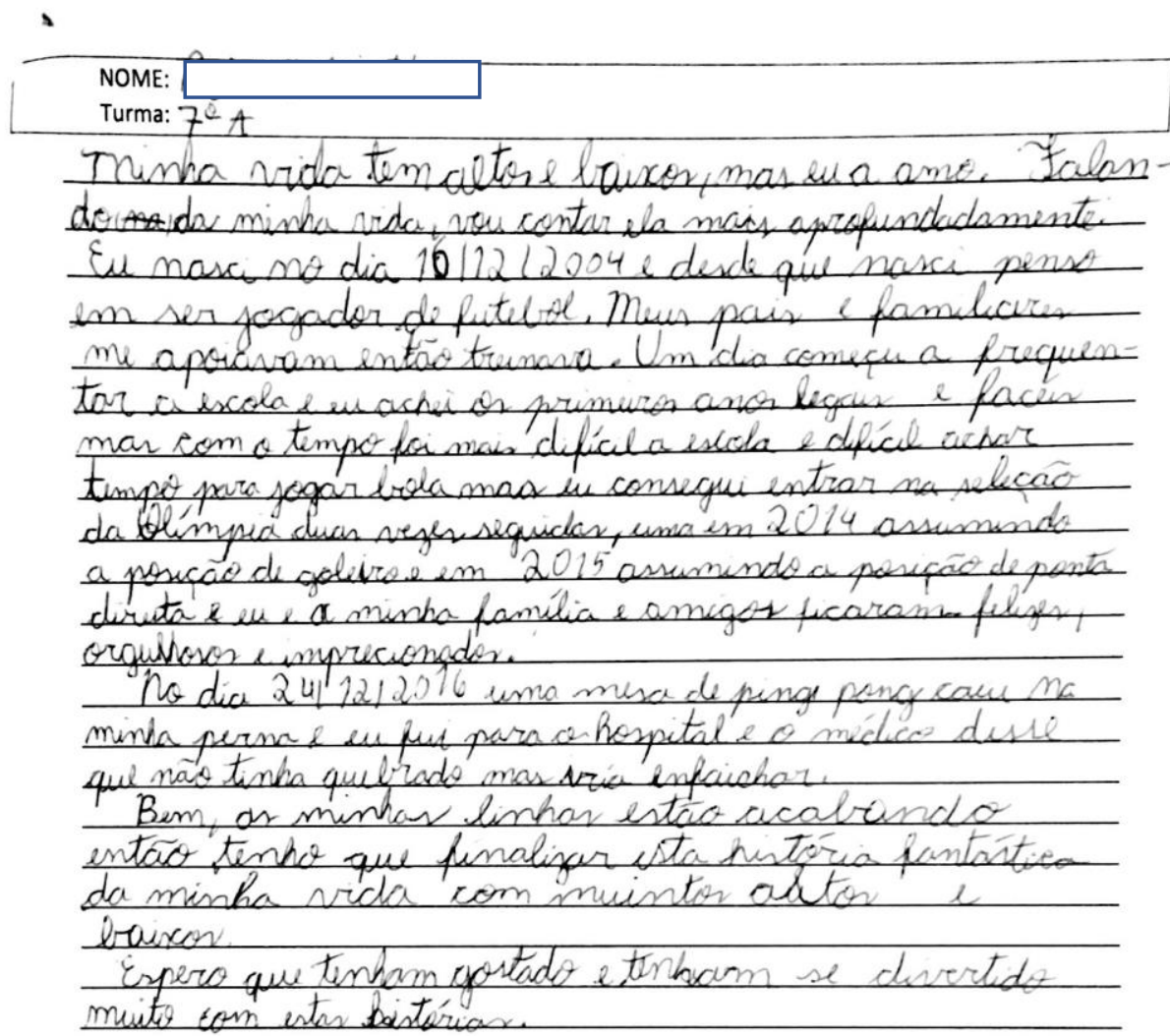

Minha vida tem altos e baixos, mas eu a amo. Falando da minha vida vou contar ela mais aprofundadamente:

Eu nasci no dia 16/12/2004 e desde que nasci penso em ser jogador de futebol. Meus pais e familiares me apoiavam então treinava. Um dia começei a frenquentar a escola e eu achei os primeiros anos legais e fáceis mas com o tempo foi mais difícil achar tempo para jogar bola mas eu consegui entrar na seleção da Olímpia duas vezes seguidas, uma em 2014 assumindo a posição de goleiro e em 2015 assumindo a posição de ponta direita e eu e a minha família e amigos ficaram felizes, orgulhosos e imprecionados.

No dia 24/12/2016 uma mesa de ping pong caiu na minha perna e eu fui para 0 hospital e o médico disse que não tinha quebrado mas iría enfaichar.

Bem, as minhas linhas estão acabando então tenho que finalizar essa história fantástica da minha vida com muitos altos e baixos.

Espero que tenham gostado e se divertido muito com estas histórias. 
Texto 40

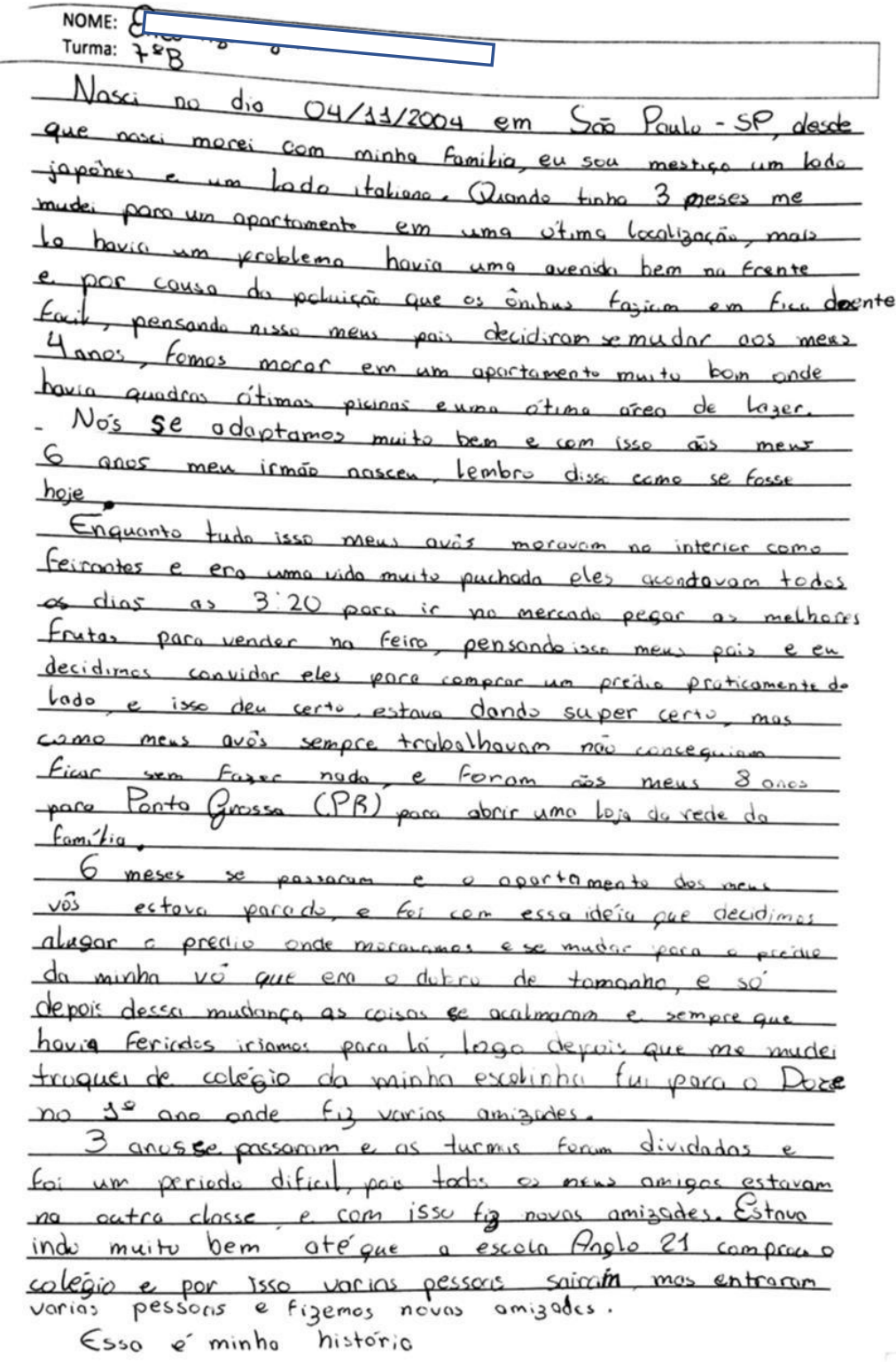

Nasci no dia 04/11/2004 em São Paulo-SP, desde que nasci morei com minha família, eu sou mestiço um lado japonês e um lado italiano. Quando tinha 3 meses me mudei para um apartamento em uma ótima localização, mais la havia um problema havia uma avenida bem na frente e por causa da poluição que os ônibus faziam em fica doente facil, pensando nisso meus pais decidiram se mudar aos meus 4 anos, fomos morar em um apartamento muito bom onde havia quadras ótimas picinas e uma ótima área de lazer.

Nós se adaptamos muito bem e com isso aos meus 6 anos meu irmão nasceu, lembro disso como se fosse hoje. 
Enquanto tudo isso meus avôs moravam no interior como feirantes e era uma vida muito puchada eles acordavam todos os dias as 3:20 para ir no mercado pegar as melhores frutas para vender na feira, pensando isso meus pais e eu decidimos convidar eles para comprar um prédio praticamente do lado, e isso deu certo, estava dando super certo, mas como meus avôs sempre trabalhavam não conseguiam ficar sem fazer nada, e foram aos meus 8 anos para Ponta Grossa (PR) para abrir uma loja de rede da família.

6 meses se passaram e o apartamento dos meus vôs estava parado, e foi com essa idéia que decidimos alugar o predio onde moravamos e se mudar para 0 prédio da minha vó que em o dobro do tamanho, e só depois dessa mudança as coisas se acalmaram e sempre que havia feriados iriamos para lá, logo depois que me mudei troquei de colégio da minha escolinha fui para o Doze no $1^{\circ}$ ano onde fiz varias amizades.

3 anos se passaram e as turmas foram divididas e foi um periodo dificil, pois todos os meus amigos estavam na outra classe e com isso fiz novas amizades. Estava indo muito bem até que a escola Anglo 21 comprou o colégio e por isso varias pessoas sairam, mas entraram novas pessoas e fizemos novas amizades.

Essa é minha história 
Texto 41

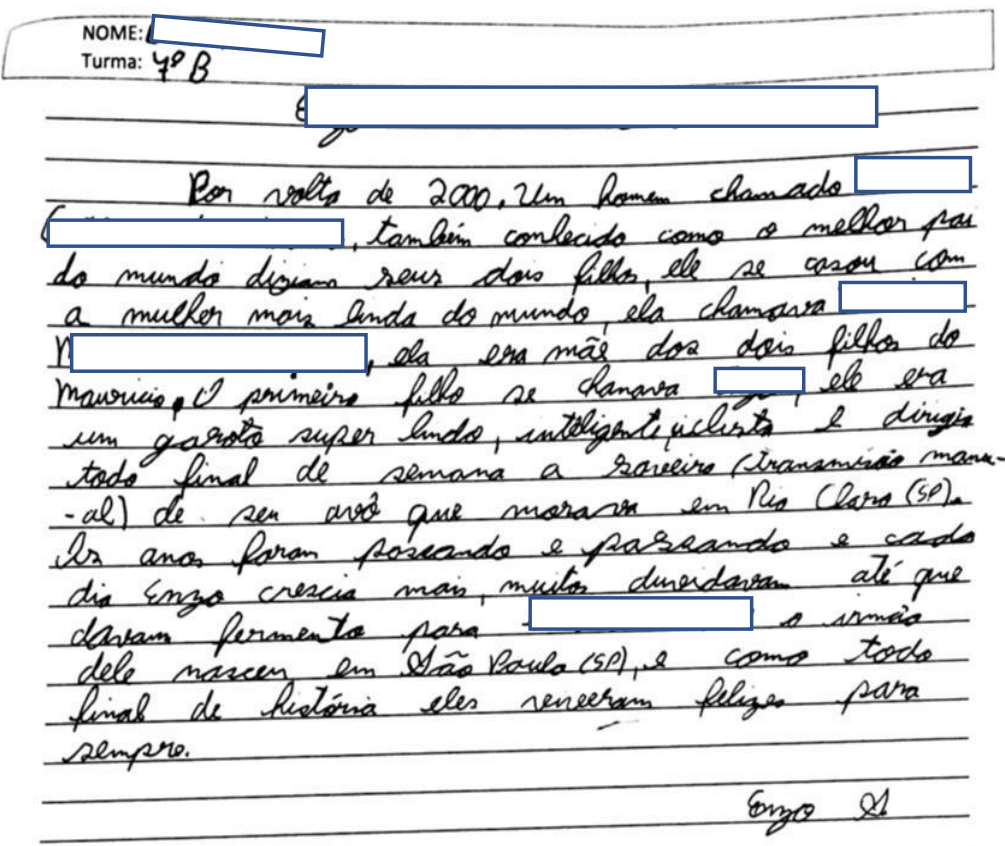

E. M. B. S.

Por volta de 2000. Um homem chamado M. A. S., também conhecido como o melhor pai do mundo diziam seus dois filhos, ele se casou com a mulher mais linda do mundo, ela chamava M. M. B., ela era mãe dos dois filhos do M.. O primeiro filho se chamava E., ele era um garoto super lindo, inteligente, ciclista, e dirigia todo final de semana a saveiro (transmissão manual) de seu avô que morava em Rio Claro (SP).

Os anos foram passando e passando e cada dia E. crescia mais, muitos duvidavam até que davam fermento para ele. Em 2011 o irmão dele nasceu em São Paulo (SP), e como todo final de história eles viveram felizes para sempre.

E. S. 


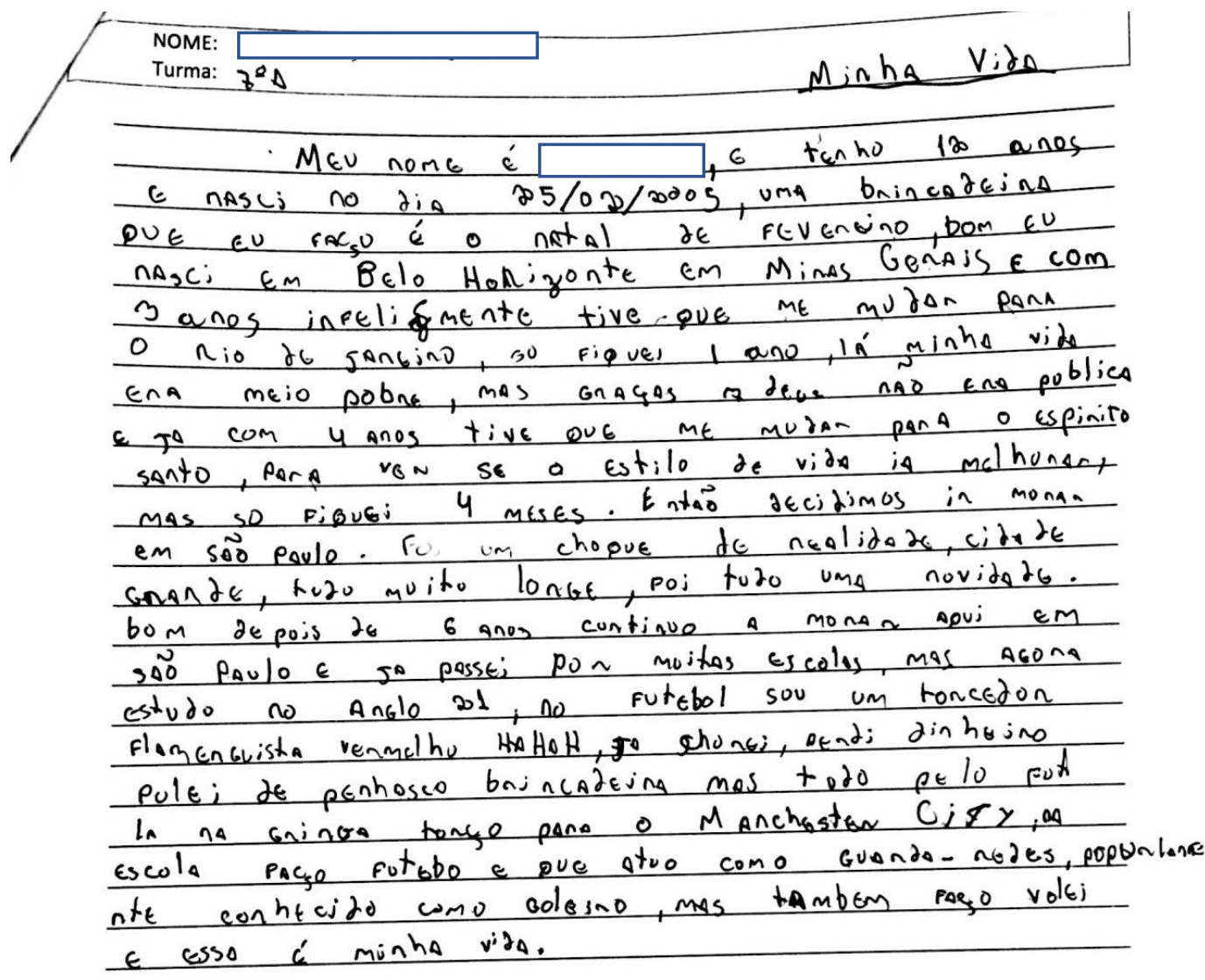

Meu nome é M., e tenho 12 anos e nasci no dia 25/02/2005, uma brincadeira que eu faço é o natal de fevereiro, bom eu nasci em Belo Horizonte em Minas Gerais e com 3 anos infelizmente tive que me mudar para o Rio de Janeiro, só fiquei 1 ano, lá minha vida era meio pobre, mas graças a deus não era publica e com 4 anos tive que me mudar para o Espirito Santo, para ver se o estilo de vida ia melhorar, mas só fiquei 4 mases. Então decidimos ir morar em São Paulo. Foi um choque de realidade, cidade grande, tudo muito longe, foi tudo uma novidade.

bom depois de 6 anos continuo a morar aqui em São Paulo e ja passei por muitas escolas, mas agora estudo no Anglo 21, no futebol sou um torcedor flamenguista vermelho hahah, ja chorei, perdi dinheiro pulei de penhasco brincadeira mas tudo pelo fut la na gringa torço para o Manchester City, na escola faço futebol e que atuo como guarda-redes, popurlamente conhecido como goleiro, mas tambem faço volei e esse é minha vida. 